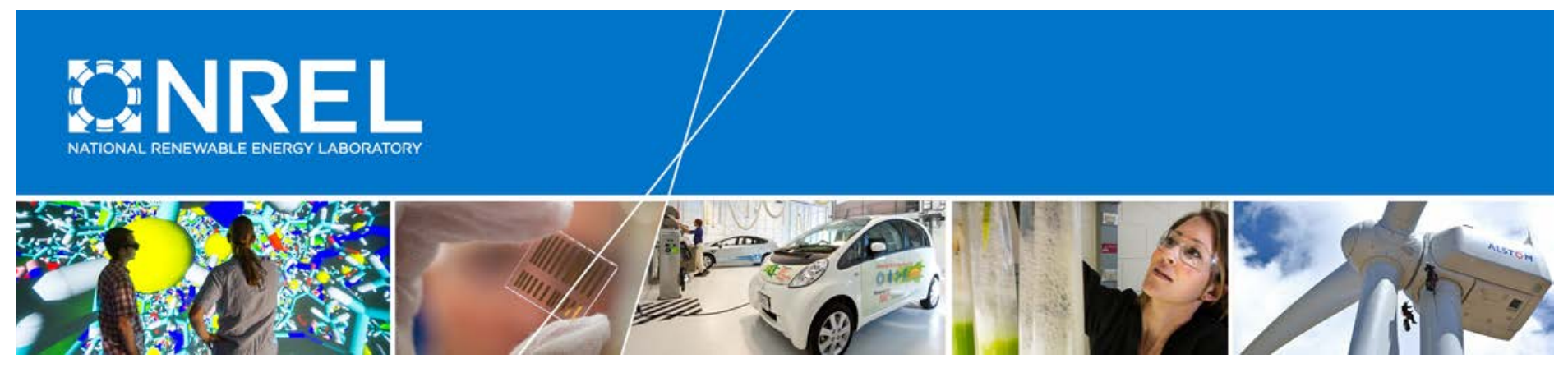

\title{
Vegetation and Wildlife Surveys at the National Renewable Energy Laboratory, National Wind Technology Center
}

\section{July 2010 - May 2011}

Walsh Environmental Scientists and Engineers, LLC Boulder, Colorado

NREL Technical Monitor: Tom Ryon

NREL is a national laboratory of the U.S. Department of Energy Office of Energy Efficiency \& Renewable Energy Operated by the Alliance for Sustainable Energy, LLC

This report is available at no cost from the National Renewable Energy Laboratory (NREL) at www.nrel.gov/publications.

Subcontract Report

NREL/SR-1900-70462

July 2018 


\section{Vegetation and Wildlife Surveys at the National Renewable Energy Laboratory, National Wind Technology Center}

\section{July 2010 - May 2011}

Walsh Environmental Scientists and Engineers, LLC Boulder, Colorado

NREL Technical Monitor: Tom Ryon

Prepared under Subcontract No. LGF-0-40734-01

\section{Suggested Citation}

Walsh Environmental Scientists and Engineers, LLC. 2018. Vegetation and Wildlife Surveys at the National Renewable Energy Laboratory, National Wind Technology Center: July 2010 - May 2011. Golden, CO: National Renewable Energy Laboratory. NREL/SR-1900-70462.

https://www.nrel.gov/docs/fy18osti/70462.pdf.
National Renewable Energy Laboratory 15013 Denver West Parkway Golden, CO 80401

303-275-3000 • www.nrel.gov
NREL is a national laboratory of the U.S. Department of Energy Office of Energy Efficiency \& Renewable Energy Operated by the Alliance for Sustainable Energy, LLC

This report is available at no cost from the National Renewable Energy Laboratory (NREL) at www.nrel.gov/publications.

\section{Subcontract Report}

NREL/SR-1900-70462

July 2018

Contract No. DE-AC36-08G028308 
This publication was reproduced from the best available copy submitted by the subcontractor and received no editorial review at NREL.

\section{NOTICE}

This work was authored by the National Renewable Energy Laboratory, operated by Alliance for Sustainable Energy, LLC, for the U.S. Department of Energy (DOE) under Contract No. DE-AC36-08GO28308. Funding provided by the U.S. Department of Energy Office of Energy Efficiency and Renewable Energy. The views expressed in the article do not necessarily represent the views of the DOE or the U.S. Government.

This report is available at no cost from the National Renewable Energy Laboratory (NREL) at www.nrel.gov/publications.

U.S. Department of Energy (DOE) reports produced after 1991 and a growing number of pre-1991 documents are available free via www.OSTI.gov.

Cover Photos by Dennis Schroeder: (left to right) NREL 26173, NREL 18302, NREL 19758, NREL 29642, NREL 19795.

NREL prints on paper that contains recycled content. 


\title{
2010-2011 Vegetation and Wildlife Surveys at the National Renewable Energy Laboratory, National Wind Technology Center
}

\section{Jefferson County, Colorado}

\author{
July 11, 2011
}

Purchase Order Number 19601000

Technical Monitor: Thomas Ryon

Prepared for

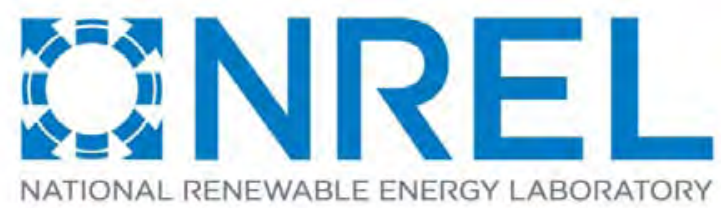

Prepared by

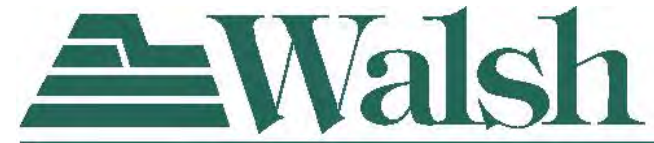

an ecology and environment company 


\section{TABLE OF CONTENTS}

EXECUTIVE SUMMARY ....................................................................................... 1

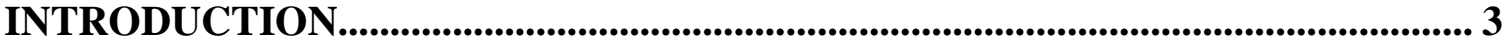

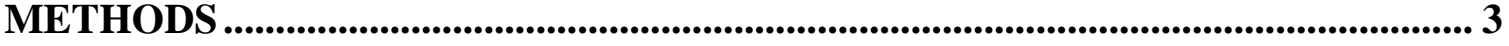

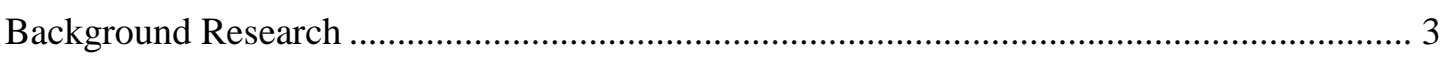

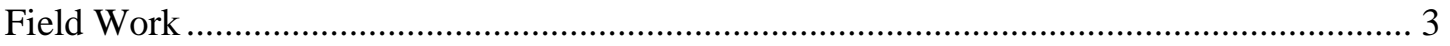

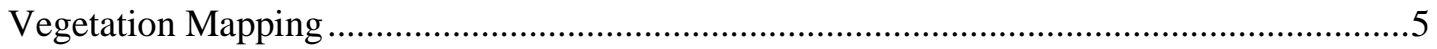

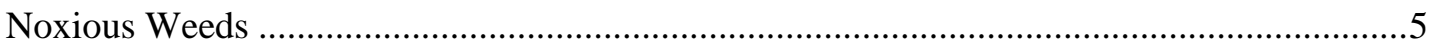

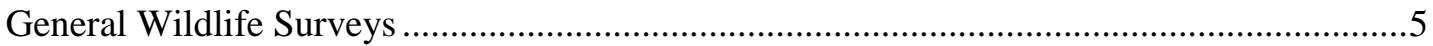

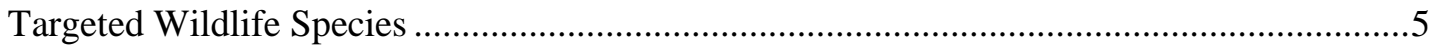

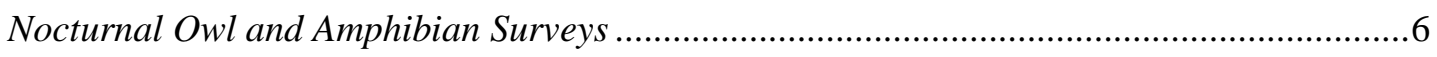

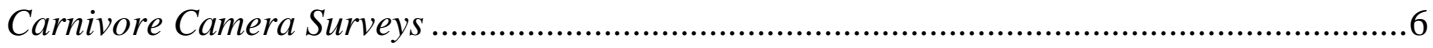

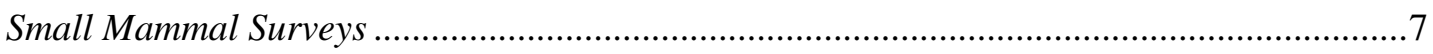

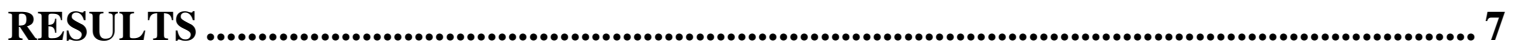

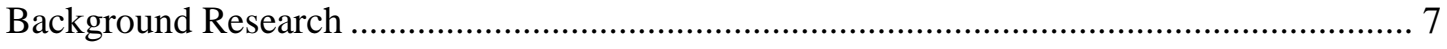

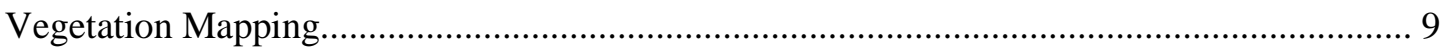

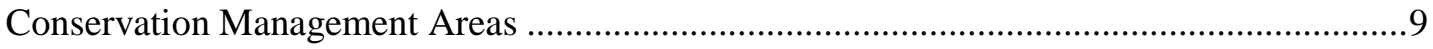

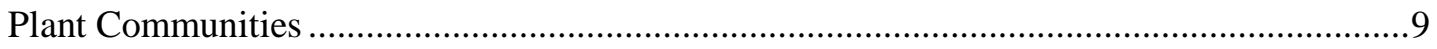

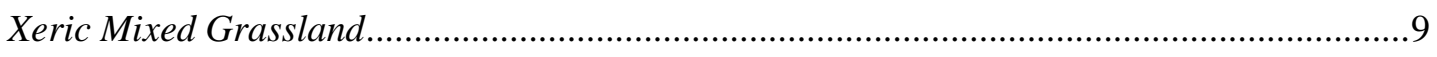

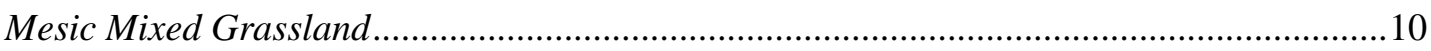

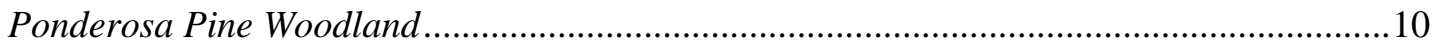

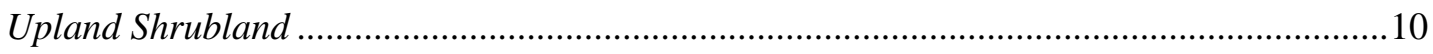

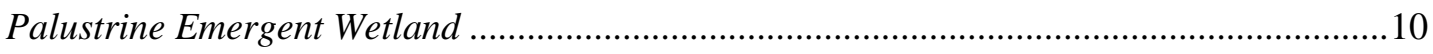

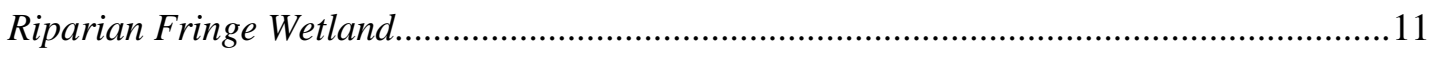

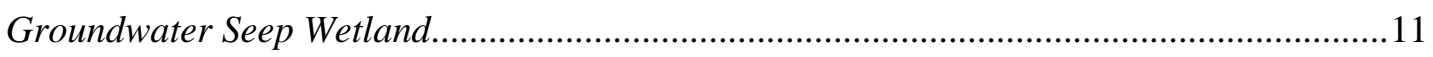

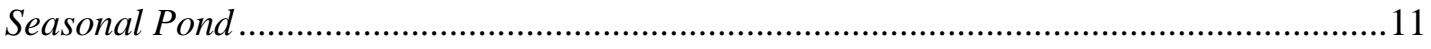

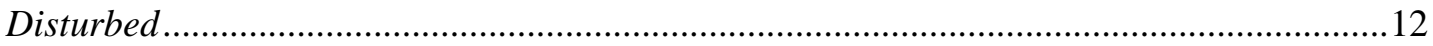

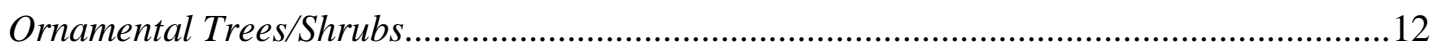

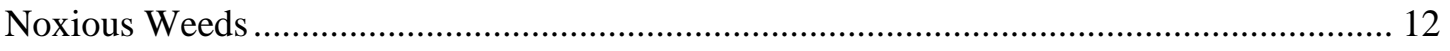

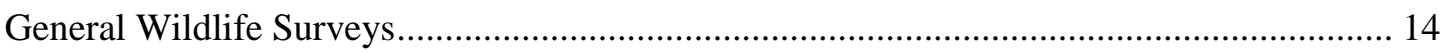

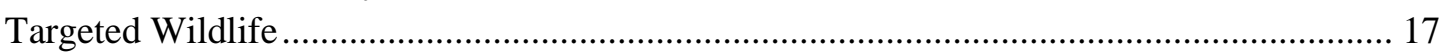

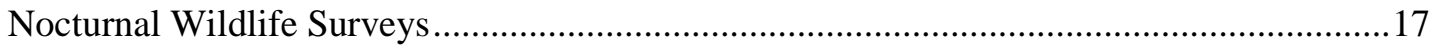

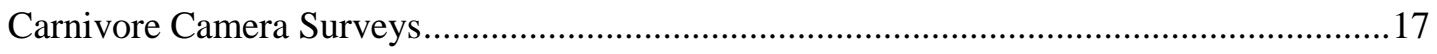

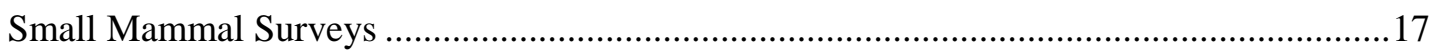

Avian Survey Results from Tetra Tech.................................................................................... 19

DISCUSSION ........................................................................................................................... 19

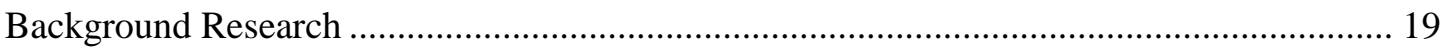

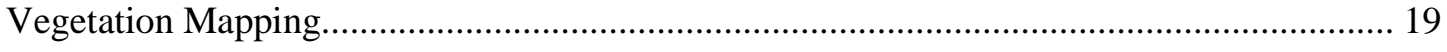

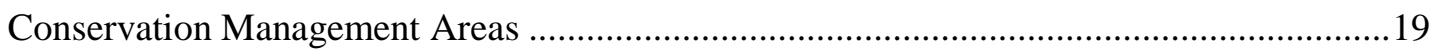


Plant Communities 19

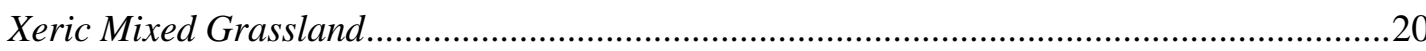

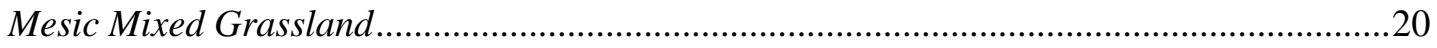

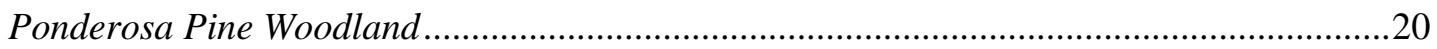

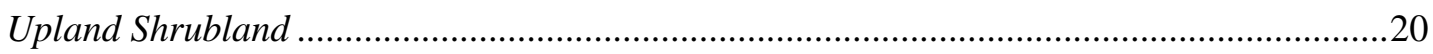

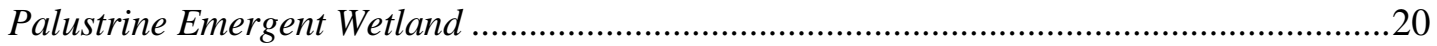

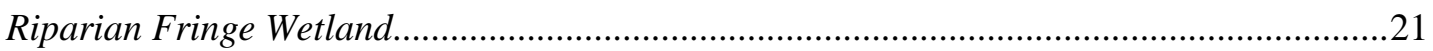

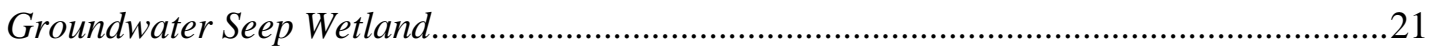

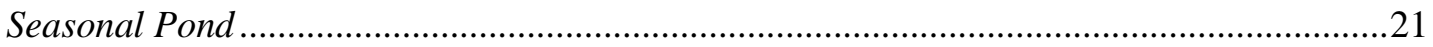

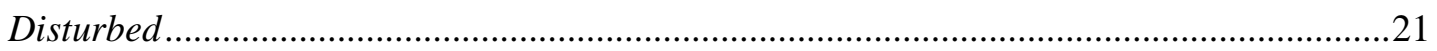

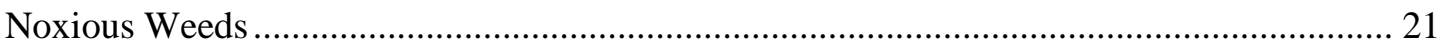

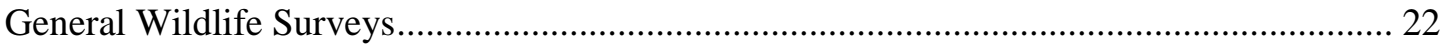

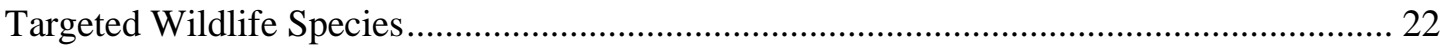

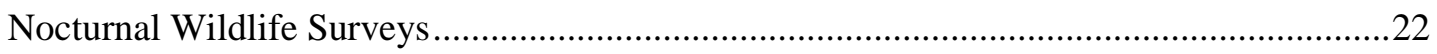

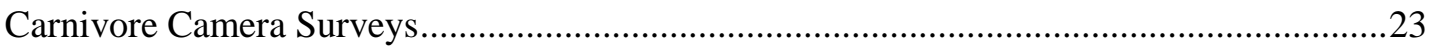

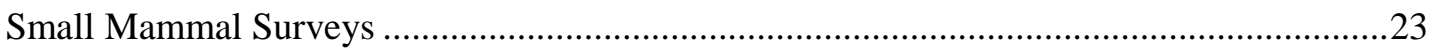

RECOMMENDATIONS................................................................................... 24

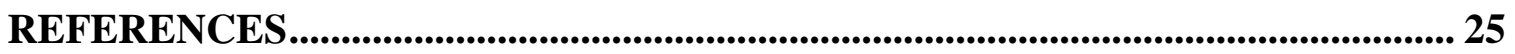

\section{TABLES}

Table 1. Summary of CNHP Rare and/or Imperiled Species and Natural Communities Known From or Likely to Occur Within a Two-mile Radius of NREL's National Wind Technology Center

Table 2. Noxious Weed Species Identified at the National Wind Technology Center, Colorado August, 2010.

Table 3. General Wildlife Observations at the National Renewable Energy Laboratory National Wind Technology Center, 2010 - 2011 .................................................................... 14

Table 4. Small Mammal Captures at the National Wind Technology Center, 2010 and 2011..... 18

\section{FIGURES}

Figure 1. Vegetation Mapping at the National Renewable Energy Laboratory, National Wind

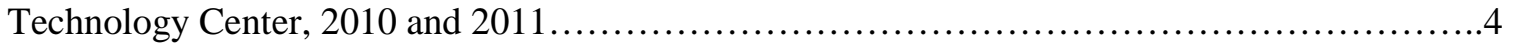

Figure 2. Weed Mapping at the National Renewable Energy Laboratory, National Wind

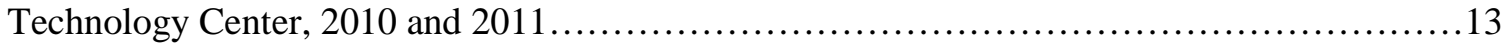

Figure 3. Amphibian Call, Owl, Carnivore Camera, and Small Mammal Trapping Points and Transects at the National Renewable Energy Laboratory, National Wind Technology Center, 2010 and 2011. 


\section{APPENDICES}

Appendix A Colorado Natural Heritage Program Data Query Response

Appendix B Plant Community Species List Tables

Appendix C Plant Community and Other Photos

Appendix D Listing of Mammals, Reptiles, Amphibians, and Terrestrial Arthropods Observed During All Surveys Combined

Appendix E Bat Acoustical Surveys at the National Renewable Energy Laboratory, National Wind Technology Center, Jefferson County, Colorado, May 6, 2011 


\section{LIST OF ACRONYMS}

$\begin{array}{ll}\text { ABPP } & \text { Avian and Bat Protection Plan } \\ \text { CDOW } & \text { Colorado Division of Wildlife } \\ \text { CNHP } & \text { Colorado Natural Heritage Program } \\ \text { DOE } & \text { U.S. Department of Energy } \\ \text { EA } & \text { Environmental Assessment } \\ \text { EERE } & \text { Energy Efficiency and Renewable Energy } \\ \text { EO } & \text { Executive Order } \\ \text { GIS } & \text { Geographic Information Systems } \\ \text { GPS } & \text { Global Positioning System } \\ \text { NEPA } & \text { National Environmental Policy Act } \\ \text { NREL } & \text { National Renewable Energy Laboratory } \\ \text { NWTC } & \text { National Wind Technology Center } \\ \text { RFETS } & \text { Rocky Flats Environmental Technology Site } \\ \text { RMRS } & \text { Rocky Mountain Remediation Services } \\ \text { USFWS } & \text { U.S. Fish and Wildlife Service } \\ \text { Walsh } & \text { Walsh Environmental Scientists and Engineers, LLC }\end{array}$




\section{EXECUTIVE SUMMARY}

The primary objective of this year-long study was to update the National Wind Technology Center (NWTC) vegetation and wildlife baseline conditions, excluding avian species. These baseline conditions will be used to support future National Environmental Policy Act (NEPA) analyses. NWTC is located in northern Jefferson County and is a laboratory center of the National Renewable Energy Laboratory (NREL), a national laboratory of the U.S. Department of Energy (DOE), Office of Energy Efficiency and Renewable Energy, and operated by the Alliance for Sustainable Energy, LLC.

NREL has been conducting vegetation and wildlife surveys at NWTC since 1996. Prior to the current study, Plantae (2000) completed a site characterization of vegetation communities and noxious weeds, Monahan (1996) conducted a raptor study, and Schmidt et al. (2003) conducted a bird and bat use and fatality study.

Concurrent with this study, Tetra Tech, Inc. is completing avian and mortality surveys. For this reason, the present report contains no avian observations. Walsh Environmental Scientists and Engineers, LLC (Walsh) conducted a separate bat study and report (Appendix E).

Background research methods included a review of prior studies conducted at NWTC and a review of species tracked by the Colorado Natural Heritage Program (CNHP), specific to the NWTC area. Field methods included walking transects for mapping of vegetation communities and noxious weeds and observations for general wildlife occurrences throughout the site (mammals, herpetofauna, and invertebrates) during four seasons. Several targeted surveys for wildlife were conducted including: nocturnal playback surveys for owls, amphibian call surveys, motion-detection cameras for mammalian carnivores, and small mammal live trapping.

The CNHP query revealed a number of imperiled species; however, none of these were observed during the yearlong surveys. The majority of vegetation at NWTC belongs to the mixed-grass prairie association of the grassland formation. Within that association, the largest and most widespread community type is the xeric mixed grassland, with a small area of mesic mixed grassland. Other mapped vegetation communities at NWTC include ponderosa pine woodland, upland shrubland, palustrine emergent wetland, riparian fringe wetland, groundwater seep wetland, seasonal pond, disturbed, and ornamental trees/shrubs. Noxious weeds were identified and mapped.

General wildlife surveys found species characteristic of the habitats onsite. Mammal observations included mule deer (Odocoileus hemionus), American elk (Cervus elaphus), and desert cottontail (Sylvilagus audubonii). Coyote sign (scat) was observed. Herpetofauna observations included two amphibian species: boreal chorus frog (Pseudacris maculata) and Woodhouse's toad (Bufo woodhousii). Invertebrates observed were commonly occurring species of several genera.

Playback surveys for owl species detected only great horned owl (Bubo virginianus). During amphibian call surveys, a boreal chorus frog was detected; additional individuals were detected beyond the boundaries of NWTC. No carnivores were recorded using the motion-detecting monitors. Small mammal trapping resulted in a high species richness with six species captured onsite over two survey periods. The capture rate was also high, at 15 percent.

Significant findings of this study include:

- $\quad$ Since the site was last mapped (DOE 1998, Plantae 2000), some observed trends in vegetation patterns include a general increase in invasive and noxious weed species 
diversity and coverage throughout the various plant communities as well as a shift in native species composition to include more upland species and fewer species with a wetland indicator status of facultative or wetter. Some possible factors that may be contributing to these apparent trends could include general drying of soils as well as changes in land use since 2000.

- The NWTC site contains 12 plant species found on the State of Colorado Noxious Weed List.

- No detections of regionally important Special Status Species (mammals or invertebrates) as defined by Colorado Division of Wildlife (CDOW), U.S. Fish and Wildlife Service (USFWS) and CNHP.

- Wildlife surveys detected common genera and species expected for the habitats and region of NWTC. In addition, four species were added to the list of species previously documented onsite: boreal chorus frog, Woodhouse's toad, masked shrew, western harvest mouse, meadow vole, and American elk.

- High species richness for small mammals indicates that the site has high biodiversity value, especially for small mammals and their predators. 


\section{INTRODUCTION}

This year-long wildlife and vegetation study was conducted to update the National Wind Technology Center (NWTC) vegetation and wildlife baseline conditions. These updated baseline conditions will be used to support future National Environmental Policy Act (NEPA) analyses. NWTC is a laboratory center of the National Renewable Energy Laboratory (NREL), a national laboratory of the U.S. Department of Energy (DOE), Office of Energy Efficiency and Renewable Energy, and operated by the Alliance for Sustainable Energy, LLC.

NWTC is located on approximately 305 acres in Jefferson County, Colorado, south of State Highway 128 and east of State Highway 93, between the cities of Boulder and Golden. The legal description of the property area is: T2S, R70W, portions of Sections 3 and 4 (Figure 1).

NREL has been conducting vegetation and wildlife surveys at NWTC since 1996. Prior to the current study, Plantae (2000) completed a site characterization of vegetation communities and noxious weeds, Monahan (1996) conducted a raptor study, and Schmidt et al. (2003) conducted a bird and bat use and fatality study. More recently, Walsh conducted a bat study in 2010 (see Appendices).

The current effort involved conducting four seasons of vegetation and wildlife surveys beginning in July 2010 and ending in May 2011. This report presents the results of these surveys.

Concurrent avian monitoring studies by Tetra Tech, Inc. were conducted beginning January 2010 to September 2011. The results of these surveys are presented in a separate report.

\section{METHODS}

\section{Background Research}

Walsh compiled past wildlife and vegetation surveys conducted on the NWTC site (Plantae Consulting Services, 2000; Schmidt et al., 2003; Rocky Mountain Remediation Services, 1998; and Monahan, 1996). In order to support the most efficient comparison of current data with the previous studies, methods from these previous surveys were integrated into the current effort.

The Site-Wide Environmental Assessment (EA) of National Renewable Energy Laboratory's National Wind Technology Center (DOE 2002) was reviewed as part of the background research of wildlife occurrences on NWTC.

A query was submitted to the CNHP of Colorado State University for known locations of rare and/or imperiled plant and animal species and terrestrial arthropods specific to genera of concern within and up to a two-mile radius of the NWTC. For this project, Special Status Species are defined as those species listed by the Colorado Division of Wildlife (CDOW 2010) and the U.S. Fish and Wildlife Service (USFWS 2010) as Threatened, Endangered, Candidate, Proposed, or Species of Special Concern.

\section{Field Work}

For this project the seasons are as follows: summer (May, June and July), fall (August, September, and November), winter (December, January, and February), and spring (March, April and May). This was to provide continuity with other NREL studies and other similar surveys conducted at NREL's South Table Mountain site in Golden, Colorado. 


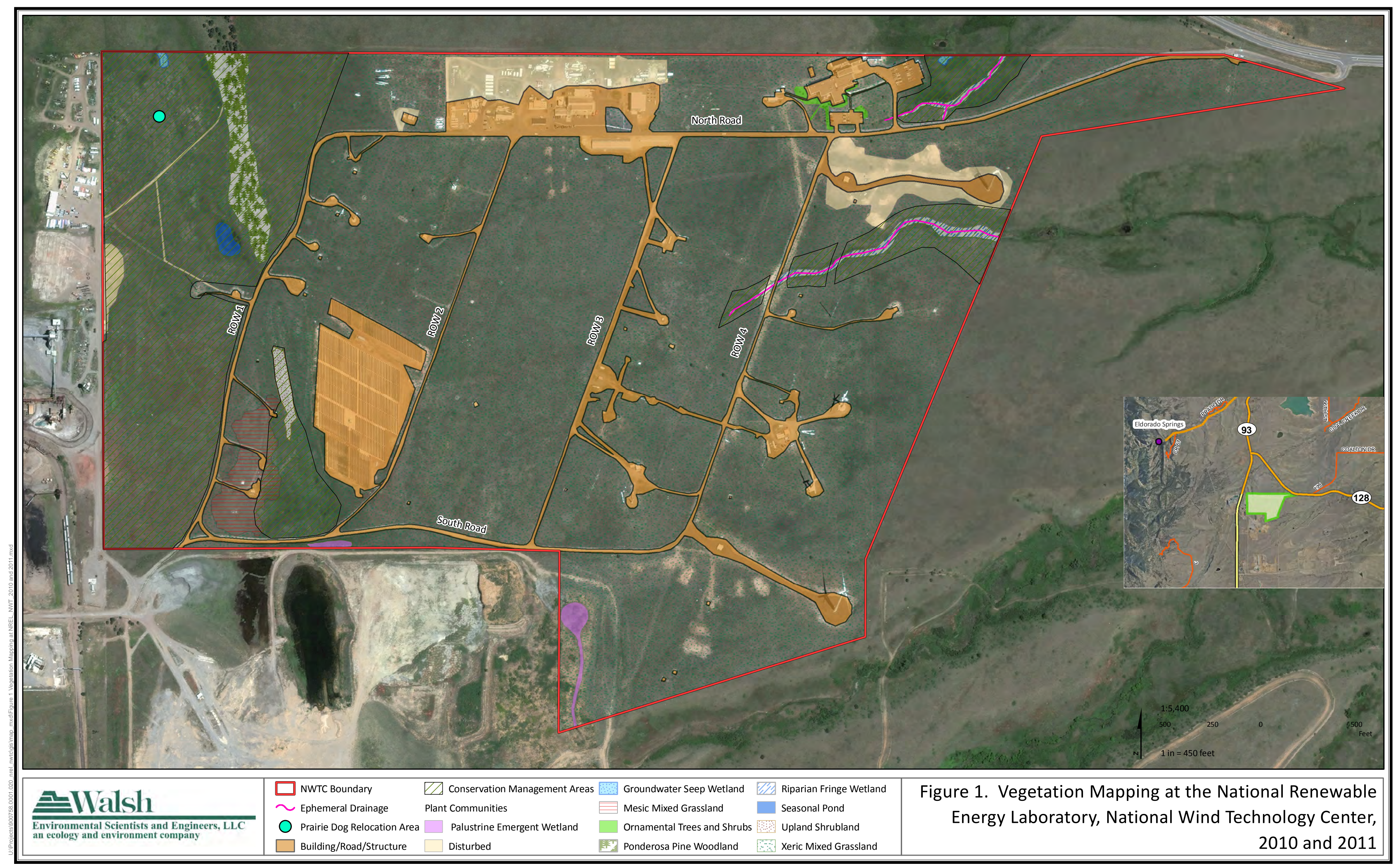




\section{Vegetation Mapping}

Vegetation mapping and characterization were performed following methods described in Plantae (2000). Major plant communities were the basis for both efforts. For the current effort, the previously characterized location and area of all major plant communities on the site were checked against current rectified aerial photography and ground-truthed in the field on August 4 and 5, October 13, 19, and 21, 2010; and May 6 and 9, 2011.

During the ground-truthing effort, transects were walked at variable intervals through each previously-mapped community. In smaller communities with general linear configurations, including the upland shrubland, the ponderosa pine woodland, and the riparian fringe wetland communities, transects were walked from one end of the community to the other. Short parallel transects were then walked back and forth across the community, perpendicular to the long transect. General conditions such as the location each community and visual estimates of dominant and flowering species for each community type were recorded. Comprehensive plant species lists for each community were updated, as necessary. Observations of on-the-ground discrepancies found between the previous mapping effort and current conditions were noted using visual estimation. Representative photographs of all plant communities were collected. Plant taxonomic authority follows Weber and Wittmann (2001).

In the more extensive plant communities, including the xeric mixed grassland and developed areas, parallel transects were walked through different portions of each community. In the xeric mixed grassland, parallel transects were walked through a portion of the site west of Row 1 , between Rows 1 and 2, between Rows 2 and 3, between Rows 3 and 4, east of Rows 4, in the northern portion of the project area both west and east of the buildings, and in the south portion of the project area, on either side of the south road (Figure 1).

\section{Noxious Weeds}

The location of weed populations defined by the Colorado Noxious Weed List (CDOA 2010) was assessed by walking transects across the site in August 2010. Populations of weeds that occurred in a diffuse pattern with individual or small numbers of plants scattered throughout the landscape were noted but not mapped as distinct polygons. Weed populations with a high density of plants per square meter were mapped as such. Digital location data were collected using Global Positioning System (GPS) receiver units and downloaded into a Geographic Information System (GIS) database. These data were used to estimate weed population size.

\section{General Wildlife Surveys}

General wildlife surveys were conducted in each season, concurrent with other surveys, as appropriate. These surveys included site-wide observations for large mammals, mammalian predators, reptiles and amphibians, and terrestrial arthropods specific to genera of concern as found in the CHNP query response (Appendix A) in appropriate habitats. In addition, any Special Status wildlife species observed were recorded. All wildlife observations were identified to species and locations were documented as GPS points. Habitat associations for wildlife are matched to the vegetation mapping.

\section{Targeted Wildlife Species}

Targeted wildlife species surveys were conducted in addition to the general surveys described above. Targeted wildlife surveys included nocturnal surveys for owls and amphibians, carnivore camera surveys, and small mammal trapping surveys. In addition, any Special Status species observed were recorded. 


\section{Nocturnal Owl and Amphibian Surveys}

Nocturnal playback surveys were conducted for owl species with a possibility to occur at NWTC: northern saw-whet owl (Aegolius acadicus) and northern pygmy-owl (Glaucidium gnoma). Surveys were conducted using a protocol adapted from the U.S. Forest Service (Francis \& Bradstreet 1997). The timing of these surveys corresponds to the regional peak period of calling activity for breeding nocturnal owls. Surveys were conducted at a series of three points along a predetermined route. Points were selected to maximize the potential for detection of owls and efficiently survey NWTC. Two playback stations were located in the western portion of the site in the ponderosa pine (Pinus ponderosa) woodland located in the western portion of the site. A third point was added at the recommendation of NREL staff in an area where a third owl species, great horned owl (Bubo virginianus), had been observed. This was located just east of the intersection of Row 4 and the road along the southern boundary of the site. Great horned owls were noted whenever they were observed. One species, eastern screech-owl (Megascops asio), was not included in surveys as its preferred breeding habitat plains cottonwood (Populus tremuloides) riparian woodland does not occur on NWTC.

Playback/response surveys were conducted on February 7 and 18. Playback/response involved playing 30 seconds of a recorded call of a single species followed by 30 second intervals of listening for a response. This pattern was repeated for five minutes for northern saw-whet owl, followed by five minutes of the same pattern for the northern pygmy-owl, for an overall total of 10 minutes of playback/response at each sample point.

Walsh conducted acoustical surveys for bats. Details of the methods and results of this work are presented in a separate report titled Bat Acoustical Surveys at the National Renewable Energy Laboratory, National Wind Technology Center, Jefferson County, Colorado, May 6, 2011 (Appendix E).

Amphibian call surveys occurred on May 3, 4, and June 2, 2011. Seven predetermined survey points were visited near wetland areas, 30 to 60 minutes after sunset. Points were selected to maximize the potential for detection of amphibians (wetlands and seasonal ponds) and efficiently survey NWTC. After arrival at a survey point, surveyors waited quietly for one minute, then began a five-minute listening period. The observers documented each species heard vocalizing and recorded a calling index value adapted for use across North America following a U.S. Geological Survey protocol (Droege 2010): $0=$ no frogs, of a given species, can be heard calling; 1 = individual calls, not overlapping; 2 = calls are overlapping; but individuals are still distinguishable; 3 = numerous frogs can be heard; chorus is constant and overlapping.

\section{Carnivore Camera Surveys}

Walsh used five motion-detecting camera setups for the carnivore camera surveys (Trailmaster ${ }^{\mathrm{TM}}$ monitors with connected film cameras). The monitors are passive sensing units that detect infrared waves and motion. Monitors recorded all interruption incidents of a cone-shaped beam to trigger the cameras. Surveys occurred for a total of five days (four consecutive nights) during each of the four seasons: July (summer), August (fall), November (winter), and February (spring). One roll of 24 exposure film was used per camera for each season of deployment. Five survey locations were selected based on potential carnivore use areas as evaluated by topography, tracks observed, vegetation, and staff knowledge as well as minimal disruption to/from NTWC research activities. The equipment was attached to existing metal T-posts and trees using straps and clamps and each camera was baited with a Scented Predator Survey Disk (USDA Pocatello Supply Depot 2010). Camera film was developed to assess what animals, including carnivores, 
were photographed on the site. The camera sites were checked for tracks once each season when the cameras were taken down.

\section{Small Mammal Surveys}

Walsh conducted small mammal trapping along six transects in three vegetation communities: one in xeric mixed grassland/Ponderosa pine woodland, three in xeric mixed grassland, and two in riparian fringe wetland. Two small mammal live-trapping surveys occurred, one August 24 to 26, 2010, and another May 2 to 5, 2011. Each survey took place over three consecutive nights. Two-hundred and fifty Sherman live traps were placed five meters apart along the transects, resulting in a total of 750 trap nights for each survey.

The protocol employed standard field procedures for small mammal trapping and followed the guidelines approved by the Animal Care and Use Committee of the American Society of Mammalogists (Sikes et al. 2011). Traps were baited with sweet horse feed, and a ball of polyester batting was placed inside each trap for insulation and bedding to prevent hypothermia.

The species, sex, and age of each trapped animal was determined and recorded each morning. The animals were released at the trap station, and the traps were closed and then reopened late in the day. Traps were washed at the end of the trapping session in a 10 percent bleach solution to prevent transmission of hantavirus.

Data from the small mammal trapping were entered into an Excel spreadsheet. Quality assurance/quality control was conducted by cross-referencing the Excel spreadsheet with the original data sheets.

\section{RESULTS}

\section{Background Research}

The results of the CNHP database query for the NWTC site indicate that it is located within the Rocky Flats Grassland Network of Conservation Areas (NCA) and the southeast portion of the site is located within the Rocky Flats Potential Conservation Area (PCA). Table 1 summarizes the results of the CNHP species and natural community query for NWTC (Appendix A).

Table 1. Summary of CNHP Rare and/or Imperiled Species and Natural Communities Known From or Likely to Occur Within a Two-mile Radius of NREL's National Wind Technology Center

\begin{tabular}{|l|l|}
\hline \multicolumn{1}{|c|}{ Common Name } & \multicolumn{1}{c|}{ Mcientific Name } \\
\hline Black-tailed prairie dog & Cynomys ludovicianus \\
\hline Meadow jumping mouse subsp. & Zapus hudsonius preblei \\
\hline \multicolumn{2}{|c|}{ Birds } \\
\hline Ferruginous hawk & Buteo regalis \\
\hline Bald eagle & Haliaeetus leucocephalus \\
\hline Lewis's woodpecker & Melanerpes lewis \\
\hline \multicolumn{2}{|c|}{ Insects } \\
\hline Arogos skipper & Atrytone arogos \\
\hline
\end{tabular}


Table 1. Summary of CNHP Rare and/or Imperiled Species and Natural Communities Known From or Likely to Occur Within a Two-mile Radius of NREL's National Wind Technology Center

\begin{tabular}{|c|c|}
\hline Common Name & Scientific Name \\
\hline Moss's elfin & Callophrys mossii schryveri \\
\hline Hops feeding azure & Celastrina humulus \\
\hline Mottled dusky wing & Erynnis martialis \\
\hline Ottoe skipper & Hesperia ottoe \\
\hline Cross-line skipper & Polites origenes \\
\hline Regal fritillary & Speyeria idalia \\
\hline \multicolumn{2}{|c|}{ Natural Communities } \\
\hline Xeric tallgrass prairie & $\begin{array}{l}\text { Andropogon gerardii - Schizachyrium scoparium } \\
\text { Western Great Plains herbaceous vegetation }\end{array}$ \\
\hline Xeric tallgrass prairie & $\begin{array}{l}\text { Andropogon gerardii - Sporobolus heterolepis } \\
\text { Western foothills herbaceous vegetation }\end{array}$ \\
\hline Xeric tallgrass prairie & $\begin{array}{l}\text { Andropogon gerardii - Sporobolus heterolepis } \\
\text { Western foothills herbaceous vegetation }\end{array}$ \\
\hline Great Plains mixed grass prairie & $\begin{array}{l}\text { Hesperostipa comate Colorado Front Range } \\
\text { herbaceous vegetation }\end{array}$ \\
\hline Great Plains mixed grass prairie & Hesperostipa neomexicana Herbaceous vegetation \\
\hline Foothills ponderosa pine scrub woodlands & $\begin{array}{l}\text { Pinus ponderosa / Cercocarpus montanus / } \\
\text { Andropogon gerardii Wooded herbaceous } \\
\text { vegetation }\end{array}$ \\
\hline Foothills riparian woodland & Populus angustifolia / Salix irrorata Woodland \\
\hline \multicolumn{2}{|c|}{ Vascular Plants } \\
\hline Dwarf wild indigo & Amorpha nana \\
\hline Forktip three-awn & Aristida basiramea \\
\hline Sedge sp. & Carex oreocharis \\
\hline Rocky Mountain sedge & Carex saximontana \\
\hline Yellow hawthorn & Crataegus chrysocarpa \\
\hline Frostweed & Crocanthemum bicknellii \\
\hline Gay feather & Liatris ligulistylis \\
\hline Wavy-leaf stickleaf & Nuttallia sinuata \\
\hline
\end{tabular}

Walsh reviewed and field verified Special Status Species listed within the CNHP report that were likely to occur onsite. No Special Status Species were observed during all field work conducted during year long surveys conducted at NWTC. 


\section{Vegetation Mapping}

\section{Conservation Management Areas}

As discussed in the 2002 NWTC Sitewide EA (DOE 2002) approximately 60 acres of land within NWTC site boundaries have been designated as Conservation Management Areas not only to prevent development within critical wind corridors but also to protect the site's natural resources. Future building and development are not allowed in ephemeral drainages, hillside seeps, a seasonal pond, mesic mixed grassland (includes tall-grass prairie species), or a prairie dog relocation area (Figure 1).

\section{$\underline{\text { Plant Communities }}$}

The majority of the vegetation on the NWTC site belongs to the mixed-grass prairie association of the grassland formation (Weaver and Clements 1938). Mixed-grass prairie is defined by the presence of grass species typical of the tall-grass or true prairie such as big bluestem (Andropogon gerardii), little bluestem (Schizachyrium scoparium), and prairie dropseed (Sporobolus heterolepis), with species more typical of the short-grass prairie such as blue grama (Chondrosum gracile) and buffalo grass (Buchlöe dactyloides). Intermediate grasses (midgrasses) such as the needle grasses (Hesperostipa and Nassella spp.), wheatgrasses (Pascopyrum, Agropyron, Elytrigia, Elymus, and Thinopyrum spp.), and bluegrasses (Poa spp.) are also important constituents of mixed-grass prairie.

The grasslands on the NWTC site comprise a mosaic of smaller vegetation units that could be delineated and defined based on the presence of two to five key plant species. However, for the purposes of this survey, the grasslands in the NWTC project area fall into the xeric mixed grassland community type identified and classified primarily on available soils and soil moisture, reflected in xeric mixed grassland plant species assemblages.

A number of changes in vegetation patterns were noted since the NWTC site was previously mapped (DOE 1998, Plantae 2000). These observed changes will be discussed by specific plant community, below. The vegetation map is shown in Figure 1. Lists of plant species associated with each plant community are located in Appendix B. Representative photographs of each plant community are found in Appendix C.

\section{Xeric Mixed Grassland}

Xeric mixed grassland is by far the largest and most widespread community type on the NWTC site (Photo 1). These areas do not have access to regular soil moisture (xeric conditions) and are dominated by typical short- and mixed-grass prairie species. This plant community includes a large variety of native grass species as well as a diverse forb component, typical of mixed grasslands. Dominant species noted include yucca (Yucca glauca), crested wheatgrass (Agropyron cristatum), cheatgrass (Anisantha techtorum), smooth brome (Bromopsis inermis), and little bluestem. Species flowering in late spring 2011 include little bluestem, cheatgrass, sand lily (Leucocrinum montanum), wild iris (Iris missouriensis), Lambert locoweed (Oxytropis lambertii), mouse-ear (Cerastium strictum), western wallflower (Erysimum capitatum), and prairie golden pea (Thermopsis rhombifolia). Plant species found in this grassland are listed in Table 1 of Appendix B. 


\section{Mesic Mixed Grassland}

A distinctive single area dominated by big bluestem was mapped as mesic mixed grassland in the southwestern portion of the NWTC site by Plantae (2000). The relative size of the area, as well as the complete dominance of big bluestem, were distinctive enough to designate this community in the current survey (Photo 2). Dominant species noted include big bluestem, smooth brome, Canada thistle (Breea arvensis), and Canada bluegrass (Poa compressa). Species flowering in late spring 2011 include Lambert locoweed. Plant species found in this grassland are listed in Table 2 of Appendix B.

\section{Ponderosa Pine Woodland}

One woodland habitat, defined by a single community, the ponderosa pine woodland, occurs in the northwestern corner of the site along a granite outcrop (Photo 3). This small area supports a very diverse native plant community including common grassland and foothills species, as well as a number of introduced and noxious weeds. Dominant species noted include ponderosa pine, smooth brome, crested wheatgrass, and green needlegrass (Nassella viridula). Species flowering in late spring 2011 include sand lily, western snowberry (Symphoricarpus occidentalis), groundsel (Senecio sp.), and wax current (Ribes cereum). Plant species found in this woodland are listed in Table 3 of Appendix B.

At the beginning of the 2000 growing season, the most dense and widespread diffuse knapweed (Acosta diffusa) population on the NWTC site occurred among the trees in this habitat (Plantae 2000). In the intervening ten years, diffuse knapweed has become ubiquitous across all of the upland plant communities.

\section{Upland Shrubland}

A small upland shrub community is located to the southeast of the ponderosa pine woodland, where the same ridge arises to a lesser degree from the surrounding grassland community (Photo 4). This rocky ridge supports shrub species interspersed with grasses and forbs representative of the surrounding grasslands. Dominant species noted include western snowberry, wax current (Ribes cereum), Canada wild rye (Elymus canadensis), Canada bluegrass, Kentucky bluegrass (Poa pratense), and little bluestem. Species flowering in late spring 2011 include prairie goldenpea. Plant species found in this shrubland are listed in Table 4 of Appendix B.

An isolated group of approximately eight hawthorn (Crataegus erthyropoda) shrubs occurs along the western site boundary, within the NWTC site boundary. These trees are at the top of the slope and occur directly east of an active area of construction disturbance, which is outside the NWTC site boundary and southeast of Coal Creek (Photo 10).

\section{Palustrine Emergent Wetland}

Two wetlands on the site fall into the palustrine emergent category. The first, south of Row 2, is a linear depression on the southern side of the south road. This area appears to have developed as the result of soil excavation intercepting sufficient surface water run-off from the adjacent road to support sedge species (Carex spp.). A second wetland is located on the southern boundary in an area previously disturbed from the neighboring industrial activities. This wetland comprises a center of cattails (Typha angustifolia) surrounded by a stand of coyote willow (Salix exigua).

Two palustrine emergent wetlands were mapped in the mesic mixed grassland in the 2000 growing season. These areas appear to have dried considerably in the intervening ten years. The small wetland pockets of cattails (Typha spp.) that occurred in the southern portions of this area 
are no longer present, apparently replaced, by large stands of Canada thistle. Dead remnants of Baltic rush (Juncus balticus) can be found in the area litter (prior years' herbaceous vegetation). Dominant species noted include smooth brome. Plant species found in this wetland are listed in Table 5 of Appendix B.

\section{Riparian Fringe Wetland}

Areas of riparian fringe wetland occur along the two ephemeral drainages on the NWTC site (Figure 1). Both drainages occur in the northeastern portion of the site, one flowing east and one flowing north. Both show evidence of intermittent surface flow. The northern-most drainage is a tributary of Coal Creek and the second drainage is a tributary to Rock Creek.

Surface flow in the drainage to the northeast appears to be augmented by outflow from the groundwater seep wetland on the western bank (see below). The second and larger drainage (RF1) conducts surface flows through the center of the site off to the eastern fence line. The upper reaches of this drainage are a shallow grassland swale that begins between Rows 3 and 4 . This channel deepens as it flows east across the site. At its eastern reaches, this drainage clearly intercepts subsurface water, although not in sufficient quantities to produce consistent surface flow. Dominant species noted include Canada thistle, Baltic rush, common evening-primrose (Oenothera villosa), smooth brome, and western wheatgrass (Pascopyrum smithii). Plant species found in these riparian fringe communities are listed in Table 6 of Appendix B.

\section{Groundwater Seep Wetland}

Two areas of groundwater seep wetland were located on the NWTC site. The first occurs west of the ponderosa pine woodland, in the northwestern portion of the site along the northern fenceline (Photo 7). The species in and surrounding this draw comprise more upland species than noted in 2000.

A very small area of this wetland community occurs on the banks of the northern drainage (Photo 8). This community is a clearly demarcated area of primarily wetland plants amidst the surrounding grassland. Fifty plant species were identified in this community in 2000, many of which also occur in the riparian fringe wetland to the south. Dominant species noted include smooth brome, mullein species (Verbascum spp.), and common teasel (Dipsacus fullonum). Species flowering in late spring 2011 include common teasel, common dandelion (Taraxicum officinale), and hawthorn. Plant species found in these groundwater seep wetlands are listed in Table 7 of Appendix B.

\section{Seasonal Pond}

A seasonal pond occurs at the northwestern corner of the site, west of the southern terminus of the ponderosa pine woodland (Photo 9). This area appears to depend on an elevated spring and early summer water table for the hydric soil moisture conditions that support this community. Observers have noted that the pond depression often contains standing water in the spring and early summer in some years (Plantae 2000). However, no standing water was observed in this area during the late summer 2010 survey or during the late spring 2011 survey. These drier soil conditions are reflected in a shift of dominant plant species in this community between the 2000 and 2010-2011 survey periods. Dominant species noted include moth mullein (Verbascum blattaria), Canada bluegrass, Kentucky bluegrass, smooth brome, and Canada thistle. Plant species found in this area are listed in Table 8 of Appendix B. 


\section{Disturbed}

These plant associations reflect surface disturbance due to human activities on the site. These areas include roadsides, pad sites, parking lot perimeters, construction sites, and storage areas. Some of these areas have been revegetated and now include a combination of species from surrounding natural plant communities, reclamation species, and adventive (non-native) or ruderal (native or adventive, disturbance colonizer) species. Dominant species noted include smooth brome. Plant species found in this grassland are listed in Table 9 of Appendix B.

\section{Ornamental Trees/Shrubs}

Disturbed areas around the buildings have been landscaped and planted with a combination of native and ornamental trees and shrubs. The trees include multiple species of junipers (Sabina spp.) and pines (Pinus spp.) interspersed with ornamental deciduous trees. Shrubs in these areas are mainly chokecherry (Padus virginiana) and rose (Rosa spp.) bushes.

\section{Noxious Weeds}

A list of noxious weeds found at NWTC is shown in Table 2. Noxious weed populations are illustrated in Figure 2.

Table 2. Noxious Weed Species Identified at the National Wind Technology Center, Colorado August, 2010

\begin{tabular}{|l|c|c|}
\hline \multicolumn{1}{|c|}{ Common Name } & Scientific Binomial & $\begin{array}{c}\text { Estimated Area } \\
\text { (acres) }\end{array}$ \\
\hline Canada thistle & Breea arvensis & * \\
\hline Cheatgrass & Anisantha tectorum & 0.8 \\
\hline Common mullein & Verbascum thapsus & 1.8 \\
\hline Common teasel & Dipsacus fullonum & 0.05 \\
\hline Chicory & Cichorium intybus & 3.5 \\
\hline Dalmatian toadflax & Linaria dalmatica & $10.5^{\star *}$ \\
\hline Diffuse knapweed & Acosta diffusa & 0.1 \\
\hline Leafy spurge & Euphorbia esula & 3.2 \\
\hline Musk thistle & Carduus nutans & 0.3 \\
\hline Sulfur cinquefoil & Potentilla recta & 0.3 \\
\hline Scotch thistle & Onopordum acanthium & 0.03 \\
\hline Whitetop & Cardaria draba & \\
\hline
\end{tabular}

Species in bold font are on the list of top ten priority weeds for Colorado.

*Cheatgrass was pervasive throughout the site and was therefore not mapped.

**Diffuse knapweed is found throughout the site and the estimated area is for higher densities of plants per square meter. 


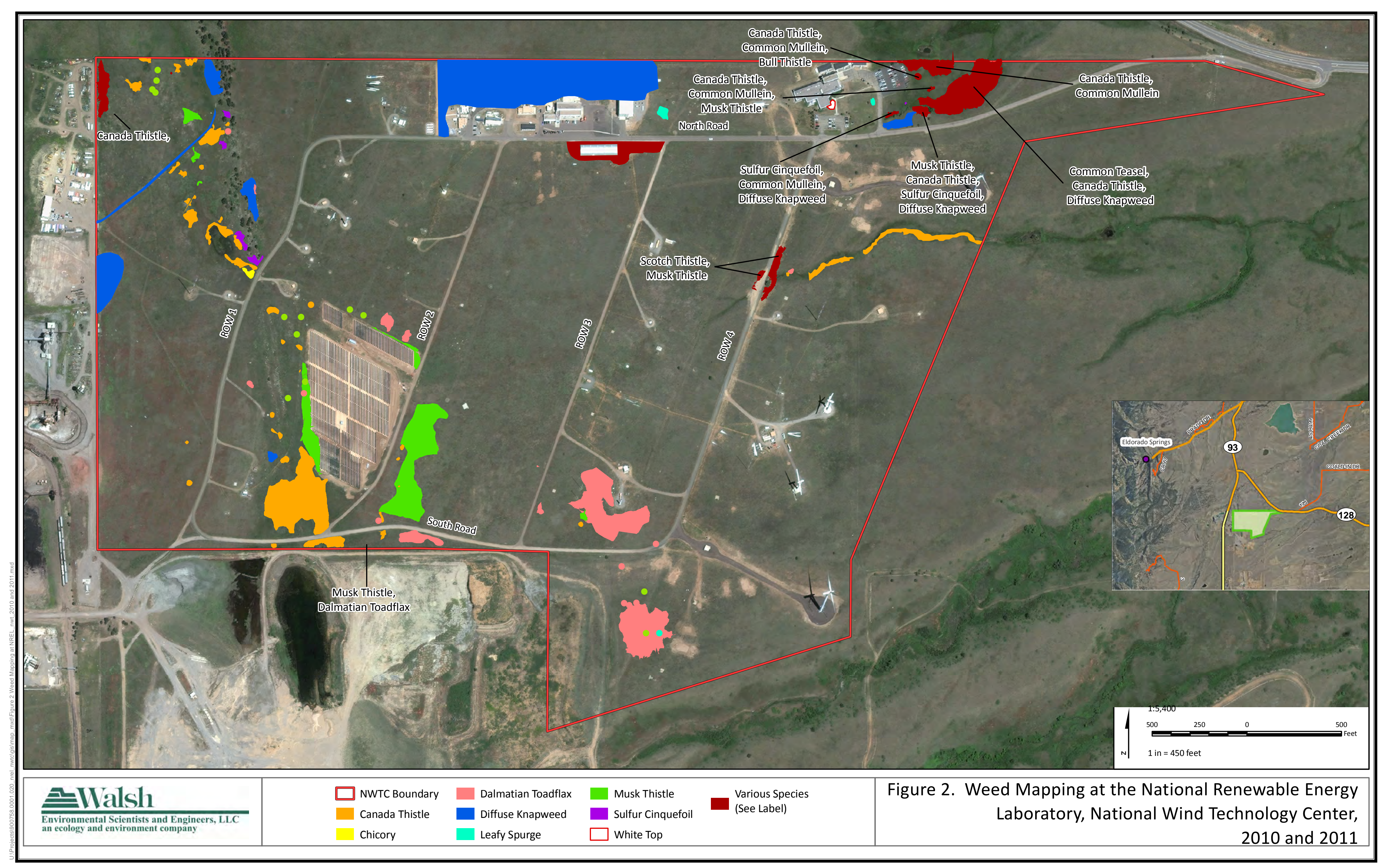




\section{General Wildlife Surveys}

The results of the general wildlife surveys found species typical of the region observed at NWTC. No Special Status wildlife or terrestrial arthropod species were detected during the four seasons of surveys. Mule deer (Odocoileus hemionus) and desert cottontail (Sylvilagus audubonii) were the most commonly observed mammals, seen in a variety of vegetation communities. Woodhouse's toad (Bufo woodhousii) and boreal chorus frog (Pseudacris maculata) were the only detected herpetofauna. Terrestrial arthropods included commonly observed butterfly species such as western white (Pontia occidentalis) and orange sulphur (Colias eurytheme), occurring mostly in xeric mixed grasslands during the summer season. All observations and the associated vegetation community are documented in Table 3. Observation points are documented in Figure 3.

During the fall surveys, three wildlife species were detected. Only signs (scat) of coyote (Canis latrans) and mule deer (tracks, scat, and beds) were found. Woodhouse's toad was detected four times, but only as road-killed individuals. In these cases, the nearest vegetation community is noted for these individuals. In the winter, only mule deer were detected: a group of three in the solar array, and three individuals (detected by a monitor camera) in the northwestern Conservation Management Area. In the spring, a group of 16 mule deer were detected in the conservation easement along the southern boundary of the project area. Desert cottontail rabbit were detected in four locations: three around buildings and one within abandoned black-tailed prairie dog (Cynomys ludovicianus) burrows. In the summer, signs for mule deer and American elk (Cervus canadensis) were observed. NWTC staff have frequently observed elk on the site over the last five to seven years (Tim Johansson via Thomas Ryon, NREL, personal communication), and a boreal chorus frog was observed where the Row Four Road intersects an upper drainage for Rock Creek. A cottontail rabbit was observed on the northern side of the Industrial User Facility. Note: the identification of the cottontails as the desert cottontail was based on habitat, as the three species of cottontails common to the Front Range are very difficult to distinguish in the field (Armstrong et al. 2011).

Table 3. General Wildlife Observations at the National Renewable Energy Laboratory National Wind Technology Center, 2010 - 2011

\begin{tabular}{|l|l|l|}
\hline Common Name & Scientific Name & $\begin{array}{l}\text { Vegetation Community } \\
\text { Code* }\end{array}$ \\
\hline \multicolumn{2}{|c|}{ Mammals } \\
\hline Desert cottontail & Sylvilagus audubonii & BRS \\
\hline American elk (tracks only) & Cervus canadensis & XMG \\
\hline Coyote (scat only) & Canis latrans & XMG \\
\hline $\begin{array}{l}\text { Mule deer (tracks, scats and } \\
\text { beds) }\end{array}$ & Odocoileus hemionus & RFW \\
\hline \multicolumn{2}{|c|}{ Amphibians } \\
\hline Woodhouse's toad (deceased) & Bufo woodhousii & XMG \\
\hline Boreal chorus frog & Pseudacris maculata & RFW, SP \\
\hline \multicolumn{2}{|c|}{ Terrestrial Arthropods } \\
\hline Checkered white & Pontia protodice & RFW \\
\hline
\end{tabular}




\begin{tabular}{|l|l|l|}
\hline Common Name & Scientific Name & $\begin{array}{l}\text { Vegetation Community } \\
\text { Code* }\end{array}$ \\
\hline Western white & Pontia occidentalis & XMG \\
\hline Cabbage white & Pieris rapae & RFW \\
\hline Orange sulphur & Colias eurytheme & XMG \\
\hline Dainty sulphur & Nathalis iole & XMG \\
\hline Gray hairstreak & Strymon melinus & RFW \\
\hline Aphrodite fritillary & Speyeria aphrodite & RFW \\
\hline Common wood nymph & Cercyonis pegala & RFW \\
\hline
\end{tabular}

*Vegetation community code: $\mathrm{XMG}=$ Xeric mixed grassland, $\mathrm{RFW}=$ Riparian fringe wetland, $\mathrm{PEW}=\mathrm{Palustrine}$ emergent wetland, BRS=Building/road/structure, SP=Seasonal pond.

The list of all wildlife species observed from all surveys combined is shown in Appendix D. 


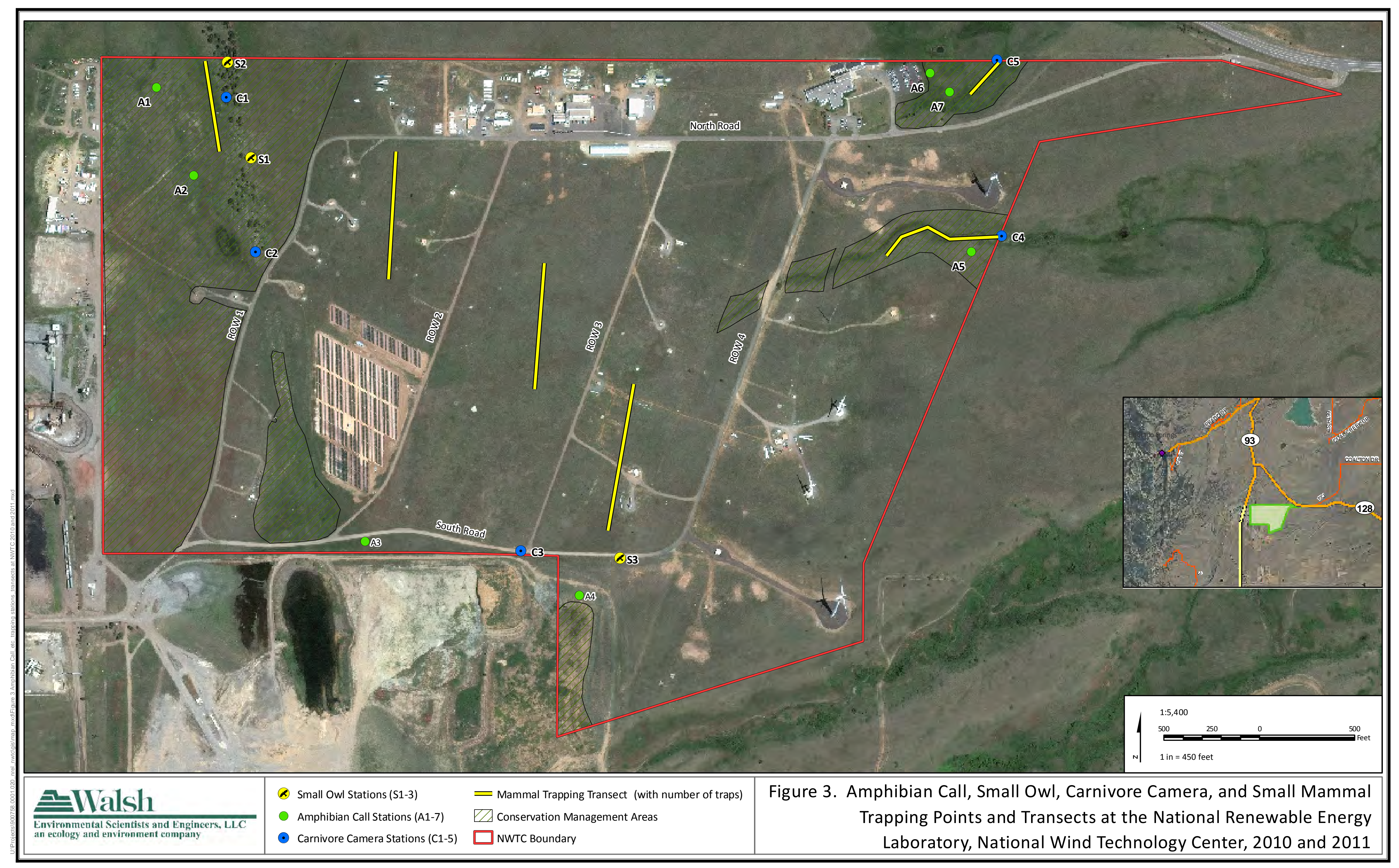




\section{Targeted Wildlife}

\section{Nocturnal Wildlife Surveys}

Nocturnal playback surveys for northern saw-whet owl and northern pygmy-owl failed to detect or elicit any responses from those species. A duetting pair of great horned owls were detected at S2 on February 7.

During the amphibian call surveys boreal chorus frogs were detected on May 3 and 4 at two points: A5 and A7 (Figure 3), however the frogs were outside the boundaries of NWTC. The index value assigned to each observation was 3 , meaning that numerous frogs were heard and the chorus was constant and overlapping. On June 2, boreal chorus frogs were detected at points A3 and A5 outside the boundaries of NWTC with an index value of 2; calls were overlapping but individuals were still distinguishable. A single boreal chorus frog (index value 1) was detected at A2 near a dry ephemeral pond within the boundaries of NWTC.

\section{Carnivore Camera Surveys}

No carnivores were recorded using the motion-detecting monitors. Two photographs were captured of mule deer.

\section{$\underline{\text { Small Mammal Surveys }}$}

Small mammal trapping results are summarized in Table 4. In August 2010, a total of 99 individual small mammals were captured, represented by five species (Table 4). There were 31 recaptures over the four survey nights. Species captured were masked shrew (Sorex cinereus), deer mouse (Peromyscus maniculatus), meadow vole (Microtus pennsylvanicus), prairie vole ( $M$. ochrogaster), and Mexican woodrat (Neotoma mexicana). The masked shrew was captured in the northeast drainage on Transect $C$, and represents a new occurrence record for the site. Deer mice were captured throughout, meadow and prairie voles were captured in the eastern most drainages (Transects B and C), and Mexican woodrats were captured in the western draw on Transect A (Figure 3).

In May 2011, a total of 63 individual small mammals were captured, representing four species (Table 4). There were 26 recaptures. Species captured were deer mouse, western harvest mouse (Reithrodontomys megalotis), meadow vole, and Mexican woodrat. In this trapping event, the deer mice were captured throughout, the western harvest mice were captured in Transects D and E, the lone meadow vole was captured in Transect B, and the lone Mexican woodrat was captured in Transect A (Figure 3).

In August 2010, with 750 trap nights and a total of 130 captures (99 individuals and 31 recaptures), there was a 17 percent capture rate. In May 2011, with 89 captures (63 individual captures and 26 recaptures), there was a 12 percent capture rate.

For the two years combined, the overall capture rate was 15 percent (219 captures out of 1500 trap nights) and there was a species richness of 6: masked shrew, deer mouse, western harvest mouse, meadow vole, prairie vole, and Mexican woodrat. 
Table 4. Small Mammal Captures at the National Wind Technology Center, 2010 and 2011.

\begin{tabular}{|c|c|c|c|c|}
\hline Species & $\begin{array}{c}\text { Xeric } \\
\text { Mixed } \\
\text { Grassland }\end{array}$ & $\begin{array}{c}\text { Xeric Mixed } \\
\text { Grassland/Ponderosa } \\
\text { Pine Woodland }\end{array}$ & $\begin{array}{l}\text { Riparian } \\
\text { Fringe } \\
\text { Wetland } \\
\end{array}$ & Total \\
\hline \multicolumn{5}{|c|}{ Fall 2010} \\
\hline $\begin{array}{l}\text { Masked Shrew } \\
\text { (Sorex cinereus) }\end{array}$ & 0 & 0 & 2 & 2 \\
\hline $\begin{array}{l}\text { Deer Mouse } \\
\text { (Peromyscus maniculatus) }\end{array}$ & $38(13)$ & $13(5)$ & $6(1)$ & $57(19)$ \\
\hline $\begin{array}{l}\text { Mexican Woodrat } \\
\text { (Neotoma mexicana) }\end{array}$ & 0 & 3 & 0 & 3 \\
\hline $\begin{array}{l}\text { Prairie Vole } \\
\text { (Microtus ochrogaster) }\end{array}$ & 2 & 1 & $16(5)$ & $19(5)$ \\
\hline $\begin{array}{l}\text { Meadow Vole } \\
\text { (Microtus pennsylvanicus) }\end{array}$ & 0 & 0 & $11(7)$ & $11(7)$ \\
\hline Vole (Microtus sp.) & 0 & 0 & 7 & 7 \\
\hline \multicolumn{3}{|l|}{ Total } & & 99(31) \\
\hline \multicolumn{5}{|c|}{ Summer 2011} \\
\hline $\begin{array}{l}\text { Western Harvest Mouse } \\
\text { (Reithrodontomys megalotis) }\end{array}$ & 2 & 0 & 0 & 2 \\
\hline $\begin{array}{l}\text { Deer Mouse } \\
\text { (Peromyscus maniculatus) }\end{array}$ & $37(21)$ & $13(4)$ & $6(1)$ & $56(26)$ \\
\hline $\begin{array}{l}\text { Mexican Woodrat } \\
\text { (Neotoma mexicana) }\end{array}$ & 0 & 1 & 0 & 1 \\
\hline $\begin{array}{l}\text { Prairie Vole } \\
\text { (Microtus ochrogaster) }\end{array}$ & 0 & 2 & 0 & 2 \\
\hline $\begin{array}{l}\text { Meadow Vole } \\
\text { (Microtus pennsylvanicus) }\end{array}$ & 0 & 0 & 2 & 2 \\
\hline \multicolumn{4}{|l|}{ Total } & $63(26)$ \\
\hline \multicolumn{5}{|l|}{2010 and 2011 Combined } \\
\hline \multicolumn{3}{|l|}{ Total } & & $162(57)$ \\
\hline
\end{tabular}

All values based on 750 trap-nights. There were 2 closed traps in 2010 and 21 closed traps in 2011. Values in parentheses ( ) indicate recaptures.

The list of all wildlife species observed from all surveys combined is shown in Appendix D. 


\section{Avian Survey Results from Tetra Tech}

Avian surveys conducted by Tetra Tech, Inc. include the following:

- Fixed point

- Breeding bird

- Raptor migration

- Bird and Bat mortality

These surveys were conducted beginning January 2010 to September 2011. The results of these surveys are presented in a separate report.

\section{DISCUSSION}

\section{Background Research}

A number of species were listed in the CNHP query. Other than for arthropods, Special Status Species surveys were not conducted as part of the current study. If one such species was encountered, Walsh would have made a noted, but none of these were found in 2010-2011. This is likely due to a number of reasons, including:

- Some records date as far back as 1984 , and anthropogenic activities since then may have extirpated these populations from NWTC

- Some records are from habitats that occur within two miles but thus habitat is lacking or marginal on NWTC for some species, such as Ute Ladies'-tresses, certain arthropods and Preble's meadow jumping mouse.

- In some cases, the occurrence of favorable moisture or climatic conditions at a future time may cause species to germinate or return to the site.

\section{Vegetation Mapping}

\section{Conservation Management Areas}

Improvements in geospatial analysis and mapping precision since 2000 are likely the reason why the location of the mesic mixed grassland area, as it was mapped in 2010, and the original Conservation Management Area, as it was mapped in 2000, do not overlap with greater precision (Figure 1). In 2010, Walsh ground-truthed the mesic mixed grassland area with sub-foot precision using a Trimble GPS unit. In addition, the appearance of a general drying trend in the area could explain why the mesic mixed grassland has apparently contracted in size since 2000.

\section{$\underline{\text { Plant Communities }}$}

A number of changes in the vegetation patterns were noted since these areas were previously mapped (DOE 1998, Plantae 2000). Overall observed trends in vegetation patterns include a general increase in invasive and noxious weed species diversity and extent across the site and a broad shift in native species composition toward more upland species and fewer species with a wetland indicator status of facultative or wetter. Some possible factors that may be contributing to these apparent trends could include general drying of soils as well as changes in land use, including surface disturbing activities, since 2000. Vegetation mapping is shown in Figure 1. 
The wetlands noted on the site have not been jurisdictionally delineated. Due to a dry winter in 2010, followed by a dry spring in 2011, borders of wetland communities were not able to be confirmed with assurance for this report.

\section{Xeric Mixed Grassland}

The DOE's vegetation mapping effort characterized the majority of the NWTC site as xeric tallgrass prairie in 1998, defined by the dominance of characteristic tall-grass prairie species, most especially big bluestem and little bluestem (DOE 1998). However, this was not found to be the typical condition when the site was mapped in 2000 by Plantae. Instead, at that time, as now, the site supports a diverse matrix of grass species typical of mixed grassland, including distinctive, but very small patches of big bluestem, with the one exception discussed below. It would not be accurate to describe the site as dominated by tall-grass prairie species. Neither does the site experience the climatic conditions or soils that further define tall-grass prairie.

\section{Mesic Mixed Grassland}

A single area of big bluestem was mapped as mesic mixed grassland in the southwest portion of the site by Plantae in 2000. The relative size of this area, as well as the complete dominance of big bluestem, were distinctive enough to designate this community separately. The current mapping effort found this area much reduced in size and of an entirely different character. While big bluestem is still a dominant grass species here, it no longer occurs in a monoculture stand, as described in Plantae (2000). Dominant graminoids observed in 2010-2011 include big bluestem, Canada bluegrass, and cheatgrass. Canada thistle is the dominant forb.

\section{Ponderosa Pine Woodland}

It has been speculated that this forested habitat may represent remnants of a widespread pine forest that once occupied this entire area prior to human timbering and burning (Clark et al. 1980). This now isolated woodland patch serves as bat foraging habitat and as vegetation cover for various mammal and bird species that may not otherwise visit the open grassland mesa top. The understory of this community is composed of a mixture of shrubs, grassland and foothills plant species (Plantae, 2000).

\section{Upland Shrubland}

The isolated group of hawthorns along the western site boundary do not comprise a plant community. The soils and characteristics of the herbaceous layer associated with the hawthorns are contiguous with those of the surrounding xeric mixed grassland. Because this group of trees is upslope and southeast of stretches of Coal Creek, it is possible that groups of hawthorns within the creek's riparian fringe provided a seed source for the hawthorns within the project boundary.

\section{Palustrine Emergent Wetland}

Current field observations found these areas, referred to as cattail seeps in Plantae 2000, are no longer dominated by cattails. In addition, Baltic rush appears to have thrived in these areas at one time, as evidenced by its litter remnants. Although Baltic rush is an obligate wetland species in Region 5 (Reed 1988), it is able to persist in an area for several years after its water source is no longer present. 


\section{Riparian Fringe Wetland}

The two areas of riparian fringe wetland occur along two ephemeral drainages and support wetland plant species not found anywhere else on the NWTC site. This community is a mixture of typical grassland species with those most often found in wetland or riparian areas, as well as introduced species and some noxious weeds.

\section{Groundwater Seep Wetland}

The full sun conditions of this area have allowed common teasel to thrive. It is now the dominant species surrounding the seep and is beginning to spread to the south toward the riparian fringe and ephemeral drainage. Native species diversity has decreased since 2000, likely are a result of the competitive pressure exerted by the expansion of the common teasel.

\section{Seasonal Pond}

The seasonal pond represents an unusual habitat feature in the surrounding xeric mixed grasslands. As observed by Plantae in 2000, the area apparently only holds water as a result of seasonal surface run-off. Saturated soils were not observed in the seasonal pond during site visits due to the general lack of precipitation at those specific times. The general drying trend observed in other vegetation communities throughout NWTC appears to have caused a shift in dominant vegetation in the seasonal pond area as well. This site is no longer dominated by mesic species, such as sedges (Carex spp.), spike-rush (Eleocharis sp.), and rushes (Juncus spp.), observed by Plantae in 2000 and instead supports upland grasses and several ruderal forb species.

\section{Disturbed}

Figure 1 shows a Building/Road/Structure category for anthropogenic features. As is often the case, disturbed areas at the NWTC site appear to show a high correlation with weed populations. Although noxious weed populations occur throughout the NWTC site, larger populations appear to occur near locations where human activities have disturbed the soil surface. Surface disturbance such as building footprints and road construction often leave areas of bare ground where colonizing weeds tend to establish more quickly than amidst established native vegetation. Examples of noxious weed populations establishing and spreading as an apparent result of surface disturbance include populations of Dalmatian toadflax (Lineria dalmatica) associated with access roads between Rows 3 and 4 and south of this area; diffuse knapweed populations associated with the testing and research buildings north of the North Road; and populations of Canada and musk thistle (Carduus nutans) on all sides of the new seven-acre solar array west of Row 2 (Figure 2).

\section{Noxious Weeds}

The NWTC site contains 12 plant species (Table 2) found on the State of Colorado Noxious Weed List. Of these, five are included in the top ten priority weeds for Colorado, as listed in the Colorado Weed Management Act. These species are the most widespread and cause the greatest economic impact to the state and should be considered a priority for the weed management plan developed for the NWTC site.

Many of the noxious weeds found on the site occur in small populations such as leafy spurge (Euphorbia esula), whitetop (Cardaria draba), common teasel, chicory (Cichorium intybus), and scotch thistle (Onopordum acanthium). However, due to the large areas of disturbance on the NWTC site, they are likely to spread if these populations are not actively controlled. 
Diffuse knapweed is scattered throughout the entire site and represents a large threat to native plant diversity. In addition, musk thistle (Carduus nutans), dalmation toadflax, and Canada thistle are found in large populations and appear to be spreading.

Many of the same species of noxious weeds detected in 2010 were also noted when the site was surveyed in 2000 by Plantae, with diffuse knapweed once more covering a large portion of the site. However, it appears many weed populations have increased since 2000, likely in response to surface disturbance associated with three multi-megawatt wind turbines, the former and current prairie dog colony locations, the recent installation of multi-megawatt wind turbines, a new seven acre solar array, and other new facilities.

Because weed populations are now mapped and in a GIS database, baseline cover estimates for the 12 noxious weed species have been established and can be used for comparisons with future weed monitoring efforts.

\section{General Wildlife Surveys}

Species detected during the four seasons of general wildlife surveys were typical of wildlife to be expected in the area. Most were previously documented in the EA (DOE 2002). No Special Status Species of wildlife or terrestrial arthropods were observed. The EA relied on an inventory of wildlife conducted by the DOE of the nearby Rocky Flats Environmental Technology Site (RFETS) which included the NWTC in 1992. Thus a larger area was covered for the EA (DOE 2002) than in the present study, and more wildlife species were included in the EA than in the current study. Thus the differences in species are likely a result of spatial differences between the two studies. The level of effort for surveys in DOE (2002) is not stated and thus comparisons with the present study cannot be made in that regard.

NWTC is documented as resident, summer, and winter range for mule deer and overall, summer, winter, and production range for American elk (NDIS 2011). The EA (DOE 2002) did not document American elk which are increasing on nearby City of Boulder Open Space in the Coal Creek drainage immediately northwest of the site (Steve Jones, personal communication; Scott Severs, Walsh, personal observation). Also NWTC staff has frequently observed elk on-site over the last five to seven years (Tim Johansson via Thomas Ryon, NREL, personal communication).

Two additional species not accounted for in the EA but observed during the current surveys included boreal chorus frog and Woodhouse's toad.

\section{Targeted Wildlife Species}

\section{Nocturnal Wildlife Surveys}

The remnant and small nature of the ponderosa pine forest, and the presence of great horned owls which are a known predator of small owls, likely precluded the presence of northern saw-whet and northern pygmy-owls on the site. Saw-whet owls generally prefer mature and old growth stands of coniferous forests (Rasmussen et. al. 2008) and pygmy-owls generally prefer mixed conifer and deciduous habitats (Holt and Petersen 2000). Both rely on snags for nesting and the NWTC site is mostly devoid of this habitat feature. Preferable hunting and nesting habitats can be found on nearby City of Boulder Open Space properties. Eastern screech-owl (Megascops asio) has been found on adjoining properties in upland shrub habitat (Brenda Beatty - NREL, personal communication). However, this species was not included in surveys as its preferred breeding habitat, plains cottonwood (Populus tremuloides) riparian woodland, does not occur on NWTC. 
Amphibian call surveys only detected the vocalizations of one species, boreal chorus frog at NWTC. General wildlife surveys also and Woodhouse's toad within the property. Dryer than average conditions on NWTC from August 2010 to March 2010 may have influenced detections of calling amphibians.

\section{Carnivore Camera Surveys}

Although no carnivores were photographed by the motion detection monitors, general wildlife surveys did note coyote scat once at NWTC. The carnivore cameras were operating within normal parameters during the survey as evidenced by the two exposures taken of mule deer. This technology is influenced by the motion of vegetation however, which led to nearly all rolls of film being fully exposed. An additional examination of the area around the scent disks did not yield any observations of tracks. The surrounding land uses, habitats, and topography of NWTC does not lend itself to any concentrated areas of carnivore activity or focused movements. NWTC staff has often observed coyotes onsite and on surrounding lands (David Sprowls, NREL, personal communication). Coyotes are known to breed and rear young on the Rocky Flats Wildlife Refuge (previously known as RFETS; Thomas Ryon, NREL, personal communication).

\section{$\underline{\text { Small Mammal Surveys }}$}

The overall capture rate was 15 percent, indicative of a reasonably high general abundance of small mammals. Capture rates of small mammals vary due to a number of factors including location, season, year, precipitation, and in relation to land use and habitat type.

There was a higher number of captures in 2010 than in 2011, due to the higher number of voles in 2010. There were 37 individuals captured in 2010 and only 4 individuals captured in 2011 of both meadow and prairie voles combined. This was likely due to a very dry 2011 winter and spring east of the mountains, as both species are associated with riparian areas or general drainage basins (Armstrong et al. 1994). Furthermore, small mammal densities are known to fluctuate widely over time (Smith et al. 2009). During both trapping events, five species were captured. The masked shrew was captured in 2010 but not in 2011, whereas the western harvest mouse was captured in 2011 but not in 2010. Otherwise, species representation was the same. Although not captured, burrow holes and runways of the thirteen-lined ground squirrel (Spermophilus tridecemlineatus) were observed in the xeric mixed grassland. This species was reported present in 2002 (DOE 2002) and likely is still present.

The species richness of six captured species of small mammals in 2010-2011 at NWTC is high relative to Walsh's extensive trapping experience all along the Front Range. This is likely due, in part, to the combination of different habitat types found on the site. It also indicates that the site does have biodiversity value, especially for small mammals. Small mammals, in turn, support biodiversity by serving as prey to many species of predators including snakes, raptors, and coyotes.

The previous work (DOE 2002) found four species, deer mouse, prairie vole, thirteen-lined ground squirrel, and Mexican woodrat. Other than the thirteen-lined ground squirrel, all those species were captured during the present surveys as well as the masked shrew and western harvest mouse. It is not known if the species richness has increased, or more likely, the trapping effort was greater and/or that conditions favoring the moisture-dependent masked shrew and meadow vole were present in 2010.

Of the three habitats sampled, xeric mixed grassland and xeric mixed grassland/Ponderosa pine woodland had three small mammal species each, whereas the riparian fringe wetland had four 
species. Riparian corridors are known to be favored habitats for many faunal species, small mammals included.

The possibility of the occasional occurrence of a Preble's meadow jumping mouse (Zapus hudsonius preblei) on one of the two riparian fringe wetlands, tributaries of Coal Creek (Transect C) and Rock Creek (Transect B), or the draw in the Conservation Management Area on the west side of the site (Transect A) should not be ruled out, especially during wet years (Figure 3). Both Coal Creek and Rock Creek are known to be occupied by this mouse, listed as threatened under the Endangered Species Act. Preble's mice occur on the adjacent Rocky Flats Wildlife Refuge (previously known as RFETS), where their dispersal and daily movements have been studied (Ryon 1999). There also was an unexpected 1997 off-site capture of a Preble's mouse in close vicinity to the site. That occurrence was in a roadside gully on the western side of SH93 (ETS 1997, as cited in DOE 2002) and tributary to Coal Creek. Preble's mice have the ability to move into the headwater tributaries on the NWTC, however the habitat is marginal and the value of such movements would be difficult to determine. This headwater tributary may be accessed by transient individuals seeking suitable habitat or could be used as hibernation sites, perhaps in years when other more suitable habitat is occupied. Transient individuals could move through the site to access other suitable habitat areas in Coal Creek or Rock Creek on the Rocky Flats Wildlife Refuge. However, such movements are likely very rare. It is important to note that the vegetation types that a Preble's mouse would possibly use on the NWTC are already Conservation Management Areas and these areas will be protected from impacts for a variety of environmentally related reasons, including preservation of wetlands, water quality and site diversity.

\section{RECOMMENDATIONS}

Based on the observations discussed above, there are several measures and recommendations that could minimize impacts to native vegetation communities and wildlife in relation to the presence of the wind testing development activities on site. These include:

- Develop the smallest possible footprint for turbines, access roads, and other infrastructure. For example, if a new road is needed, determine what can be the narrowest width and shortest extent, or use a two-track rather than a proper road.

- Minimize disturbance to native plant communities to benefit native grassland species of amphibians, reptiles, birds, and mammals.

- To protect native plant community biodiversity, eradicate small weed populations, monitor for new weed infestations, and actively manage weeds on-site through NREL's aggressive weed control program (DOE 2002, Jefferson County Nature Association 2009).

- As suggested by Avian Power Line Interaction Committee (APLIC 2006), fit new power and communication towers with perch guards; design powerline conductor spacing to minimize the potential for raptor electrocutions (52 inches apart for raptors); design transmission lines to have the top two wires (lightning/ground wires) made visible.

- Equip permanent meteorological towers with Bird Flight Diverters to minimize the potential for avian collisions with guy wires, or utilize meteorological towers that are constructed without the use of guy wires.

- Adhere to Executive Order (EO) 13186 - Responsibilities of Federal Agencies to Protect Migratory Birds (January 17, 2001); the memorandum of understanding (MOU) between 
DOE and USFWS regarding EO 13186 (November 13, 2006); and the MOU between the Trustee Council for Natural Resources at Rocky Flats, and DOE's Office of Energy Efficiency and Renewable Energy (EERE) (June 30, 2009).

- Consider preparation of an Avian and Bat Protection Plan (ABPP) as part of the ongoing site activities.

\section{REFERENCES}

Armstrong , D.M., J.P. Fitzgerald, and C.A. Meaney. 2011. Mammals of Colorado. University Press of Colorado, Niwot. 467 pp.

Avian Power Line Interaction Committee (APLIC). 2006. Suggested practices for avian protection on power lines: State of the art 2006. Edison Electric Institute, APLIC, and the California Energy Commission. Washington, D.C., and Sacramento, California.

Clark, S.V., P.J. Webber, V. Komarkova, and W.A. Weber. 1980. Map of Mixed Prairie Grassland and Vegetation Rocky Flats, Colorado. Institute of Arctic an Alpine Research. Occasional Paper No. 35. University of Colorado.

Colorado Department of Agriculture (CDOA). 2010. Colorado Noxious Weed List. http://www.colorado.gov/cs/Satellite/Agriculture-Main/CDAG/1174084048733. Accessed online 6/2010.

Colorado Division of Wildlife (CDOW). 2010. Species of Concern. http://wildlife.state.co.us/WildlifeSpecies/SpeciesOfConcern/ThreatenedEndangeredList/ ListOfThreatenedAndEndangeredSpecies.htm

Droege, S. Amphibian Calling Surveys. USGS Patuxent Wildlife Research Center, Laurel, MD. http://www.pwrc.usgs.gov/monmanual/techniques/amphibcallingsurveys.htm. Accessed online $3 / 2010$.

Ensight Technical Services (ETS). 1997. Presence or absence survey for Preble’s meadow jumping mouse at Western Aggregate, Jefferson County, Colorado. Technical report prepared for Colorado Department of Transportation Project BR 093-1(16) SH 93 North of SH 72, Western Aggregate Bridge.

Francis, C.M. and Bradstreet, M.S.W. 1997. Monitoring Boreal Forest Owls in Ontario using tape playback surveys with volunteers. In: Duncan, James R.; Johnson, David H.; Nicholls, Thomas H., eds. Biology and conservation of owls of the Northern Hemisphere: 2nd International symposium. Gen. Tech. Rep. NC-190. St. Paul, MN: U.S. Dept. of Agriculture, Forest Service, North Central Forest Experiment Station. 175-184.

Holt, D.W. and J.L. Petersen. 2000. Northern Pygmy-Owl (Glaucidium gnoma), The Birds of North America Online (A. Poole, Ed.). Ithaca: Cornell Lab of Ornithology; Retrieved from the Birds of North America Online: http://bna.birds.cornell.edu/bna/species/494

Jefferson County Nature Association. 2009. Rocky Flats Restoration Enhancement. 2009 Annual Report prepared for the Trustee Council for Natural Resources at Rocky Flats. Submitted to Colorado Department of Public Health and Environment under PO FEA HAZ 104960. 
Monahan, M.W. 1996. Raptor presence in and around the National Wind Technology Center: An assessment of risks and management alternatives. National Renewable Energy Laboratory, Golden, Colorado.

Natural Diversity Information System (NDIS). 2011. http://ndis.nrel.colostate.edu/wildlifespx.asp?SpCode $=051044$

Plantae Consulting Services. 2000. Vegetation Survey Report. National Renewable Energy Laboratory National Wind Technology Center. September 30, 2000.

Rasmussen, J.L., S.G. Sealy, and R.J. Cannings. 2008. Northern Saw-whet Owl (Aegolius acadicus), The Birds of North America Online (A. Poole, Ed.). Ithaca: Cornell Lab of Ornithology; Retrieved from the Birds of North America Online: http://bna.birds.cornell.edu/bna/species/042

Reed, Jr., P. B. 1988. National list of plant species that occur in wetlands: Central plains, (Region 5). U.S. Department of Interior, Fish and Wildlife Service Biol. Rept. 88 (26.5).

Ryon, T. R. 1999. Travel distance and movement patterns of the Preble's meadow jumping mouse (Zapus hudsonius preblei) at the Rocky Flats Environmental Technology Site. Journal of Colorado-Wyoming Academy of Science 31:12.

Schmidt, E., A.J. Piaggio, C.E. Bock, and D.M. Armstrong. 2003. National Wind Technology Center Site Environmental Assessment: Bird and Bat Use and Fatalities-Final Report. NREL/SR-500-32981.

Sikes, R.S., W.L. Gannon, and the Animal Care and Use Committee of the American Society of Mammalogists. 2011. Guidelines of the American Society of Mammalogists for the use of wild mammals in research. Journal of Mammalogy, 92(1):235-253. http://mammalsociety.org/committees/index.asp

Smith, M.H. et al. 2009. Density estimations of small mammal populations. Pp 25-53 in (F.B. Golley, K. Petrusewicz, and L. Ryszkowski, eds.) Small mammals: their productivity and population dynamics. Cambridge University Press, Cambridge.

U.S. Department Of Energy (DOE). May 2002. Site-Wide Environmental Assessment (EA) of National Renewable Energy Laboratory’s (NREL) National Wind Technology Center (NWTC). Golden, Colorado

U.S. Department of Energy (DOE). August 1998. Rocky Flats Environmental Technology Site Vegetation Map. Rocky Mountain Remediation Services (RMRS). Map ID: 02-0208. Golden, Colorado.

U.S. Fish and Wildlife Service (USFWS). July 2010. Endangered, Threatened, and Candidate Species and Designated Critical Habitat for Colorado Counties. http://www.fws.gov/mountain\%2Dprairie/endspp/countylists/colorado.pdf

Weaver, J. E. and F. E. Clements. 1938. Plant Ecology. McGraw-Hill. Book Company, Inc., New York. 524 pp.

Weber, W.A. and R.C. Wittmann. 2001. Colorado Flora: Eastern Slope. University of Colorado Press. Third Edition. Boulder Colorado. 


\section{APPENDIX A}

Colorado Natural Heritage Program Data Query Response 


\section{Colorado Natural Heritage Program Terminology Cheat Sheet For Conservation Data Provided in Environmental Review Reports \& Program Related Web-links}

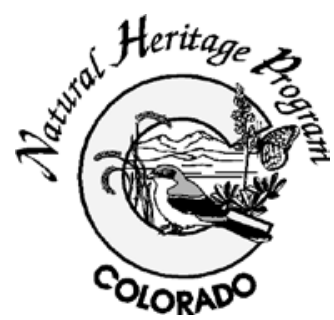

\section{Selected Web Links:}

Colorado Natural Heritage Program: CNHP is a leading source in the state for the biodiversity information that is essential for effective planning and successful conservation efforts. CNHP is a nonprofit organization, and is a sponsored program of the College of Natural Resources, Department of Fishery and Wildlife Biology at Colorado State University. We are also a member of the Natural Heritage Network, an international network of partners that use the same scientific methodology to enable planners, scientists and policy-makers to monitor the status of species and natural communities from state, national, and global perspectives.

http://www.cnhp.colostate.edul - CNHP's home page. See related links on our home page to products and services available such as environmental review, data requests, biological assessments, publications, and more. Staff contacts are available here as well.

\section{CSU:}

http://welcome.colostate.edul - We are an independent non-profit that is a sponsored program at Colorado State University, but other state natural heritage programs are often a part of state government.

http://warnercnr.colostate.edul - The Warner College of Natural Resources at CSU, where CNHP is housed.

NatureServe: NatureServe works in partnership with 85 independent Natural Heritage programs and Conservation Data Centers that gather scientific information on rare species and ecosystems in the United States, Latin America, and Canada (the Natural Heritage Network).

http://www.natureserve.orgl - also see conservation information and data available on http://www.natureserve.org/explorerl - for detailed information on species and natural communities.

http://www.landscope.orgl - the conservation guide to America's natural places providing an online resource for the land-protection community and the public. 


\section{Environmental Review Report Attribute Definitions}

\section{Attribute_Label: Highest EO Rank}

Attribute_Label_Definition:

The EO rank assigned to each occurrence represents a comparative evaluation summarizing several factors. These include quality (how closely the occurrence matches the EO specifications including maturity, size, numbers, etc.), condition (how much has the site and the element occurrence itself has been damaged or altered from its optimal condition and character), viability (the long-term prospects for continued existence of the occurrence), and defensibility (the extent to which the occurrence can be protected from anthropogenic factors that might otherwise degrade or destroy it). The rank is assigned on the basis of recent fieldwork by a knowledgeable individual. The best occurrence of an element in a state may bot necessarily be assigned an " $A$ " rank. It may be assigned a lower rank if somewhere else in the element's global range, there are occurrences that merit a higher rank. Blank values indicate that the rank is under scientific review.

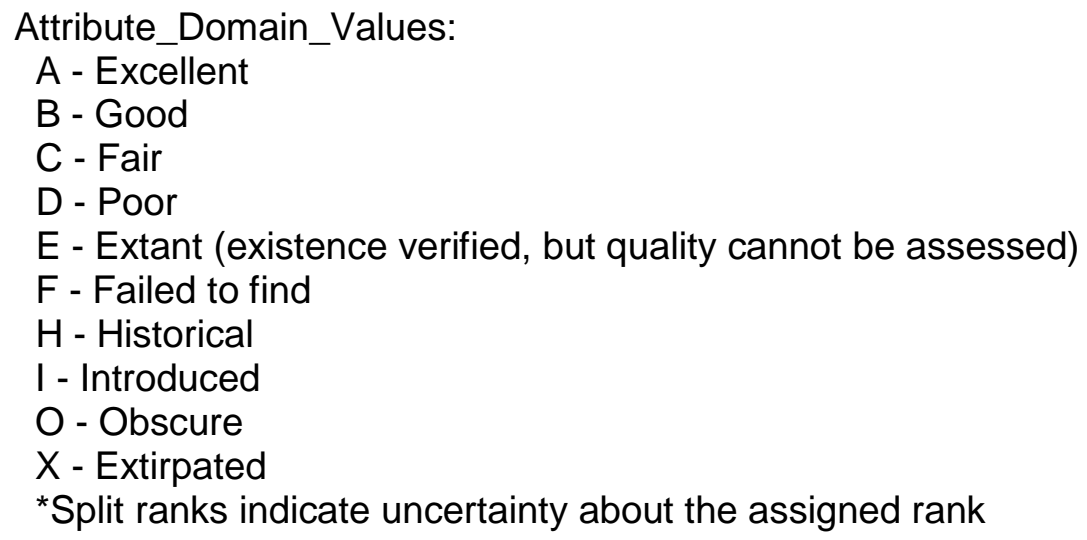

Attribute_Label: Global Rank

Attribute_Label_Definition:

The global element rank that best characterizes the relative rarity or endangerment of the element worldwide. Global ranks are derived primarily by staff at the Central Heritage Conservation Science Department, unless CNHP has lead responsibility for that element.

Attribute_Domain_Values:

G1 - Globally critically imperiled; typically 5 or fewer occurrences

G2 - Globally imperiled; typically 6 to 20 occurrences

G3 - Globally vulnerable; typically 21 to 100 occurrences

G4 - Globally apparently secure; usually > 100 occurrences

G5 - Globally demonstrably secure although it may be rare in parts of its range

G\#G\# - A range between two of the numeric ranks; indicates uncertainty about the rarity of the element

G? - Unranked; element is not yet ranked globally

GU - Unrankable; not enough information is known

$\mathrm{GH}$ - Historically known with hopes of rediscovery 
GX - Extinct; unlikely to be rediscovered

T\# - Rank applies to a subspecies or variety

Q - Taxonomic status is questionable

C - Element is extant only in captivation or cultivation

*Other factors, in addition to the number of occurrences, may be considered when assigning a global rank

Attribute_Label: State Rank

Attribute_Label_Definition:

The state element rank that best characterizes the relative rarity or endangerment of the element statewide. State ranks are derived by CNHP staff.

Attribute_Domain_Values:

S1 - State critically imperiled; typically 5 or fewer occurrences

S2 - State imperiled; typically 6 to 20 occurrences

S3 - State vulnerable; typically 21 to 100 occurrences

S4 - State apparently secure; usually > 100 occurrences

S5 - State demonstrably secure

S\#S\# - A range between two of the numeric ranks; indicates uncertainty about the rarity of the element

S? - Unranked; element is not yet ranked in the state

SU - Unrankable; not enough information is known

$\mathrm{SH}$ - Historically known with hopes of rediscovery

SX - Extinct; unlikely to be rediscovered

SE - An exotic established in the state; native to a nearby region

SA - Accidental; includes species (usually birds or butterflies) recorded once or twice or only at very great intervals, hundreds or thousands of miles outside their usual range

B - Rank refers to the breeding population of the element

$\mathrm{N}$ - Rank refers to the nonbreeding population of the element

C - Element is extant only in captivation or cultivation

*Other factors, in addition to the number of occurrences, may be considered when assigning a state rank

Attribute_Label: Fed Listed

Attribute_Label_Definition:

The federal legal status of the species as assigned by the U.S. Fish and Wildlife Service.

Attribute_Domain_Values:

C - ESA candidate

LE - Listed endangered

LE-PDL - Listed endangered, proposed delisting

LT - Listed threatened

PT - Proposed threatened

(PS) - Partial status; infraspecific taxon or population has federal status but the entire species does not - status in only a portion of the species' range

(LE-XN) - Listed as endangered; a nonessential experimental population exists in Colorado 
*Blank values indicate no federal legal status per USFWS

Attribute_Label: Fed Sens

Attribute_Label_Definition:

Denotes species considered sensitive by the U.S. Forest Service and/or the

Bureau of Land Management (does NOT include ESA status).

Attribute_Domain_Values:

BLM - Legal status assigned by the Bureau of Land Management

FS - Legal status assigned by the U.S. Forest Service

FS/BLM - Legal status assigned by both the U.S. Forest Service and the Bureau of Land Management

*Blank values indicate no federal legal status per BLM or USFS

Attribute_Label: State Listed

Attribute_Label_Definition:

The state legal status of vertebrate or invertebrate species as assigned by the Colorado Division of Wildlife.

Attribute_Domain_Values:

$\mathrm{E}$ - State endangered; elements of native wildlife whose prospects for survival or recruitment within this state are in jeopardy

$\mathrm{T}$ - State threatened; elements that are not in immediate jeopardy of extinction, but are vulnerable due to small numbers, restricted throughout its range, or experiencing low recruitment or survival

SC- Special concern

*Blank values indicate no state legal status per CDOW

Attribute Label: Precision

Attribute_Label_Definition:

Precision refers to the accuracy of the location of the element occurrence. CNHP compiles data from a variety of sources including published and unpublished literature, herbaria and museum labels, personal communication, and documentation of actual field surveys conducted by CNHP staff, Forest Service personnel, or other knowledgeable individuals. The level of spatial uncertainty, then, varies from occurrence to occurrence.

Attribute_Domain_Values:

S - Seconds precision; essentially an "X" marks the spot"; mapable to within approximately 3 arc seconds of latitude and longitude

$M$ - Minutes precision; mapable within approximately 2 square miles

G - General precision; mapable within approximately two USGS 7.5 minute quadrangles 


\title{
Data Dictionary for Network of Conservation Areas Transcription Reports from the Colorado Natural Heritage Program
}

\author{
This Data Dictionary defines terms used in Network of Conservation Areas (NCA) Reports \\ exported by the Colorado Natural Heritage Program (CNHP) from our Biodiversity Tracking and \\ Conservation System (BIOTICS) database.
}

Introduction to Network of Conservation Areas

A Network of Conservation Areas (NCA) will fit one of the following definitions:

\begin{abstract}
A. A landscape area that encompasses Potential Conservation Areas (PCAs) that share similar species or natural communities and ecological processes. NCAs include unoccupied or unsurveyed areas that are within the same ecological system that the species or natural communities require. NCAs contain PCAs with an obvious repeating pattern (that is, the same species or natural communities are in each associated PCA).
\end{abstract}

B. A mostly intact, lightly fragmented landscape that supports wide-ranging species and large scale disturbances. NCAs include unoccupied or unsurveyed areas that demonstrate the connectivity of the landscape. NCAs contain PCAs that may occur at a variety of ecological scales.

\section{Potential Conservation Area \\ In order to successfully protect populations or occurrences, it is necessary to delineate conservation areas. These potential conservation areas focus on capturing the ecological processes that are necessary to support the continued existence of a particular element of natural heritage significance. Potential conservation areas may include a single occurrence of a rare element or a suite of rare elements or significant features.}

The goal of the process is to identify a land area that can provide the habitat and ecological processes upon which a particular element or suite of elements depends for their continued existence. The best available knowledge of each species' life history is used in conjunction with information about topographic, geomorphic, and hydrologic features, vegetative cover, as well as current and potential land uses. The proposed boundary does not automatically exclude all activity. It is hypothesized that some activities will cause degradation to the element or the process on which they depend, while others will not. Consideration of specific activities or land use changes proposed within or adjacent to the preliminary conservation planning boundary should be carefully considered and evaluated for their consequences to the element on which the conservation unit is based.

\section{Element Occurrence}

An Element Occurrence (EO) is defined as a specific example of an Element at a geographic location characterized by a habitat capable of sustaining or contributing to the survival of the species, or by a landscape that supports the ecological integrity of the community.

\section{Element}

A biodiversity unit of conservation attention and action for which a Heritage Conservation Status Rank is assigned.

Elements may be recognized at any taxonomic level (although typically are only recognized at the species level and below for organisms, and the Ecological System, Alliance, and Association levels for communities).

Elements may also be recognized for biodiversity units for which there is no systematic hierarchy (e.g., animal assemblages, community Complexes).

Elements may be native or exotic at a particular location and collectively represent the full array of biological and ecological diversity for the geographic area covered. Elements may serve as the 
targets of Heritage inventory. Typically, these targets include native, regularly occurring vulnerable species (including infraspecific taxa and populations) and exemplary ecological communities.

\section{REPORT HEADER}

\section{Name}

The official CNHP site name, usually corresponding to a local place name or nearby geographic feature.

\section{Site Code}

Unique identifier previously used in the BCD for a site record.

\section{IDENTIFIERS}

\section{Site ID}

Unique identifier for a site.

\section{Site Class}

Value that indicates whether a site is a Potential Conservation Area (PCA) or Network of Conservation Areas (NCA).

Domain values for Site Class are:

$$
\begin{aligned}
& \text { PCA } \\
& \text { NCA }
\end{aligned}
$$

\section{Site Alias}

Other names commonly associated with the NCA. These can include informal names, old site names, names used by other offices or cooperating organizations, or the original survey site name.

\section{Site Relations}

Comments that explain the relationship between this site and any nested, overlapping, or adjacent sites.

\section{LOCATORS}

\section{Nation}

State

\section{Latitude}

Degrees, Minutes, Seconds. Datum is NAD 27. Calculated in GIS.

\section{Longitude}

Degrees, Minutes, Seconds. Datum is NAD 27. Calculated in GIS. 


\section{Quad Code}

Calculated in GIS.

\section{Quad Name}

Calculated in GIS.

\section{County}

Calculated in GIS.

Watershed Code

U.S.G.S. 8-digit hydrologic unit code. Calculated in GIS.

\section{Watershed Name}

U.S.G.S. watershed name. Calculated in GIS.

Site Directions [provided with Level 1 data only]

Specific directions to the site provided by the designer or version author.

\section{SITE DESCRIPTION}

\section{Minimum Elevation}

Minimum elevation provided by the designer or version author.

\section{Maximum Elevation}

Maximum elevation provided by the designer or version author.

\section{Site Description}

General visual description (or word picture) of the principal physical and natural features on the site.

\section{Key Environmental Factors}

Description of the driving factors or key environmental variables that are known to exert a major influence on the biota at the site (e.g., seasonal flooding, wind, soil type).

\section{Climate Description}

General comments concerning climate and weather patterns, wind patterns, seasonal and annual variations, as well as temperature and precipitation patterns characteristic of the site.

\section{Land Use History}

Comments concerning past land uses on this site (such as mining, logging, shifting cultivation, etc.).

\section{Cultural Features}

Comments concerning any historic, cultural, or archaeological features found on the site (e.g., pictographs, petroglyphs, burial mounds, prehistoric artifacts). 


\section{SITE DESIGN}

\section{Site Map}

Indicates whether a site boundary was field verified or drawn from desktop references.

Domain values for Site Map are:

$\mathrm{P}$ - partial; drawn from desktop references

$\mathrm{Y}$ - field verified by CNHP personnel

\section{Mapped Date}

Date site boundary was last redrawn.

\section{Designer}

CNHP biologist responsible for drawing the site boundary.

\section{Boundary Justification}

Explanation of the biological rationale used to determine the ecological boundaries for the site.

\section{Primary Area}

Area of the NCA polygon. Calculated in GIS.

\section{OTHER/PROTECTION/MANAGEMENT RANKS}

\section{Other Values Rank}

Value that indicates the rating that best describes the significance of the site in terms of its aesthetic, recreational, open space, and other ecological values; this includes its role in maintaining ecosystem health (e.g., by providing game and wildlife habitat, aquifer recharge functions, erosion control).

Domain values for Other Values are:

V1 - Outstanding values

V2 - High values

V3 - Moderate values

V4 - No known values

V5 - Negative or counter values

V? - Unknown

(null) - Not assessed

\section{Other Values Comments}

Comments that justify the rating assigned for the site in the Other Values field.

\section{Protection Urgency Rank}

Value that indicates the rating that best describes the urgency to protect the Site. The urgency for protection action (not to be confused with the urgency for management action) will generally increase with impending threats to the site until legal, political, or other administrative measures are taken. 
Domain values for Protection Urgency are:

P1 - Immediately threatened/outstanding opportunity

P2 - Threat/opportunity within 5 years

P3 - Definable threat/opportunity, but not within 5 years

P4 - No threat or special opportunity

P5 - No action to be taken on this site

P? - Unknown

\section{Protection Urgency Comments}

Comments that justify the rating assigned for the site in the Protection Urgency field.

\section{Management Urgency Rank}

Value that indicates the rating that best describes the urgency to manage one or more Elements at the site. The urgency for management action (not to be confused with the urgency for legal protection action) requires stewardship intervention in order to maintain EOs at the site.

Domain values for Management Urgency are:

M1 - Essential within 1 year to prevent loss

M2 - Essential within 5 years to prevent loss

M3 - Needed within 5 years to maintain quality

M4 - Not needed now; no current threats; may need in future

M5 - Not needed; no threats anticipated

M? - Unknown

\section{Management Urgency Comments}

Comments that justify the rating assigned for the site in the Management Urgency field.

\section{LAND MANAGEMENT ISSUES}

\section{Land Use Comments}

Description of the current and past land use, improvements, and structures on the site.

\section{Natural Hazard Comments}

Description of the potential natural hazards (e.g., cliffs, caves, waterfalls) on the site, along with any precautions that should be taken by stewards.

\section{Exotics Comments}

Description of potentially damaging exotic (i.e., alien) flora and fauna (e.g., kudzu, honeysuckle, purple loosestrife, periwinkle, English ivy, feral goats, pigs) on the site.

\section{Offsite}

Description of off-site land uses (e.g., farming, logging, grazing, dumping, watershed diversion), and how these uses might affect the site and management of the site. 


\title{
Information Needs
}

Summary of the information that is still needed in order to effectively manage the site.

\section{Management Needs}

Summary of the expected management needs for the site.

\section{Managed Area Relations}

Explanation of the site/Managed Area relationship, if a Managed Area has been (or will be) established to protect the site.

\section{Protection Comments}

Summary of the general level of protection currently afforded the site that indicates the current protection status of component Tracts.

\section{ASSOCIATED POTENTIAL CONSERVATION AREAS}

(PCAs known from the area of a given NCA.)

\begin{abstract}
Potential Conservation Area
In order to successfully protect populations or occurrences, it is necessary to delineate conservation areas. These potential conservation areas focus on capturing the ecological processes that are necessary to support the continued existence of a particular element of natural heritage significance. Potential conservation areas may include a single occurrence of a rare element or a suite of rare elements or significant features.
\end{abstract}

\begin{abstract}
The goal of the process is to identify a land area that can provide the habitat and ecological processes upon which a particular element or suite of elements depends for their continued existence. The best available knowledge of each species' life history is used in conjunction with information about topographic, geomorphic, and hydrologic features, vegetative cover, as well as current and potential land uses. The proposed boundary does not automatically exclude all activity. It is hypothesized that some activities will cause degradation to the element or the process on which they depend, while others will not. Consideration of specific activities or land use changes proposed within or adjacent to the preliminary conservation planning boundary should be carefully considered and evaluated for their consequences to the element on which the conservation unit is based.
\end{abstract}

\section{PCA Site ID}

Unique identifier for the PCA associated with this NCA.

\section{PCA Site Name}

The official CNHP site name for the PCA associated with this NCA.

\section{PCA Biological Diversity Significance}

The Biodiversity Significance Rank of the PCA associated with this NCA. This value indicates the rating that best describes the significance of the PCA in terms of its biological diversity.

Domain values for Biodiversity Significance are:

B1: Outstanding Biodiversity Significance

B2: Very High Biodiversity Significance

B3: High Biodiversity Significance 
B4: Moderate Biodiversity Significance

B5: General interest/open space

\section{REFERENCES}

\section{Reference ID}

The identifier for a reference available for this NCA.

\section{Full Citation}

Formal citation for a reference associated with the NCA.

\section{ADDITIONAL TOPICS}

\section{Additional Topics}

Specific comments on any significant additional nonstandard topics that have not been formally addressed by one of the standard fields in this record.

\section{VERSION}

Version Date

Date report information for the NCA was last reviewed or updated.

Version Author

Author of the current version of the transcription in this report. 


\title{
Data Dictionary for Potential Conservation Area Transcription Reports from the Colorado Natural Heritage Program
}

\author{
This Data Dictionary defines terms used in Potential Conservation Area (PCA) Reports exported \\ by the Colorado Natural Heritage Program (CNHP) from our Biodiversity Tracking and \\ Conservation System (BIOTICS) database.
}

\begin{abstract}
Introduction to Potential Conservation Areas
In order to successfully protect populations or occurrences, it is necessary to delineate conservation areas. These potential conservation areas focus on capturing the ecological processes that are necessary to support the continued existence of a particular element of natural heritage significance. Potential conservation areas may include a single occurrence of a rare element or a suite of rare elements or significant features.

The goal of the process is to identify a land area that can provide the habitat and ecological processes upon which a particular element or suite of elements depends for their continued existence. The best available knowledge of each species' life history is used in conjunction with information about topographic, geomorphic, and hydrologic features, vegetative cover, as well as current and potential land uses. The proposed boundary does not automatically exclude all activity. It is hypothesized that some activities will cause degradation to the element or the process on which they depend, while others will not. Consideration of specific activities or land use changes proposed within or adjacent to the preliminary conservation planning boundary should be carefully considered and evaluated for their consequences to the element on which the conservation unit is based.
\end{abstract}

\section{Element Occurrence}

An Element Occurrence (EO) is defined as a specific example of an Element at a geographic location characterized by a habitat capable of sustaining or contributing to the survival of the species, or by a landscape that supports the ecological integrity of the community.

\section{Element}

A biodiversity unit of conservation attention and action for which a Heritage Conservation Status Rank is assigned.

Elements may be recognized at any taxonomic level (although typically are only recognized at the species level and below for organisms, and the Ecological System, Alliance, and Association levels for communities).

\section{Elements may also be recognized for biodiversity units for which there is no systematic hierarchy} (e.g., animal assemblages, community Complexes).

Elements may be native or exotic at a particular location and collectively represent the full array of biological and ecological diversity for the geographic area covered. Elements may serve as the targets of Heritage inventory. Typically, these targets include native, regularly occurring vulnerable species (including infraspecific taxa and populations) and exemplary ecological communities.

\section{REPORT HEADER}

\section{Name}

The official CNHP site name, usually corresponding to a local place name or nearby geographic feature.

\section{Site Code}

Unique identifier previously used in the BCD for a site record. 


\title{
IDENTIFIERS
}

\section{Site ID}

Unique identifier for a site.

\section{Site Class}

Value that indicates whether a site is a Potential Conservation Area (PCA) or Network of Conservation Areas (NCA).

Domain values for Site Class are:

PCA

NCA

\section{Site Alias}

Other names commonly associated with the PCA. These can include informal names, old site names, names used by other offices or cooperating organizations, or the original survey site name.

\section{Network of Conservation Areas (NCA)}

A Network of Conservation Areas (NCA) will fit one of the following definitions:

\begin{abstract}
A. A landscape area that encompasses Potential Conservation Areas (PCAs) that share similar species or natural communities and ecological processes. NCAs include unoccupied or unsurveyed areas that are within the same ecological system that the species or natural communities require. NCAs contain PCAs with an obvious repeating pattern (that is, the same species or natural communities are in each associated PCA).
\end{abstract}

B. A mostly intact, lightly fragmented landscape that supports wide-ranging species and large scale disturbances. NCAs include unoccupied or unsurveyed areas that demonstrate the connectivity of the landscape. NCAs contain PCAs that may occur at a variety of ecological scales.

\section{NCA Site ID}

Site ID of the NCA associated with this PCA.

\section{NCA Site Code}

Site code of the NCA associated with this PCA.

\section{NCA Site Name}

Official CNHP site name of the NCA associated with this PCA.

\section{Site Relations}

Comments that explain the relationship between this site and any nested, overlapping, or adjacent sites.

\section{$\underline{\text { LOCATORS }}$}

\section{Nation}

State 


\section{Latitude}

Degrees, Minutes, Seconds. Datum is NAD 27. Calculated in GIS.

\section{Longitude}

Degrees, Minutes, Seconds. Datum in NAD 27. Calculated in GIS.

USGS 7.5 Minute Quadrangle

Calculated in GIS.

Quad Code

Quad Name

\section{County}

Calculated in GIS.

Watershed Code

8 digit U.S.G.S. hydrological unit code. Calculated in GIS.

Watershed Name

U.S.G.S. watershed name. Calculated in GIS.

Township/Range/Section (TRS) - Public Land Survey System

Calculated in GIS.

Township/Range

Section

Meridian

TRS Note

Site Directions [provided with Level 1 data only]

Specific directions to the site provided by the designer or version author.

\section{SITE DESCRIPTION}

\section{Minimum Elevation}

Minimum elevation provided by the designer or version author.

\section{Maximum Elevation}

Maximum elevation provided by the designer or version author.

\section{Site Description}

General visual description (or word picture) of the principal physical and natural features on the site.

\section{Key Environmental Factors}

Description of the driving factors or key environmental variables that are known to exert a major influence on the biota at the site (e.g., seasonal flooding, wind, soil type). 


\section{Climate Description}

General comments concerning climate and weather patterns, wind patterns, seasonal and annual variations, as well as temperature and precipitation patterns characteristic of the site.

\section{Land Use History}

Comments concerning past land uses on this site (such as mining, logging, shifting cultivation, etc.).

\section{Cultural Features}

Comments concerning any historic, cultural, or archaeological features found on the site (e.g., pictographs, petroglyphs, burial mounds, prehistoric artifacts).

\section{SITE DESIGN}

\section{Site Map}

Indicates whether a site boundary was field verified or drawn from desktop references.

Domain values for Site Map are:

$\mathrm{P}$ - partial; drawn from desktop references

$\mathrm{Y}$ - field verified by CNHP personnel

\section{Mapped Date}

Date site boundary was last redrawn.

\section{Designer}

CNHP biologist responsible for drawing the site boundary.

\section{Boundary Justification}

Explanation of the biological rationale used to determine the ecological boundaries for the site.

Primary Area

Area of PCA polygon. Calculated in GIS.

\section{SITE SIGNIFICANCE}

\section{Biodiversity Significance Rank}

Value that indicates the rating that best describes the significance of the site in terms of its biological diversity.

Domain values for Biodiversity Significance are:

B1: Outstanding Biodiversity Significance

B2: Very high Biodiversity Significance

B3: High Biodiversity Significance

B4: Moderate Biodiversity Significance

B5: General interest/open space

B?: Unknown 


\section{Biodiversity Significance Comments}

Comments that justify the rating assigned for the site in the Biodiversity Significance field.

\section{Other Values Rank}

Value that indicates the rating that best describes the significance of the site in terms of its aesthetic, recreational, open space, and other ecological values; this includes its role in maintaining ecosystem health (e.g., by providing game and wildlife habitat, aquifer recharge functions, erosion control).

Domain values for Other Values are:

V1 - Outstanding values

V2 - High values

V3 - Moderate values

V4 - No known values

V5 - Negative or counter values

V? - Unknown

(null) - Not assessed

\section{Other Values Comments}

Comments that justify the rating assigned for the site in the Other Values field.

\section{Protection Urgency Rank [provided with Level 1 data only]}

Value that indicates the rating that best describes the urgency to protect the site. The urgency for protection action (not to be confused with the urgency for management action) will generally increase with impending threats to the site until legal, political, or other administrative measures are taken.

Domain values for Protection Urgency are:

P1 - Immediately threatened/outstanding opportunity

P2 - Threat/opportunity within 5 years

P3 - Definable threat/opportunity, but not within 5 years

P4 - No threat or special opportunity

P5 - No action to be taken on this site

P? - Unknown

Protection Urgency Comments [provided with Level 1 data only]

Comments that justify the rating assigned for the site in the Protection Urgency field.

\section{Management Urgency Rank [provided with Level 1 data only]}

Value that indicates the rating that best describes the urgency to manage one or more Elements at the site. The urgency for management action (not to be confused with the urgency for legal protection action) requires stewardship intervention in order to maintain EOs at the site. 
Domain values for Management Urgency are:

M1 - Essential within 1 year to prevent loss

M2 - Essential within 5 years to prevent loss

M3 - Needed within 5 years to maintain quality

M4 - Not needed now; no current threats; may need in future

M5 - Not needed; no threats anticipated

M? - Unknown

Management Urgency Comments [provided with Level 1 data only]

Comments that justify the rating assigned for the site in the Management Urgency field.

\section{LAND MANAGEMENT ISSUES}

\section{Land Use Comments}

Description of the current and past land use, improvements, and structures on the site.

\section{Natural Hazard Comments}

Description of the potential natural hazards (e.g., cliffs, caves, waterfalls) on the site, along with any precautions that should be taken by stewards.

\section{Exotics Comments}

Description of potentially damaging exotic (i.e., alien) flora and fauna (e.g., kudzu, honeysuckle, purple loosestrife, periwinkle, English ivy, feral goats, pigs) on the site.

\section{Offsite}

Description of off-site land uses (e.g., farming, logging, grazing, dumping, watershed diversion), and how these uses might affect the site, Elements on the site, and management of the site.

\section{Information Needs}

Summary of the information that is still needed in order to effectively manage the site and Elements on it.

\section{Management Needs [provided with Level 1 Data only]}

Summary of the expected management needs for the site and the Elements on it.

\section{Managed Area Relations [provided with Level 1 Data only]}

Explanation of the site/Managed Area relationship, if a Managed Area has been (or will be) established to protect the site.

\section{Protection Comments [provided with Level 1 Data only]}

Summary of the general level of protection currently afforded the site that indicates the current protection status of component Tracts. 


\title{
ASSOCIATED ELEMENTS OF BIODIVERSITY
}

(Tracked Elements known from the area of a given PCA.)

\begin{abstract}
Element
A biodiversity unit of conservation attention and action for which a Heritage Conservation Status Rank is assigned.

Elements may be recognized at any taxonomic level (although typically are only recognized at the species level and below for organisms, and the Ecological System, Alliance, and Association levels for communities).

Elements may also be recognized for biodiversity units for which there is no systematic hierarchy (e.g., animal assemblages, community Complexes).

Elements may be native or exotic at a particular location and collectively represent the full array of biological and ecological diversity for the geographic area covered. Elements may serve as the targets of Heritage inventory. Typically, these targets include native, regularly occurring vulnerable species (including infraspecific taxa and populations) and exemplary ecological communities.
\end{abstract}

\section{Element State ID}

Unique state identifier for an Element.

\section{State Scientific Name}

State scientific name for an Element having occurrences associated with this PCA.

\section{State Common Name}

State common name for an Element having occurrences associated with this PCA.

\section{Global Rank}

The global element rank that best characterizes the relative rarity or endangerment of the element worldwide. Factors other than the number of occurrences may be considered when assigning a global rank. Global ranks are derived primarily by staff at the Central Heritage Conservation Science Department, unless CNHP has lead responsibility for that element.

Domain values for Global Rank are:

G1 - Globally critically imperiled; typically 5 or fewer occurrences

G2 - Globally imperiled; typically 6 to 20 occurrences

G3 - Globally vulnerable; typically 21 to 100 occurrences

G4 - Globally apparently secure; usually > 100 occurrences

G5 - Globally demonstrably secure although it may be rare in parts of its range

G\#G\# - A range between two of the numeric ranks; indicates uncertainty about the rarity of the element

G? - Unranked; element is not yet ranked globally

GU - Unrankable; not enough information is known

GH - Historically known with hopes of rediscovery

GX - Extinct; unlikely to be rediscovered

T\# - Rank applies to a subspecies or variety

$\mathrm{Q}$ - Taxonomic status is questionable 
C - Element is extant only in captivation or cultivation

GNR - Not ranked globally

\section{State Rank}

The state element rank that best characterizes the relative rarity or endangerment of the element statewide. Factors other than the number of occurrences may be considered when assigning a state rank. State ranks are derived by CNHP staff.

Domain values for State Rank are:

S1 - State critically imperiled; typically 5 or fewer occurrences

S2 - State imperiled; typically 6 to 20 occurrences

S3 - State vulnerable; typically 21 to 100 occurrences

S4 - State apparently secure; usually $>100$ occurrences

S5 - State demonstrably secure

S\#S\# - A range between two of the numeric ranks; indicates uncertainty about the rarity of the element

S? - Unranked; element is not yet ranked in the state

$\mathrm{SU}$ - Unrankable; not enough information is known

$\mathrm{SH}$ - Historically known with hopes of rediscovery

SX - Extinct; unlikely to be rediscovered

SE - An exotic established in the state; native to a nearby region

SA - Accidental; includes species (usually birds or butterflies) recorded once or twice or only at very great intervals, hundreds or thousands of miles outside their usual range

$\mathrm{B}$ - Rank refers to the breeding population of the element

$\mathrm{N}$ - Rank refers to the nonbreeding population of the element

$\mathrm{C}$ - Element is extant only in captivation or cultivation

SNR - Not ranked in the state

\section{Driving Site Rank}

Yes or No, indicates whether this EO is the EO which is driving the biodiversity rank of this PCA. A combination of Global Imperilment Rank, State Imperilment Rank, and EO Rank factors determine if a given EO drives the biodiversity rank of a PCA that supports it.

\section{REFERENCES}

\section{Reference ID}

The identifier for a reference available for this PCA.

\section{Full Citation}

Formal citation for a reference associated with the PCA.

\section{ADDITIONAL TOPICS}

\section{Additional Topics}

Specific comments on any significant additional nonstandard topics that have not been formally addressed by one of the standard fields in this record. 


\section{VERSION}

\section{Version Date}

Date report information for the PCA was last reviewed or updated.

\section{Version Author}

Author of the current version of the transcription in this report. 


\section{Potential Conservation Area (PCA) Report}

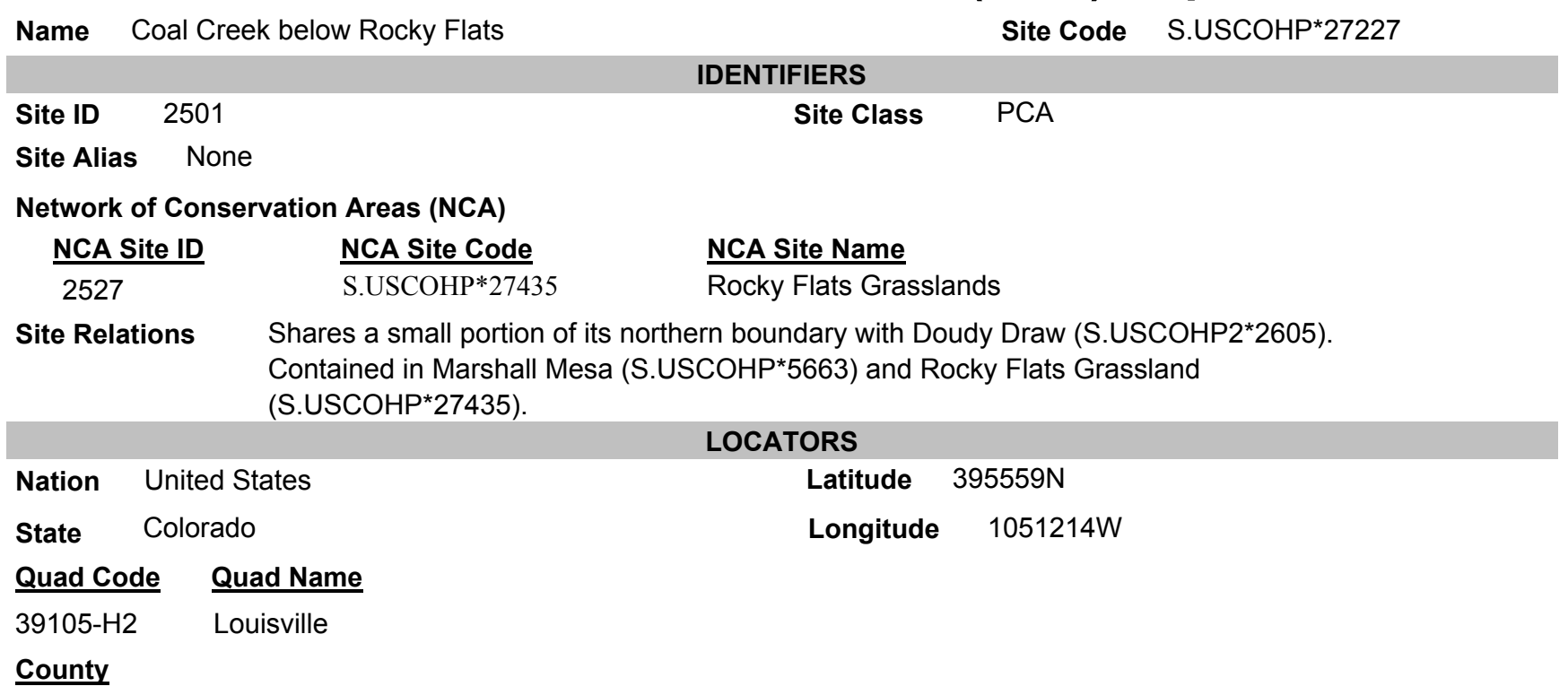

\section{Watershed Code \\ 10190005}

Township/Range

001S070W

001S070W

001S070W

001S070W

001S070W

001S070W

001S070W

001S070W

001S070W

\section{Watershed Name}

St. Vrain

Section
27
26
23
35
34
25
33
24
28

$\frac{\text { Meridian Note }}{6 \mathrm{P}}$
$6 \mathrm{P}$
$6 \mathrm{P}$
$6 \mathrm{P}$
$6 \mathrm{P}$
$6 \mathrm{P}$
$6 \mathrm{P}$
$6 \mathrm{P}$
$6 \mathrm{P}$

\section{SITE DESCRIPTION}

$\begin{array}{lllll}\text { Minimum Elevation } & 5,500.00 & \text { Feet } & 1,676.40 & \text { Meters } \\ \text { Maximum Elevation } & 6,050.00 & \text { Feet } & 1,844.04 & \text { Meters }\end{array}$

\section{Site Description}

This site is located in southeastern Boulder County, immediately north of the boundary with Jefferson County, southwest of the town of Superior. Coal Creek originates in the southwestern corner of Boulder County, near the town of Wondervu. It makes a southward loop into Jefferson County, emerging onto the Rocky Flats terrace, and then turning north to re-enter Boulder County at the northern edge of Rocky Flats. In southern Boulder County, Coal Creek runs through open grasslands below mesas. Historically, the floodplain was likely somewhat wide and meandering, but is now entrenched within low terraces. The creek itself is only 10-20 ft. (3-6 m) across. Water levels are probably never very high in this creek, because there are numerous diversions along the creek. The riparian vegetation is between 164-410 ft. (50-125 m) across, including low shrubs on terraces above the creek. These vegetated terraces may be remnants of when the floodplain was wider, or they may be able to access groundwater recharging from the stream. Within the site, Coal Creek contains a long, continuous stretch of foothills riparian vegetation extending from near the Boulder/Jefferson county line downstream to the town of Superior. The riparian vegetation includes a continuous overstory of mature and regenerating cottonwood trees over dense tall shrubs. Both plains cottonwood ( Populus deltoides) and narrowleaf cottonwood (Populus angustifolia) contribute to the cottonwood overstory, and though the association name is Populus angustifolia / Salix irrorata woodland, this occurrence contains higher cover of plains cottonwood than narrowleaf cottonwood since it is located at a lower elevation than most occurrences. Dominant shrubs within the riparian channel include bluestem willow ( Salix irrorata) and narrowleaf willow (Salix exigua), though upper terraces contain more cerro hawthorn (Crataegus erythropoda) and American plum (Prunus americana). Yellow hawthorn (Crataegus chrysocarpa) has been documented here as well. The surrounding dry grasslands are strongly dominated by non-native species. 


\section{Potential Conservation Area (PCA) Report}

Name Coal Creek below Rocky Flats

Site Code S.USCOHP*27227

\section{Key Environmental Factors}

No Data

\section{Climate Description}

No Data

Land Use History

Historic land use includes grazing, gravel mining, and water diversions.

\section{Cultural Features}

No Data

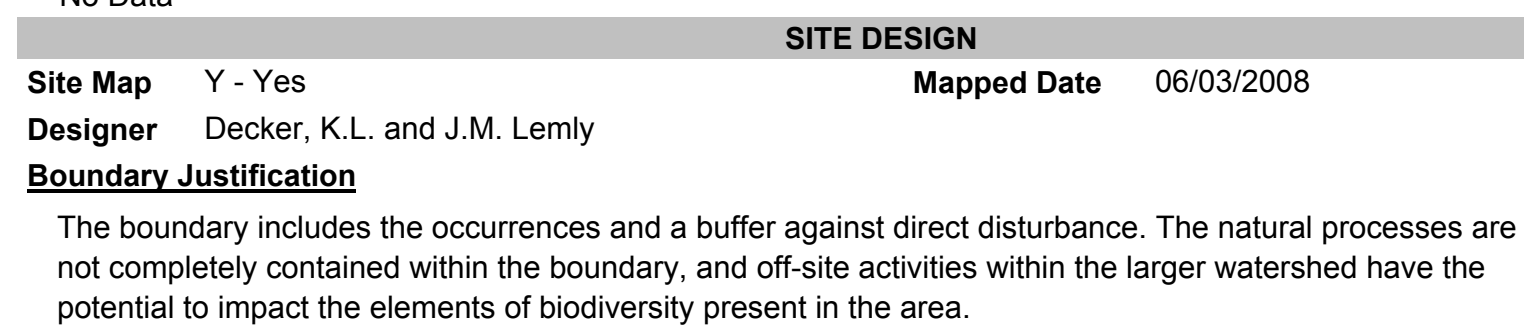

Primary Area

1,504.47 Acres

608.84 Hectares

SITE SIGNIFICANCE
$\begin{aligned} & \text { Biodiversity Significance Rank B3: High Biodiversity Significance } \\ & \text { Biodiversity Significance Comments }\end{aligned}$
This site supports a fair (C-ranked) occurrence of a globally imperiled (G2/S2) Populus angustifolia / Salix
irrorata riparian woodland, two occurrences of the federally Threatened and globally imperiled (G5T2/S1)
Preble's meadow jumping mouse (Zapus hudsonius preblei) in fair condition, and a fair to poor (CD-ranked)
occurrence of the state imperiled (G5/S1B) Bald Eagle (Haliaeetus leucocephalus). Additionally, Boulder
County has documented Ferruginous Hawk (Buteo regalis) nests and an occurrence of the state rare plant
(G5/S2S3) fragrant indigobush (Amorpha nana), but these are not in the CNHP database at this time.

Other Values Rank No Data

Other Values Comments

No Data

Land Use Comments

Cattle grazed the area for decades and likely grazed right into the riparian corridor. In addition, there were gravel mining operations in the floodplain.

\section{Natural Hazard Comments}

No Data

\section{Exotics Comments}

The upland grasslands are strongly dominated by non-native hay grasses and invasive weeds e.g., Kentucky bluegrass (Poa pratensis), timothy (Phleum pratense), orchard grass (Dactylis glomerata), cheatgrass (Anisantha tectorum), jointed goatgrass (Aegilops cylindrical) and smooth brome (Bromus inermis), as well as the following non-native forbs: Canada thistle (Cirsium arvense), bouncing bet (Saponaria officinalis), and bull thistle (Cirsium vulgare), chicory (Cichoruim intybus), common mullein (Verbascum thaspus), common teasel (Dipsacus fullonum), cut-leaved teasel (Dipsacus laciniatus), diffuse knapweed (Centaurea diffusa), musk thistle (Carduus nutans), poison hemlock (Conium maculatum), Russian olive (Elaeagnus angustifolia), Scotch thistle (Onopordum acanthium), and sulphur cinquefoil (Potentilla recta).

\section{Offsite}

No Data

Information Needs

No Data

\begin{tabular}{|c|c|c|c|c|c|}
\hline \multicolumn{6}{|c|}{ ASSOCIATED ELEMENTS OF BIODIVERSITY } \\
\hline $\begin{array}{l}\text { Element } \\
\text { State ID }\end{array}$ & $\underline{\text { State Scientific Name }}$ & State Common Name & $\begin{array}{l}\text { Global } \\
\text { Rank }\end{array}$ & $\begin{array}{l}\text { State } \\
\text { Rank }\end{array}$ & $\begin{array}{l}\text { Driving } \\
\text { Site Rank }\end{array}$ \\
\hline 24827 & Populus angustifolia / Salix irrorata Woodland & Foothills Riparian Woodland & G2 & $\mathrm{S} 2$ & Yes \\
\hline
\end{tabular}

Copyright $\odot$ 2010. Colorado State University. Colorado Natural Heritage Program. All Rights Reserved. 


\section{Potential Conservation Area (PCA) Report}

$\begin{array}{cc}\text { Name } & \text { Coal Creek below Rocky Flats } \\ 21289 & \text { Zapus hudsonius preblei } \\ 21289 & \text { Zapus hudsonius preblei } \\ 21249 & \text { Haliaeetus leucocephalus }\end{array}$

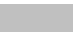

Reference ID

195190

\section{Full Citation}

Neid, S., J. Lemly, K. Decker and D. Culver. 2009. Final Report: Survey of Critical Biological Resources in Boulder County 2007-2008. Colorado Natural Heritage Program, Fort Collins, CO.

Site Code S.USCOHP ${ }^{*} 27227$

Meadow Jumping Mouse Subsp

G5T2

S1

Meadow Jumping Mouse Subsp

G5T2

S1

No

Bald Eagle

G5

S1B,S3N

No

REFERENCES

\section{ADDITIONAL TOPICS}

\section{Additional Topics \\ No Data}

$\begin{array}{ll}\text { Version Date } & \text { 06/03/2008 } \\ \text { Version Author } & \text { Decker, K.L. and J.M. Lemly }\end{array}$

VERSION

Version Date

$06 / 03 / 2008$

Decker, K.L. and J.M. Lemly 


\section{Potential Conservation Area (PCA) Report}

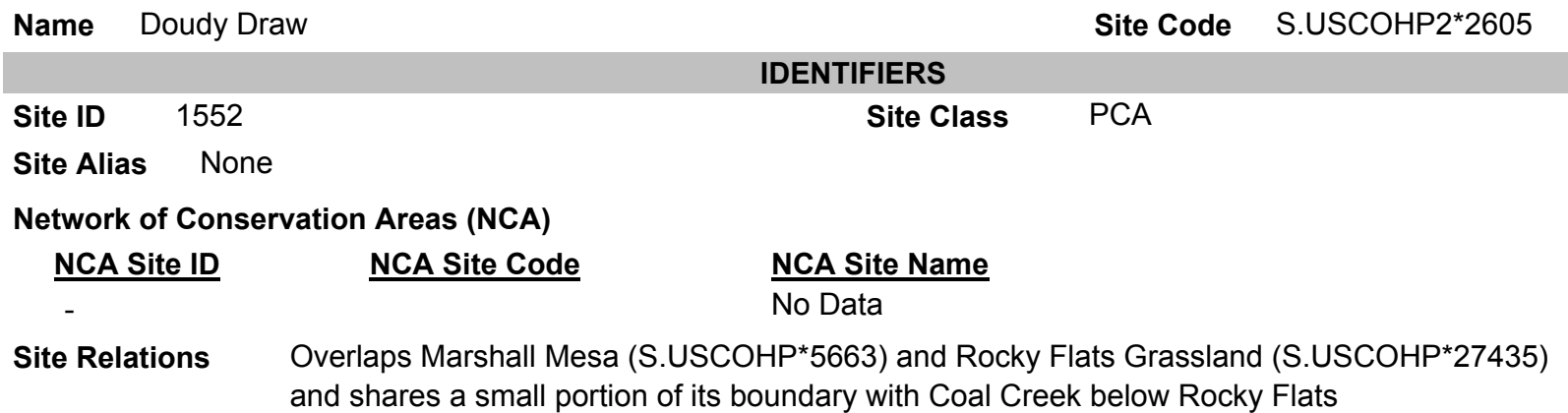

and shares a small portion of its boundary with Coal Creek below Rocky Flats

(S.USCOHP ${ }^{\star 27227) . ~}$

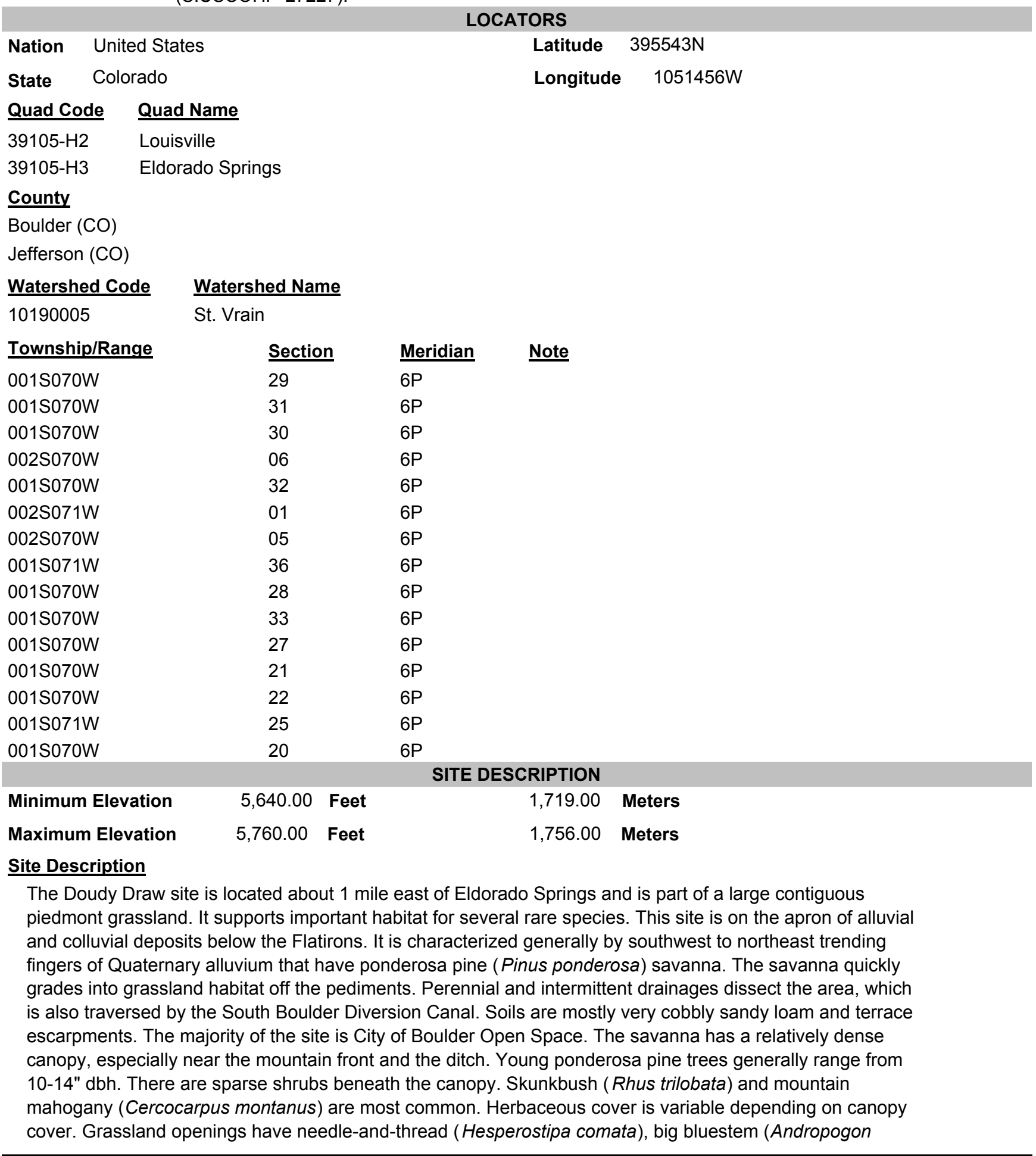

Copyright $\odot$ 2010. Colorado State University. Colorado Natural Heritage Program. All Rights Reserved. 


\section{Potential Conservation Area (PCA) Report}

Name Doudy Draw

Site Code S.USCOHP2*2605

gerardii), blue wildrye (Elymus glaucus), squirreltail (Elymus elymoides), and others. Forbs are frequent but diversity is relatively low. The grasslands below the savanna are on the mesa tops and intervening valleys.

Grasses are diverse and include big bluestem and prairie dropseed (Sporobolus heterolepis) in a mosaic with needle-and-thread (Hesperostipa comata), western wheatgrass (Pascopyrum smithii), mountain muhly (Muhlenbergia montana), and little bluestem (Schizachyrium scoparium) plant associations. Forb diversity is high with porter aster (Aster porteri), buckwheat (Eriogonum umbellatum), false goldenaster (Heterotheca villosa), small sunflower (Helianthus pumilus), and soapweed (Yucca glauca) being common. Shrubs like skunkbush, chokecherry (Prunus virginiana), American plum (Prunus americana), hawthorn (Crataegus erythropoda), and prickly rose (Rosa sayi), form inclusions or scattered copses in the grassland and on the edge of the savanna, often near seeps. Non-natives are prevalent, especially annuals like cheatgrass (Bromus tectorum) and alyssum (Alyssum parviflorum). Mesa tops are fairly unweedy except for early spring occurrences of Alyssum, and areas of dalmation toadflax (Linaria dalmatica). Valley bottoms are somewhat weedy with smooth brome (Bromus inermis), cheatgrass, chicory (Cichorium intybus), and knapweed (Centaurea diffusa). This site contains habitat for northern leopard frog (Rana pipiens). It also provides nest sites and foraging area for Northern Goshawk (Accipiter gentilis), Peregrine Falcon (Falco peregrinus), and Northern Pygmy-owl (Glaucidium gnoma). Bats use the site including fringed myotis (Myotis thysanodes), and Townsend's big-eared bat (Plecotus townsendii). A prairie dog (Cynomys ludovicianus) colony is within the site.

\section{Key Environmental Factors}

Quaternary alluvium

\section{Climate Description}

Annual precipitation is $15-20$ inches. Mean annual air temperature is $48-52$ degrees $F$., and the frost-free season is about $140-155$ days.

\section{Land Use History}

Doudy Draw had one of the original settlements of Boulder City before Colorado gained statehood. It was grazed and farmed for hay and wheat.

\section{Cultural Features}

No Data

\begin{tabular}{|c|c|c|}
\hline \multicolumn{3}{|c|}{ SITE DESIGN } \\
\hline Site Map & Mapped Date & $10 / 29 / 2008$ \\
\hline Designer & Neid, S.L. & \\
\hline Boundary & ustification & \\
\hline
\end{tabular}
Primary Area
3,663.43 Acres
1,482.54 Hectares

\section{SITE SIGNIFICANCE}

\section{Biodiversity Significance Rank B2: Very High Biodiversity Significance \\ Biodiversity Significance Comments}

The site supports a good (B-ranked) occurrence of the globally imperiled (G2/S1S2) Andropogon gerardii Sporobolus heterolepis xeric tallgrass prairie, a good to fair (BC-ranked) occurrence of a globally critically imperiled (G1G2/S1S2) Hesperostipa comata Great Plains mixed grass prairie and a good (B-ranked) occurrence of the globally imperiled (G2/S2?) Pinus ponderosa / Cercocarpus montanus / Andropogon gerardii foothills ponderosa pine scrub woodland. Rare invertebrates include two good (B-ranked) occurrences of the globally vulnerable (G3/S2S3) mottled dusky wing (Erynnis martialis), a good (B-ranked) occurrence of the globally vulnerable (G3G4/S2) Ottoe skipper (Hesperia ottoe) and a good (B-ranked) occurrence of the globally vulnerable (G3/S2) Arogos skipper (Atrytone arogos). Rare plants include a poor (D-ranked) occurrence of the globally imperiled (G2G3/S2) and Federally Threatened Ute ladies' tresses (Spiranthes diluvialis), a good (B-ranked) occurrence of the state rare (G5/S2) prairie violet ( Viola pedatifida) and extant occurrences of the state rare (G5/S1) Rocky Mountain sedge ( Carex saximontana), the state rare (G5/S2) frostweed (Crocanthemum bicknellii) and the state rare (G5/S2S3) dwarf wild indigo (Amorpha nana). Preble's meadow jumping mouse (Zapus hudsonius preblei) (G5T2/S1) has been documented in poor condition, but is not contained in the boundary and not a target for this particular site.
Other Values Rank
V1 - Outstanding values 


\section{Potential Conservation Area (PCA) Report}

Name Doudy Draw

Site Code S.USCOHP2*2605

\section{Other Values Comments}

Open space recreation including jogging, hiking, cycling, horseback riding is common. General wildlife habitat exists for bears, mountain lions, and especially birds. Observed many bird watchers in area during the summer months. Suitable for homesites. Many homesites are adjacent to open space boundaries and on South Boulder Creek.

\section{LAND MANAGMENT ISSUES}

\section{Land Use Comments}

No Data

\section{Natural Hazard Comments}

No Data

\section{Exotics Comments}

Non-native species include smooth brome (Bromus inermis), bull thistle (Cirsium vulgare), Canada thistle (Cirsium arvense), musk thistle (Carduus nutans), leafy spurge (Euphorbia esula), myrtle spurge (Euphorbia myrsinites), cheatgrass (Bromus tectorum), Dalmation toadflax (Linaria dalmatica), diffuse knapweed (Centaurea diffusa), jointed goatgrass (Aegilops cylindrica), and St. Johnswort (Hypericum perforatum). Russian olive (Elaeagnus angustifolia) and houndstongue (Cynoglossum officinale) occur in the drainage bottoms.

\section{Offsite}

Highway 170 (Eldorado Springs Rd) is to the north. Housing developments are to the northeast and southwest (along South Boulder Creek). An electrical substation is immediately adjacent to the west. Eldorado Springs State Park is to the west which receives a high volume of traffic during the summer months.

\section{Information Needs}

A 1984 field survey located a globally rare sedge, Carex oreocharis. More field work is needed to search for this plant.

\begin{tabular}{|c|c|c|c|c|c|}
\hline \multicolumn{6}{|c|}{ ASSOCIATED ELEMENTS OF BIODIVERSITY } \\
\hline $\begin{array}{l}\text { Element } \\
\text { State ID } \\
\end{array}$ & $\underline{\text { State Scientific Name }}$ & $\underline{\text { State Common Name }}$ & $\begin{array}{l}\text { Global } \\
\text { Rank }\end{array}$ & $\begin{array}{l}\text { State } \\
\text { Rank }\end{array}$ & $\begin{array}{l}\text { Driving } \\
\text { Site Rank }\end{array}$ \\
\hline 17998 & Spiranthes diluvialis & Ute ladies' tresses & G2G3 & S2 & No \\
\hline 18073 & Viola pedatifida & prairie violet & G5 & S2 & No \\
\hline 18073 & Viola pedatifida & prairie violet & G5 & S2 & No \\
\hline 19678 & Erynnis martialis & Mottled Dusky Wing & G3 & S2S3 & No \\
\hline 20956 & Amorpha nana & dwarf wild indigo & G5 & $\mathrm{S} 2 \mathrm{~S} 3$ & No \\
\hline 24587 & $\begin{array}{l}\text { Pinus ponderosa / Cercocarpus montanus / } \\
\text { Andropogon gerardii Wooded Herbaceous } \\
\text { Vegetation }\end{array}$ & $\begin{array}{l}\text { Foothills Ponderosa Pine Scrub } \\
\text { Woodlands }\end{array}$ & G2 & S2? & Yes \\
\hline 24703 & $\begin{array}{l}\text { Hesperostipa comata Colorado Front Range } \\
\text { Herbaceous Vegetation }\end{array}$ & Great Plains Mixed Grass Prairie & G1G2 & S1S2 & Yes \\
\hline 24483 & $\begin{array}{l}\text { Andropogon gerardii - Sporobolus heterolepis } \\
\text { Western Foothills Herbaceous Vegetation }\end{array}$ & Xeric Tallgrass Prairie & G2 & S1S2 & Yes \\
\hline 22544 & Carex saximontana & Rocky Mountain sedge & G5 & S1 & No \\
\hline 19893 & Hesperia ottoe & Ottoe Skipper & G3G4 & S2 & No \\
\hline 19678 & Erynnis martialis & Mottled Dusky Wing & G3 & $\mathrm{s} 2 \mathrm{~S} 3$ & No \\
\hline 16895 & Atrytone arogos & Arogos Skipper & G3 & S2 & No \\
\hline 21235 & Crocanthemum bicknellii & frostweed & G5 & $\mathrm{S} 2$ & No \\
\hline 21725 & Falco peregrinus anatum & American Peregrine Falcon & G4T4 & S2B & No \\
\hline
\end{tabular}

\section{Reference ID}

195190

161922

\section{Full Citation}

Neid, S., J. Lemly, K. Decker and D. Culver. 2009. Final Report: Survey of Critical Biological Resources in Boulder County 2007-2008. Colorado Natural Heritage Program, Fort Collins, CO.

Pineda, Phyllis M. 1996. Field Survey (Butterflies) to the City of Boulder Open Space and Mountain Parks, Larimer County and Cheesman Reservoir. Field Season 1996. 


\section{Potential Conservation Area (PCA) Report}

\section{ADDITIONAL TOPICS}

\section{Additional Topics}

Original site design by Pague, C.A. 1994-09-12.

$\begin{array}{lcc} & \text { VERSION } \\ \text { Version Date } & 10 / 29 / 2008 & \\ \text { Version Author } & \text { Neid, S.L. }\end{array}$




\section{Potential Conservation Area (PCA) Report}

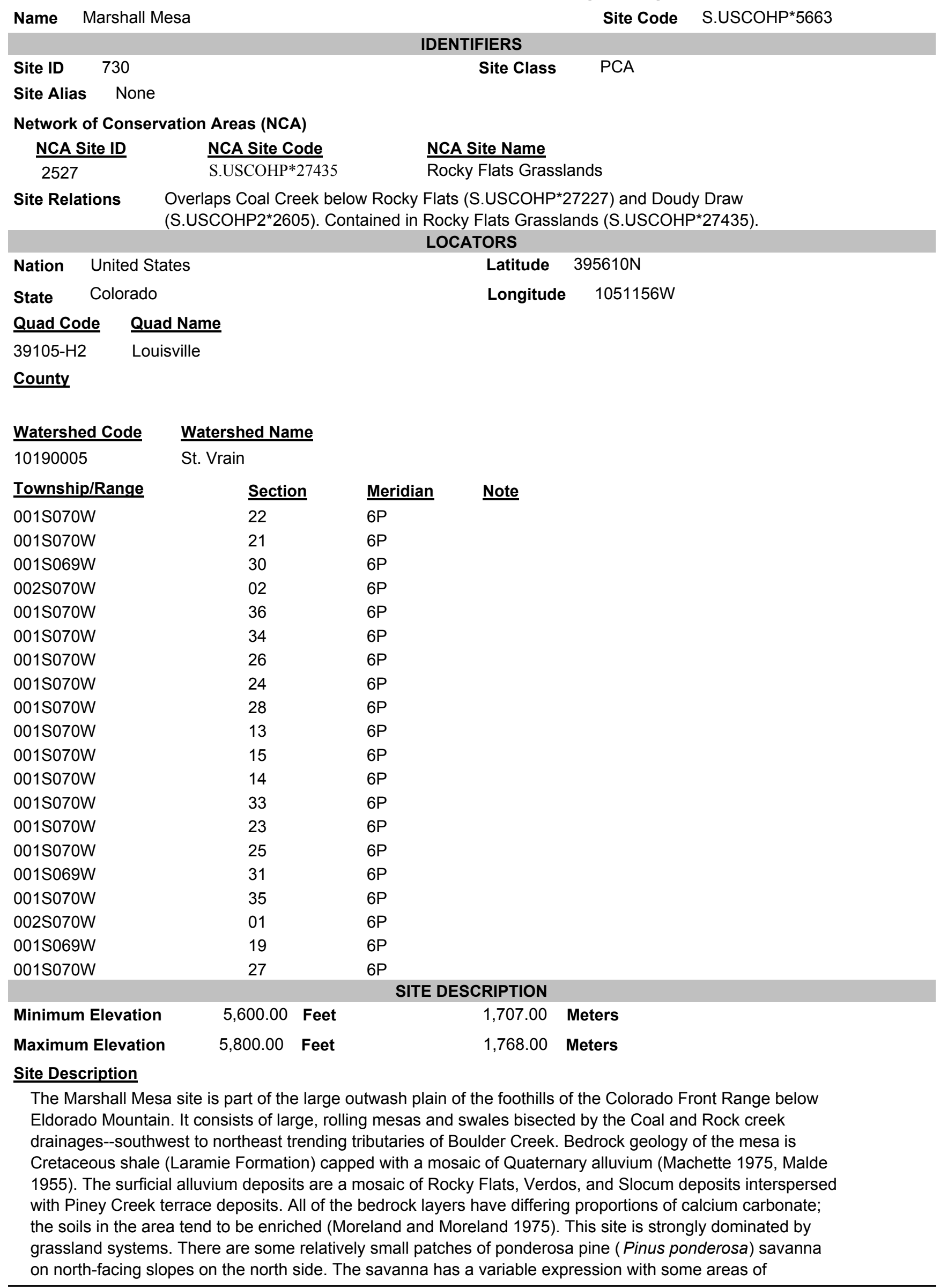

Copyright $\odot$ 2010. Colorado State University. Colorado Natural Heritage Program. All Rights Reserved. 


\section{Potential Conservation Area (PCA) Report}

\section{Name Marshall Mesa}

Site Code S.USCOHP*5663

scattered ponderosa pine and/or Rocky Mountain juniper (Juniperus scopulorum) and others supporting scrubby copses of skunkbush (Rhus trilobata), mountain mahogany (Cercocarpus montanus), ceanothus (Ceanothus herbaceous, C. fendleri), and occasional shrubby cinquefoil (Dasiphora fruticosa). The gravelly, well-drained soils of the mesa tops are covered with grassland mosaic dominated by mid- and tallgrass species. On the west end, the species composition is characterized by big bluestem (Andropogon gerardii), porcupine grass (Hesperostipa spartea), prairie dropseed (Sporobolus heterolepis), sideoats grama (Bouteloua curtipendula), needle-and-thread (Hesperostipa comata), western wheatgrass (Pascopyrum smithii), purple threeawn (Aristida purpurea), junegrass (Koeleria macrantha), mountain muhly (Muhlenbergia montana), little bluestem (Schizachyrium scoparium), and others. Forbs are very diverse and include soapweed (Yucca glauca), wavy-leaved thistle (Cirsium undulatum), scurfpea (Psoralea tenuiflora), blanketflower (Gaillardia aristata), hedgehog cactus (Echinocereus viridiflorus), prickly pear cactus (Opuntia spp.), mariposa lily (Calochortus gunnisonii), fringed sage (Artemesia frigida), blazing star (Liatris punctata), and many others. Dwarf indigo (Amorpha nana) and slimleaf milkweed (Asclepias stenophylla) occur in the grasslands. Farther east along the mesas, the tallgrass species become much less common and the matrix grassland is characterized by needle-and-thread. Within this area are small patches of New Mexico feathergrass (Hesperostipa neomexicana) on north-facing slope crests. These grasslands support some of the highest concentrations of grassland nesting birds in the Piedmont; while more common elsewhere in the state, this site reflects a substantial eedge-of-range habitat for these species. Within the grassland are large prairie dog towns. These towns can be very weedy and dominated by bindweed (Convolvulus arvensis). However, they also support burrowing owl (Athene cunicularia). This also supports northern leopard frog (Rana pipiens) and wavy-leaf stickleaf (Nuttallia sinuata). The portion of this site that overlaps with Doudy Draw historically contained ottoe skipper (Hesperia ottoe), crossline skipper (Polites origenes), Arogos skipper (Atrytone arogos), and dusted skipper (Atrytonopsis hianna).

\section{Key Environmental Factors}

Outwash mesa of Quaternary alluvium

\section{Climate Description}

Annual precipitation is 12 to 18 inches. Mean annual air temperature is $48-52$ degrees $F$., and the frost-free season is about $140-155$ days.

\section{Land Use History}

Grazing, coal mining.

\section{$\underline{\text { Cultural Features }}$}

No Data

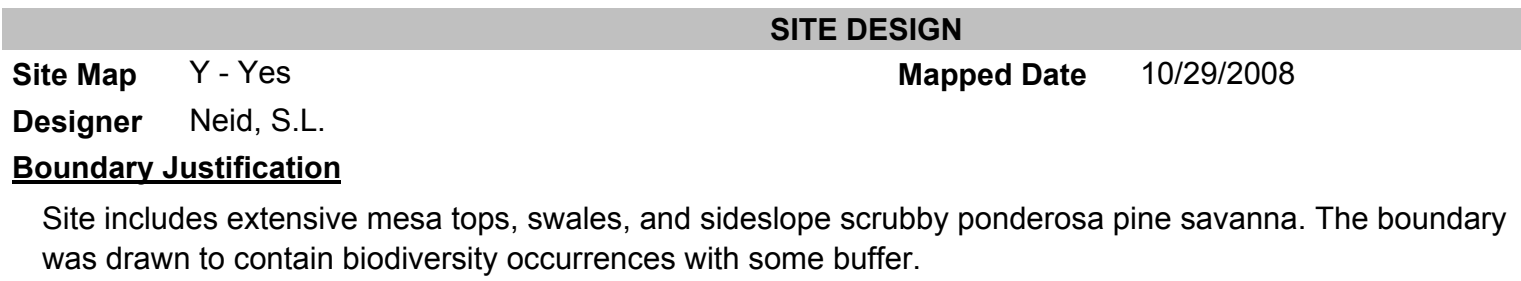

\section{Primary Area \\ 6,760.28 Acres \\ 2,735.80 Hectares}

\section{SITE SIGNIFICANCE}

\section{Biodiversity Significance Rank B2: Very High Biodiversity Significance}

\section{Biodiversity Significance Comments}

The site supports an excellent to good (AB-ranked) occurrence of the globally imperiled (G2?/S2) Andropogon gerardii - Schizachyrium scoparium xeric tallgrass prairie, a good and a good to fair (BC-ranked) occurrence of the globally vulnerable (G3/S3) Hesperostipa neomexicana Great Plains mixed grass prairie, a fair (C-ranked) occurrence of the state rare (G5/S2) prairie violet ( Viola pedatifida), a poor (D-ranked) occurrence of the state rare (G5/S2S3) dwarf wild indigo (Amorpha nana) and an extant occurrence of the state rare (G4/S3) black-tailed prairie dog (Cynomys ludovicianus).

\section{Other Values Rank No Data \\ Other Values Comments \\ No Data}

LAND MANAGMENT ISSUES

\section{Land Use Comments} No Data 


\section{Potential Conservation Area (PCA) Report}

Name Marshall Mesa

Site Code S.USCOHP*5663

\section{Natural Hazard Comments}

No Data

\section{Exotics Comments}

Weeds include diffuse knapweed (Centaurea diffusa), cheatgrass (Bromus tectorum), chicory (Cichorium intybus), teasel (Dipsacus fullonum), Dalmation toadflax (Linaria dalmatica), jointed goatgrass (Aegilops cylindrica), musk thistle (Carduus nutans), scotch thistle (Onopordium acanthium), sulfur cinquefoil (Potentilla recta), and bindweed (Convolvulus arvensis).

\section{Offsite}

Housing developments; industrial sites; Superfund waste site; Community and Davidson Ditches bisect property; highways define boundaries of the site.

\section{Information Needs}

\section{No Data}

\begin{tabular}{|c|c|c|c|c|c|}
\hline \multicolumn{6}{|c|}{ ASSOCIATED ELEMENTS OF BIODIVERSITY } \\
\hline $\begin{array}{l}\text { Element } \\
\text { State ID } \\
\end{array}$ & $\underline{\text { State Scientific Name }}$ & State Common Name & $\begin{array}{l}\text { Global } \\
\text { Rank }\end{array}$ & $\begin{array}{l}\text { State } \\
\text { Rank }\end{array}$ & $\begin{array}{l}\text { Driving } \\
\text { Site Rank }\end{array}$ \\
\hline 18073 & Viola pedatifida & prairie violet & G5 & $\mathrm{S} 2$ & No \\
\hline 22673 & $\begin{array}{l}\text { Hesperostipa neomexicana Herbaceous } \\
\text { Vegetation }\end{array}$ & Great Plains Mixed Grass Prairie & G3 & S3 & No \\
\hline 22673 & $\begin{array}{l}\text { Hesperostipa neomexicana Herbaceous } \\
\text { Vegetation }\end{array}$ & Great Plains Mixed Grass Prairie & G3 & S3 & No \\
\hline 17796 & Cynomys ludovicianus & Black-tailed Prairie Dog & G4 & S3 & No \\
\hline 24870 & $\begin{array}{l}\text { Andropogon gerardii - Schizachyrium scoparium } \\
\text { Western Great Plains Herbaceous Vegetation }\end{array}$ & Xeric Tallgrass Prairie & G2? & $\mathrm{S} 2$ & Yes \\
\hline 20956 & Amorpha nana & dwarf wild indigo & G5 & S2S3 & No \\
\hline
\end{tabular}

\section{REFERENCES}

\section{Reference ID}

198280

198281

198282

195190

161922

\section{Full Citation}

Machette, M.N. 1975. Geologic map of the Lafayette quadrangle, Adams, Boulder, and Jefferson counties, Colorado. U.S. Government Printing Office, Washington, D.C.

Malde, H.E. 1955. Surficial geology of the Louisville quadrangle, Colorado. Geological Survey Bulletin 996-E. U.S. Government Printing Office, Washington, D.C. Moreland, D.C. and Moreland, R.E. 1975. Soils Survey of the Boulder County Area, Colorado. United States Department of Agriculture, Soil Conservation Service, in cooperation with the Colorado Agricultural Experiment Station. Soil Conservation Service, Washington, D.C.

Neid, S., J. Lemly, K. Decker and D. Culver. 2009. Final Report: Survey of Critical Biological Resources in Boulder County 2007-2008. Colorado Natural Heritage Program, Fort Collins, CO.

Pineda, Phyllis M. 1996. Field Survey (Butterflies) to the City of Boulder Open Space and Mountain Parks, Larimer County and Cheesman Reservoir. Field Season 1996.

\section{ADDITIONAL TOPICS}

\section{Additional Topics}

Original site design by Pineda, P.M. 1996-09-23.

$\begin{array}{lcc}\text { Version Date } & \text { VERSION } \\ \text { Version Author } & \text { Neid, S.L. } & \end{array}$




\section{Potential Conservation Area (PCA) Report}

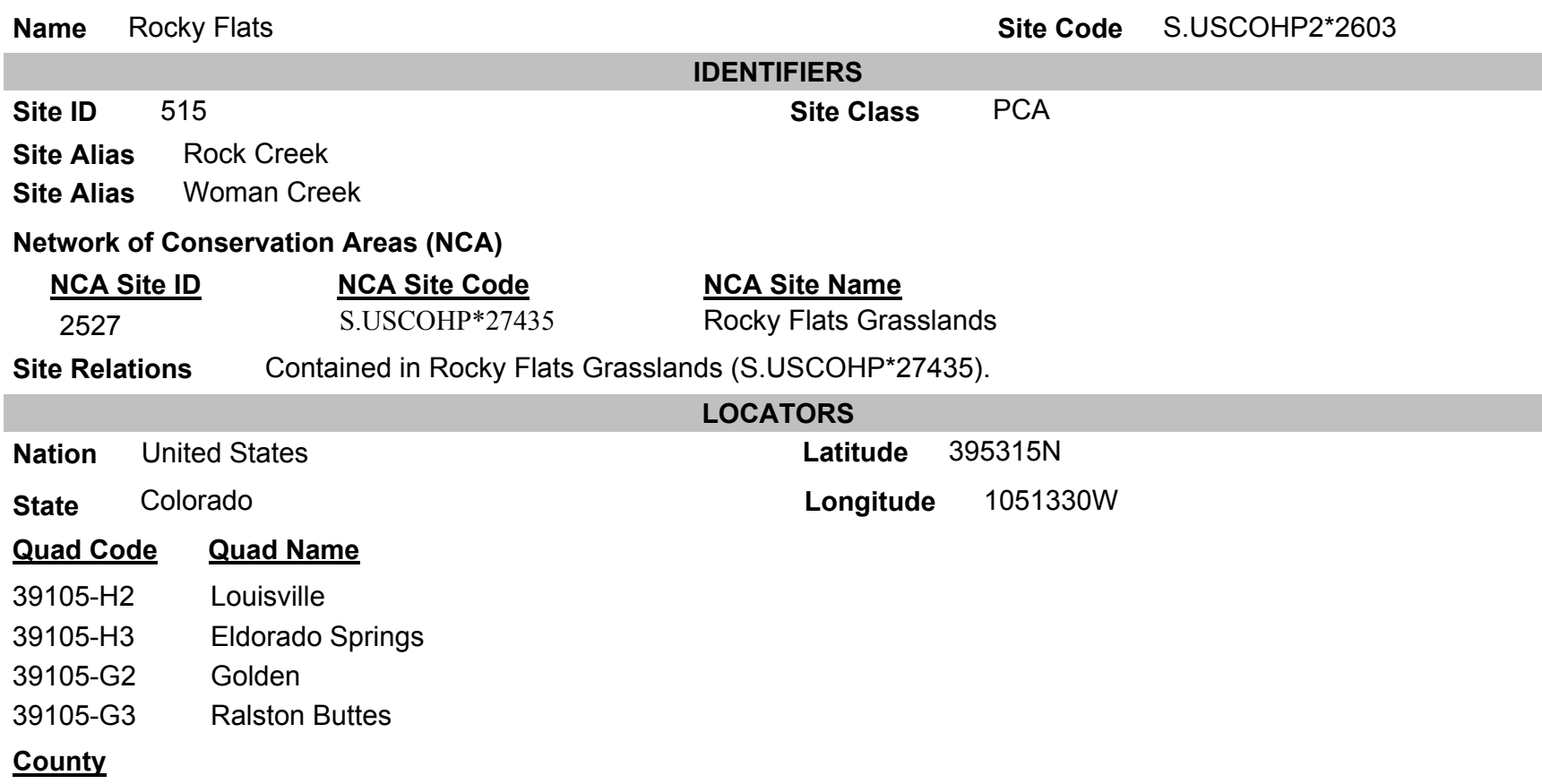

Watershed Code
10190003
10190004
10190005

Township/Range

001S070W

002S070W

002S070W

002S070W

002S070W

002S070W

002S070W

002S070W

002S070W

002S070W

002S070W

002S070W

002S070W

002S070W

002S070W

002S070W

002S070W

002S070W

\section{Watershed Name \\ Middle South Platte-Cherry Creek \\ Clear \\ St. Vrain}

$\begin{array}{lrlrl}\text { Minimum Elevation } & 5,400.00 & \text { Feet } & \text { SITE DESCRIPTION } & \\ \text { Maximum Elevation } & 6,120.00 & \text { Feet } & 1,646.00 & \text { Meters } \\ & & & 1,865.00 & \text { Meters }\end{array}$

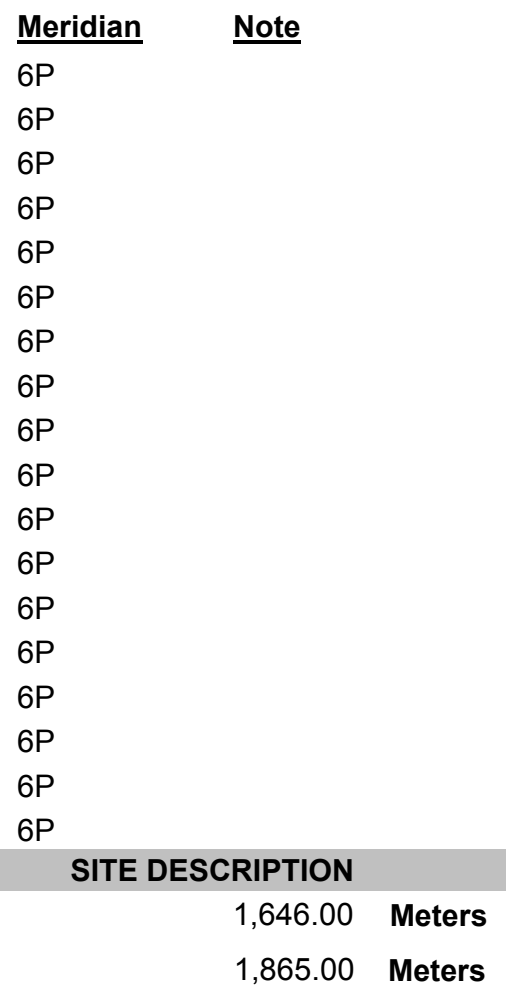

Site Description

The Rocky Flats site occurs on the south and west portions of the Rocky Flats alluvial fan and, to some extent, down into the colluvial valleys that dissect it. Most of the site is located on the Rocky Flats

Environmental Technology Site (RFETS), a former nuclear weapons manufacturing facility overseen by the U.S. Department of Energy. RFETS is listed on the National Priorities List under the Comprehensive Environmental Response, Compensation, and Liability Act (CERCLA). The flora is similar to other alluvial 


\title{
Potential Conservation Area (PCA) Report
}

\author{
Name Rocky Flats \\ Site Code S.USCOHP2*2603 \\ fans in the region, although many of these natural communities are becoming increasingly threatened by \\ urban development. The fauna has been more highly impacted by regional extirpations of some high trophic \\ level mammals, but still retains many common animals and some rarer ones. The site is bounded by Highway \\ 128 on the north, Coal Creek to the west, and the RFETS boundary to the south. The eastern boundary \\ follows a rough line that follows the eastern watershed extent of Rock Creek, curves around to the west of the \\ facility's industrial area, and runs southeast to include the wetland complexes of upper Woman Creek.
}

\section{Key Environmental Factors}

No Data

\section{Climate Description}

15 inches of precip. ann. Prone to high winds, sometimes reaching $80 \mathrm{MPH}$.

\section{Land Use History}

General public has been excluded from most of site for the last 20-40 years. Grazing and gravel mining have been ongoing.

\section{Cultural Features}

Some of the site is regulated by EPA and CDPHE under Superfund.

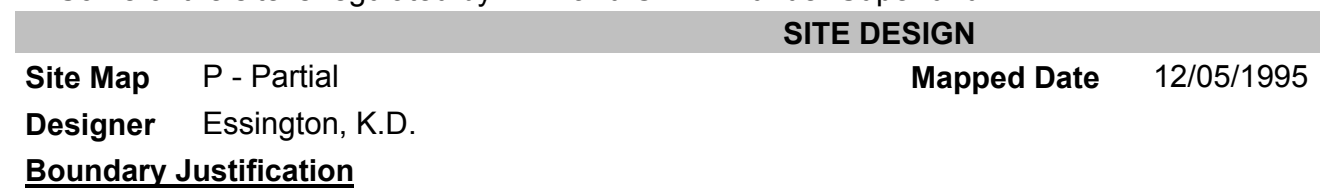

The boundaries include xeric tallgrass prairie, the Great Plains riparian community in Rock Creek, the Preble's meadow jumping mouse occurrence in Rock Creek and upper Woman Creek, and the invertebrate occurrences. The potential extent of xeric tallgrass prairie is documented by Western Aggregates, Inc. (1995) and, while fragmented by roads and gravel pits, is considered one occurrence by CNHP. It stretches from the northwest corner of the site south through section 16 and west for an uncertain distance across Highway 93. Field surveys and monitoring data indicate that the xeric tallgrass prairie community exists on the mesa tops in the southwest corner (section 15) of the RFETS Buffer Zone. Similar grasslands appear to extend beyond the study area, west of Highway 93, indicating that this community occurrence is part of a larger, even more viable system (Western Aggregates 1994). Therefore, CNHP has included this extension in the boundary. With the use of a Series 30 Lasico planimeter, CNHP has determined that the community is at least 2,500 acres. The boundary is also considered a "buffer area" for the rare invertebrates recorded. It is difficult to monitor the range of these animals but this "buffer area" should sufficiently protect their perceived needs by including adequate habitat size. It should be noted that the Rock Creek and Woman Creek watersheds are joined into one site. This is an atypical boundary determination by CNHP and is due to two factors. First, the xeric tallgrass prairie occurrence, equally covers both watersheds. Second, is the understanding that hydrologic inputs to Woman Creek are probably from shallow groundwater recharge in the pediments of sections 16 and 15, east of the sandstone hogback that runs north-south through the area (U.S. Department of Energy 1992, U.S. Department of Energy 1994d). Although the Woman Creek channel has been historically used for water conveyance to downstream users, and thereby contributing to flow patterns and possibly augmenting Preble's meadow jumping mouse habitat, this practice will not continue due to the construction of the Kinnear Pipeline (Hill pers. comm. 1995). It is critical that, in order to ensure natural surface water flow and continued viability of the Preble's meadow jumping mouse occurrence in Woman Creek, the groundwater recharge area be included.

Primary Area $4,016.08$ Hectares
SITE SIGNIFICANCE
$\begin{aligned} & \text { Biodiversity Significance Rank } \quad \text { B2: Very High Biodiversity Significance } \\ & \text { Biodiversity Significance Comments }\end{aligned}$
This site supports a good (B-ranked) occurrence of a globally imperiled (G2?/S2) xeric tallgrass prairie
(Andropogon gerardii - Schizachyrium scoparium) and a fair (C-ranked) occurrence of the globally imperiled
(G5T2/S1) and federally Threatened Preble's meadow jumping mouse (Zapus hudsonius preblei). Unique
invertebrate occurrences include a fair (C-ranked) occurrence of the globally imperiled (G2G3/S2) hops
feeding azure (Celastrina humulus), a fair (C-ranked) occurrence of the globally vulnerable (G3G4/S2)
Ottoe skipper (Hesperia ottoe) and a fair (C-ranked) occurrence of the globally vulnerable (G3/S2) Arogos
skipper (Atrytone arogos).

Other Values Rank No Data 


\section{Potential Conservation Area (PCA) Report}

\section{Name Rocky Flats}

Site Code S.USCOHP2*2603

\section{Other Values Comments}

The Colorado Bird Observatory ( $\mathrm{CBO}$ ), recognizes several high priority species that use the site. These species include Lark Bunting (Calamospiza melanocorys), Ferruginous Hawk (Buteo regalis), MacGillivray's Warbler (Opornis tolmiei), Brewer's Sparrow (Spizella brewerii), and several others (U.S. Department of Energy 1995a). Although many observations of these species appear to be casual, it should not be overlooked that the area could provide essential migratory stopover habitat for these and more common species. EG\& G estimated breeding population density for Grasshopper Sparrows in the prairie community (as it occurs on RFETS) to be 0.65 birds/hectare, or roughly 120 birds (U.S. Department of Energy 1995c). This species is a further indicator of the special nature not only of the site in general, but the xeric tallgrass prairie in particular. A marginal occurrence (not tracked by CNHP) of a Great Plains riparian community occurs. It is characterized by a diverse mixture of plains cottonwood, peach- leaved willow, and coyote willow (Populus deltoides / Salix amygdaloides - Salix exigua) with an understory of various low shrubs such as leadplant (Amorpha fruticosa) and snowberry (Symphoricarpos occidentalis). This community is rare and declining in its native conditions throughout the high plains of Colorado, Nebraska, and Kansas. Threats to this community type are primarily water development, use and management. However, exotic species, such as leafy spurge (Euphorbia esula) and purple loosestrife (Lythrum elata) are increasing problems. Despite the generally xeric nature of the area, several wetlands occur, mostly in the upper Woman Creek drainage, but also on north aspect slopes in Rock Creek. These wetland occurrences are also not among the best examples of common associations in the state due to their relatively restricted size. They don't rank as high priorities for their Natural Heritage values with respect to plant associations. This view is bolstered by recognition that the seep sites in upper Woman Creek may be enhanced by anthropogenic water impoundments (i.e. Rocky Flats Lake) to the west (U.S. Army Corps of Engineers 1994). The wetlands do, however, potentially serve other important functions and values, as do wetlands everywhere. Perhaps most important, we do not yet understand how wetland mosaics present support local populations of Preble's meadow jumping mouse. These wetlands may also retain nutrients, sediment, and metals in the water, provide food chain support both within the basin and downstream, and provide forage, cover, and nesting habitat for wildlife (Mitch and Gosselink 1994). The hillside seeps in Rock Creek support a unique tall shrubland complex (Kettler et al. 1994). Dominated by hawthorn (Crataegus erythropoda), chokecherry (Prunus virginiana), and some western snowberry (Symphoricarpos occidentalis), CNHP has tentatively classified it as Crataegus erythropoda - Prunus virginiana - Symphoricarpos occidentalis plant association. An additional unusual shrub community occurs within Rock Creek, and to some extent in Woman Creek. It is dominated by leadplant (Amorpha fruticosa). It occurs in floodplains of the stream channels, laterally upgradient from the Great Plains riparian community. Like the Great Plains riparian community, it is believed that this shrubland has been highly impacted by water management and exotic species intrusion, but historical records and trends are lacking.

\section{Land Use Comments No Data \\ Natural Hazard Comments \\ No Data \\ Exotics Comments No Data}

\section{Offsite}

As part of a larger, landscape-level, open space contingent, it is likely that the site is an important contributor to healthy predator-prey relationships. The size, current isolation, and relatively high quality of the area supports potentially viable population of numerous species that are typical of the natural communities at RFETS. This supports biodiversity at the landscape level by preventing biogeographic (or island) effects prevalent in many natural areas (Macarthur and Wilson 1967). This is likely to be important to some common species, but particularly so for more motile and rare species.

\section{Information Needs}

The undocumented nature of Carex oreocharis in Colorado suggests to CNHP that its occurrence in the site should be protected and studied further. A wider search designed to confirm or deny other occurrences throughout its range may be in order. Invertebrate Management Recommendations: Studies have shown that the Colorado Piedmont is one of the country's four most important ecoregions for the conservation of the diversity of butterflies (Opler 1994). Butterflies can be easily monitored and may be good indicators of 


\section{Potential Conservation Area (PCA) Report}

Name Rocky Flats

Site Code S.USCOHP2*2603

environmental changes. This is especially true for imperiled species, or those associated with rare habitats. To this end, CNHP encourages the Department of Energy to conduct additional studies of the species identified in this report and for other rare species known from the general area that were not confirmed. These unconfirmed elements include the rare Ottoe skipper, a globally vulnerable species recorded in xeric tallgrass prairie 3 miles southwest of the study area.

\begin{tabular}{|c|c|c|c|c|c|}
\hline \multicolumn{6}{|c|}{ ASSOCIATED ELEMENTS OF BIODIVERSITY } \\
\hline $\begin{array}{l}\text { Element } \\
\text { State ID } \\
\end{array}$ & State Scientific Name & State Common Name & $\begin{array}{l}\text { Global } \\
\text { Rank }\end{array}$ & $\begin{array}{l}\text { State } \\
\text { Rank }\end{array}$ & $\begin{array}{l}\text { Driving } \\
\text { Site Rank }\end{array}$ \\
\hline 19893 & Hesperia ottoe & Ottoe Skipper & G3G4 & S2 & No \\
\hline 20146 & Celastrina humulus & Hops Feeding Azure & G2G3 & S2 & No \\
\hline 23792 & Aristida basiramea & forktip three-awn & G5 & s1 & No \\
\hline 16895 & Atrytone arogos & Arogos Skipper & G3 & S2 & No \\
\hline 21289 & Zapus hudsonius preblei & Meadow Jumping Mouse Subsp & G5T2 & S1 & No \\
\hline 24870 & $\begin{array}{l}\text { Andropogon gerardii - Schizachyrium scoparium } \\
\text { Western Great Plains Herbaceous Vegetation }\end{array}$ & Xeric Tallgrass Prairie & G2? & S2 & Yes \\
\hline 21289 & Zapus hudsonius preblei & Meadow Jumping Mouse Subsp & G5T2 & S1 & No \\
\hline \multicolumn{6}{|c|}{ REFERENCES } \\
\hline \multicolumn{2}{|c|}{ Reference ID } & & & & \\
\hline- & No Data & & & & \\
\hline
\end{tabular}

\section{Additional Topics}

ADDITIONAL TOPICS

No Data

\section{VERSION}

$\begin{array}{ll}\text { Version Date } & 12 / 05 / 1995 \\ \text { Version Author } & \text { Essington, K.D. }\end{array}$




\title{
Network of Conservation Areas (NCA) Report
}

\author{
Name Rocky Flats Grasslands \\ Site Code S.USCOHP*27435

\begin{tabular}{|c|c|}
\hline \multicolumn{2}{|r|}{ IDENTIFIERS } \\
\hline Site ID & Site Class \\
\hline Site Alias & \\
\hline Site Relations & $\begin{array}{l}\text { This site is designated as a Network of Conservation Areas (NCA) because it delineates a } \\
\text { relatively intact landscape containing many smaller sites that are interrelated. It shares similar } \\
\text { ecological processes with Coal Creek at Rocky Flats (S.USCOHP*7762), Coal Creek below } \\
\text { Rocky Flats (S.USCOHP*27227), Marshall Mesa (S.USCOHP*5663), Rocky Flats } \\
\text { (S.USCOHP2*2603) and Walnut Creek (S.USCOHP4*2453). Overlaps Doudy Draw }\end{array}$ \\
\hline
\end{tabular}

(S.USCOHP2*2605).

\begin{tabular}{|c|c|c|c|}
\hline \multicolumn{4}{|c|}{ LOCATORS } \\
\hline Nation & \multirow{2}{*}{$\begin{array}{l}\text { United States } \\
\text { Colorado }\end{array}$} & Latitude & $395437 N$ \\
\hline State $\quad \mathrm{C}$ & & Longitude & $1051301 \mathrm{~W}$ \\
\hline \multicolumn{4}{|c|}{ Quad Code Quad Name } \\
\hline 39105-G2 & Golden & & \\
\hline 39105-G3 & Ralston Buttes & & \\
\hline $39105-\mathrm{H} 3$ & Eldorado Springs & & \\
\hline $39105-\mathrm{H} 2$ & Louisville & & \\
\hline \multicolumn{2}{|l|}{ County } & & \\
\hline
\end{tabular}

\begin{tabular}{|c|c|}
\hline Watershed Code & Watershed Name \\
\hline 10190003 & Middle South Platte-Cherry Creek \\
\hline 10190005 & St. Vrain \\
\hline 10190004 & Clear \\
\hline
\end{tabular}

\section{Site Directions}

This Network of Conservation Area is bounded to the west by the Front Range foothills and to the east by County Road 17 south of Superior. It is bounded on the north side by Route 170 and Highway 36 in Boulder County and it extends just south of Highway 72 in Jefferson County.

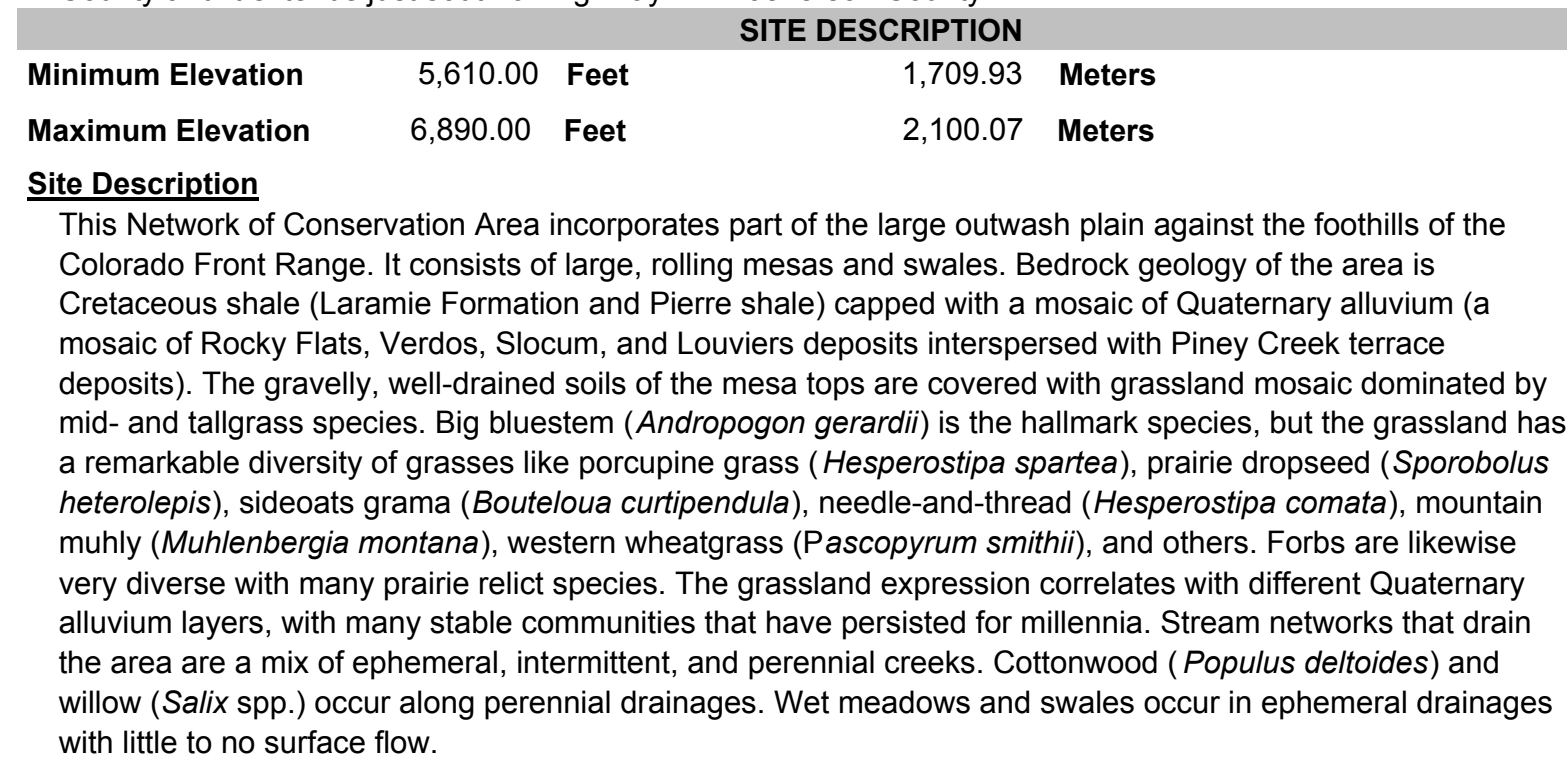

\section{Key Environmental Factors}

Quaternary alluvium layers including Rocky Flat, Louviers, Slocum, Verdos, Piney Creek, post-Piney Creek.

\section{Climate Description}

No Data

\section{Land Use History}

No Data 


\section{Network of Conservation Areas (NCA) Report}

Name Rocky Flats Grasslands

\section{Cultural Features}

No Data

Primary Area 20,844.41 Acres 8,435.47 Hectares

\section{OTHER/PROTECTION/MANAGEMENT RANKS}

\section{Other Values Rank No Data}

Other Values Comments

No Data

\section{Protection Urgency Rank P?: Unknown \\ Protection Urgency Comments}

This NCA has significant area of private lands. Other significant owners include the federal government (Rocky Flats), City of Boulder Open Space and Mountain Parks, and the Colorado State Land Board.

\section{Management Urgency Rank M?: Unknown}

\section{Management Urgency Comments}

Maintaining large, contiguous blocks of native grassland will continue to support the unique grassland biodiversity that occurs. Grazing and fire are management tools for maintaining the pattern of tall- and midgrass mosaic and support the bird biodiversity within the area.

\section{LAND MANAGEMENT ISSUES}

\section{Land Use Comments}

No Data

\section{Natural Hazard Comments}

No Data

\section{Exotics Comments}

No Data

\section{Offsite}

No Data

Information Needs

No Data

Management Needs

No Data

Managed Area Relations

No Data

\section{Protection Comments}

No Data 


\section{Network of Conservation Areas (NCA) Report}

\begin{tabular}{|c|c|c|}
\hline \multicolumn{2}{|c|}{ Name Rocky Flats Grasslands } & \multirow{2}{*}{$\begin{array}{r}\text { Site Code S.USCO } \\
\text { PCA Biological Diversity Significance }\end{array}$} \\
\hline PCA Site ID & PCA Site Name & \\
\hline 730 & Marshall Mesa & B2: Very High Biodiversity Significance \\
\hline 515 & Rocky Flats & B2: Very High Biodiversity Significance \\
\hline 2501 & Coal Creek below Rocky Flats & B3: High Biodiversity Significance \\
\hline 1595 & Coal Creek at Rocky Flats & B3: High Biodiversity Significance \\
\hline 1034 & Walnut Creek & B5: General Biodiversity Interest \\
\hline
\end{tabular}

\section{Reference ID}

195190

\section{Full Citation}

Neid, S., J. Lemly, K. Decker and D. Culver. 2009. Final Report: Survey of Critical Biological Resources in Boulder County 2007-2008. Colorado Natural Heritage Program, Fort Collins, CO.

\section{Additional Topics \\ No Data}

\section{ADDITIONAL TOPICS}

$\begin{array}{ll}\text { Lead Responsibility } & \text { CNHP- } \\ \text { Version Date } & 11 / 14 / 2008 \\ \text { Version Author } & \text { Neid, S.L. }\end{array}$


July 23, 2010

Knowledge to Go Places

\author{
Jenny Gerson \\ Ecologist \\ Walsh Environmental Scientists and Engineers, LLC \\ An Ecology \& Environment company \\ 4888 Pearl East Circle, Ste. 108 \\ Boulder, CO 80301-2475
}

Dear Jenny:

The Colorado Natural Heritage Program (CNHP) is in receipt of your request for information regarding National Wind Technology Center. In response, I have searched our Biodiversity Tracking and Conservation System (BIOTICS) for natural heritage elements (occurrences of significant natural communities and rare, threatened or endangered plants and animals) documented from the vicinity of the area specified in your request, specifically within a two-mile radius of the site National Wind Technology Center boundary shapefile Walsh Environmental provided to CNHP for the purposes of this request.

The enclosed report describes natural heritage resources known from this area and gives location (by Township, Range, and Section), precision information, and the date of last observation of the element at that location. This report includes elements known to occur within the specified project site, as well as elements known from similar landscapes near the site. Please note that "precision" reflects the resolution of original data. For example, an herbarium record from " 4 miles east of Colorado Springs" provides much less spatial information than a topographic map showing the exact location of the occurrence. "Precision" codes of

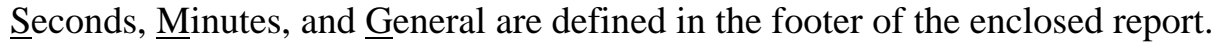

The report also outlines the status of known elements. We have included status according to Natural Heritage Program methodology and legal status under state and federal statutes. Natural Heritage ranks are standardized across the Heritage Program network, and are assigned for global and state levels of rarity. They range from " 1 " for critically imperiled or extremely rare elements, to " 5 " for those that are demonstrably secure.

You may notice that some occurrences do not have sections listed. Those species have been designated as "sensitive" due to their rarity and threats by human activity. Peregrine falcons, for example, are susceptible to human breeders removing falcon eggs from their nests. For these species, CNHP does not normally provide location information beyond township and range. Please contact us should you require more detailed information for sensitive occurrences.

There are multiple CNHP designated Potential Conservation Areas (PCAs) and one Network of Conservation Areas (NCA) located within your project area (see enclosed PCA/NCA site reports and shapefiles). In order to successfully protect populations or occurrences, it is necessary to delineate conservation areas. These conservation areas focus on capturing the ecological processes that are necessary to support the continued existence of a particular element of natural heritage significance. Conservation areas may include a single occurrence of a rare element or a suite of rare elements or significant features.

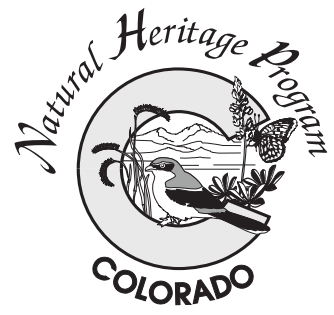


The goal of the process is to identify a land area that can provide the habitat and ecological processes upon which a particular element or suite of elements depends for their continued existence. The best available knowledge of each species' life history is used in conjunction with information about topographic, geomorphic, and hydrologic features, vegetative cover, as well as current and potential land uses. The proposed boundary does not automatically exclude all activity. It is hypothesized that some activities will cause degradation to the element or the process on which they depend, while others will not. Consideration of specific activities or land use changes proposed within or adjacent to the preliminary conservation planning boundary should be carefully considered and evaluated for their consequences to the element on which the conservation unit is based.

The Colorado Division of Wildlife has legal authority over wildlife in the state. CDOW would therefore be responsible for the evaluation of and final decisions regarding any potential effects a proposed project may have on wildlife. If you would like more specific information regarding these or other vertebrate species in the vicinity of the area of interest, please contact the Colorado Division of Wildlife.

The information contained herein represents the results of a search of Colorado Natural Heritage Program's (CNHP) Biodiversity Tracking and Conservation System (BIOTICS), and can be used as notice to anticipate possible impacts or identify areas of interest. Care should be taken in interpreting these data. Sensitive elements are currently known from within the proposed project area, and additional, but undocumented, elements may also exist (see enclosed report). Please note that the absence of data for a particular area, species, or habitat does not necessarily mean that these natural heritage resources do not occur on or adjacent to the project site, rather that our files do not currently contain information to document their presence. CNHP information should not replace field studies necessary for more localized planning efforts, especially if impacts to wildlife habitat are possible.

Although every attempt is made to provide the most current and precise information possible, please be aware that some of our sources provide a higher level of accuracy than others, and some interpretation may be required. CNHP's data system is constantly updated and revised. Please contact CNHP for an update or assistance with interpretation of this natural heritage information.

The data contained in the report is the product and property of the Colorado Natural Heritage Program (CNHP), a sponsored program at Colorado State University (CSU). The data contained herein are provided on an as is, as available basis without warranties of any kind, expressed or implied, including (but not limited to) warranties of merchantability, fitness for a particular purpose, and non-infringement. CNHP, CSU and the state of Colorado further expressly disclaim any warranty that the data are error free or current as of the date supplied.

Sincerely,

Michael Menefee

Environmental Review Coordinator

Enc. 
Locations and Status of Rare and/or Imperiled Species and Natural Communities known from or likely to occur within a two-mile radius of NREL's National Wind Technology Center

Report generated: 23 July 2010

Copyright $\odot$ 2010. Colorado State University. Colorado Natural Heritage Program. All Rights Reserved.

\begin{tabular}{|c|c|c|c|c|c|c|c|c|c|c|c|c|c|c|}
\hline EO_ID & major group & scientific name & common name & Prec & last obs & $\begin{array}{l}\text { Town/ } \\
\text { Range }\end{array}$ & Sec & TRS Note & grank & srank & $\begin{array}{l}\text { eo- } \\
\text { rank }\end{array}$ & $E S A$ & fed stat & st stat \\
\hline 7,691 & Birds & Buteo regalis & Ferruginous Hawk & G & $1993-05-17$ & 001S070W & 27 & & G4 & $\begin{array}{l}\text { S3B, S4 } \\
N\end{array}$ & & - & $\begin{array}{l}\text { BLM } \\
\text { USFS }\end{array}$ & SC \\
\hline 5,064 & Birds & Buteo regalis & Ferruginous Hawk & G & $1984-06-01$ & $\begin{array}{l}\text { 001S070W } \\
\text { 001S070W }\end{array}$ & $\begin{array}{l}16 \\
21\end{array}$ & & G4 & $\begin{array}{l}\text { S3B,S4 } \\
\mathrm{N}\end{array}$ & $\mathrm{H}$ & - & $\begin{array}{l}\text { BLM } \\
\text { USFS }\end{array}$ & SC \\
\hline 14,339 & Birds & $\begin{array}{l}\text { Haliaeetus } \\
\text { leucocephalus }\end{array}$ & Bald Eagle & $\mathrm{s}$ & 2006-99-99 & 001S070W & & & G5 & $\begin{array}{l}\mathrm{S} 1 \mathrm{~B}, \mathrm{~S} 3 \\
\mathrm{~N}\end{array}$ & $C D$ & - & USFS & ST \\
\hline 12,811 & Birds & Melanerpes lewis & Lewis's Woodpecker & G & $1987-05-29$ & $\begin{array}{l}001 \mathrm{~S} 070 \mathrm{~W} \\
001 \mathrm{~S} 070 \mathrm{~W} \\
001 \mathrm{~S} 071 \mathrm{~W} \\
001 \mathrm{~S} 071 \mathrm{~W} \\
002 \mathrm{~S} 070 \mathrm{~W} \\
002 \mathrm{~S} 070 \mathrm{~W} \\
002 \mathrm{~S} 070 \mathrm{~W} \\
002 \mathrm{~S} 070 \mathrm{~W} \\
002 \mathrm{~S} 070 \mathrm{~W} \\
002 \mathrm{~S} 070 \mathrm{~W} \\
002 \mathrm{~S} 071 \mathrm{~W} \\
002 \mathrm{~S} 071 \mathrm{~W} \\
002 \mathrm{~S} 071 \mathrm{~W} \\
002 \mathrm{~S} 071 \mathrm{~W} \\
002 \mathrm{~S} 071 \mathrm{~W} \\
002 \mathrm{~S} 071 \mathrm{~W} \\
002 \mathrm{~S} 071 \mathrm{~W} \\
002 \mathrm{~S} 071 \mathrm{~W}\end{array}$ & $\begin{array}{l}31 \\
32 \\
35 \\
36 \\
05 \\
06 \\
07 \\
08 \\
17 \\
18 \\
01 \\
02 \\
10 \\
11 \\
12 \\
13 \\
14 \\
15\end{array}$ & & G4 & S4 & $\mathrm{H}$ & - & USFS & \\
\hline 9,919 & Insects & Atrytone arogos & Arogos Skipper & $\mathrm{s}$ & $1998-07-27$ & 002S070W & & & G3 & S2 & B & - & & \\
\hline 9,766 & Insects & $\begin{array}{l}\text { Callophrys mossii } \\
\text { schryveri }\end{array}$ & Moss's Elfin & M & $1970-05-03$ & 001S070W & 30 & & G4T3 & $\mathrm{S} 2 \mathrm{S3}$ & $\mathrm{H}$ & - & & \\
\hline 926 & Insects & Celastrina humulus & Hops Feeding Azure & $\mathrm{s}$ & $1995-06-26$ & $\begin{array}{l}\text { 002S070W } \\
\text { 002S070W }\end{array}$ & $\begin{array}{l}03 \\
04\end{array}$ & & G2G3 & S2 & C & - & & \\
\hline 9,207 & Insects & Erynnis martialis & Mottled Dusky Wing & s & 2008-07-01 & $\begin{array}{l}\text { 001S070W } \\
0015070 W \\
0015071 W\end{array}$ & $\begin{array}{l}29 \\
30 \\
36\end{array}$ & & G3 & $\mathrm{S} 2 \mathrm{~S} 3$ & B & - & & \\
\hline
\end{tabular}


Locations and Status of Rare and/or Imperiled Species and Natural Communities known from or likely to occur within a two-mile radius of NREL's National Wind Technology Center

Report generated: 23 July 2010

Copyright $@$ 2010. Colorado State University. Colorado Natural Heritage Program. All Rights Reserved.

\begin{tabular}{|c|c|c|c|c|c|c|c|c|c|c|c|c|c|c|}
\hline EO_ID & major group & scientific name & common name & Prec & last obs & $\begin{array}{l}\text { Town/ } \\
\text { Range }\end{array}$ & Sec & TRS Note & grank & srank & $\begin{array}{l}\text { eo- } \\
\text { rank }\end{array}$ & ESA & fed stat & st stat \\
\hline 10,930 & Insects & Hesperia ottoe & Ottoe Skipper & $\mathrm{G}$ & $1973-07-10$ & 001S070W & & & G3G4 & S2 & $\mathrm{H}$ & - & USFS & \\
\hline 3,184 & Insects & Hesperia ottoe & Ottoe Skipper & s & $1998-07-27$ & 002S070W & & & G3G4 & S2 & B & - & USFS & \\
\hline 10,594 & Insects & Hesperia ottoe & Ottoe Skipper & G & $1961-07-07$ & 001S070W & & & G3G4 & S2 & $\mathrm{H}$ & - & USFS & \\
\hline 1,091 & Insects & Polites origenes & Cross-line Skipper & G & $1972-07-04$ & 002S070W & 20 & & G5 & S3 & $\mathrm{H}$ & - & & \\
\hline 5,015 & Insects & Polites origenes & Cross-line Skipper & G & $1975-07-11$ & $002 S 071 \mathrm{~W}$ & 10 & & G5 & S3 & $\mathrm{H}$ & - & & \\
\hline \multirow[t]{2}{*}{4,500} & Insects & Speyeria idalia & Regal Fritillary & S & $1998-07-13$ & 002S070W & & & G3 & $\mathrm{S} 1$ & E & - & USFS & \\
\hline & & & & & & 002S070W & & & & & & & & \\
\hline \multirow[t]{10}{*}{14,279} & Mammals & Cynomys & Black-tailed Prairie & S & 2006-99-99 & 001S070W & 13 & & G4 & S3 & E & - & USFS & SC \\
\hline & & ludovicianus & Dog & & & 001S070W & 14 & & & & & & & \\
\hline & & & & & & 001S070W & 23 & & & & & & & \\
\hline & & & & & & 001S070W & 24 & & & & & & & \\
\hline & & & & & & 001S070W & 25 & & & & & & & \\
\hline & & & & & & 001S070W & 26 & & & & & & & \\
\hline & & & & & & 001S070W & 35 & & & & & & & \\
\hline & & & & & & 001S070W & 36 & & & & & & & \\
\hline & & & & & & 002S070W & 01 & & & & & & & \\
\hline & & & & & & 002S070W & 02 & & & & & & & \\
\hline \multirow[t]{3}{*}{10,872} & Mammals & Zapus hudsonius & Meadow Jumping & s & 1994-09-21 & 001S070W & & & G5T2 & $\mathrm{S} 1$ & B & LT & & ST \\
\hline & & preblei & Mouse Subsp & & & 002s070W & & & & & & & & \\
\hline & & & & & & 002S070W & & & & & & & & \\
\hline \multirow[t]{2}{*}{7,665} & Mammals & Zapus hudsonius & Meadow Jumping & S & $1993-07-27$ & 002S070W & & & G5T2 & $\mathrm{S} 1$ & D & LT & & ST \\
\hline & & preblei & Mouse Subsp & & & 002S070W & & & & & & & & \\
\hline \multirow[t]{2}{*}{7,466} & Mammals & Zapus hudsonius & Meadow Jumping & $\mathrm{s}$ & $1997-10-01$ & 002S070W & & & G5T2 & $\mathrm{S} 1$ & B & LT & & ST \\
\hline & & preblei & Mouse Subsp & & & 002S070W & & & & & & & & \\
\hline \multirow[t]{2}{*}{1,724} & Mammals & Zapus hudsonius & Meadow Jumping & s & $1997-08-12$ & 001S070W & & & G5T2 & $\mathrm{S} 1$ & C & LT & & ST \\
\hline & & preblei & Mouse Subsp & & & 002S070W & & & & & & & & \\
\hline \multirow[t]{3}{*}{6,898} & Mammals & Zapus hudsonius & Meadow Jumping & $\mathrm{S}$ & 1993-08-11 & 002S070W & & & G5T2 & $\mathrm{S} 1$ & $\mathrm{C}$ & LT & & $\mathrm{ST}$ \\
\hline & & preblei & Mouse Subsp & & & 002S070W & & & & & & & & \\
\hline & & & & & & 002S070W & & & & & & & & \\
\hline
\end{tabular}


Locations and Status of Rare and/or Imperiled Species and Natural Communities known from or likely to occur within a two-mile radius of NREL's National Wind Technology Center

Report generated: 23 July 2010

Copyright $@$ 2010. Colorado State University. Colorado Natural Heritage Program. All Rights Reserved.

\begin{tabular}{|c|c|c|c|c|c|c|c|c|c|c|c|c|c|c|}
\hline EO_ID & major group & scientific name & common name & Prec & last obs & $\begin{array}{l}\text { Town/ } \\
\text { Range }\end{array}$ & Sec & TRS Note & grank & srank & $\begin{array}{l}\text { eo- } \\
\text { rank }\end{array}$ & ESA & fed stat & st stat \\
\hline & & & & & & 002S070W & & & & & & & & \\
\hline \multirow[t]{2}{*}{3,406} & Mammals & Zapus hudsonius & Meadow Jumping & $\mathrm{s}$ & 1998-99-99 & 001S070W & & & G5T2 & S1 & D & LT & & ST \\
\hline & & preblei & Mouse Subsp & & & 001S070W & & & & & & & & \\
\hline \multirow[t]{12}{*}{8,353} & Natural & Andropogon gerardii & Xeric Tallgrass Prairie & $\mathrm{s}$ & 1994-09-01 & 002S070W & 03 & & G2? & $\mathrm{s} 2$ & B & - & & \\
\hline & Communities & - Schizachyrium & & & & 002S070W & 04 & & & & & & & \\
\hline & & $\begin{array}{l}\text { scoparium Western } \\
\text { Great Plains }\end{array}$ & & & & 002S070W & 08 & & & & & & & \\
\hline & & Herbaceous & & & & 002S070W & 09 & & & & & & & \\
\hline & & Vegetation & & & & 002S070W & 10 & & & & & & & \\
\hline & & & & & & 002S070W & 15 & & & & & & & \\
\hline & & & & & & 002S070W & 16 & & & & & & & \\
\hline & & & & & & 002S070W & 17 & & & & & & & \\
\hline & & & & & & 002S070W & 18 & & & & & & & \\
\hline & & & & & & 002S070W & 19 & & & & & & & \\
\hline & & & & & & 002S070W & 20 & & & & & & & \\
\hline & & & & & & 002S070W & 21 & & & & & & & \\
\hline \multirow[t]{5}{*}{14,297} & Natural & Andropogon gerardii & Xeric Tallgrass Prairie & $\mathrm{s}$ & $2007-08-28$ & 001S070W & 27 & & G2? & S2 & $A B$ & - & & \\
\hline & Communities & - Schizachyrium & & & & 001S070W & 28 & & & & & & & \\
\hline & & $\begin{array}{l}\text { scoparium Western } \\
\text { Great Plains }\end{array}$ & & & & 001S070W & 33 & & & & & & & \\
\hline & & Herbaceous & & & & 001S070W & 34 & & & & & & & \\
\hline & & Vegetation & & & & & & & & & & & & \\
\hline \multirow[t]{8}{*}{14,272} & Natural & Andropogon gerardii & Xeric Tallgrass Prairie & $\mathrm{s}$ & 2007-07-20 & 001S070W & 21 & & G2 & S1S2 & B & - & & \\
\hline & Communities & - Sporobolus & & & & 001S070W & 22 & & & & & & & \\
\hline & & $\begin{array}{l}\text { heterolepis Western } \\
\text { Foothills Herbaceous }\end{array}$ & & & & 001S070W & 27 & & & & & & & \\
\hline & & Vegetation & & & & 001S070W & 28 & & & & & & & \\
\hline & & & & & & 001S070W & 29 & & & & & & & \\
\hline & & & & & & 001S070W & 31 & & & & & & & \\
\hline & & & & & & 001S070W & 32 & & & & & & & \\
\hline & & & & & & 001S070W & 33 & & & & & & & \\
\hline 1,262 & $\begin{array}{l}\text { Natural } \\
\text { Communities }\end{array}$ & $\begin{array}{l}\text { Andropogon gerardii } \\
\text { - Sporobolus } \\
\text { heterolepis Western } \\
\text { Foothills Herbaceous } \\
\text { Vegetation }\end{array}$ & Xeric Tallgrass Prairie & $\mathrm{s}$ & 1998-09-16 & 002S070W & 07 & & G2 & S1S2 & B & - & & \\
\hline
\end{tabular}


Locations and Status of Rare and/or Imperiled Species and Natural Communities known from or likely to occur within a two-mile radius of NREL's National Wind Technology Center

Report generated: 23 July 2010

Copyright $@$ 2010. Colorado State University. Colorado Natural Heritage Program. All Rights Reserved.

\begin{tabular}{|c|c|c|c|c|c|c|c|c|c|c|c|c|c|c|}
\hline$E O \_I D$ & major group & scientific name & common name & Prec & last obs & $\begin{array}{l}\text { Town/ } \\
\text { Range }\end{array}$ & Sec & TRS Note & grank & srank & $\begin{array}{l}\text { eo- } \\
\text { rank }\end{array}$ & ESA & fed stat & st stat \\
\hline 14,280 & $\begin{array}{l}\text { Natural } \\
\text { Communities }\end{array}$ & $\begin{array}{l}\text { Hesperostipa comata } \\
\text { Colorado Front Range } \\
\text { Herbaceous } \\
\text { Vegetation }\end{array}$ & $\begin{array}{l}\text { Great Plains Mixed } \\
\text { Grass Prairie }\end{array}$ & $\mathrm{s}$ & $2007-07-20$ & $\begin{array}{l}\text { 001S070W } \\
\text { 001S070W } \\
\text { 001S070W }\end{array}$ & $\begin{array}{l}30 \\
31 \\
32\end{array}$ & & $\mathrm{G} 1 \mathrm{G} 2$ & S1S2 & BC & - & & \\
\hline 14,257 & $\begin{array}{l}\text { Natural } \\
\text { Communities }\end{array}$ & $\begin{array}{l}\text { Hesperostipa } \\
\text { neomexicana } \\
\text { Herbaceous } \\
\text { Vegetation }\end{array}$ & $\begin{array}{l}\text { Great Plains Mixed } \\
\text { Grass Prairie }\end{array}$ & $\mathrm{s}$ & 2007-07-02 & $\begin{array}{l}\text { 001S070W } \\
\text { 001S070W }\end{array}$ & $\begin{array}{l}35 \\
36\end{array}$ & & G3 & S3 & B & - & & \\
\hline 14,262 & $\begin{array}{l}\text { Natural } \\
\text { Communities }\end{array}$ & $\begin{array}{l}\text { Pinus ponderosa / } \\
\text { Cercocarpus } \\
\text { montanus / } \\
\text { Andropogon gerardii } \\
\text { Wooded Herbaceous } \\
\text { Vegetation }\end{array}$ & $\begin{array}{l}\text { Foothills Ponderosa } \\
\text { Pine Scrub } \\
\text { Woodlands }\end{array}$ & s & $2007-07-20$ & 001S070W & 31 & & G2 & $\mathrm{S} 2 ?$ & B & - & & \\
\hline 12,596 & $\begin{array}{l}\text { Natural } \\
\text { Communities }\end{array}$ & $\begin{array}{l}\text { Populus angustifolia / } \\
\text { Salix irrorata } \\
\text { Woodland }\end{array}$ & $\begin{array}{l}\text { Foothills Riparian } \\
\text { Woodland }\end{array}$ & s & 2007-09-06 & $\begin{array}{l}\text { 001S070W } \\
\text { 001S070W } \\
\text { 001S070W } \\
\text { 001S070W } \\
\text { 001S070W } \\
\text { 001S070W }\end{array}$ & $\begin{array}{l}23 \\
24 \\
26 \\
27 \\
33 \\
34\end{array}$ & & G2 & S2 & c & - & & \\
\hline 9,884 & $\begin{array}{l}\text { Vascular } \\
\text { Plants }\end{array}$ & Amorpha nana & dwarf wild indigo & $\mathrm{s}$ & $1993-09-14$ & 001S070W & 31 & & G5 & $\mathrm{S} 2 \mathrm{~S} 3$ & & - & & \\
\hline 8,757 & $\begin{array}{l}\text { Vascular } \\
\text { Plants }\end{array}$ & Amorpha nana & dwarf wild indigo & $\mathrm{s}$ & 1998-07-01 & 002S070W & 07 & & G5 & $\mathrm{S} 2 \mathrm{~S} 3$ & C & - & & \\
\hline 1,460 & $\begin{array}{l}\text { Vascular } \\
\text { Plants }\end{array}$ & Amorpha nana & dwarf wild indigo & $\mathrm{s}$ & $2000-08-17$ & 001S070W & 27 & & G5 & $\mathrm{S} 2 \mathrm{~S} 3$ & D & - & & \\
\hline 1,230 & $\begin{array}{l}\text { Vascular } \\
\text { Plants }\end{array}$ & Aristida basiramea & forktip three-awn & $\mathrm{s}$ & 1994-09-01 & $\begin{array}{l}\text { 002S070W } \\
\text { 002S070W } \\
\text { 002S070W } \\
\text { 002S070W }\end{array}$ & $\begin{array}{l}09 \\
10 \\
15 \\
16\end{array}$ & & G5 & S1 & E & - & & \\
\hline 14,223 & $\begin{array}{l}\text { Vascular } \\
\text { Plants }\end{array}$ & Carex oreocharis & a sedge & $\mathrm{s}$ & 1984-06-09 & $\begin{array}{l}\text { 001S070W } \\
\text { 001S070W }\end{array}$ & $\begin{array}{l}29 \\
32\end{array}$ & & G3 & S1 & $\mathrm{H}$ & - & & \\
\hline 14,237 & $\begin{array}{l}\text { Vascular } \\
\text { Plants }\end{array}$ & Carex saximontana & $\begin{array}{l}\text { Rocky Mountain } \\
\text { sedge }\end{array}$ & $\mathrm{s}$ & $2007-07-20$ & 001S070W & 31 & & G5 & S1 & E & - & & \\
\hline
\end{tabular}


Locations and Status of Rare and/or Imperiled Species and Natural Communities known from or likely to occur within a two-mile radius of NREL's National Wind Technology Center

Report generated: 23 July 2010

Copyright $\odot$ 2010. Colorado State University. Colorado Natural Heritage Program. All Rights Reserved.

\begin{tabular}{|c|c|c|c|c|c|c|c|c|c|c|c|c|c|c|}
\hline EO_ID & major group & scientific name & common name & Prec & last obs & $\begin{array}{l}\text { Town/ } \\
\text { Range }\end{array}$ & $\mathrm{Sec}$ & TRS Note & grank & srank & $\begin{array}{l}\text { eo- } \\
\text { rank }\end{array}$ & $E S A$ & fed stat & st stat \\
\hline \multirow[t]{2}{*}{14,220} & \multirow{2}{*}{$\begin{array}{l}\text { Vascular } \\
\text { Plants }\end{array}$} & \multirow{2}{*}{$\begin{array}{l}\text { Crataegus } \\
\text { chrysocarpa }\end{array}$} & \multirow[t]{2}{*}{ yellow hawthorn } & \multirow[t]{2}{*}{ M } & \multirow[t]{2}{*}{ 1986-09-05 } & 001S070W & 28 & & \multirow[t]{2}{*}{ G5 } & \multirow[t]{2}{*}{ S1 } & \multirow[t]{2}{*}{$\mathrm{H}$} & \multirow[t]{2}{*}{-} & & \\
\hline & & & & & & 001S070W & 33 & & & & & & & \\
\hline 13,584 & $\begin{array}{l}\text { Vascular } \\
\text { Plants }\end{array}$ & $\begin{array}{l}\text { Crocanthemum } \\
\text { bicknellii }\end{array}$ & frostweed & $\mathrm{S}$ & $1997-08-28$ & 001S070W & 31 & & G5 & $\mathrm{S} 2$ & E & - & & \\
\hline 7,042 & $\begin{array}{l}\text { Vascular } \\
\text { Plants }\end{array}$ & Liatris ligulistylis & gay-feather & G & $9999-08-11$ & 001S071W & \multicolumn{2}{|l|}{12} & G5? & S1S2 & $\mathrm{H}$ & - & & \\
\hline 13,554 & $\begin{array}{l}\text { Vascular } \\
\text { Plants }\end{array}$ & Nuttallia sinuata & wavy-leaf stickleaf & $\mathrm{S}$ & 1993-07-09 & 001S070W & 31 & & G3 & S2 & $\mathrm{E}$ & - & & \\
\hline 7,102 & $\begin{array}{l}\text { Vascular } \\
\text { Plants }\end{array}$ & Spiranthes diluvialis & Ute ladies' tresses & $\mathrm{S}$ & 2006-99-99 & 001S070W & & & G2G3 & $\mathrm{S} 2$ & $\mathrm{D}$ & LT & & \\
\hline 3,213 & $\begin{array}{l}\text { Vascular } \\
\text { Plants }\end{array}$ & Viola pedatifida & prairie violet & M & $1948-04-29$ & 001S070W & 21 & & G5 & S2 & $\mathrm{H}$ & - & & \\
\hline 3,964 & Vascular & Viola pedatifida & prairie violet & $\mathrm{S}$ & $1993-05-27$ & 001S070W & 31 & & G5 & S2 & B & - & & \\
\hline & Plants & & & & & 002S070W & 06 & & & & & & & \\
\hline
\end{tabular}




\section{APPENDIX B}

Plant Community Species List Tables 


\section{Legend to classification codes:}

\section{Origin:}

Refers to origin of species

$\mathrm{N} \quad$ Native to the Front Range area

I Introduced or exotic species

\section{Species:}

Refers to blooming/production season for grass species

C cold season (spring/early summer)

W warm season (mid to late summer)

\section{Life Form:}

Refers to life form/strategy of species

AF annual forb

BF biennial forb

PF perennial forb

AG annual grass/graminoid (includes rushes and sedges)

PG perennial grass/graminoid (includes rushes and sedges)

SU succulent

SS subshrub

S shrub

$\mathrm{T}$ tree

V vine 
Table 1. Xeric Mixed Grassland

\begin{tabular}{|c|c|c|c|c|c|c|}
\hline \multicolumn{7}{|c|}{$\begin{array}{c}\text { Plant Species List } \\
\text { NREL National Wind Technology Center }\end{array}$} \\
\hline Scientific Binomial & Synonomy & Common Name & Family & Origin & Season & $\begin{array}{l}\text { Life } \\
\text { Form }\end{array}$ \\
\hline Asclepias pumila & & Plains milkweed & Aclepiadaceae - Milkweed Family & $\mathrm{N}$ & NA & PF \\
\hline Yucca glauca & & Yucca & Agavaceae - Agave Family & $\mathrm{N}$ & NA & SU \\
\hline Allium textile & & Wild onion & Alliaceae - Onion Family & $\mathrm{N}$ & NA & PF \\
\hline Eremogone fendleri & & Desert sandwort & Alsinaceae - Chickweed Family & $\mathrm{N}$ & NA & $\mathrm{PF}$ \\
\hline Paronychia jamesii & & James' nailwort & Alsinaceae - Chickweed Family & $\mathrm{N}$ & NA & PF \\
\hline Amaranthus retroflexus & & Redroot pigweed & Amaranthaceae - Amaranth Family & 1 & NA & $\mathrm{AF}$ \\
\hline $\begin{array}{l}\text { Rhus aromatica var. } \\
\text { trilobata }\end{array}$ & & Skunkbrush & Anacardiaceae - Sumac Family & $\mathrm{N}$ & NA & $\mathrm{S}$ \\
\hline Harbouria trachypleura & & Whisk broom parsley & Apiaceae - Parsley Family & $\mathrm{N}$ & NA & PF \\
\hline Lomatium orientale & & Lomatium & Apiaceae - Parsley Family & $\mathrm{N}$ & NA & PF \\
\hline Apocynum cannabinum & & Indian hemp & Apocynaceae - Dogbane Family & $\mathrm{N}$ & NA & $\mathrm{PF}$ \\
\hline Asclepias speciosa & & Showy milkweed & Asclepiadaceae - Milkweed Family & $\mathrm{N}$ & NA & $\mathrm{PF}$ \\
\hline Achillea lanulosa & & Yarrow & Asteraceae - Sunflower Family & $\mathrm{N}$ & NA & $\mathrm{PF}$ \\
\hline Acosta diffusa & Centaurea diffusa & Diffuse knapweed & Asteraceae - Sunflower Family & 1 & NA & $\mathrm{BF} / \mathrm{PF}$ \\
\hline Ambrosia psilostachya & & Western ragweed & Asteraceae - Sunflower Family & $\mathrm{N}$ & NA & PF \\
\hline Anaphalis margaritacea & & Pearly everlasting & Asteraceae - Sunflower Family & $\mathrm{N}$ & NA & $\mathrm{PF}$ \\
\hline Antennaria rosea & & Pussytoes & Asteraceae - Sunflower Family & $\mathrm{N}$ & NA & PF \\
\hline Arnica fulgens & & Arnica & Asteraceae - Sunflower Family & $\mathrm{N}$ & NA & $\mathrm{PF}$ \\
\hline Artemisia campestris & & Field sagewort & Asteraceae - Sunflower Family & $\mathrm{N}$ & NA & $\mathrm{PF}$ \\
\hline Artemisia frigida & & Fringed sagebrush & Asteraceae - Sunflower Family & $\mathrm{N}$ & NA & SS \\
\hline Artemisia ludoviciana & & Prairie sagewort & Asteraceae - Sunflower Family & $\mathrm{N}$ & NA & PF \\
\hline Aster ericoides & & White aster & Asteraceae - Sunflower Family & $\mathrm{N}$ & NA & PF \\
\hline Aster porteri & & White aster & Asteraceae - Sunflower Family & $\mathrm{N}$ & NA & PF \\
\hline Breea arvensis & Circium arvense & Canada thistle & Asteraceae - Sunflower Family & $\mathrm{I}$ & NA & PF \\
\hline Brickellia eupatorioides & & Brickellia & Asteraceae - Sunflower Family & $\mathrm{N}$ & NA & PF \\
\hline Carduus nutans & & Musk thistle & Asteraceae - Sunflower Family & $\mathrm{I}$ & NA & $\mathrm{BF}$ \\
\hline $\begin{array}{l}\text { Chrysothamnus } \\
\text { nauseosus }\end{array}$ & & Rubber rabbitbrush & Asteraceae - Sunflower Family & $\mathrm{N}$ & NA & $\mathrm{s}$ \\
\hline Cichorium intybus & & Chicory & Asteraceae - Sunflower Family & 1 & NA & PF \\
\hline Cirsium undulatum & & Wavyleaf thistle & Asteraceae - Sunflower Family & $\mathrm{N}$ & NA & $\mathrm{BF}$ \\
\hline Cirsium vulgare & & Bull thistle & Asteraceae - Sunflower Family & $\mathrm{I}$ & NA & $\mathrm{BF}$ \\
\hline Conyza canadensis & & Horseweed & Asteraceae - Sunflower Family & $\mathrm{N}$ & NA & $\mathrm{AF}$ \\
\hline Erigeron divergens & & Spreading fleabane & Asteraceae - Sunflower Family & $\mathrm{N}$ & NA & $\mathrm{BF}$ \\
\hline Gaillardia aristata & & Blanketflower & Asteraceae - Sunflower Family & $\mathrm{N}$ & NA & $\mathrm{PF}$ \\
\hline Grindelia squarrosa & & Curlycup gumweed & Asteraceae - Sunflower Family & $\mathrm{N}$ & NA & $\mathrm{BF}$ \\
\hline Gutierrezia sarothrae & & Broom snakeweed & Asteraceae - Sunflower Family & $\mathrm{N}$ & NA & SS \\
\hline Helianthus annuus & & Common sunflower & Asteraceae - Sunflower Family & $\mathrm{N}$ & NA & $\mathrm{AF}$ \\
\hline Helianthus petiolaris & & Prairie sunflower & Asteraceae - Sunflower Family & $\mathrm{N}$ & NA & $\mathrm{AF}$ \\
\hline Helianthus rigidus & & Stiff sunflower & Asteraceae - Sunflower Family & $\mathrm{N}$ & NA & $\mathrm{PF}$ \\
\hline Lactuca serriola & & Prickly lettuce & Asteraceae - Sunflower Family & $\mathrm{I}$ & NA & $\mathrm{BF}$ \\
\hline Liatris punctata & & Dotted gayfeather & Asteraceae - Sunflower Family & $\mathrm{N}$ & NA & PF \\
\hline Oligosporus dracunculus & Artemisia dracunculus & Wild tarragon & Asteraceae - Sunflower Family & $\mathrm{N}$ & NA & PF \\
\hline
\end{tabular}


Table 1. Xeric Mixed Grassland

\begin{tabular}{|c|c|c|c|c|c|c|}
\hline \multicolumn{7}{|c|}{$\begin{array}{c}\text { Plant Species List } \\
\text { NREL National Wind Technology Center }\end{array}$} \\
\hline Scientific Binomial & Synonomy & Common Name & Family & Origin & Season & $\begin{array}{l}\text { Life } \\
\text { Form }\end{array}$ \\
\hline Ratibida columnifera & & Prairie coneflower & Asteraceae - Sunflower Family & $\mathrm{N}$ & NA & PF \\
\hline Senecio crassulus & & Butterweed & Asteraceae - Sunflower Family & $\mathrm{N}$ & NA & PF \\
\hline Senecio integerrimus & & Groundsel & Asteraceae - Sunflower Family & $\mathrm{N}$ & NA & $\mathrm{BF} / \mathrm{PF}$ \\
\hline Senecio spartioides & & Groundsel & Asteraceae - Sunflower Family & $\mathrm{N}$ & NA & PF/SS \\
\hline Solidago missouriensis & & Prairie goldenrod & Asteraceae - Sunflower Family & $\mathrm{N}$ & NA & PF \\
\hline Solidago mollis & & Soft goldenrod & Asteraceae - Sunflower Family & $\mathrm{N}$ & NA & $\mathrm{PF}$ \\
\hline Solidago nana & & Goldenrod & Asteraceae - Sunflower Family & $\mathrm{N}$ & NA & PF \\
\hline Taraxacum officinale & & Common dandelion & Asteraceae - Sunflower Family & $\mathrm{I}$ & NA & $\mathrm{PF}$ \\
\hline Townsendia hookeri & & Easter daisy & Asteraceae - Sunflower Family & $\mathrm{N}$ & NA & PF \\
\hline Tragopogon dubius & & Goatsbeard & Asteraceae - Sunflower Family & $\mathrm{I}$ & NA & $\mathrm{BF}$ \\
\hline Cynoglossum officinale & & Houndstongue & Boraginaceae - Borage Family & 1 & NA & $\mathrm{BF}$ \\
\hline Lithospermum incisum & & Narrowleaf gromwell & Boraginaceae - Borage Family & $\mathrm{N}$ & NA & PF \\
\hline Oreocarya virgata & Cryptantha virgata & Miner's candle & Boraginaceae - Borage Family & $\mathrm{N}$ & NA & PF \\
\hline Alyssum alyssoides & & Pale alyssum & Brassicaceae - Mustard Family & $\mathrm{I}$ & NA & $\mathrm{AF}$ \\
\hline Cardaria draba & & Whitetop & Brassicaceae - Mustard Family & $\mathrm{I}$ & NA & $\mathrm{PF}$ \\
\hline Erysimum capitatum & & Western wallflower & Brassicaceae - Mustard Family & $\mathrm{N}$ & NA & $\mathrm{BF}$ \\
\hline Lesquerella ludoviciana & & Bladderpod & Brassicaceae - Mustard Family & $\mathrm{N}$ & NA & $\mathrm{PF}$ \\
\hline Sisymbrium altissimum & & Tumbling mustard & Brassicaceae - Mustard Family & $\mathrm{I}$ & NA & $\mathrm{AF}$ \\
\hline $\begin{array}{l}\text { Coryphantha } \\
\text { missouriensis }\end{array}$ & & Yellow pincushion & Cactaceae - Cactus Family & $\mathrm{N}$ & NA & SU \\
\hline Echinocereus viridiflorus & & Hen-and-chicks & Cactaceae - Cactus Family & $\mathrm{N}$ & NA & SU \\
\hline Opuntia fragilis & & Brittle cactus & Cactaceae - Cactus Family & $\mathrm{N}$ & NA & SU \\
\hline Opuntia macrorhiza & & Plains prickly pear & Cactaceae - Cactus Family & $\mathrm{N}$ & NA & SU \\
\hline Calochortus gunnisonii & & Mariposa lily & Calochortaceae - Mariposa Family & $\mathrm{N}$ & NA & $\mathrm{PF}$ \\
\hline $\begin{array}{l}\text { Symphoricarpos } \\
\text { occidentalis }\end{array}$ & & Western snowberry & Caprifoliaceae - Honeysuckle Family & $\mathrm{N}$ & NA & S \\
\hline Bassia sieversiana & Kochia scoparia & Kochia & Chenopodiaceae - Goosefoot Family & 1 & NA & $\mathrm{AF}$ \\
\hline Chenopodium album & & Common lambsquarters & Chenopodiaceae - Goosefoot Family & $\mathrm{I}$ & NA & $\mathrm{AF}$ \\
\hline Kochia scoparia & Bassia sieversiana & Summer cypress & Chenopodiaceae - Goosefoot Family & 1 & NA & $\mathrm{AF}$ \\
\hline Convolvulus arvensis & & Field bindweed & Convolvulaceae - Morning Glory Family & 1 & NA & PF \\
\hline Carex brevior & & Sedge & Cyperaceae - Sedge Family & $\mathrm{N}$ & NA & $P G$ \\
\hline Carex filifolia & & Thread-leafed sedge & Cyperaceae - Sedge Family & $\mathrm{N}$ & NA & PG \\
\hline Tithymalus brachyceras & & Spurge & Euphorbiaceae - Spurge Family & $\mathrm{N}$ & NA & PF \\
\hline Ephorbia esula & & Leafy spurge & Euphobiaceae - Spurge Family & 1 & NA & PF \\
\hline Tithymalus montanus & & Spurge & Euphorbiaceae - Spurge Family & $\mathrm{N}$ & NA & PF \\
\hline Astragalus crassicarpus & & Groundplum milkvetch & Fabaceae - Pea Family & $\mathrm{N}$ & NA & $\mathrm{PF}$ \\
\hline Astragalus mollissimus & & Wooly locoweed & Fabaceae - Pea Family & $\mathrm{N}$ & NA & $\mathrm{PF}$ \\
\hline Astragalus sp. & & Locoweed & Fabaceae - Pea Family & $\mathrm{N}$ & NA & $\mathrm{PF}$ \\
\hline Dalea purpurea & $\begin{array}{l}\text { Petalostemon } \\
\text { purpurea }\end{array}$ & Purple prairie clover & Fabaceae - Pea Family & $\mathrm{N}$ & NA & PF \\
\hline Glycyrrhiza lepidota & & American licorice & Fabaceae - Pea Family & $\mathrm{N}$ & NA & $\mathrm{PF}$ \\
\hline Lupinus argenteus & & Silver lupine & Fabaceae - Pea Family & $\mathrm{N}$ & NA & PF \\
\hline
\end{tabular}


Table 1. Xeric Mixed Grassland

\begin{tabular}{|c|c|c|c|c|c|c|}
\hline \multicolumn{7}{|c|}{$\begin{array}{c}\text { Plant Species List } \\
\text { NREL National Wind Technology Center }\end{array}$} \\
\hline Scientific Binomial & Synonomy & Common Name & Family & Origin & Season & $\begin{array}{l}\text { Life } \\
\text { Form }\end{array}$ \\
\hline Melilotus albus & & White sweetclover & Fabaceae - Pea Family & 1 & NA & $\mathrm{BF}$ \\
\hline Melilotus officinalis & & Yellow sweetclover & Fabaceae - Pea Family & 1 & NA & $\mathrm{BF}$ \\
\hline Oxytropis lambertii & & Lambert locoweed & Fabaceae - Pea Family & $\mathrm{N}$ & NA & PF \\
\hline Psoralidium tenuiflora & & Slimflower scurfpea & Fabaceae - Pea Family & $\mathrm{N}$ & NA & PF \\
\hline Thermopsis rhombifolia & & Prairie goldenpea & Fabaceae - Pea Family & $\mathrm{N}$ & NA & PF \\
\hline Pneumonanthe affinis & Gentiana affinis & Bottle gentian & Gentianaceae - Gentian Family & $\mathrm{N}$ & NA & PF \\
\hline Erodium cicutarium & & Filaree & Geraniaceae - Geranium Family & $\mathrm{I}$ & NA & $\mathrm{AF}$ \\
\hline Delphinium nuttallianum & & Blue larkspur & Helleboraceae - Hellebore Family & $\mathrm{N}$ & NA & $\mathrm{PF}$ \\
\hline Phacelia heterophylla & $\begin{array}{l}\text { Phacelia hastata var. } \\
\text { leucophylla }\end{array}$ & Scorpioweed & Hydrophyllaceae - Waterleaf Family & $\mathrm{N}$ & NA & PF \\
\hline Hypericum perforatum & & St. Johnswort & Hypericaceae - St. Johnswort family & $\mathrm{I}$ & NA & $\mathrm{PF}$ \\
\hline Iris missouriensis & & Wild iris & Iridaceae - Iris Family & $\mathrm{N}$ & NA & PF \\
\hline Juncus sp. & & Rush & Juncaceae - Rush Family & $\mathrm{N}$ & NA & PG \\
\hline Leucocrinum montanum & & Sand lily & Liliaceae - Lily Family & $\mathrm{N}$ & NA & PF \\
\hline Linum lewisii & & Perennial flax & Linaceaea - Flax Family & $\mathrm{N}$ & NA & $\mathrm{PF}$ \\
\hline Sphaeralcea coccinea & & Scarlet globemallow & Malvaceae - Mallow Family & $\mathrm{N}$ & NA & PF \\
\hline $\begin{array}{l}\text { Toxicoscordion } \\
\text { venenosum }\end{array}$ & Zigadenus venenosus & Death camass & Melanthiaceae - False Hellbore Family & $\mathrm{N}$ & NA & PF \\
\hline Calylophus serrulatus & & Shrubby evening-primrose & Onagraceae - Evening-primrose Family & $\mathrm{N}$ & NA & SS \\
\hline Gaura coccinea & & Scarlet gaura & Onagraceae - Evening-primrose Family & $\mathrm{N}$ & NA & PF \\
\hline Oenothera howardii & $\begin{array}{l}\text { Oenothera } \\
\text { brachycarpa }\end{array}$ & Evening-primrose & Onagraceae - Evening-primrose Family & $\mathrm{N}$ & NA & PF \\
\hline Oenothera villosa & & Common evening-primrose & Onagraceae - Evening-primrose Family & $\mathrm{N}$ & NA & $\mathrm{PF}$ \\
\hline Aphyllon fasciculatum & $\begin{array}{l}\text { Orobanche } \\
\text { fasciculata }\end{array}$ & Broomrape & Orobanchaceae - Broomrape Family & $\mathrm{N}$ & NA & PF \\
\hline Oxalis dillenii & & Woodsorrel & Oxalidaceae - Woodsorrel Family & $\mathrm{N}$ & NA & PF \\
\hline Argemone polyanthemos & & Prickly poppy & Papaveracae - Poppy Family & $\mathrm{N}$ & NA & $\mathrm{PF}$ \\
\hline Pinus ponderosa & & Ponderosa pine & Pinaceae - Pine Family & $\mathrm{N}$ & NA & $\mathrm{T}$ \\
\hline Plantago lanceolata & & English plantain & Plantaginaceae - Plantain Family & 1 & NA & $\mathrm{PF}$ \\
\hline Agropyron cristatum & & Crested wheatgrass & Poaceae - Grass Family & $\mathrm{I}$ & $\mathrm{C}$ & PG \\
\hline Agrostis scabra & & Ticklegrass & Poaceae - Grass Family & $\mathrm{N}$ & $\mathrm{C}$ & $P G$ \\
\hline Andropogon gerardii & & Big bluestem & Poaceae - Grass Family & $\mathrm{N}$ & W & $P G$ \\
\hline Anisantha tectorum & Bromus tectorum & Cheatgrass & Poaceae - Grass Family & 1 & $\mathrm{C}$ & $A G$ \\
\hline Aristida purpurea & $\begin{array}{l}\text { Aristida purpurea var. } \\
\text { robusta }\end{array}$ & Red three-awn & Poaceae - Grass Family & $\mathrm{N}$ & W & PG \\
\hline Bouteloua curtipendula & & Side-oats grama & Poaceae - Grass Family & $\mathrm{N}$ & W & PG \\
\hline Bromopis inermis & Bromus inermis & Smooth bromegrass & Poaceae - Grass Family & $\mathrm{I}$ & $\mathrm{C}$ & PG \\
\hline Buchloë dactyloides & & Buffalograss & Poaceae - Grass Family & $\mathrm{N}$ & W & $P G$ \\
\hline Chondrosum gracile & Bouteloua gracilis & Blue grama & Poaceae - Grass Family & $\mathrm{N}$ & W & $P G$ \\
\hline Dactylis glomerata & & Orchard grass & Poaceae - Grass Family & $\mathrm{I}$ & $\mathrm{C}$ & PG \\
\hline Elymus canadensis & & Canada wild rye & Poaceae - Grass Family & $\mathrm{N}$ & $\mathrm{C}$ & $P G$ \\
\hline Elymus trachycaulus & $\begin{array}{l}\text { Agropyron caninum } \\
\text { ssp. majus }\end{array}$ & Slender wheatgrass & Poaceae - Grass Family & $\mathrm{N}$ & $\mathrm{C}$ & PG \\
\hline
\end{tabular}


Table 1. Xeric Mixed Grassland

\begin{tabular}{|c|c|c|c|c|c|c|}
\hline \multicolumn{7}{|c|}{$\begin{array}{c}\text { Plant Species List } \\
\text { NREL National Wind Technology Center }\end{array}$} \\
\hline Scientific Binomial & Synonomy & Common Name & Family & Origin & Season & $\begin{array}{c}\text { Life } \\
\text { Form }\end{array}$ \\
\hline Koeleria macrantha & Koeleria pyramidata & Junegrass & Poaceae - Grass Family & $\mathrm{N}$ & C & PG \\
\hline Lophopyrum elongatum & Agropyron elongatum & Tall wheatgrass & Poaceae - Grass Family & I & $\mathrm{C}$ & PG \\
\hline Muhlenbergia montana & & Mountain muhly & Poaceae - Grass Family & $\mathrm{N}$ & W & PG \\
\hline Oryzopsis hymenoides & & Indian ricegrass & Poaceae - Grass Family & $\mathrm{N}$ & $\mathrm{C}$ & PG \\
\hline Panicum capillare & & Witchgrass & Poaceae - Grass Family & $\mathrm{N}$ & W & AG \\
\hline Panicum virgatum & & Switchgrass & Poaceae - Grass Family & $\mathrm{N}$ & W & $P G$ \\
\hline Pascopyrum smithii & Agropyron smithii & Western wheatgrass & Poaceae - Grass Family & $\mathrm{N}$ & $\mathrm{C}$ & $P G$ \\
\hline Pleum pratense & & Common timothy & Poaceae - Grass Family & I & $\mathrm{C}$ & PG \\
\hline Poa compressa & & Canada bluegrass & Poaceae - Grass Family & $\mathrm{I}$ & $\mathrm{C}$ & PG \\
\hline Poa pratensis & & Kentucky bluegrass & Poaceae - Grass Family & I & $\mathrm{C}$ & PG \\
\hline Poa secunda & Poa canbyi & Canby bluegrass & Poaceae - Grass Family & $\mathrm{N}$ & $\mathrm{C}$ & PG \\
\hline $\begin{array}{l}\text { Schizachyrium } \\
\text { scoparium }\end{array}$ & $\begin{array}{l}\text { Andropogon } \\
\text { scoparius }\end{array}$ & Little bluestem & Poaceae - Grass Family & $\mathrm{N}$ & W & $P G$ \\
\hline Sorghastrum nutans & & Indian-grass & Poaceae - Grass Family & $\mathrm{N}$ & W & PG \\
\hline Sporobolus cryptandrus & & Sand dropseed & Poaceae - Grass Family & $\mathrm{N}$ & $\mathrm{W}$ & PG \\
\hline Stipa comata & & Needle-and-thread & Poaceae - Grass Family & $\mathrm{N}$ & $\mathrm{C}$ & PG \\
\hline Stipa viridula & & Green needlegrass & Poaceae - Grass Family & $\mathrm{N}$ & C & PG \\
\hline Ipomopsis spicata & & Ipomopsis & Polemoniaceae - Phlox Family & $\mathrm{N}$ & NA & PF \\
\hline Eriogonum alatum & & Winged eriogonum & Polygonaceae - Buckwheat Family & $\mathrm{N}$ & NA & PF \\
\hline Eriogonum sp. & & Wild buckwheat & Polygonaceae - Buckwheat Family & $\mathrm{N}$ & NA & PF \\
\hline Eriogonum umbellatum & & Wild buckwheat & Polygonaceae - Buckwheat Family & $\mathrm{N}$ & NA & PF \\
\hline Pterogonum alatum & Erigeron alatum & Winged buckwheat & Polygonaceae - Buckwheat Family & $\mathrm{N}$ & NA & PF \\
\hline Rumex crispus & & Curly dock & Polygonaceae - Buckwheat Family & $\mathrm{N}$ & NA & PF \\
\hline Talinum parviflorum & & Prairie fameflower & Portulacaceae - Purslane Family & $\mathrm{N}$ & NA & PF \\
\hline Crataegus erythropoda & & Hawthorn & Rosaceae - Rose Family & $\mathrm{N}$ & NA & $\mathrm{T}$ \\
\hline Potentilla hippiana & & Wooly cinquefoil & Rosaceae - Rose Family & $\mathrm{N}$ & NA & PF \\
\hline Potentilla recta & & Sulfur cinquefoil & Rosaceae - Rose Family & $\mathrm{I}$ & NA & PF \\
\hline Rosa sayi & Rosa acicularis & Prickly wild rose & Rosaceae - Rose Family & $\mathrm{N}$ & NA & $\mathrm{S}$ \\
\hline Rosa woodsii & & Woods rose & Rosaceae - Rose Family & $\mathrm{N}$ & NA & $\mathrm{S}$ \\
\hline Commandra umbellata & & Bastard-toadflax & Santalaceae - Sandelwood Family & $\mathrm{N}$ & NA & PF \\
\hline Castilleja sessiliflora & & Downy paintbrush & Scrophulariaceae - Figwort Family & $\mathrm{N}$ & NA & PF \\
\hline $\begin{array}{l}\text { Linaria genistifolia } \\
\text { subsp. dalmatica }\end{array}$ & Linaria dalmatica & Dalmatian toadflax & Scrophulariaceae - Figwort Family & I & NA & PF \\
\hline Penstemon virgatus & & Penstemon & Scrophulariaceae - Figwort Family & $\mathrm{N}$ & NA & $\mathrm{PF}$ \\
\hline Verbascum blattaria & & Moth mullein & Scrophulariaceae - Figwort Family & I & NA & BF \\
\hline Verbascum thapsus & & Common mullein & Scrophulariaceae - Figwort Family & 1 & NA & $\mathrm{BF}$ \\
\hline Verbena bracteata & & Prostrate verbena & Verbebaceae - Verbena Family & $\mathrm{N}$ & NA & PF \\
\hline Viola nuttallii & & Yellow prairie violet & Violaceae - Violet Family & $\mathrm{N}$ & NA & PF \\
\hline
\end{tabular}


Table 2. Mesic Mixed Grassland

\begin{tabular}{|c|c|c|c|c|c|c|}
\hline \multicolumn{7}{|c|}{$\begin{array}{c}\text { Plant Species List } \\
\text { NREL National Wind Technology Center }\end{array}$} \\
\hline Scientific Binomial & Synonomy & Common Name & Family & Origin & Season & $\begin{array}{l}\text { Life } \\
\text { Form }\end{array}$ \\
\hline Allium textile & & Wild onion & Alliaceae - Onion Family & $\mathrm{N}$ & NA & PF \\
\hline Acosta diffusa & Centaurea diffusa & Diffuse knapweed & Asteraceae - Sunflower Family & $\mathrm{I}$ & NA & BF/PF \\
\hline Ambrosia psilostachya & & Western ragweed & Asteraceae - Sunflower Family & $\mathrm{N}$ & NA & $\mathrm{PF}$ \\
\hline Artemisia ludoviciana & & Prairie sagewort & Asteraceae - Sunflower Family & $\mathrm{N}$ & NA & PF \\
\hline Aster porteri & & White aster & Asteraceae - Sunflower Family & $\mathrm{N}$ & NA & PF \\
\hline Breea arvensis & Cirsium arvense & Canada thistle & Asteraceae - Sunflower Family & I & NA & PF \\
\hline Carduus nutans & & Musk thistle & Asteraceae - Sunflower Family & I & NA & $\mathrm{BF}$ \\
\hline Cirsium undulatum & & Wavyleaf thistle & Asteraceae - Sunflower Family & $\mathrm{N}$ & NA & BF \\
\hline Gaillardia aristata & & Blanketflower & Asteraceae - Sunflower Family & $\mathrm{N}$ & NA & PF \\
\hline Lactuca serriola & & Prickly lettuce & Asteraceae - Sunflower Family & $\mathrm{I}$ & NA & $\mathrm{BF}$ \\
\hline Liatris punctata & & Dotted gayfeather & Asteraceae - Sunflower Family & $\mathrm{N}$ & NA & $\mathrm{PF}$ \\
\hline Ratibida columnifera & & Prairie coneflower & Asteraceae - Sunflower Family & $\mathrm{N}$ & NA & $\mathrm{PF}$ \\
\hline Tragopogon dubius & & Salsify & Asteraceae - Sunflower Family & $\mathrm{I}$ & NA & $\mathrm{BF}$ \\
\hline Lithospermum arvense & & Corn gromwell & Boraginaceae - Borage Family & I & NA & $\mathrm{AF}$ \\
\hline Lesquerella ludoviciana & & Bladderpod & Brassicaceae - Mustard Family & $\mathrm{N}$ & NA & PF \\
\hline Thlaspi arvense & & Fanweed & Brassicaceae - Mustard Family & $\mathrm{I}$ & NA & $\mathrm{AF}$ \\
\hline Convolvulus arvensis & & Field bindweed & $\begin{array}{l}\text { Convolvulaceae - Morning Glory } \\
\text { Family }\end{array}$ & I & NA & $P F$ \\
\hline Eleocharis palustris & & Spike-rush & Cyperaceae - Sedge Family & $\mathrm{N}$ & NA & PG \\
\hline Melilotus officinalis & & Yellow sweetclover & Fabaceae - Pea Family & $\mathrm{I}$ & NA & $\mathrm{BF}$ \\
\hline Psoralidium tenuiflora & & Slimflower scurfpea & Fabaceae - Pea Family & $\mathrm{N}$ & NA & PF \\
\hline Pneumonanthe affinis & Gentiana affinis & Bottle gentian & Gentianaceae - Gentian Family & $\mathrm{N}$ & NA & $\mathrm{PF}$ \\
\hline Phaceelia heterophylla & $\begin{array}{l}\text { Phacelia hastata var. } \\
\text { leucophylla }\end{array}$ & Scorpionweed & Hydrophyllaceae - Waterleaf Famiy & $\mathrm{N}$ & NA & PF \\
\hline Hypericum perforatum & & St. Johnswort & Hypericaceae - St. Johnswort Family & I & NA & PF \\
\hline Agrostis gigantea & Agrostis alba & Redtop & Poaceae - Grass Family & 1 & $\mathrm{C}$ & $P G$ \\
\hline Andropogon gerardii & & Big bluestem & Poaceae - Grass Family & $\mathrm{N}$ & $\mathrm{W}$ & PG \\
\hline Bouteloua curtipendula & & Side-oats grama & Poaceae - Grass Family & $\mathrm{N}$ & W & PG \\
\hline Bromopis inermis & Bromus inermis & Smooth bromegrass & Poaceae - Grass Family & $\mathrm{I}$ & $\mathrm{C}$ & PG \\
\hline Koeleria macrantha & Koeleria pyramidata & Junegrass & Poaceae - Grass Family & $\mathrm{N}$ & $\mathrm{C}$ & $P G$ \\
\hline Muhlenbergia montana & & Mountain muhly & Poaceae - Grass Family & $\mathrm{N}$ & W & PG \\
\hline Panicum virgatum & & Switchgrass & Poaceae - Grass Family & $\mathrm{N}$ & W & $P G$ \\
\hline Pascopyrum smithii & Agropyron smithii & Western wheatgrass & Poaceae - Grass Family & $\mathrm{N}$ & $\mathrm{C}$ & PG \\
\hline Poa compressa & & Canada bluegrass & Poaceae - Grass Family & $\mathrm{I}$ & $\mathrm{C}$ & PG \\
\hline Poa fendleriana & & Muttongrass & Poaceae - Grass Family & $\mathrm{N}$ & $\mathrm{C}$ & PG \\
\hline Poa pratensis & & Kentucky bluegrass & Poaceae - Grass Family & I & $\mathrm{C}$ & PG \\
\hline $\begin{array}{l}\text { Polypogon } \\
\text { monspeliensis }\end{array}$ & & Rabbitfoot grass & Poaceae - Grass Family & I & W & AG \\
\hline $\begin{array}{l}\text { Schizachyrium } \\
\text { scoparium }\end{array}$ & $\begin{array}{l}\text { Andropogon } \\
\text { scoparius }\end{array}$ & Little bluestem & Poaceae - Grass Family & $\mathrm{N}$ & W & PG \\
\hline Sorghastrum nutans & & Indian-grass & Poaceae - Grass Family & $\mathrm{N}$ & W & PG \\
\hline Ranunculus sp. & & Buttercup & Ranunculaceae - Buttercup Family & $\mathrm{N}$ & NA & PF \\
\hline
\end{tabular}


Table 2. Mesic Mixed Grassland

\begin{tabular}{|l|l|l|l|c|c|c|}
\hline \multicolumn{7}{|c|}{ NREL National Wind Technology Center } \\
\hline \multicolumn{1}{|c|}{ Scientific Binomial } & Synonomy & \multicolumn{1}{|c|}{ Common Name } & \multicolumn{2}{c|}{ Family } & Origin & Season \\
\hline Geum aleppicum & & Avens & Rosaceae - Rose Family & Form \\
\hline Rosa sayi & Rosa acicularis & Prickly wild rose & Rosaceae - Rose Family & NA & PF \\
\hline Commandra umbellata & & Bastard-toadflax & Santalaceae - Sandelwood Family & N & NA & S \\
\hline Verbascum thapsis & & Common mullein & Scropulariaceae - Figwort Family & NA & PF \\
\hline Veronica peregrina & & Purslane speedwell & Scropulariaceae - Figwort Family & NA & BF \\
\hline Typha latifolia & & Common cattail & Typhaceae - Cattail Family & NA & AF \\
\hline
\end{tabular}




\section{Table 3. Ponderosa Pine Woodland}

\begin{tabular}{|c|c|c|c|c|c|c|}
\hline \multicolumn{7}{|c|}{$\begin{array}{l}\text { Plant Species List } \\
\text { NREL National Wind Technology Center }\end{array}$} \\
\hline Scientific Binomial & Synonomy & Common Name & Family & Origin & Season & $\begin{array}{l}\text { Life } \\
\text { Form }\end{array}$ \\
\hline Yucca glauca & & Yucca & Agavaceae - Agave Family & $\mathrm{N}$ & NA & SU \\
\hline Allium textile & & Wild onion & Alliaceae - Onion Family & $\mathrm{N}$ & NA & $\mathrm{PF}$ \\
\hline Cerastrium strictum & & Mouse-ear & Alsinaceae - Chickweed Family & $\mathrm{N}$ & NA & PF \\
\hline Eremogone fendleri & & Desert sandwort & Alsinaceae - Chickweed Family & $\mathrm{N}$ & NA & $\mathrm{PF}$ \\
\hline Eremogone hookeri & Arenaria hookeri & Desert sandwort & Alsinaceae - Chickweed Family & $\mathrm{N}$ & NA & PF \\
\hline Paronychia jamesii & & James' nailwort & Alsinaceae - Chickweed Family & $\mathrm{N}$ & NA & $\mathrm{PF}$ \\
\hline $\begin{array}{l}\text { Rhus aromatica var. } \\
\text { trilobata }\end{array}$ & & Skunkbrush & Anacardiaceae - Sumac Family & $\mathrm{N}$ & NA & S \\
\hline Toxicodendron rydbergii & & Poison ivy & Anacardiaceae - Sumac Family & $\mathrm{N}$ & NA & $\mathrm{S}$ \\
\hline Harbouria trachypleura & & Whisk broom parsley & Apiaceae - Parsley Family & $\mathrm{N}$ & NA & PF \\
\hline Apocynum cannabinum & & Indian hemp & Apocynaceae - Dogbane Family & $\mathrm{N}$ & NA & $\mathrm{PF}$ \\
\hline Achillea lanulosa & & Yarrow & Asteraceae - Sunflower Family & $\mathrm{N}$ & NA & PF \\
\hline Acosta diffusa & Centaurea diffusa & Diffuse knapweed & Asteraceae - Sunflower Family & $\mathrm{I}$ & NA & $\mathrm{BF} / \mathrm{PF}$ \\
\hline Ambrosia psilostachya & & Western ragweed & Asteraceae - Sunflower Family & $\mathrm{N}$ & NA & PF \\
\hline Antennaria rosea & & Pussytoes & Asteraceae - Sunflower Family & $\mathrm{N}$ & NA & $\mathrm{PF}$ \\
\hline Artemisia absinthium & & Wormwood & Asteraceae - Sunflower Family & $\mathrm{N}$ & NA & PFISS \\
\hline Artemisia ludoviciana & & Prairie sagewort & Asteraceae - Sunflower Family & $\mathrm{N}$ & NA & PF \\
\hline Aster ericoides & & White aster & Asteraceae - Sunflower Family & $\mathrm{N}$ & NA & PF \\
\hline Brickellia eupatorioides & & Brickellia & Asteraceae - Sunflower Family & $\mathrm{N}$ & NA & PF \\
\hline Breea arvensis & Cirsium arvense & Canada thistle & Asteraceae - Sunflower Family & I & NA & PF \\
\hline Cirsium undulatum & & Wavyleaf thistle & Asteraceae - Sunflower Family & $\mathrm{N}$ & NA & $\mathrm{BF}$ \\
\hline Grindelia revoluta & & Gumweed & Asteraceae - Sunflower Family & $\mathrm{N}$ & NA & PF \\
\hline Grindelia squarrosa & & Curlycup gumweed & Asteraceae - Sunflower Family & $\mathrm{N}$ & NA & $\mathrm{BF}$ \\
\hline Gutierrezia sarothrae & & Broom snakeweed & Asteraceae - Sunflower Family & $\mathrm{N}$ & NA & SS \\
\hline Heterotheca villosa & Chrysopsis villosa & Hairy golden aster & Asteraceae - Sunflower Family & $\mathrm{N}$ & NA & SS \\
\hline Lactuca serriola & & Prickly lettuce & Asteraceae - Sunflower Family & 1 & NA & $\mathrm{BF}$ \\
\hline Liatris punctata & & Dotted gayfeather & Asteraceae - Sunflower Family & $\mathrm{N}$ & NA & PF \\
\hline $\begin{array}{l}\text { Oligosporus } \\
\text { dracunculus }\end{array}$ & $\begin{array}{l}\text { Artemisia } \\
\text { dracunculus }\end{array}$ & Wild tarragon & Asteraceae - Sunflower Family & $\mathrm{N}$ & NA & PF \\
\hline Senecio crassulus & & Butterweed & Asteraceae - Sunflower Family & $\mathrm{N}$ & NA & PF \\
\hline Senecio spartioides & & Groundsel & Asteraceae - Sunflower Family & $\mathrm{N}$ & NA & PF/SS \\
\hline Solidago mollis & & Soft goldenrod & Asteraceae - Sunflower Family & $\mathrm{N}$ & NA & PF \\
\hline Taraxacum officinale & & Common dandelion & Asteraceae - Sunflower Family & $\mathrm{I}$ & NA & $\mathrm{PF}$ \\
\hline Cynoglossum officinale & & Houndstongue & Boraginaceae - Borage Family & $\mathrm{I}$ & NA & $\mathrm{BF}$ \\
\hline Lithospermum incisum & & Narrowleaf gromwell & Boraginaceae - Borage Family & $\mathrm{N}$ & NA & PF \\
\hline Alyssum alyssoides & & Pale alyssum & Brassicaceae - Mustard Family & $\mathrm{I}$ & NA & $\mathrm{AF}$ \\
\hline Erysimum capitatum & & Western wallflower & Brassicaceae - Mustard Family & $\mathrm{N}$ & NA & $\mathrm{BF}$ \\
\hline $\begin{array}{l}\text { Coryphantha vivipara } \\
\text { var. vivipara }\end{array}$ & & Nipple cactus & Cactaceae - Cactus Family & $\mathrm{N}$ & NA & SU \\
\hline $\begin{array}{l}\text { Echinocereus } \\
\text { viridiflorus }\end{array}$ & & Hen-and-chicks & Cactaceae - Cactus Family & $\mathrm{N}$ & NA & SU \\
\hline Opuntia macrorhiza & & Plains prickly pear & Cactaceae - Cactus Family & $\mathrm{N}$ & NA & SU \\
\hline
\end{tabular}




\section{Table 3. Ponderosa Pine Woodland}

\begin{tabular}{|c|c|c|c|c|c|c|}
\hline \multicolumn{7}{|c|}{$\begin{array}{c}\text { Plant Species List } \\
\text { NREL National Wind Technology Center }\end{array}$} \\
\hline Scientific Binomial & Synonomy & Common Name & Family & Origin & Season & $\begin{array}{l}\text { Life } \\
\text { Form }\end{array}$ \\
\hline Opuntia polyacantha & & Plains prickly pear & Cactaceae - Cactus Family & $\mathrm{N}$ & NA & SU \\
\hline Campanula rotundifolia & & Common harebell & Campanulaceae - Bellflower Family & $\mathrm{N}$ & NA & PF \\
\hline $\begin{array}{l}\text { Symphoricarpos } \\
\text { occidentalis }\end{array}$ & & Western snowberry & Caprifoliaceae - Honeysuckle Family & $\mathrm{N}$ & NA & $\mathrm{S}$ \\
\hline Townsendia hookeri & & Easter daisy & Asteraceae - Sunflower Family & $\mathrm{N}$ & NA & $\mathrm{PF}$ \\
\hline $\begin{array}{l}\text { Symphoricarpos } \\
\text { occidentalis }\end{array}$ & & Western snowberry & Caprifoliaceae - Honeysuckle Family & $\mathrm{N}$ & NA & $\mathrm{S}$ \\
\hline Chenopodium album & & Common lambsquarters & Chenopodiaceae - Goosefoot Family & $\mathrm{I}$ & NA & $\mathrm{AF}$ \\
\hline Convolvulus arvensis & & Field bindweed & Convolvulaceae - Morning Glory Family & $\mathrm{I}$ & NA & $\mathrm{PF}$ \\
\hline Carex brevior & & Sedge & Cyperaceae - Sedge Family & $\mathrm{N}$ & NA & $P G$ \\
\hline Carex filifolia & & Thread-leafed sedge & Cyperaceae - Sedge Family & $\mathrm{N}$ & NA & PG \\
\hline Carex sp. & & Sedge & Cyperaceae - Sedge Family & $\mathrm{N}$ & NA & PG \\
\hline Astragalus mollissimus & & Wooly locoweed & Fabaceae - Pea Family & $\mathrm{N}$ & NA & PF \\
\hline Dalea purpurea & $\begin{array}{l}\text { Petalostemon } \\
\text { purpurea }\end{array}$ & Purple prairie clover & Fabaceae - Pea Family & $\mathrm{N}$ & NA & PF \\
\hline Lupinus argenteus & & Silver lupine & Fabaceae - Pea Family & $\mathrm{N}$ & NA & PF \\
\hline Oxytropis lambertii & & Lambert locoweed & Fabaceae - Pea Family & $\mathrm{N}$ & NA & PF \\
\hline Psoralidium tenuiflora & & Slimflower scurfpea & Fabaceae - Pea Family & $\mathrm{N}$ & NA & PF \\
\hline Thermopsis rhombifolia & & Prairie goldenpea & Fabaceae - Pea Family & $\mathrm{N}$ & NA & PF \\
\hline Frasera speciosa & & Monument plant & Gentianaceae - Gentian Family & $\mathrm{N}$ & NA & PF \\
\hline Pneumonanthe affinis & Gentiana affinis & Bottle gentian & Gentianaceae - Gentian Family & $\mathrm{N}$ & NA & PF \\
\hline Geranium caespitosum & & Wild geranium & Geraniaceae - Geranium Family & $\mathrm{N}$ & NA & PF \\
\hline $\begin{array}{l}\text { Geranium } \\
\text { viscosissimum }\end{array}$ & & Sticky geranium & Geraniaceae - Geranium Family & $\mathrm{N}$ & NA & PF \\
\hline Ribes aureum & & Golden current & Grossulariaceae - Current Family & $\mathrm{N}$ & NA & $\mathrm{S}$ \\
\hline Ribes cereum & & Wax current & Grossulariaceae - Current Family & $\mathrm{N}$ & NA & $\mathrm{S}$ \\
\hline Delphinium nuttallianum & & Blue larkspur & Helleboraceae - Hellebore Family & $\mathrm{N}$ & NA & PF \\
\hline Phacelia heterophylla & Phacelia hastata & Scorpioweed & Hydrophyllaceae - Waterleaf Family & $\mathrm{N}$ & NA & PF \\
\hline Hypericum perforatum & & St. Johnswort & Hypericaceae - St. Johnswort family & $\mathrm{I}$ & NA & PF \\
\hline Monarda fistulosa & & Bee balm & Lamiaceae - Mint Family & $\mathrm{N}$ & NA & $\mathrm{PF}$ \\
\hline Leucocrinum montanum & & Sand lily & Liliaceae - Lily Family & $\mathrm{N}$ & NA & PF \\
\hline Calylophus serrulatus & & $\begin{array}{l}\text { Shrubby evening- } \\
\text { primrose }\end{array}$ & Onagraceae - Evening-primrose Family & $\mathrm{N}$ & NA & SS \\
\hline Oenothera coronopifolia & & $\begin{array}{l}\text { Combleaf evening- } \\
\text { primrose }\end{array}$ & Onagraceae - Evening-primrose Family & $\mathrm{N}$ & NA & PF \\
\hline Oxalis dillenii & & Woodsorrel & Oxalidaceae - Woodsorrel Family & $\mathrm{N}$ & NA & $\mathrm{PF}$ \\
\hline Pinus ponderosa & & Ponderosa pine & Pinaceae - Pine Family & $\mathrm{N}$ & NA & $\mathrm{T}$ \\
\hline Pseudotsuga menziesii & & Douglas-fir & Pinaceae - Pine Family & $\mathrm{N}$ & NA & $\mathrm{T}$ \\
\hline Agropyron cristatum & & Crested wheatgrass & Poaceae - Grass Family & $\mathrm{I}$ & $\mathrm{C}$ & $P G$ \\
\hline Agrostis scabra & & Ticklegrass & Poaceae - Grass Family & $\mathrm{N}$ & $\mathrm{C}$ & PG \\
\hline Andropogon gerardii & & Big bluestem & Poaceae - Grass Family & $\mathrm{N}$ & $\mathrm{W}$ & PG \\
\hline Anisantha tectorum & Bromus tectorum & Cheatgrass & Poaceae - Grass Family & $\mathrm{I}$ & $\mathrm{C}$ & AG \\
\hline
\end{tabular}




\section{Table 3. Ponderosa Pine Woodland}

\begin{tabular}{|c|c|c|c|c|c|c|}
\hline \multicolumn{7}{|c|}{$\begin{array}{c}\text { Plant Species List } \\
\text { NREL National Wind Technology Center }\end{array}$} \\
\hline Scientific Binomial & Synonomy & Common Name & Family & Origin & Season & $\begin{array}{l}\text { Life } \\
\text { Form }\end{array}$ \\
\hline Aristida purpurea & & Three-awn & Poaceae-Grass Family & $\mathrm{N}$ & $\mathrm{W}$ & $P G$ \\
\hline Bouteloua curtipendula & & Side-oats grama & Poaceae - Grass Family & $\mathrm{N}$ & $\mathrm{W}$ & $P G$ \\
\hline Bromopis inermis & Bromus inermis & Smooth bromegrass & Poaceae - Grass Family & $\mathrm{I}$ & $\mathrm{C}$ & $P G$ \\
\hline Chondrosum gracile & Bouteloua gracilis & Blue grama & Poaceae - Grass Family & $\mathrm{N}$ & $\mathrm{W}$ & $P G$ \\
\hline Critesion jubatum & Hordeum jubatum & Foxtail barley & Poaceae - Grass Family & $\mathrm{N}$ & $\mathrm{C}$ & PG \\
\hline Elymus elymoides & Sitanion hystrix & Bottletail squirreltail & Poaceae - Grass Family & $\mathrm{N}$ & C & PG \\
\hline Hesperostipa comata & Stipa comata & Needle-and-thread & Poaceae - Grass Family & $\mathrm{N}$ & $\mathrm{C}$ & $P G$ \\
\hline Koeleria macrantha & Koeleria pyramidata & Junegrass & Poaceae - Grass Family & $\mathrm{N}$ & $\mathrm{C}$ & $P G$ \\
\hline Muhlenbergia 10ontana & & Mountain muhly & Poaceae - Grass Family & $\mathrm{N}$ & W & $P G$ \\
\hline Nassella viridula & Stipa viridula & Green needlegrass & Poaceae - Grass Family & $\mathrm{N}$ & $\mathrm{C}$ & PG \\
\hline Pascopyrum smithii & Agropyron smithii & Western wheatgrass & Poaceae - Grass Family & $\mathrm{N}$ & $\mathrm{C}$ & $\mathrm{PG}$ \\
\hline Poa compressa & & Canada bluegrass & Poaceae - Grass Family & 1 & $\mathrm{C}$ & $P G$ \\
\hline Poa pratensis & & Kentucky bluegrass & Poaceae - Grass Family & $\mathrm{I}$ & $\mathrm{C}$ & $P G$ \\
\hline $\begin{array}{l}\text { Schizachyrium } \\
\text { scoparium }\end{array}$ & $\begin{array}{l}\text { Andropogon } \\
\text { scoparius }\end{array}$ & Little bluestem & Poaceae - Grass Family & $\mathrm{N}$ & W & $P G$ \\
\hline Pulsatilla patens & Anemone patens & Pasque flower & Ranunculaceae - Buttercup Family & $\mathrm{N}$ & NA & PF \\
\hline Amelanchier utahensis & & Serviceberry & Rosaceae - Rose Family & $\mathrm{N}$ & NA & $\mathrm{S}$ \\
\hline $\begin{array}{l}\text { Cerasus pumila subsp. } \\
\text { besseyi }\end{array}$ & $\begin{array}{l}\text { Prunus pumila var. } \\
\text { bessyi }\end{array}$ & Sand cherry & Rosaceae - Rose Family & $\mathrm{N}$ & NA & $\mathrm{S}$ \\
\hline Crataegus erythropoda & & Hawthorn & Rosaceae - Rose Family & $\mathrm{N}$ & NA & $\mathrm{T}$ \\
\hline Drymocallis fissa & Potentilla fissa & Cinquefoil & Rosaceae - Rose Family & $\mathrm{N}$ & NA & $\mathrm{PF}$ \\
\hline Oreobatus deliciosus & Rubus deliciousus & Boulder raspberry & Rosaceae - Rose Family & $\mathrm{N}$ & NA & $\mathrm{S}$ \\
\hline Padus virginiana & Prunus virginiana & Chokecherry & Rosaceae - Rose Family & $\mathrm{N}$ & NA & $\mathrm{S}$ \\
\hline Potentilla hippiana & & Wooly cinquefoil & Rosaceae - Rose Family & $\mathrm{N}$ & NA & $\mathrm{PF}$ \\
\hline Potentilla ovina & & Potentilla & Rosaceae - Rose Family & $\mathrm{N}$ & NA & PF \\
\hline Potentilla recta & & Sulfur cinquefoil & Rosaceae - Rose Family & $\mathrm{I}$ & NA & PF \\
\hline Rosa arkansana & & Prairie rose & Rosaceae - Rose Family & $\mathrm{N}$ & NA & $\mathrm{S}$ \\
\hline Rosa woodsii & & Woods rose & Rosaceae - Rose Family & $\mathrm{N}$ & NA & $\mathrm{S}$ \\
\hline Galium aparine & & Catchweed bedstraw & Rubiaceae - Madder Family & 1 & NA & AF \\
\hline Galium septentrionale & & Northern bedstraw & Rubiaceae - Madder Family & $\mathrm{N}$ & NA & PF \\
\hline Commandra umbellata & & Bastard-toadflax & Santalaceae - Sandelwood Family & $\mathrm{N}$ & NA & $\mathrm{PF}$ \\
\hline $\begin{array}{l}\text { Penstemon } \\
\text { secundiflorus }\end{array}$ & & Penstemon & Scrophulariaceae - Figwort Family & $\mathrm{N}$ & NA & PF \\
\hline Penstemon virgatus & & Penstemon & Scrophulariaceae - Figwort Family & $\mathrm{N}$ & NA & $\mathrm{PF}$ \\
\hline Verbascum blattaria & & Moth mullein & Scrophulariaceae - Figwort Family & $\mathrm{I}$ & NA & $\mathrm{BF}$ \\
\hline Verbascum thapsus & & Common mullein & Scrophulariaceae - Figwort Family & $\mathrm{I}$ & NA & $\mathrm{BF}$ \\
\hline Viola nuttallii & & Yellow prairie violet & Violaceae - Violet Family & $\mathrm{N}$ & NA & PF \\
\hline
\end{tabular}


Table 4. Upland Shrubland

\begin{tabular}{|c|c|c|c|c|c|c|}
\hline \multicolumn{7}{|c|}{$\begin{array}{c}\text { Plant Species List } \\
\text { NREL National Wind Technology Center }\end{array}$} \\
\hline Scientific Binomial & Synonomy & Common Name & Family & Origin & Season & $\begin{array}{l}\text { Life } \\
\text { Form }\end{array}$ \\
\hline Cerastrium strictum & & Mouse-ear & Alsinaceae - Chickweed Family & $\mathrm{N}$ & NA & $\mathrm{PF}$ \\
\hline Eremogone fendleri & & Desert sandwort & Alsinaceae - Chickweed Family & $\mathrm{N}$ & NA & PF \\
\hline Paronychia jamesii & & James' nailwort & Alsinaceae - Chickweed Family & $\mathrm{N}$ & NA & $\mathrm{PF}$ \\
\hline $\begin{array}{l}\text { Rhus aromatica var. } \\
\text { trilobata }\end{array}$ & & Skunkbrush & Anacardiaceae - Sumac Family & $\mathrm{N}$ & NA & $\mathrm{S}$ \\
\hline Toxicodendron rydbergii & & Poison ivy & Anacardiaceae - Sumac Family & $\mathrm{N}$ & NA & $\mathrm{S}$ \\
\hline Lomatium orientale & & Lomatium & Apiaceae - Parsley Family & $\mathrm{N}$ & NA & $\mathrm{PF}$ \\
\hline Achillea lanulosa & & Yarrow & Asteraceae - Sunflower Family & $\mathrm{N}$ & NA & PF \\
\hline Acosta diffusa & Centaurea diffusa & Diffuse knapweed & Asteraceae - Sunflower Family & $\mathrm{I}$ & NA & $\mathrm{BF} / \mathrm{PF}$ \\
\hline Ambrosia psilostachya & & Western ragweed & Asteraceae - Sunflower Family & $\mathrm{N}$ & NA & PF \\
\hline Antennaria rosea & & Pussytoes & Asteraceae - Sunflower Family & $\mathrm{N}$ & NA & PF \\
\hline Artemisia frigida & & Fringed sagebrush & Asteraceae - Sunflower Family & $\mathrm{N}$ & NA & SS \\
\hline Artemisia ludoviciana & & Prairie sagewort & Asteraceae - Sunflower Family & $\mathrm{N}$ & NA & PF \\
\hline Aster porteri & & White aster & Asteraceae - Sunflower Family & $\mathrm{N}$ & NA & PF \\
\hline Carduus nutans & & Musk thistle & Asteraceae - Sunflower Family & 1 & NA & $\mathrm{BF}$ \\
\hline Cirsium undulatum & & Wavyleaf thistle & Asteraceae - Sunflower Family & $\mathrm{N}$ & NA & $\mathrm{BF}$ \\
\hline Gallardia aristata & & Blanketflower & Asteraceae - Sunflower Family & $\mathrm{N}$ & NA & PF \\
\hline Grindelia squarrosa & & Curlycup gumweed & Asteraceae - Sunflower Family & $\mathrm{N}$ & NA & $\mathrm{BF}$ \\
\hline Gutierrezia sarothrae & & Broom snakeweed & Asteraceae - Sunflower Family & $\mathrm{N}$ & NA & SS \\
\hline Helianthus rigidus & & Stiff sunflower & Asteraceae - Sunflower Family & $\mathrm{N}$ & NA & PF \\
\hline Heterotheca villosa & Chrysopsis villosa & Hairy golden aster & Asteraceae - Sunflower Family & $\mathrm{N}$ & NA & SS \\
\hline Lactuca serriola & & Prickly lettuce & Asteraceae - Sunflower Family & 1 & NA & $\mathrm{BF}$ \\
\hline Liatris punctata & & Dotted gayfeather & Asteraceae - Sunflower Family & $\mathrm{N}$ & NA & $\mathrm{PF}$ \\
\hline Oligosporus dracunculus & Artemisia dracunculus & Wild tarragon & Asteraceae - Sunflower Family & $\mathrm{N}$ & NA & PF \\
\hline Senecio crassulus & & Butterweed & Asteraceae - Sunflower Family & $\mathrm{N}$ & NA & $\mathrm{PF}$ \\
\hline Solidago missouriensis & & Prairie goldenrod & Asteraceae - Sunflower Family & $\mathrm{N}$ & NA & PF \\
\hline Solidago mollis & & Soft goldenrod & Asteraceae - Sunflower Family & $\mathrm{N}$ & NA & PF \\
\hline $\begin{array}{l}\text { Solidago speciosa var. } \\
\text { pallida }\end{array}$ & & Goldenrod & Asteraceae - Sunflower Family & $\mathrm{N}$ & NA & PF \\
\hline Tragopogon dubius & & Goatsbeard & Asteraceae - Sunflower Family & $\mathrm{I}$ & NA & $\mathrm{BF}$ \\
\hline Cynoglossum officinale & & Houndstongue & Boraginaceae - Borage Family & 1 & NA & $\mathrm{BF}$ \\
\hline Alyssum sp. & & Alyssum & Brassicaceae - Mustard Family & $\mathrm{I}$ & NA & $\mathrm{AF}$ \\
\hline Erysimum capitatum & & Western wallflower & Brassicaceae - Mustard Family & $\mathrm{N}$ & NA & $\mathrm{BF}$ \\
\hline Sisymbrium altissimum & & Tumbling mustard & Brassicaceae - Mustard Family & $\mathrm{I}$ & NA & $\mathrm{AF}$ \\
\hline Echinocereus viridiflorus & & Hen-and-chicks & Cactaceae - Cactus Family & $\mathrm{N}$ & NA & SU \\
\hline Opuntia polyacantha & & Plains prickly pear & Cactaceae - Cactus Family & $\mathrm{N}$ & NA & SU \\
\hline Campanula rotundifolia & & Common harebell & Campanulaceae - Bellflower Family & $\mathrm{N}$ & NA & PF \\
\hline $\begin{array}{l}\text { Symphoricarpos } \\
\text { occidentalis }\end{array}$ & & Western snowberry & Caprifoliaceae - Honeysuckle Family & $\mathrm{N}$ & NA & $\mathrm{S}$ \\
\hline Bassia sieversiana & Kochia scoparia & Kochia & Chenopodiaceae - Goosefoot Family & 1 & NA & AF \\
\hline Carex brevior & & Sedge & Cyperaceae - Sedge Family & $\mathrm{N}$ & NA & PG \\
\hline
\end{tabular}


Table 4. Upland Shrubland

Plant Species List

\begin{tabular}{|c|c|c|c|c|c|c|}
\hline \multicolumn{7}{|c|}{$\begin{array}{c}\text { Plant Species List } \\
\text { NREL National Wind Technology Center }\end{array}$} \\
\hline Scientific Binomial & Synonomy & Common Name & Family & Origin & Season & $\begin{array}{l}\text { Life } \\
\text { Form }\end{array}$ \\
\hline Carex filifolia & & Thread-leafed sedge & Cyperaceae - Sedge Family & $\mathrm{N}$ & NA & PG \\
\hline Euphorbia esula & & Leafy spurge & Euphobiaceae - Spurge Family & $\mathrm{I}$ & NA & $\mathrm{PF}$ \\
\hline Dalea purpurea & $\begin{array}{l}\text { Petalostemon } \\
\text { purpurea }\end{array}$ & Purple prairie clover & Fabaceae - Pea Family & $\mathrm{N}$ & NA & PF \\
\hline Oxytropis lambertii & & Lambert locoweed & Fabaceae - Pea Family & $\mathrm{N}$ & NA & PF \\
\hline Psoralidium tenuiflora & & Slimflower scurfpea & Fabaceae - Pea Family & $\mathrm{N}$ & NA & PF \\
\hline Thermopsis divaricarpa & & Prairie goldenpea & Fabaceae - Pea Family & $\mathrm{N}$ & NA & PF \\
\hline Pneumonanthe affinis & Gentiana affinis & Bottle gentian & Gentianaceae - Gentian Family & $\mathrm{N}$ & NA & PF \\
\hline Ribes cereum & & Wax current & Grossulariaceae - Current Family & $\mathrm{N}$ & NA & $\mathrm{S}$ \\
\hline Delphinium nuttallianum & & Blue larkspur & Helleboraceae - Hellebore Family & $\mathrm{N}$ & NA & $\mathrm{PF}$ \\
\hline Hypericum perforatum & & St. Johnswort & Hypericaceae - St. Johnswort family & I & NA & PF \\
\hline Leucocrinum montanum & & Sand lily & Liliaceae - Lily Family & $\mathrm{N}$ & NA & $\mathrm{PF}$ \\
\hline Linum lewisii & & Perennial flax & Linaceaea - Flax Family & $\mathrm{N}$ & NA & PF \\
\hline Calylophus serrulatus & & Shrubby evening-primrose & Onagraceae - Evening-primrose Family & $\mathrm{N}$ & NA & SS \\
\hline Pinus ponderosa & & Ponderosa pine & Pinaceae - Pine Family & $\mathrm{N}$ & NA & $\mathrm{T}$ \\
\hline Andropogon gerardii & & Big bluestem & Poaceae - Grass Family & $\mathrm{N}$ & $\mathrm{W}$ & $P G$ \\
\hline Anisantha tectorum & Bromus tectorum & Cheatgrass & Poaceae - Grass Family & $\mathrm{I}$ & $\mathrm{C}$ & AG \\
\hline Bromopis inermis & Bromus inermis & Smooth bromegrass & Poaceae - Grass Family & $\mathrm{I}$ & $\mathrm{C}$ & PG \\
\hline Bouteloua curtipendula & & Side-oats grama & Poaceae - Grass Family & $\mathrm{N}$ & W & PG \\
\hline Chondrosum gracile & Bouteloua gracilis & Blue grama & Poaceae - Grass Family & $\mathrm{N}$ & $\mathrm{W}$ & PG \\
\hline Critesion jubatum & Hordeum jubatum & Foxtail barley & Poaceae - Grass Family & $\mathrm{N}$ & $\mathrm{C}$ & $P G$ \\
\hline Elymus canadensis & & Canada wild rye & Poaceae - Grass Family & $\mathrm{N}$ & $\mathrm{C}$ & $P G$ \\
\hline Elymus elymoides & Sitonion hystrix & Bottlebrush squirreltail & Poaceae - Grass Family & $\mathrm{N}$ & $\mathrm{C}$ & PG \\
\hline Hesperostipa comata & Stipa comata & Needle-and-thread & Poaceae - Grass Family & $\mathrm{N}$ & $\mathrm{C}$ & PG \\
\hline Koeleria macrantha & Koeleria pyramidata & Junegrass & Poaceae - Grass Family & $\mathrm{N}$ & $\mathrm{C}$ & PG \\
\hline Muhlenbergia montana & & Mountain muhly & Poaceae - Grass Family & $\mathrm{N}$ & W & PG \\
\hline Nassella viridula & Stipa viridula & Green needlegrass & Poaceae - Grass Family & & & \\
\hline Pascopyrum smithii & Agropyron smithii & Western wheatgrass & Poaceae - Grass Family & $\mathrm{N}$ & $\mathrm{C}$ & PG \\
\hline Poa compressa & & Canada bluegrass & Poaceae - Grass Family & $\mathrm{I}$ & $\mathrm{C}$ & $P G$ \\
\hline Poa pratense & & Kentucky bluegrass & Poaceae - Grass Family & 1 & $\mathrm{C}$ & $P G$ \\
\hline $\begin{array}{l}\text { Schizachyrium } \\
\text { scoparium }\end{array}$ & $\begin{array}{l}\text { Andropogon } \\
\text { scoparius }\end{array}$ & Little bluestem & Poaceae - Grass Family & $\mathrm{N}$ & W & PG \\
\hline Sorghastrum nutans & & Indian-grass & Poaceae - Grass Family & $\mathrm{N}$ & W & PG \\
\hline Eriogonum umbellatum & & Wild buckwheat & Polygonaceae - Buckwheat Family & $\mathrm{N}$ & NA & $\mathrm{PF}$ \\
\hline Pterogonum alatum & Erigeron alatum & Winged buckwheat & Polygonaceae - Buckwheat Family & $\mathrm{N}$ & NA & PF \\
\hline Amelanchier utahensis & & Serviceberry & Rosaceae - Rose Family & $\mathrm{N}$ & NA & $\mathrm{S}$ \\
\hline $\begin{array}{l}\text { Cerasus pumila subsp. } \\
\text { besseyi }\end{array}$ & $\begin{array}{l}\text { Prunus pumila var. } \\
\text { bessyi }\end{array}$ & Sand cherry & Rosaceae - Rose Family & $\mathrm{N}$ & NA & $\mathrm{S}$ \\
\hline Crataegus erythropoda & & Hawthorn & Rosaceae - Rose Family & $\mathrm{N}$ & NA & $\mathrm{T}$ \\
\hline Padus virginiana & Prunus virginiana & Chokecherry & Rosaceae - Rose Family & $\mathrm{N}$ & NA & $\mathrm{S}$ \\
\hline Potentilla ovina & & Potentilla & Rosaceae - Rose Family & $\mathrm{N}$ & NA & PF \\
\hline Potentilla recta & & Sulfur cinquefoil & Rosaceae - Rose Family & $\mathrm{I}$ & NA & PF \\
\hline
\end{tabular}


Table 4. Upland Shrubland

\begin{tabular}{|c|c|c|c|c|c|c|}
\hline \multicolumn{7}{|c|}{$\begin{array}{c}\text { Plant Species List } \\
\text { NREL National Wind Technology Center }\end{array}$} \\
\hline Scientific Binomial & Synonomy & Common Name & Family & Origin & Season & $\begin{array}{c}\text { Life } \\
\text { Form }\end{array}$ \\
\hline Prunus americana & & Wild plum & Rosaceae - Rose Family & $\mathrm{N}$ & NA & $\mathrm{S}$ \\
\hline Rosa arkansana & & Prairie rose & Rosaceae - Rose Family & $\mathrm{N}$ & NA & $\mathrm{S}$ \\
\hline Rosa woodsii & & Woods rose & Rosaceae - Rose Family & $\mathrm{N}$ & NA & $\mathrm{S}$ \\
\hline Commandra umbellata & & Bastard-toadflax & Santalaceae - Sandelwood Family & $\mathrm{N}$ & NA & PF \\
\hline Castilleja sessiliflora & & Downy paintbrush & Scrophulariaceae - Figwort Family & $\mathrm{N}$ & NA & PF \\
\hline $\begin{array}{l}\text { Linerea genestifolia } \\
\text { subsp. dalmatica }\end{array}$ & Linerea dalmatica & Dalmatian toadflax & Scrophulariaceae - Figwort Family & 1 & NA & PF \\
\hline $\begin{array}{l}\text { Penstemon } \\
\text { secundiflorus }\end{array}$ & & Penstemon & Scrophulariaceae - Figwort Family & $\mathrm{N}$ & NA & PF \\
\hline Penstemon virgatus & & Penstemon & Scrophulariaceae - Figwort Family & $\mathrm{N}$ & NA & $\mathrm{PF}$ \\
\hline Verbascum thapsus & & Common mullein & Scrophulariaceae - Figwort Family & $\mathrm{I}$ & NA & $\mathrm{BF}$ \\
\hline
\end{tabular}


Table 5. Palustrine Emergent Wetland

\begin{tabular}{|c|c|c|c|c|c|c|}
\hline \multicolumn{7}{|c|}{$\begin{array}{l}\text { Plant Species List } \\
\text { NREL National Wind Technology Center }\end{array}$} \\
\hline Scientific Binomial & Synonomy & Common Name & Family & Origin & Season & $\begin{array}{l}\text { Life } \\
\text { Form }\end{array}$ \\
\hline Breea arvensis & Cirsium arvense & Canada thistle & Asteraceae - Sunflower Family & 1 & NA & $\mathrm{PF}$ \\
\hline Cardamine breweri & & Bittercress & Brassicaceae - Mustard Family & $\mathrm{N}$ & NA & PF \\
\hline Neolepia campestre & Lepidium campestre & Fieldcress & Brassicaceae - Mustard Family & $\mathrm{I}$ & NA & $\mathrm{BF}$ \\
\hline $\begin{array}{l}\text { Symphoricarpos } \\
\text { occidentalis }\end{array}$ & & Western snowberry & Caprifoliaceae - Honeysuckle Family & $\mathrm{N}$ & NA & S \\
\hline Carex nebrascensis & & Nebraska sedge & Cyperaceae - Sedge Family & $\mathrm{N}$ & NA & $P G$ \\
\hline Eleocharis palustris & & Spike-rush & Cyperaceae - Sedge Family & $\mathrm{N}$ & NA & PG \\
\hline Scirpus pallidus & & Bulrush & Cyperaceae - Sedge Family & $\mathrm{N}$ & NA & $P G$ \\
\hline Juncus arcticus & & Rush & Juncaceae - Rush Family & $\mathrm{N}$ & NA & $P G$ \\
\hline Juncus balticus & & Baltic rush & Juncaceae - Rush Family & $\mathrm{N}$ & NA & PG \\
\hline Juncus effusus & & Rush & Juncaceae - Rush Family & $\mathrm{N}$ & NA & PG \\
\hline Juncus longistylis & & Rush & Juncaceae - Rush Family & $\mathrm{N}$ & NA & $P G$ \\
\hline Juncus tenuis & & Rush & Juncaceae - Rush Family & $\mathrm{N}$ & NA & $P G$ \\
\hline Juncus torreyi & & Torrey's rush & Juncaceae - Rush Family & $\mathrm{N}$ & NA & PG \\
\hline Marrubium vulgare & & Horehound & Lamiaceae - Mint Family & $\mathrm{I}$ & NA & PF \\
\hline Mentha arvensis & & Fieldmint & Lamiaceae - Mint Family & $\mathrm{N}$ & NA & PF \\
\hline Epilobium cilatum & & Willow herb & Onagraceae - Evening-primrose Family & $\mathrm{N}$ & NA & $\mathrm{PF}$ \\
\hline Oenothera villosa & & Common evening-primrose & Onagraceae - Evening-primrose Family & $\mathrm{N}$ & NA & PF \\
\hline Andropogon gerardii & & Big bluestem & Poaceae - Grass Family & $\mathrm{N}$ & W & $P G$ \\
\hline Anisantha tectorum & Bromus tectorum & Cheatgrass & Poaceae - Grass Family & $\mathrm{I}$ & $\mathrm{C}$ & AG \\
\hline Critesion jubatum & Hordeum jubatum & Foxtail barley & Poaceae - Grass Family & $\mathrm{N}$ & $\mathrm{C}$ & PG \\
\hline Koeleria macrantha & Koeleria pyramidata & Junegrass & Poaceae - Grass Family & $\mathrm{N}$ & C & PG \\
\hline Pascopyrum smithii & Agropyron smithii & Western wheatgrass & Poaceae - Grass Family & $\mathrm{N}$ & $\mathrm{C}$ & PG \\
\hline Poa compressa & & Canada bluegrass & Poaceae - Grass Family & I & $\mathrm{C}$ & PG \\
\hline Poa pratensis & & Kentucky bluegrass & Poaceae - Grass Family & $\mathrm{I}$ & $\mathrm{C}$ & $P G$ \\
\hline $\begin{array}{l}\text { Polypogon } \\
\text { monspeliensis }\end{array}$ & & Rabbitfoot grass & Poaceae - Grass Family & I & W & AG \\
\hline $\begin{array}{l}\text { Schizachyrium } \\
\text { scoparium }\end{array}$ & $\begin{array}{l}\text { Andropogon } \\
\text { scoparius }\end{array}$ & Little bluestem & Poaceae - Grass Family & $\mathrm{N}$ & W & PG \\
\hline Geum aleppicum & & Yellow avens & Rosaceae - Rose Family & $\mathrm{N}$ & NA & $\mathrm{PF}$ \\
\hline $\begin{array}{l}\text { Padus virginiana subsp. } \\
\text { melanocarpa }\end{array}$ & Prunus virginiana & Chokecherry & Rosaceae - Rose Family & $\mathrm{N}$ & NA & $\mathrm{s}$ \\
\hline Galium aparine & & Catchweed bedstraw & Rubiaceae - Madder Family & $\mathrm{I}$ & NA & $\mathrm{AF}$ \\
\hline Populus angustifolia & & Narrowleaf cottonwood & Salicaceae - Willow Family & $\mathrm{N}$ & NA & $\mathrm{T}$ \\
\hline Salix amygdaloides & & Peach-leaf willow & Salicaceae - Willow Family & $\mathrm{N}$ & NA & $T$ \\
\hline Salix exigua & & Sandbar willow & Salicaceae - Willow Family & $\mathrm{N}$ & NA & $\mathrm{S}$ \\
\hline Veronica peregrina & & Purslane speedwell & Scropulariaceae - Figwort Family & $\mathrm{N}$ & NA & $\mathrm{AF}$ \\
\hline Typha latifolia & & Common cattail & Typhaceae - Cattail Family & $\mathrm{N}$ & NA & $\mathrm{PF}$ \\
\hline Typha angustifolia & & Narrow-leaved cattail & Typhaceae - Cattail Family & $\mathrm{N}$ & NA & PF \\
\hline
\end{tabular}


Table 6. Riparian Fringe Wetland

\begin{tabular}{|c|c|c|c|c|c|c|}
\hline \multicolumn{7}{|c|}{$\begin{array}{l}\text { Plant Species List } \\
\text { NREL National Wind Technology Center }\end{array}$} \\
\hline Scientific Binomial & Synonomy & Common Name & Family & Origin & Season & Life Form \\
\hline Lomatium orientale & & Lomatium & Apiaceae - Parsley Family & $\mathrm{N}$ & NA & PF \\
\hline Asclepias speciosa & & Showy milkweed & Asclepiadaceae - Milkweed Family & $\mathrm{N}$ & NA & PF \\
\hline Achillea lanulosa & & Yarrow & Asteraceae - Sunflower Family & $\mathrm{N}$ & NA & PF \\
\hline Acosta diffusa & Centaurea diffusa & Diffuse knapweed & Asteraceae - Sunflower Family & I & NA & $\mathrm{BF} / \mathrm{PF}$ \\
\hline Ambrosia psilostachya & & Western ragweed & Asteraceae - Sunflower Family & $\mathrm{N}$ & NA & $\mathrm{PF}$ \\
\hline Ambrosia trifida & & Giant ragweed & Asteraceae - Sunflower Family & $\mathrm{I}$ & NA & AF \\
\hline Arnica fulgens & & Arnica & Asteraceae - Sunflower Family & $\mathrm{N}$ & NA & PF \\
\hline Artemisia ludoviciana & Populus deltoides & Prairie sagewort & Asteraceae - Sunflower Family & $\mathrm{N}$ & NA & PF \\
\hline Aster ericoides & & White aster & Asteraceae - Sunflower Family & $\mathrm{N}$ & NA & PF \\
\hline Breea arvensis & Cirsium arvense & Canada thistle & Asteraceae - Sunflower Family & I & NA & PF \\
\hline Brickellia eupatorioides & & Brickellia & Asteraceae - Sunflower Family & $\mathrm{N}$ & NA & $\mathrm{PF}$ \\
\hline Carduus nutans & & Musk thistle & Asteraceae - Sunflower Family & I & NA & $\mathrm{BF}$ \\
\hline Cichorium intybus & & Chicory & Asteraceae - Sunflower Family & I & NA & PF \\
\hline Conyza canadensis & & Horseweed & Asteraceae - Sunflower Family & $\mathrm{N}$ & NA & AF \\
\hline Erigeron divergens & & Spreading fleabane & Asteraceae - Sunflower Family & $\mathrm{N}$ & NA & $\mathrm{BF}$ \\
\hline Gaillardia aristata & & Blanketflower & Asteraceae - Sunflower Family & $\mathrm{N}$ & NA & PF \\
\hline Grindelia squarrosa & & Curlycup gumweed & Asteraceae - Sunflower Family & $\mathrm{N}$ & NA & BF \\
\hline Helianthus annuus & & Common sunflower & Asteraceae - Sunflower Family & $\mathrm{N}$ & NA & $\mathrm{AF}$ \\
\hline Heterotheca villosa & Chrysopsis villosa & Hairy golden aster & Asteraceae - Sunflower Family & $\mathrm{N}$ & NA & SS \\
\hline Lactuca serriola & & Prickly lettuce & Asteraceae - Sunflower Family & 1 & NA & $\mathrm{BF}$ \\
\hline Liatris punctata & & Dotted gayfeather & Asteraceae - Sunflower Family & $\mathrm{N}$ & NA & PF \\
\hline Onopordum acanthium & & Scotch thistle & Asteraceae - Sunflower Family & $\mathrm{I}$ & NA & $\mathrm{BF}$ \\
\hline Ratibida columnifera & & Prairie coneflower & Asteraceae - Sunflower Family & $\mathrm{N}$ & NA & PF \\
\hline Senecio crassulus & & Butterweed & Asteraceae - Sunflower Family & $\mathrm{N}$ & NA & PF \\
\hline Senecio integerrimus & & Grounsel & Asteraceae - Sunflower Family & $\mathrm{N}$ & NA & $\mathrm{BF} / \mathrm{PF}$ \\
\hline Solidago missouriensis & & Prairie goldenrod & Asteraceae - Sunflower Family & $\mathrm{N}$ & NA & PF \\
\hline Tragopogon dubius & & Goatsbeard & Asteraceae - Sunflower Family & $\mathrm{I}$ & NA & $\mathrm{BF}$ \\
\hline Cynoglossum officinale & & Houndstongue & Boraginaceae - Borage Family & $\mathrm{I}$ & NA & $\mathrm{BF}$ \\
\hline Nasturtium officinale & & Watercress & Brassicaceae - Mustard Family & I & NA & PF \\
\hline Alyssum minus & & Alyssum & Brassicaceae - Mustard Family & $\mathrm{I}$ & NA & $\mathrm{AF}$ \\
\hline Neolepia campestre & Lepidium campestre & Fieldcress & Brassicaceae - Mustard Family & I & NA & $\mathrm{BF}$ \\
\hline Noccaea montana & & Wild candytuft & Brassicaceae - Mustard Family & $\mathrm{N}$ & NA & AF \\
\hline Rorippa sinuata & & Spreading yellowcress & Brassicaceae - Mustard Family & $\mathrm{N}$ & NA & PF \\
\hline Sisymbrium altissimum & & Tall tumblemustard & Brassicaceae - Mustard Family & $\mathrm{I}$ & NA & $\mathrm{AF}$ \\
\hline Thlaspi arvense & & $\begin{array}{l}\text { Field pennycress } \\
\text { (Fanweed) }\end{array}$ & Brassicaceae - Mustard Family & I & NA & AF \\
\hline Opuntia macrorhiza & & Plains prickly pear & Cactaceae - Cactus Family & $\mathrm{N}$ & NA & SU \\
\hline Campanula rotundifolia & & Common harebell & Campanulaceae - Bellflower Family & $\mathrm{N}$ & NA & PF \\
\hline Lobelia siphilitica & & Blue cardinal flower & Campanulaceae - Bellflower Family & $\mathrm{N}$ & NA & PF \\
\hline $\begin{array}{l}\text { Symphoricarpos } \\
\text { occidentalis }\end{array}$ & & Western snowberry & Caprifoliaceae - Honeysuckle Family & $\mathrm{N}$ & NA & $\mathrm{S}$ \\
\hline Saponaria officinalis & & Bouncing Bet & Caryophyllaceae - Pink Family & $\mathrm{I}$ & NA & PF \\
\hline
\end{tabular}


Table 6. Riparian Fringe Wetland

\begin{tabular}{|c|c|c|c|c|c|c|}
\hline \multicolumn{7}{|c|}{$\begin{array}{c}\text { Plant Species List } \\
\text { NREL National Wind Technology Center }\end{array}$} \\
\hline Scientific Binomial & Synonomy & Common Name & $\begin{array}{c}\text { Family } \\
\end{array}$ & Origin & Season & Life Form \\
\hline Bassia sieversiana & Kochia scoparia & Kochia & Chenopodiaceae - Goosefoot Family & 1 & NA & AF \\
\hline Chenopodium album & & Common lambsquarters & Chenopodiaceae - Goodefoot Family & I & NA & $\mathrm{AF}$ \\
\hline $\begin{array}{l}\text { Tradescantia } \\
\text { occidentalis }\end{array}$ & & Spiderwort & Commelinaceae - Spiderwort Family & $\mathrm{N}$ & NA & PF \\
\hline Maianthemum stellatum & Smilacina stellata & False solomon's seal & Convallariaceae - Mayflower Family & $\mathrm{N}$ & NA & PF \\
\hline Convolvulus arvensis & & Field bindweed & $\begin{array}{l}\text { Convolvulaceae - Morning Glory } \\
\text { Family }\end{array}$ & I & NA & PF \\
\hline Carex hystricina & & Sedge & Cyperaceae - Sedge Family & $\mathrm{N}$ & NA & PG \\
\hline Carex lanquinosa & & Sedge & Cyperaceae - Sedge Family & $\mathrm{N}$ & NA & PG \\
\hline Carex nebrascensis & & Nebraska sedge & Cyperaceae - Sedge Family & $\mathrm{N}$ & NA & PG \\
\hline Carex utriculata & Carex rostrata & Sedge & Cyperaceae - Sedge Family & $\mathrm{N}$ & NA & PG \\
\hline Eleocharis palustris & & Spike-rush & Cyperaceae - Sedge Family & $\mathrm{N}$ & NA & $\mathrm{PG}$ \\
\hline Dalea purpurea & $\begin{array}{l}\text { Petalostemon } \\
\text { purpurea }\end{array}$ & Purple prairie clover & Fabaceae - Pea Family & $\mathrm{N}$ & NA & PF \\
\hline Glycyrrhiza lepidota & & American licorice & Fabaceae - Pea Family & $\mathrm{N}$ & NA & PF \\
\hline Lupinus argenteus & & Silver lupine & Fabaceae - Pea Family & $\mathrm{N}$ & NA & PF \\
\hline Medicago sativa & & Alfalfa & Fabaceae - Pea Family & I & NA & $\mathrm{PF}$ \\
\hline Melilotus officinalis & & Yellow sweetclover & Fabaceae - Pea Family & $\mathrm{I}$ & NA & $\mathrm{BF}$ \\
\hline Psoralidium tenuiflora & & Slimflower scurfpea & Fabaceae - Pea Family & $\mathrm{N}$ & NA & PF \\
\hline Thermopsis rhombifolia & & Prairie goldenpea & Fabaceae - Pea Family & $\mathrm{N}$ & NA & PF \\
\hline Ribes aureum & & Golden current & Grossulariaceae - Current Family & $\mathrm{N}$ & NA & $\mathrm{S}$ \\
\hline Phacelia heterophylla & Phacelia hastata & Scorpionweed & Hydrophyllaceae - Waterleaf Family & $\mathrm{N}$ & NA & PF \\
\hline Hypericum perforatum & & St. Johnswort & Hypericaceae - St. Johnswort family & $\mathrm{I}$ & NA & PF \\
\hline Iris missouriensis & & Wild iris & Iridaceae - Iris Family & $\mathrm{N}$ & NA & PF \\
\hline Juncus nodosus & & Knotted rush & Juncaceae - Rush Family & $\mathrm{N}$ & NA & PG \\
\hline Carex simulata & & Rush & Juncaceae - Rush Family & $\mathrm{N}$ & NA & PG \\
\hline Juncus articulates & & Rush & Juncaceae - Rush Family & $\mathrm{N}$ & NA & PG \\
\hline Juncus balticus & & Baltic rush & Juncaceae - Rush Family & $\mathrm{N}$ & NA & PG \\
\hline Juncus bufonius & & Toad rush & Juncaceae - Rush Family & $\mathrm{N}$ & NA & AG \\
\hline Juncus effusus & & Rush & Juncaceae - Rush Family & $\mathrm{N}$ & NA & PG \\
\hline Juncus ensifolius & & Rush & Juncaceae - Rush Family & $\mathrm{N}$ & NA & PG \\
\hline Juncus longistylis & & Rush & Juncaceae - Rush Family & $\mathrm{N}$ & NA & PG \\
\hline Juncus sp. & & Rush & Juncaceae - Rush Family & $\mathrm{N}$ & NA & PG \\
\hline Marrubium vulgare & & Horehound & Lamiaceae - Mint Family & I & NA & PF \\
\hline Mentha arvensis & & Fieldmint & Lamiaceae - Mint Family & $\mathrm{N}$ & NA & PF \\
\hline Monarda fistulosa & & Bee balm & Lamiaceae - Mint Family & $\mathrm{N}$ & NA & PF \\
\hline Nepeta cataria & & Catnip & Lamiaceae - Mint Family & I & NA & PF \\
\hline Lemna turionifera & & Duckweed & Lemnaceae - Duckweed Family & $\mathrm{N}$ & NA & PF \\
\hline Calylophus serrulatus & & Shrubby evening-primrose & $\begin{array}{l}\text { Onagraceae - Evening-primrose } \\
\text { Family }\end{array}$ & $\mathrm{N}$ & NA & SS \\
\hline Epilobium cilatum & & Willow herb & $\begin{array}{l}\text { Onagraceae - Evening-primrose } \\
\text { Family }\end{array}$ & $\mathrm{N}$ & NA & PF \\
\hline
\end{tabular}


Table 6. Riparian Fringe Wetland

\begin{tabular}{|c|c|c|c|c|c|c|}
\hline \multicolumn{7}{|c|}{$\begin{array}{l}\text { Plant Species List } \\
\text { NREL National Wind Technology Center }\end{array}$} \\
\hline Scientific Binomial & Synonomy & Common Name & $\begin{array}{l}\text { Family } \\
\end{array}$ & Origin & Season & Life Form \\
\hline Gaura parviflora & & Smallflower gaura & $\begin{array}{l}\text { Onagraceae - Evening-primrose } \\
\text { Family }\end{array}$ & $\mathrm{N}$ & NA & $\mathrm{AF}$ \\
\hline Oenothera villosa & & $\begin{array}{l}\text { Common evening- } \\
\text { primrose }\end{array}$ & $\begin{array}{l}\text { Onagraceae - Evening-primrose } \\
\text { Family }\end{array}$ & $\mathrm{N}$ & NA & PF \\
\hline Oxalis dillenii & & Woodsorrel & Oxalidaceae - Woodsorrel Family & $\mathrm{N}$ & NA & PF \\
\hline $\begin{array}{l}\text { Argemone } \\
\text { polyanthemos }\end{array}$ & & Prickly poppy & Papaveracae - Poppy Family & $\mathrm{N}$ & NA & PF \\
\hline Pinus ponderosa & & Ponderosa pine & Pinaceae - Pine Family & $\mathrm{N}$ & NA & $\mathrm{T}$ \\
\hline Plantago lanceolata & & English plantain & Plantaginaceae - Plantain Family & 1 & NA & PF \\
\hline Plantago major & & Common plantain & Plantaginaceae - Plantain Family & $\mathrm{I}$ & NA & PF \\
\hline Agropyron cristatum & & Crested wheatgrass & Poaceae - Grass Family & $\mathrm{I}$ & $\mathrm{C}$ & PG \\
\hline Agrostis gigantea & Agrostis alba & Redtop & Poaceae - Grass Family & $\mathrm{I}$ & $\mathrm{C}$ & PG \\
\hline Agrostis scabra & & Ticklegrass & Poaceae - Grass Family & $\mathrm{N}$ & W & $\mathrm{PF}$ \\
\hline Andropogon gerardii & & Big bluestem & Poaceae - Grass Family & $\mathrm{N}$ & W & PG \\
\hline Anisantha tectorum & Bromus tectorum & Cheatgrass & Poaceae - Grass Family & $\mathrm{I}$ & $\mathrm{C}$ & $A G$ \\
\hline Bromopis inermis & Bromus inermis & Smooth bromegrass & Poaceae - Grass Family & $\mathrm{I}$ & C & PG \\
\hline Buchloë dactyloides & & Buffalograss & Poaceae - Grass Family & $\mathrm{N}$ & W & PG \\
\hline Critesion jubatum & Hordeum jubatum & Foxtail barley & Poaceae - Grass Family & $\mathrm{N}$ & $\mathrm{C}$ & PG \\
\hline Dactylis glomerata & & Orchard grass & Poaceae - Grass Family & $\mathrm{I}$ & C & PG \\
\hline Danthonia spicata & & Poverty oatgrass & Poaceae - Grass Family & $\mathrm{N}$ & $\mathrm{C}$ & PG \\
\hline Elymus trachycaulus & Agropyron caninum & Slender wheatgrass & Poaceae - Grass Family & $\mathrm{N}$ & $\mathrm{C}$ & $P G$ \\
\hline Festuca pratensis & & Meadow fescue & Poaceae - Grass Family & I & $\mathrm{C}$ & PG \\
\hline Glyceria grandis & & Tall mannagrass & Poaceae - Grass Family & $\mathrm{N}$ & W & $P G$ \\
\hline Glyceria striata & & Fowl mannagrass & Poaceae - Grass Family & $\mathrm{N}$ & $\mathrm{W}$ & PG \\
\hline Hesperostipa comata & Stipa comata & Needle-and-thread & Poaceae - Grass Family & $\mathrm{N}$ & $\mathrm{C}$ & $P G$ \\
\hline Koeleria macrantha & Koeleria pyramidata & Junegrass & Poaceae - Grass Family & $\mathrm{N}$ & $\mathrm{C}$ & PG \\
\hline Lophopyrum elongatum & Agropyron elongatum & Tall wheatgrass & Poaceae - Grass Family & $\mathrm{I}$ & $\mathrm{C}$ & PG \\
\hline Muhlenbergia filiformis & & Pull-up muhly & Poaceae - Grass Family & $\mathrm{N}$ & W & AG \\
\hline Muhlenbergia montana & & Mountain muhly & Poaceae - Grass Family & $\mathrm{N}$ & W & $P G$ \\
\hline Panicum virgatum & & Switchgrass & Poaceae - Grass Family & $\mathrm{N}$ & W & $P G$ \\
\hline Elymus canadensis & & Canada wild rye & Poaceae - Grass Family & $\mathrm{N}$ & $\mathrm{C}$ & $\mathrm{PG}$ \\
\hline Pascopyrum smithii & Agropyron smithii & Western wheatgrass & Poaceae - Grass Family & $\mathrm{N}$ & $\mathrm{C}$ & $P G$ \\
\hline Phleum pratense & & Common Timothy & Poaceae - Grass Family & $\mathrm{I}$ & $\mathrm{C}$ & PG \\
\hline Poa compressa & & Canada bluegrass & Poaceae - Grass Family & $\mathrm{I}$ & C & PG \\
\hline Poa fendleriana & & Muttongrass & Poaceae - Grass Family & $\mathrm{N}$ & $\mathrm{C}$ & $P G$ \\
\hline Poa pratensis & & Kentucky bluegrass & Poaceae - Grass Family & $\mathrm{I}$ & $\mathrm{C}$ & $P G$ \\
\hline $\begin{array}{l}\text { Schizachyrium } \\
\text { scoparium }\end{array}$ & $\begin{array}{l}\text { Andropogon } \\
\text { scoparius }\end{array}$ & Little bluestem & Poaceae - Grass Family & $\mathrm{N}$ & W & PG \\
\hline Sorghastrum nutans & & Indian-grass & Poaceae - Grass Family & $\mathrm{N}$ & W & PG \\
\hline Spartina pectinata & & Prairie cordgrass & Poaceae - Grass Family & $\mathrm{N}$ & $\mathrm{W}$ & $\mathrm{PG}$ \\
\hline Sporobolus airoides & & Alkaline sacatone & Poaceae - Grass Family & $\mathrm{N}$ & $\mathrm{W}$ & PG \\
\hline Sporobolus cryptandrus & & Sand dropseed & Poaceae - Grass Family & $\mathrm{N}$ & W & PG \\
\hline
\end{tabular}


Table 6. Riparian Fringe Wetland

\begin{tabular}{|c|c|c|c|c|c|c|}
\hline \multicolumn{7}{|c|}{$\begin{array}{l}\text { Plant Species List } \\
\text { NREL National Wind Technology Center }\end{array}$} \\
\hline Scientific Binomial & Synonomy & Common Name & Family & Origin & Season & Life Form \\
\hline Rumex crispus & & Curly dock & Polygonaceae - Buckwheat Family & $\mathrm{N}$ & NA & PF \\
\hline Clematis ligusticifolia & & Virgin's bower & Ranunculaceae - Buttercup Family & $\mathrm{N}$ & NA & $\mathrm{V}$ \\
\hline Agrimonia striata & & Agripmony & Rosaceae - Rose Family & $\mathrm{N}$ & NA & PF \\
\hline Geum macrophyllum & & Large-leaved avens & Rosaceae - Rose Family & $\mathrm{N}$ & NA & PF \\
\hline Padus virginiana & Prunus virginiana & Chokecherry & Rosaceae - Rose Family & $\mathrm{N}$ & NA & $\mathrm{S}$ \\
\hline Potentilla hippiana & & Wooly cinquefoil & Rosaceae - Rose Family & $\mathrm{N}$ & NA & PF \\
\hline Potentilla recta & & Sulfur cinquefoil & Rosaceae - Rose Family & $\mathrm{I}$ & NA & PF \\
\hline Rosa sayi & Rosa acicularis & Prickly wild rose & Rosaceae - Rose Family & $\mathrm{N}$ & NA & $\mathrm{S}$ \\
\hline Galium aparine & & Catchweed bedstraw & Rubiaceae - Madder Family & $\mathrm{I}$ & NA & $\mathrm{AF}$ \\
\hline Populus deltoides & & Plains cottonwood & Salicaceae - Willow Family & $\mathrm{N}$ & NA & $\mathrm{T}$ \\
\hline Salix alba var. vitellina & & Golden osier & Salicaceae - Willow Family & $\mathrm{I}$ & NA & $T$ \\
\hline Salix amygdaloides & & Peach-leaf willow & Salicaceae - Willow Family & $\mathrm{N}$ & NA & $T$ \\
\hline Salix exigua & & Sandbar willow & Salicaceae - Willow Family & $\mathrm{N}$ & NA & $S$ \\
\hline Salix fragilis & & Crack willow & Salicaceae - Willow Family & $\mathrm{I}$ & NA & $\mathrm{T}$ \\
\hline Verbascum blattaria & & Moth mullein & Scrophulariaceae - Figwort Family & $\mathrm{I}$ & NA & $\mathrm{BF}$ \\
\hline Verbascum thapsus & & Common mullein & Scrophulariaceae - Figwort Family & 1 & NA & $\mathrm{BF}$ \\
\hline Mimulus glabratus & & Monkeflower & Scropulariaceae - Figwort Family & $\mathrm{N}$ & NA & PF \\
\hline Veronica peregrina & & Purslane speedwell & Scropulariaceae - Figwort Family & $\mathrm{N}$ & NA & $\mathrm{AF}$ \\
\hline Typha angustifolia & & Narrow-leaved cattail & Typhaceae - Cattail Family & $\mathrm{N}$ & NA & PF \\
\hline Typha latifolia & & Common cattail & Typhaceae - Cattail Family & $\mathrm{N}$ & NA & PF \\
\hline
\end{tabular}


Table 7. Groundwater Seep Wetland

\begin{tabular}{|c|c|c|c|c|c|c|}
\hline \multicolumn{7}{|c|}{$\begin{array}{l}\text { Plant Species List } \\
\text { NREL National Wind Technology Center }\end{array}$} \\
\hline Scientific Binomial & Synonomy & Common Name & Family & Origin & Season & $\begin{array}{l}\text { Life } \\
\text { Form }\end{array}$ \\
\hline Apocynum cannabinum & & Indian hemp & Apocynaceae - Dogbane Family & $\mathrm{N}$ & NA & $\mathrm{PF}$ \\
\hline Asclepias speciosa & & Showy milkweed & Asclepiadaceae - Milkweed Family & $\mathrm{N}$ & NA & PF \\
\hline Arnica fulgens & & Arnica & Asteraceae - Sunflower Family & $\mathrm{N}$ & NA & $\mathrm{PF}$ \\
\hline Acosta diffusa & Centaurea diffusa & Diffuse knapweed & Asteraceae - Sunflower Family & 1 & NA & BF/PF \\
\hline Aster adscendens & Aster chilensis & Aster & Asteraceae - Sunflower Family & $\mathrm{N}$ & NA & PF \\
\hline Breea arvensis & Cirsium arvense & Canada thistle & Asteraceae - Sunflower Family & $\mathrm{I}$ & NA & PF \\
\hline Carduus nutans & & Musk thistle & Asteraceae - Sunflower Family & $\mathrm{I}$ & NA & $\mathrm{BF}$ \\
\hline Helianthus annuus & & Common sunflower & Asteraceae - Sunflower Family & $\mathrm{N}$ & NA & $\mathrm{AF}$ \\
\hline Solidago serotinoides & & Goldenrod & Asteraceae - Sunflower Family & $\mathrm{N}$ & NA & $\mathrm{PF}$ \\
\hline Xanthium strumarium & & Cocklebur & Asteraceae - Sunflower Family & $\mathrm{I}$ & NA & $\mathrm{AF}$ \\
\hline Cynoglossum officinale & & Houndstongue & Boraginaceae - Borage Family & $\mathrm{I}$ & NA & $\mathrm{BF}$ \\
\hline $\begin{array}{l}\text { Symphoricarpos } \\
\text { occidentalis }\end{array}$ & & Western snowberry & Caprifoliaceae - Honeysuckle Family & $\mathrm{N}$ & NA & $\mathrm{s}$ \\
\hline Bassia sieversiana & Kochia scoparia & Kochia & Chenopodiaceae - Goosefoot Family & $\mathrm{I}$ & NA & $\mathrm{AF}$ \\
\hline Carex languinosa & & Sedge & Cyperaceae - Sedge Family & $\mathrm{N}$ & NA & PG \\
\hline Carex nebrascensis & & Nebraska sedge & Cyperaceae - Sedge Family & $\mathrm{N}$ & NA & $\mathrm{PG}$ \\
\hline Carex utriculata & Carex rostrata & Sedge & Cyperaceae - Sedge Family & $\mathrm{N}$ & NA & PG \\
\hline Dipsacus fullonum & Dipsacus sylvestris & Common teasel & Dipsacaceae - Teasel Family & $\mathrm{I}$ & NA & $\mathrm{BF}$ \\
\hline Hippochaete laevigata & Equisetum laevigatum & Smooth scouring rush & Equisetaceae - Horsetail Family & $\mathrm{N}$ & NA & $\mathrm{AF}$ \\
\hline Amorpha fruticosa & & False indigo & Fabaceae - Pea Family & $\mathrm{N}$ & NA & $\mathrm{S}$ \\
\hline Glycyrrhiza lepidota & & American licorice & Fabaceae - Pea Family & $\mathrm{N}$ & NA & PF \\
\hline Melilotus albus & & White sweetclover & Fabaceae - Pea Family & 1 & NA & $\mathrm{BF}$ \\
\hline Melilotus officinalis & & Yellow sweetclover & Fabaceae - Pea Family & 1 & NA & $\mathrm{BF}$ \\
\hline Hypericum perforatum & & St. Johnswort & Hypericaceae - St. Johnswort family & $\mathrm{I}$ & NA & PF \\
\hline Iris missouriensis & & Wild iris & Iridaceae - Iris Family & $\mathrm{N}$ & NA & PF \\
\hline Juncus balticus & & Baltic rush & Juncaceae - Rush Family & $\mathrm{N}$ & NA & $P G$ \\
\hline Juncus effusus & & Rush & Juncaceae - Rush Family & $\mathrm{N}$ & NA & PG \\
\hline Marrubium vulgare & & Horehound & Lamiaceae - Mint Family & 1 & NA & PF \\
\hline Mentha arvensis & & Fieldmint & Lamiaceae - Mint Family & $\mathrm{N}$ & NA & PF \\
\hline Oenothera villosa & & Common evening-primrose & Onagraceae - Evening-primrose Family & $\mathrm{N}$ & NA & PF \\
\hline Plantago lanceolata & & English plantain & Plantaginaceae - Plantain Family & $\mathrm{I}$ & NA & PF \\
\hline Agrostis gigantea & Agrostis alba & Redtop & Poaceae - Grass Family & 1 & $\mathrm{C}$ & $P G$ \\
\hline Bromopis inermis & Bromus inermis & Smooth bromegrass & Poaceae - Grass Family & $\mathrm{I}$ & $\mathrm{C}$ & $P G$ \\
\hline Critesion jubatum & Hordeum jubatum & Foxtail barley & Poaceae - Grass Family & $\mathrm{N}$ & $\mathrm{C}$ & PG \\
\hline Dactylis glomerata & & Orchard grass & Poaceae - Grass Family & $\mathrm{I}$ & C & PG \\
\hline Nasselaa viridula & Stipa viridula & Green needlegrass & Poaceae - Grass Family & $\mathrm{N}$ & C & PG \\
\hline Panicum capillare & & Witchgrass & Poaceae - Grass Family & $\mathrm{N}$ & $\mathrm{W}$ & AG \\
\hline Panicum virgatum & & Switchgrass & Poaceae - Grass Family & $\mathrm{N}$ & W & PG \\
\hline Pascopyrum smithii & Agropyron smithii & Western wheatgrass & Poaceae - Grass Family & $\mathrm{N}$ & $\mathrm{C}$ & $P G$ \\
\hline Poa compressa & & Canada bluegrass & Poaceae - Grass Family & 1 & $\mathrm{C}$ & PG \\
\hline Poa pratensis & & Kentucky bluegrass & Poaceae - Grass Family & $\mathrm{I}$ & $\mathrm{C}$ & $P G$ \\
\hline Spartina pectinata & & Prairie cordgrass & Poaceae - Grass Family & $\mathrm{N}$ & $\mathrm{W}$ & PG \\
\hline
\end{tabular}


Table 7. Groundwater Seep Wetland

\begin{tabular}{|c|c|c|c|c|c|c|}
\hline \multicolumn{7}{|c|}{$\begin{array}{l}\text { Plant Species List } \\
\text { NREL National Wind Technology Center }\end{array}$} \\
\hline Scientific Binomial & Synonomy & Common Name & Family & Origin & Season & $\begin{array}{c}\text { Life } \\
\text { Form }\end{array}$ \\
\hline Geum macrophyllum & & Large-leaved avens & Rosaceae - Rose Family & $\mathrm{N}$ & NA & PF \\
\hline Prunus americana & & Wild plum & Rosaceae - Rose Family & $\mathrm{N}$ & NA & $\mathrm{S}$ \\
\hline Rosa sayi & Rosa acicularis & Prickly wild rose & Rosaceae - Rose Family & $\mathrm{N}$ & NA & $\mathrm{S}$ \\
\hline Rosa woodsii & & Woods rose & Rosaceae - Rose Family & $\mathrm{N}$ & NA & $\mathrm{S}$ \\
\hline Salix exigua & & Sandbar willow & Salicaceae - Willow Family & $\mathrm{N}$ & NA & $\mathrm{S}$ \\
\hline Verbascum blattaria & & Moth mullein & Scrophulariaceae - Figwort Family & $\mathrm{I}$ & NA & BF \\
\hline Verbascum thapsus & & Common mullein & Scrophulariaceae - Figwort Family & 1 & NA & $\mathrm{BF}$ \\
\hline Typha angustifolia & & Narrow-leaved cattail & Typhaceae - Cattail Family & $\mathrm{N}$ & NA & PF \\
\hline Typha latifolia & & Common cattail & Typhaceae - Cattail Family & $\mathrm{N}$ & NA & PF \\
\hline
\end{tabular}


Table 8. Seasonal Pond

\begin{tabular}{|c|c|c|c|c|c|c|}
\hline \multicolumn{7}{|c|}{$\begin{array}{l}\text { Plant Species List } \\
\text { NREL National Wind Technology Center }\end{array}$} \\
\hline Scientific Binomial & Synonomy & Common Name & Family & Origin & Season & $\begin{array}{l}\text { Life } \\
\text { Form }\end{array}$ \\
\hline Achillea lanulosa & & Yarrow & Asteraceae - Sunflower Family & $\mathrm{N}$ & NA & PF \\
\hline Acosta diffusa & Centaurea diffusa & Diffuse knapweed & Asteraceae - Sunflower Family & 1 & NA & $\mathrm{BF} / \mathrm{PF}$ \\
\hline Ambrosia psilostachya & & Western ragweed & Asteraceae - Sunflower Family & $\mathrm{N}$ & NA & PF \\
\hline Aster porteri & & White aster & Asteraceae - Sunflower Family & $\mathrm{N}$ & NA & PF \\
\hline Breea arvensis & Cirsium arvense & Canada thistle & Asteraceae - Sunflower Family & $\mathrm{I}$ & NA & $\mathrm{PF}$ \\
\hline Conyza canadensis & & Horseweed & Asteraceae - Sunflower Family & $\mathrm{N}$ & NA & $\mathrm{AF}$ \\
\hline Erigeron divergens & & Spreading fleabane & Asteraceae - Sunflower Family & $\mathrm{N}$ & NA & $\mathrm{BF}$ \\
\hline Grindelia squarrosa & & Curlycup gumweed & Asteraceae - Sunflower Family & $\mathrm{N}$ & NA & $\mathrm{BF}$ \\
\hline Helianthus annuus & & Common sunflower & Asteraceae - Sunflower Family & $\mathrm{N}$ & NA & $\mathrm{AF}$ \\
\hline Lactuca serriola & & Prickly lettuce & Asteraceae - Sunflower Family & $\mathrm{I}$ & NA & $\mathrm{BF}$ \\
\hline Oligosporus campestris & Artemisia campestris & Western sagewort & Asteraceae - Sunflower Family & $\mathrm{N}$ & NA & $\mathrm{BF}$ \\
\hline Xanthium strumarium & & Cocklebur & Asteraceae - Sunflower Family & $\mathrm{I}$ & NA & $\mathrm{AF}$ \\
\hline Alyssum minus & & Alyssum & Brassicaceae - Mustard Family & $\mathrm{I}$ & NA & $\mathrm{AF}$ \\
\hline Descurainia sp. & & Tansy mustard & Brassicaceae - Mustard Family & 1 & NA & $\mathrm{AF} / \mathrm{BF}$ \\
\hline Neolepia campestre & Lepidium campestre & Fieldcress & Brassicaceae - Mustard Family & $\mathrm{I}$ & NA & BF \\
\hline Sisymbrium altissimum & & Tumbling mustard & Brassicaceae - Mustard Family & 1 & NA & $\mathrm{AF}$ \\
\hline Thlaspi arvense & & Fanweed & Brassicaceae - Mustard Family & I & NA & AF \\
\hline Calochortus gunnisonii & & Mariposa lily & Calochortaceae - Mariposa Family & $\mathrm{N}$ & NA & PF \\
\hline Carex nebrascensis & & Nebraska sedge & Cyperaceae - Sedge Family & $\mathrm{N}$ & NA & PG \\
\hline Carex utriculata & Carex rostrata & Sedge & Cyperaceae - Sedge Family & $\mathrm{N}$ & NA & PG \\
\hline Eleocharis palustris & & Spike-rush & Cyperaceae - Sedge Family & $\mathrm{N}$ & NA & PG \\
\hline Dalea purpurea & $\begin{array}{l}\text { Petalostemon } \\
\text { purpurea }\end{array}$ & Purple prairie clover & Fabaceae - Pea Family & $\mathrm{N}$ & NA & PF \\
\hline Glycyrrhiza lepidota & & American licorice & Fabaceae - Pea Family & $\mathrm{N}$ & NA & PF \\
\hline Erodium cicutarium & & Filaree & Geraniaceae - Geranium Family & $\mathrm{I}$ & NA & $\mathrm{AF}$ \\
\hline Juncus balticus & & Baltic rush & Juncaceae - Rush Family & $\mathrm{N}$ & NA & PG \\
\hline Juncus effusus & & Rush & Juncaceae - Rush Family & $\mathrm{N}$ & NA & PG \\
\hline Agropyron cristatum & & Crested wheatgrass & Poaceae - Grass Family & $\mathrm{I}$ & $\mathrm{C}$ & PG \\
\hline Anisantha tectorum & Bromus tectorum & Cheatgrass & Poaceae - Grass Family & 1 & $\mathrm{C}$ & $A G$ \\
\hline Bromopsis inermis & Bromus inermis & Smooth brome & Poaceae - Grass Family & 1 & $\mathrm{C}$ & PG \\
\hline Critesion jubatum & Hordeum jubatum & Foxtail barley & Poaceae - Grass Family & $\mathrm{N}$ & $\mathrm{C}$ & PG \\
\hline Distichlis spicata & & Salt-grass & Poaceae-Grass Family & $\mathrm{N}$ & W & PG \\
\hline Koeleria macrantha & Koeleria pyramidata & Junegrass & Poaceae - Grass Family & $\mathrm{N}$ & $\mathrm{C}$ & PG \\
\hline Pascopyrum smithii & Agropyron smithii & Western wheatgrass & Poaceae - Grass Family & $\mathrm{N}$ & $\mathrm{C}$ & PG \\
\hline Poa compressa & & Canada bluegrass & Poaceae - Grass Family & $\mathrm{I}$ & $\mathrm{C}$ & PG \\
\hline Poa pratensis & & Kentucky bluegrass & Poaceae - Grass Family & 1 & $\mathrm{C}$ & PG \\
\hline Persicaria 21aculate & Polygonum persicaria & Lady's thumb & Polygonaceae - Buckwheat Family & I & NA & $\mathrm{AF}$ \\
\hline Persicaria pennsylvanica & $\begin{array}{l}\text { Polygonum } \\
\text { pennsylcanicum }\end{array}$ & Pennsylvania smartweed & Polygonaceae - Buckwheat Family & $\mathrm{N}$ & NA & PF \\
\hline Rumex crispus & & Curly dock & Polygonaceae - Buckwheat Family & $\mathrm{N}$ & NA & $\mathrm{PF}$ \\
\hline Agrimonia striata & & Agrimony & Rosaceae - Rose Family & $\mathrm{N}$ & NA & PF \\
\hline
\end{tabular}


Table 8. Seasonal Pond

\begin{tabular}{|c|c|c|c|c|c|c|}
\hline \multicolumn{7}{|c|}{$\begin{array}{l}\text { Plant Species List } \\
\text { NREL National Wind Technology Center }\end{array}$} \\
\hline Scientific Binomial & Synonomy & Common Name & Family & Origin & Season & $\begin{array}{c}\text { Life } \\
\text { Form }\end{array}$ \\
\hline Verbascum blattaria & & Moth mullein & Scrophulariaceae - Figwort Family & $\mathrm{I}$ & NA & BF \\
\hline Typha angustifolia & & Narrow-leaved cattail & Typhaceae - Cattail Family & $\mathrm{N}$ & NA & PF \\
\hline Typha latifolia & & Common cattail & Typhaceae - Cattail Family & $\mathrm{N}$ & NA & PF \\
\hline
\end{tabular}


Table 9. Disturbed

\begin{tabular}{|c|c|c|c|c|c|c|}
\hline \multicolumn{7}{|c|}{$\begin{array}{c}\text { Plant Species List } \\
\text { NREL National Wind Technology Center }\end{array}$} \\
\hline Scientific Binomial & Synonomy & Common Name & Family & Origin & Season & $\begin{array}{l}\text { Life } \\
\text { Form }\end{array}$ \\
\hline Yucca glauca & & Yucca & Agavaceae - Agave Family & $\mathrm{N}$ & NA & SU \\
\hline Paronychia jamesii & & James' nailwort & Alsinaceae - Chickweed Family & $\mathrm{N}$ & NA & PF \\
\hline Amaranthus retroflexus & & Redroot pigweed & Amaranthaceae - Amaranth Family & 1 & NA & $\mathrm{AF}$ \\
\hline Lomatium orientale & & Lomatium & Apiaceae - Parsley Family & $\mathrm{N}$ & NA & $\mathrm{PF}$ \\
\hline Apocynum cannabinum & & Indian hemp & Apocynaceae - Dogbane Family & $\mathrm{N}$ & NA & $\mathrm{PF}$ \\
\hline Asclepias speciosa & & Showy milkweed & Asclepiadaceae - Milkweed Family & $\mathrm{N}$ & NA & PF \\
\hline Achillea lanulosa & & Yarrow & Asteraceae - Sunflower Family & $\mathrm{N}$ & NA & PF \\
\hline Acosta diffusa & Centaurea diffusa & Diffuse knapweed & Asteraceae - Sunflower Family & $\mathrm{I}$ & NA & $\mathrm{BF} / \mathrm{PF}$ \\
\hline Ambrosia psilostachya & & Western ragweed & Asteraceae - Sunflower Family & $\mathrm{N}$ & NA & PF \\
\hline Artemisia frigida & & Fringed sagebrush & Asteraceae - Sunflower Family & $\mathrm{N}$ & NA & SS \\
\hline Artemisia ludoviciana & & Prairie sagewort & Asteraceae - Sunflower Family & $\mathrm{N}$ & NA & PF \\
\hline Aster ericoides & & White aster & Asteraceae - Sunflower Family & $\mathrm{N}$ & NA & PF \\
\hline Breea arvensis & Cirsium arvense & Canada thistle & Asteraceae - Sunflower Family & $\mathrm{I}$ & NA & PF \\
\hline Carduus nutans & & Musk thistle & Asteraceae - Sunflower Family & $\mathrm{I}$ & NA & $\mathrm{BF}$ \\
\hline Centaurea maculosa & & Spotted knapweed & Asteraceae - Sunflower Family & 1 & NA & PF \\
\hline Cichorium intybus & & Chicory & Asteraceae - Sunflower Family & 1 & NA & PF \\
\hline Conyza canadensis & & Horseweed & Asteraceae - Sunflower Family & $\mathrm{N}$ & NA & $\mathrm{AF}$ \\
\hline Dyssodia papposa & & Fetid marigold & Asteraceae - Sunflower Family & $\mathrm{N}$ & NA & PF \\
\hline Erigeron divergens & & Spreading fleabane & Asteraceae - Sunflower Family & $\mathrm{N}$ & NA & $\mathrm{BF}$ \\
\hline Grindelia squarrosa & & Curlycup gumweed & Asteraceae - Sunflower Family & $\mathrm{N}$ & NA & $\mathrm{BF}$ \\
\hline Gutierrezia sarothrae & & Broom snakeweed & Asteraceae - Sunflower Family & $\mathrm{N}$ & NA & SS \\
\hline Helianthus annuus & & Common sunflower & Asteraceae - Sunflower Family & $\mathrm{N}$ & NA & $\mathrm{AF}$ \\
\hline Lactuca serriola & & Prickly lettuce & Asteraceae - Sunflower Family & 1 & NA & $\mathrm{BF}$ \\
\hline Liatris punctata & & Dotted gayfeather & Asteraceae - Sunflower Family & $\mathrm{N}$ & NA & PF \\
\hline Ratibida columnifera & & Prairie coneflower & Asteraceae - Sunflower Family & $\mathrm{N}$ & NA & PF \\
\hline Solidago spathulata & & Goldenrod & Asteraceae - Sunflower Family & $\mathrm{N}$ & NA & PF \\
\hline Sonchus arvensis & & Field sow thistle & Asteraceae - Sunflower Family & 1 & NA & $\mathrm{PF}$ \\
\hline Taraxacum officinale & & Common dandelion & Asteraceae - Sunflower Family & 1 & NA & PF \\
\hline Xanthium strumarium & & Cocklebur & Asteraceae - Sunflower Family & 1 & NA & $\mathrm{AF}$ \\
\hline Lithospermum incisum & & Narrowleaf gromwell & Boraginaceae - Borage Family & $\mathrm{N}$ & NA & $\mathrm{PF}$ \\
\hline Alyssum alyssoides & & Pale alyssum & Brassicaceae - Mustard Family & 1 & NA & $\mathrm{AF}$ \\
\hline Cardaria draba & & Whitetop & Brassicaceae - Mustard Family & 1 & NA & PF \\
\hline Sisymbrium altissimum & & Tumbling mustard & Brassicaceae - Mustard Family & $\mathrm{I}$ & NA & $\mathrm{AF}$ \\
\hline Bassia sieversiana & Kochia scoparia & Kochia & Chenopodiaceae - Goosefoot Family & 1 & NA & AF \\
\hline Chenopodium murale & & Nettleleaf goosefoot & Chenopodiaceae - Goosefoot Family & 1 & NA & $\mathrm{AF}$ \\
\hline Kochia scoparia & Bassia sieversiana & Summer cypress & Chenopodiaceae - Goosefoot Family & 1 & NA & $\mathrm{AF}$ \\
\hline Salsola australis & Salsola iberica & Russian-thistle & Chenopodiaceae - Goosefoot Family & $\mathrm{I}$ & NA & $\mathrm{AF}$ \\
\hline Salsola iberica & & Russian-thistle & Chenopodiaceae - Goosefoot Family & $\mathrm{I}$ & NA & $\mathrm{AF}$ \\
\hline Teloxys botrys & & Woordseed & Chenopodiaceae - Goosefoot Family & $\mathrm{I}$ & NA & $\mathrm{AF}$ \\
\hline Convolvulus arvensis & & Field bindweed & Convolvulaceae - Morning Glory Family & $\mathrm{I}$ & NA & PF \\
\hline Carex brevior & & Sedge & Cyperaceae - Sedge Family & $\mathrm{N}$ & NA & PG \\
\hline Chamaesyce & Euphorbia & Ridgeseed spurge & Euphorbiaceae - Spurge Family & $\mathrm{I}$ & NA & $\mathrm{AF}$ \\
\hline
\end{tabular}


Table 9. Disturbed

\begin{tabular}{|c|c|c|c|c|c|c|}
\hline \multicolumn{7}{|c|}{$\begin{array}{l}\text { Plant Species List } \\
\text { NREL National Wind Technology Center }\end{array}$} \\
\hline Scientific Binomial & Synonomy & Common Name & Family & Origin & Season & $\begin{array}{c}\text { Life } \\
\text { Form }\end{array}$ \\
\hline glyptosperma & glyptosperma & & & & & \\
\hline Euphorbia esula & & Leafy spurge & Euphorbiaceae - Spurge Family & $\mathrm{I}$ & NA & PF \\
\hline Tithymalus brachyceras & & Spurge & Euphorbiaceae - Spurge Family & $\mathrm{N}$ & NA & $\mathrm{PF}$ \\
\hline Astragalus cicer & & Cicer milkvetch & Fabaceae - Pea Family & $\mathrm{I}$ & NA & $\mathrm{PF}$ \\
\hline Medicago sativa & & Alfalfa & Fabaceae - Pea Family & 1 & NA & PF \\
\hline Melilotus albus & & White sweetclover & Fabaceae - Pea Family & I & NA & $\mathrm{BF}$ \\
\hline Melilotus officinalis & & Yellow sweetclover & Fabaceae - Pea Family & I & NA & $\mathrm{BF}$ \\
\hline Oxytropis lambertii & & Lambert locoweed & Fabaceae - Pea Family & $\mathrm{N}$ & NA & $\mathrm{PF}$ \\
\hline Psoralidium tenuiflora & & Slimflower scurfpea & Fabaceae - Pea Family & $\mathrm{N}$ & NA & PF \\
\hline Trifolium pratense & & Red clover & Fabaceae - Pea Family & I & NA & PF \\
\hline Hypericum perforatum & & St. Johnswort & Hypericaceae - St. Johnswort family & $\mathrm{I}$ & NA & PF \\
\hline Juncus longistylis & & Rush & Juncaceae - Rush Family & $\mathrm{N}$ & NA & PG \\
\hline Leucocrinum montanum & & Sand lily & Liliaceae - Lily Family & $\mathrm{N}$ & NA & PF \\
\hline Linum lewisii & & Perennial flax & Linaceaea - Flax Family & $\mathrm{N}$ & NA & PF \\
\hline Calylophus serrulatus & & Shrubby evening-primrose & Onagraceae - Evening-primrose Family & $\mathrm{N}$ & NA & SS \\
\hline Gaura parviflora & & Smallflower gaura & Onagraceae - Evening-primrose Family & $\mathrm{N}$ & NA & $\mathrm{AF}$ \\
\hline Oxalis dillenii & & Woodsorrel & Oxalidaceae - Woodsorrel Family & $\mathrm{N}$ & NA & PF \\
\hline Plantago lanceolata & & English plantain & Plantaginaceae - Plantain Family & 1 & NA & $\mathrm{PF}$ \\
\hline Plantago major & & Common plantain & Plantaginaceae - Plantain Family & 1 & NA & PF \\
\hline Agropyron cristatum & & Crested wheatgrass & Poaceae - Grass Family & $\mathrm{I}$ & $\mathrm{C}$ & PG \\
\hline Andropogon gerardii & & Big bluestem & Poaceae - Grass Family & $\mathrm{N}$ & $\mathrm{W}$ & PG \\
\hline Anisantha tectorum & Bromus tectorum & Cheatgrass & Poaceae - Grass Family & 1 & $\mathrm{C}$ & AG \\
\hline Aristida purpurea & & Three-awn & Poaceae - Grass Family & $\mathrm{N}$ & W & PG \\
\hline Bouteloua curtipendula & & Side-oats grama & Poaceae - Grass Family & $\mathrm{N}$ & W & PG \\
\hline Bromopis inermis & Bromus inermis & Smooth bromegrass & Poaceae - Grass Family & $\mathrm{I}$ & $\mathrm{C}$ & PG \\
\hline Buchloë dactyloides & & Buffalograss & Poaceae - Grass Family & $\mathrm{N}$ & $\mathrm{W}$ & PG \\
\hline Chondrosum gracile & Bouteloua gracilis & Blue grama & Poaceae - Grass Family & $\mathrm{N}$ & W & PG \\
\hline Critesion jubatum & Hordeum jubatum & Foxtail barley & Poaceae - Grass Family & $\mathrm{N}$ & C & PG \\
\hline Dactylis glomerata & & Orchard grass & Poaceae - Grass Family & $\mathrm{I}$ & $\mathrm{C}$ & PG \\
\hline Echinochloa crusgalli & & Barnyard grass & Poaceae - Grass Family & 1 & $\mathrm{~W}$ & AG \\
\hline Elymus elymoides & Sitanion hystrix & Bottletail squirreltail & Poaceae - Grass Family & $\mathrm{N}$ & $\mathrm{C}$ & PG \\
\hline Elymus trachycaulus & Agropyron caninum & Slender wheatgrass & Poaceae - Grass Family & $\mathrm{N}$ & $\mathrm{C}$ & PG \\
\hline Elytrigia dasystachyum & $\begin{array}{l}\text { Agropyron } \\
\text { dasystachyum }\end{array}$ & Thickspike wheatgrass & Poaceae - Grass Family & $\mathrm{N}$ & $\mathrm{C}$ & $P G$ \\
\hline Eragrostis cilianensis & & Stinkgrass & Poaceae - Grass Family & $\mathrm{I}$ & W & AG \\
\hline Festuca ovina & & Sheep fescue & Poaceae - Grass Family & $\mathrm{N}$ & $\mathrm{C}$ & PG \\
\hline Hesperostipa comata & Stipa comata & Needle-and-thread & Poaceae - Grass Family & $\mathrm{N}$ & $\mathrm{C}$ & PG \\
\hline Koeleria macrantha & Koeleria pyramidata & Junegrass & Poaceae - Grass Family & $\mathrm{N}$ & C & PG \\
\hline Lophopyrum elongatum & Agropyron elongatum & Tall wheatgrass & Poaceae - Grass Family & $\mathrm{I}$ & $\mathrm{C}$ & $P G$ \\
\hline Muhlenbergia montana & & Mountain muhly & Poaceae - Grass Family & $\mathrm{N}$ & $\mathrm{W}$ & PG \\
\hline Panicum capillare & & Witchgrass & Poaceae - Grass Family & $\mathrm{N}$ & W & $A G$ \\
\hline Panicum virgatum & & Switchgrass & Poaceae - Grass Family & $\mathrm{N}$ & W & PG \\
\hline
\end{tabular}


Table 9. Disturbed

\begin{tabular}{|c|c|c|c|c|c|c|}
\hline \multicolumn{7}{|c|}{$\begin{array}{c}\text { Plant Species List } \\
\text { NREL National Wind Technology Center }\end{array}$} \\
\hline Scientific Binomial & Synonomy & Common Name & Family & Origin & Season & $\begin{array}{l}\text { Life } \\
\text { Form }\end{array}$ \\
\hline Pascopyrum smithii & Agropyron smithii & Western wheatgrass & Poaceae - Grass Family & $\mathrm{N}$ & $\mathrm{C}$ & PG \\
\hline Poa compressa & & Canada bluegrass & Poaceae - Grass Family & 1 & $\mathrm{C}$ & PG \\
\hline Poa fendleriana & & Muttongrass & Poaceae - Grass Family & $\mathrm{N}$ & C & PG \\
\hline Poa pratensis & & Kentucky bluegrass & Poaceae - Grass Family & $\mathrm{I}$ & $\mathrm{C}$ & PG \\
\hline $\begin{array}{l}\text { Schizachyrium } \\
\text { scoparium }\end{array}$ & $\begin{array}{l}\text { Andropogon } \\
\text { scoparius }\end{array}$ & Little bluestem & Poaceae - Grass Family & $\mathrm{N}$ & W & $P G$ \\
\hline Setaria viridis & & Green floxtail & Poaceae - Grass Family & I & W & AG \\
\hline Sporobolus cryptandrus & & Sand dropseed & Poaceae - Grass Family & $\mathrm{N}$ & W & PG \\
\hline Thinopyrum intermedium & $\begin{array}{l}\text { Agropyrum } \\
\text { intermedium }\end{array}$ & Intermediate wheatgrass & Poaceae - Grass Family & 1 & $\mathrm{C}$ & PG \\
\hline Triticum aestivum & & Wheat & Poaceae - Grass Family & $\mathrm{I}$ & C & AG \\
\hline Rumex crispus & & Curly dock & Polygonaceae - Buckwheat Family & $\mathrm{N}$ & NA & PF \\
\hline Potentilla hippiana & & Wooly cinquefoil & Rosaceae - Rose Family & $\mathrm{N}$ & NA & $\mathrm{P}$ \\
\hline Rosa arkansana & & Prairie rose & Rosaceae - Rose Family & $\mathrm{N}$ & NA & $\mathrm{S}$ \\
\hline Commandra umbellata & & Bastard-toadflax & Santalaceae - Sandelwood Family & $\mathrm{N}$ & NA & PF \\
\hline Verbascum blattaria & & Moth mullein & Scrophulariaceae - Figwort Family & $\mathrm{I}$ & NA & $\mathrm{BF}$ \\
\hline Verbascum thapsus & & Common mullein & Scrophulariaceae - Figwort Family & I & NA & $\mathrm{BF}$ \\
\hline Leiostemon ambiguum & & & Scropulariaceae - Figwort Family & $\mathrm{N}$ & NA & PF \\
\hline Physalis virginiana & & Virginia ground-cherry & Solanaceae - Nightshade Family & $\mathrm{I}$ & NA & PF \\
\hline Solanum rostratum & & Buffalobur & Solanaceae - Nightshade Family & $\mathrm{N}$ & NA & $\mathrm{AF}$ \\
\hline Verbena bracteata & & Prostrate verbena & Verbebaceae - Verbena Family & $\mathrm{N}$ & NA & PF \\
\hline Viola nuttallii & & Yellow prairie violet & Violaceae - Violet Family & $\mathrm{N}$ & NA & PF \\
\hline
\end{tabular}




\section{APPENDIX C}

Plant Community and Other Photos 


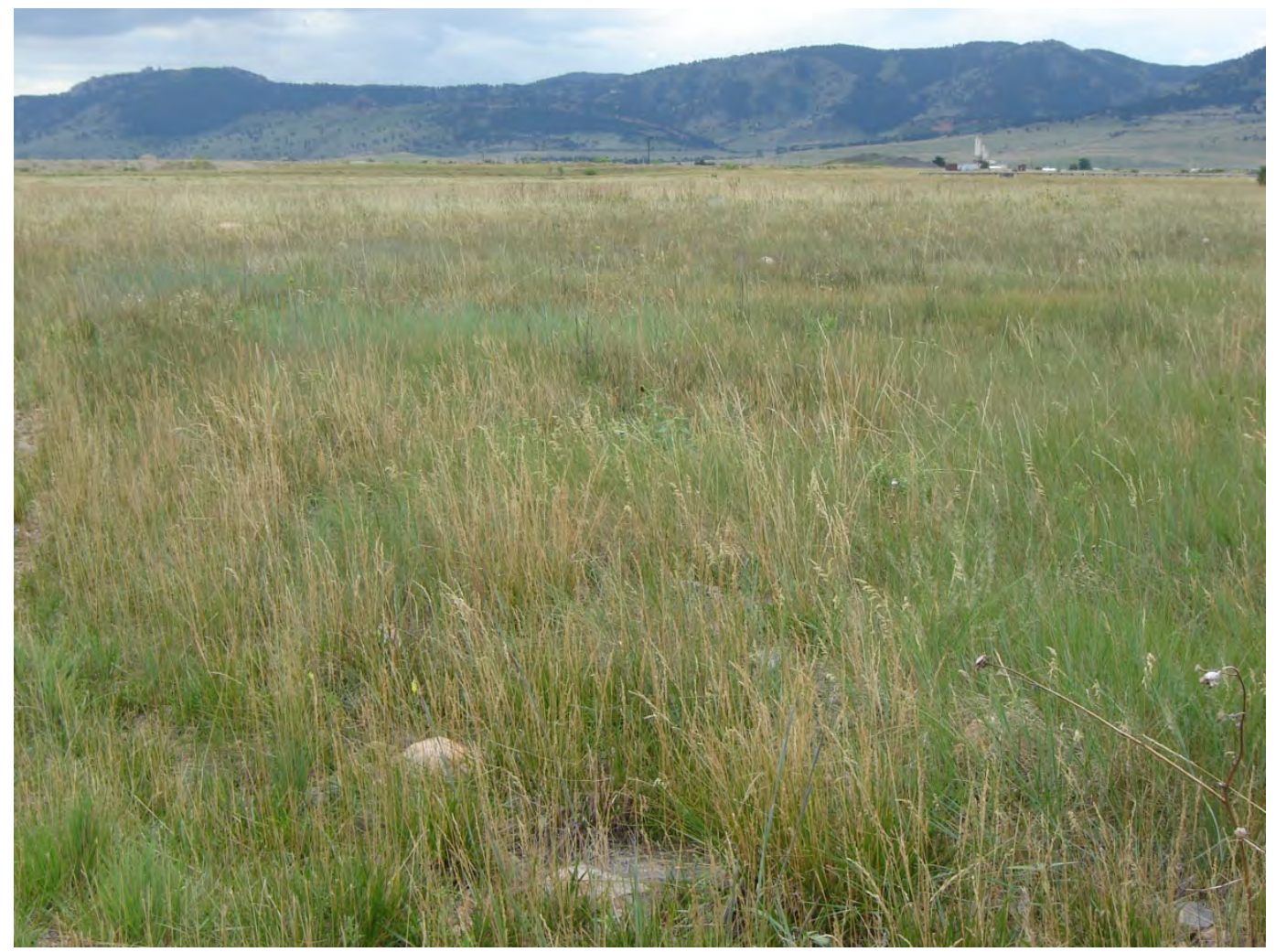

Photo 1. Looking southwest from Row 3 at the xeric mixed grassland community. August 5, 2010.

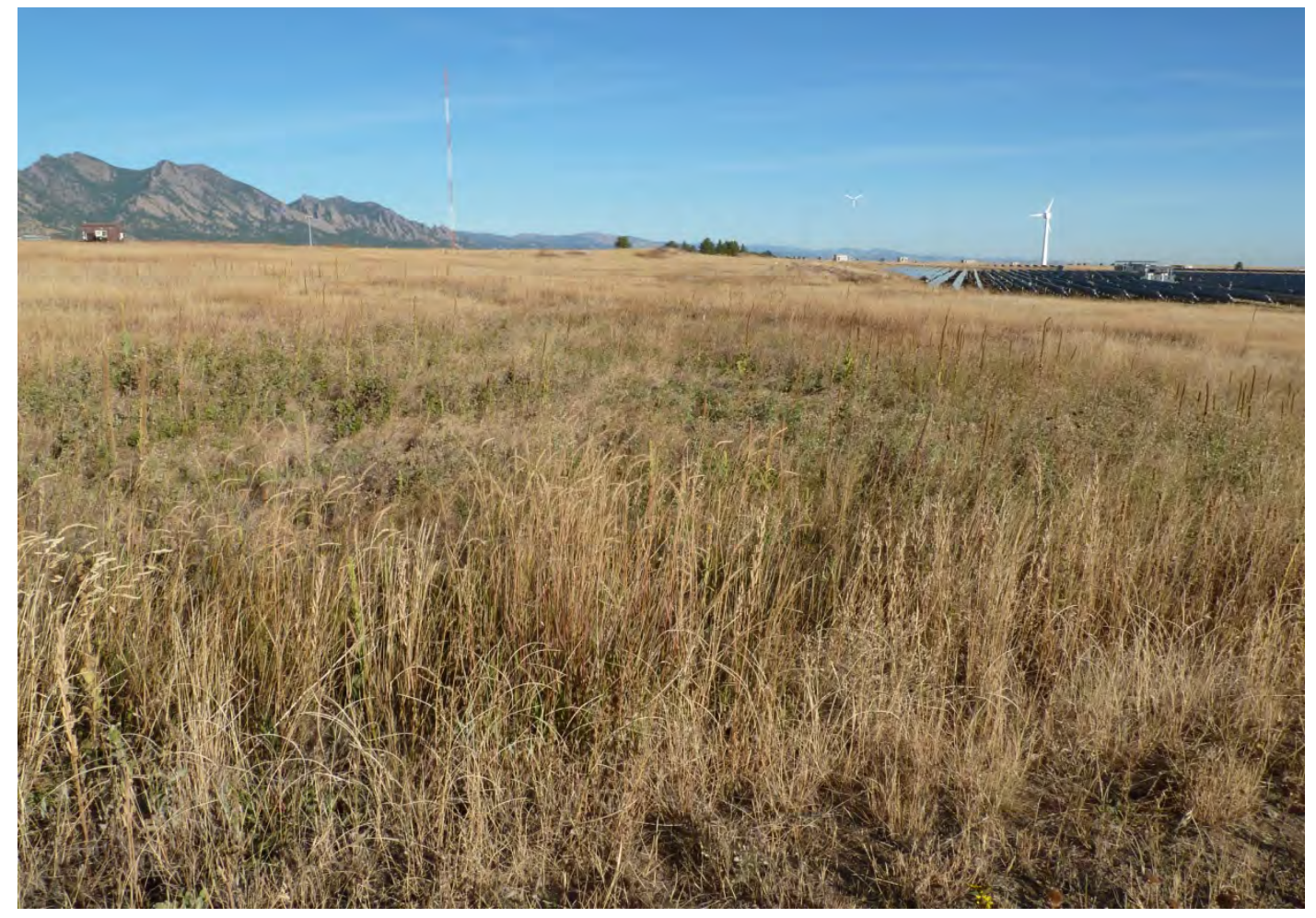

Photo 2. Looking northwest at the mesic mixed grassland community. The solar array is visible to the northeast. October 21, 2010. 


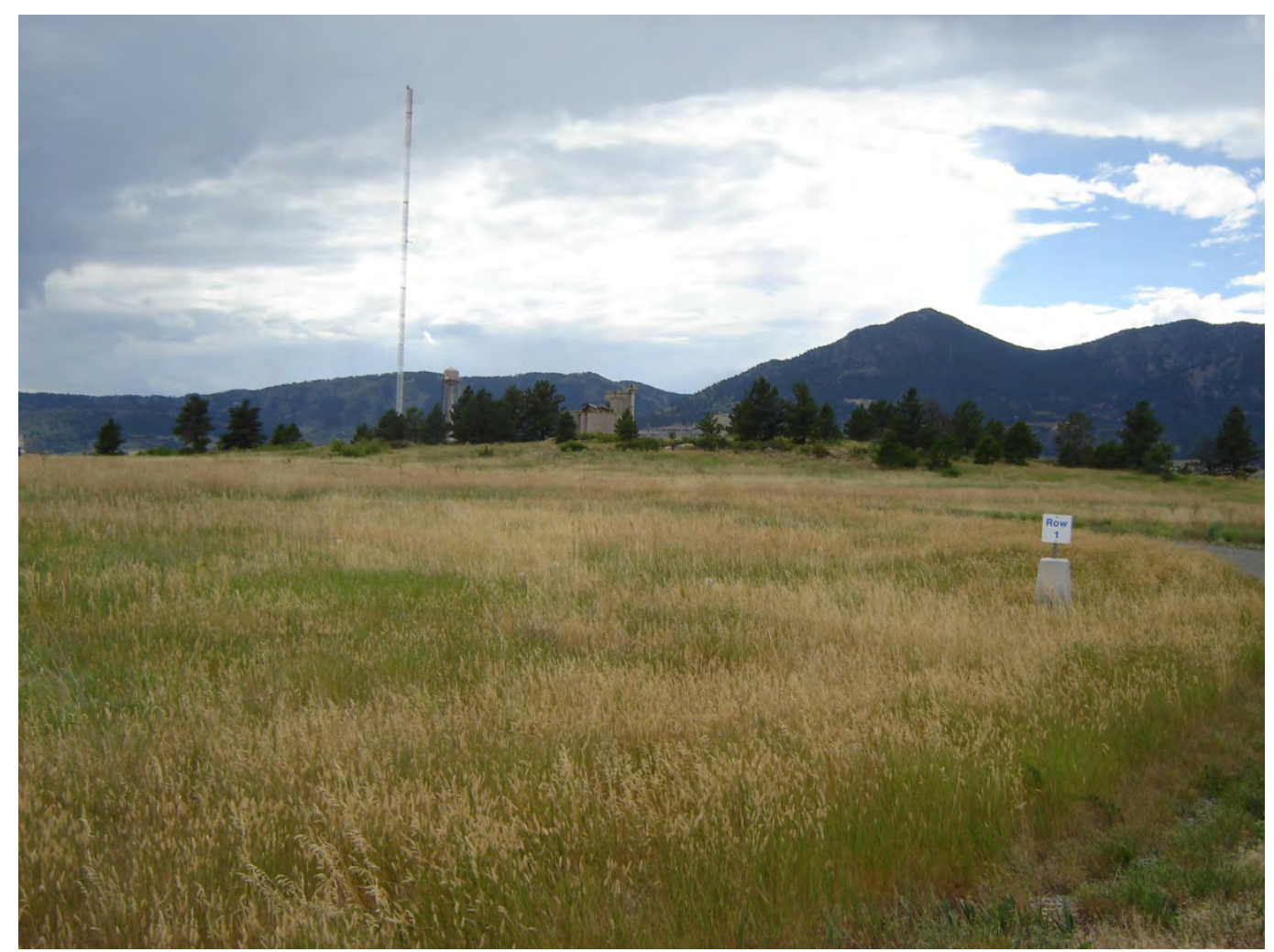

Photo 3. Looking southwest at the ponderosa pine woodland in the distance. August 5, 2010.

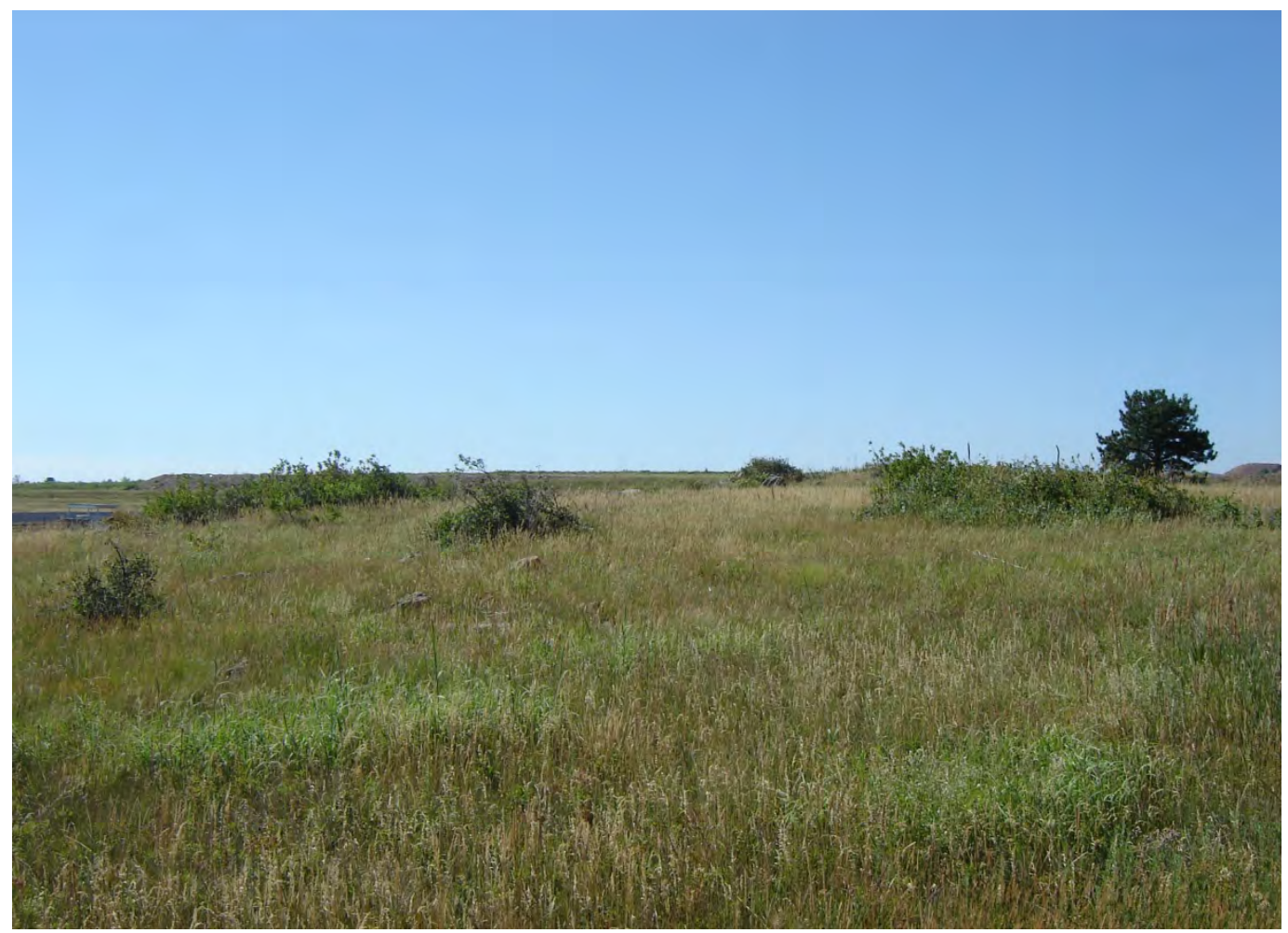

Photo 4. Looking south-southwest at the upland shrubland. August 5, 2010. 


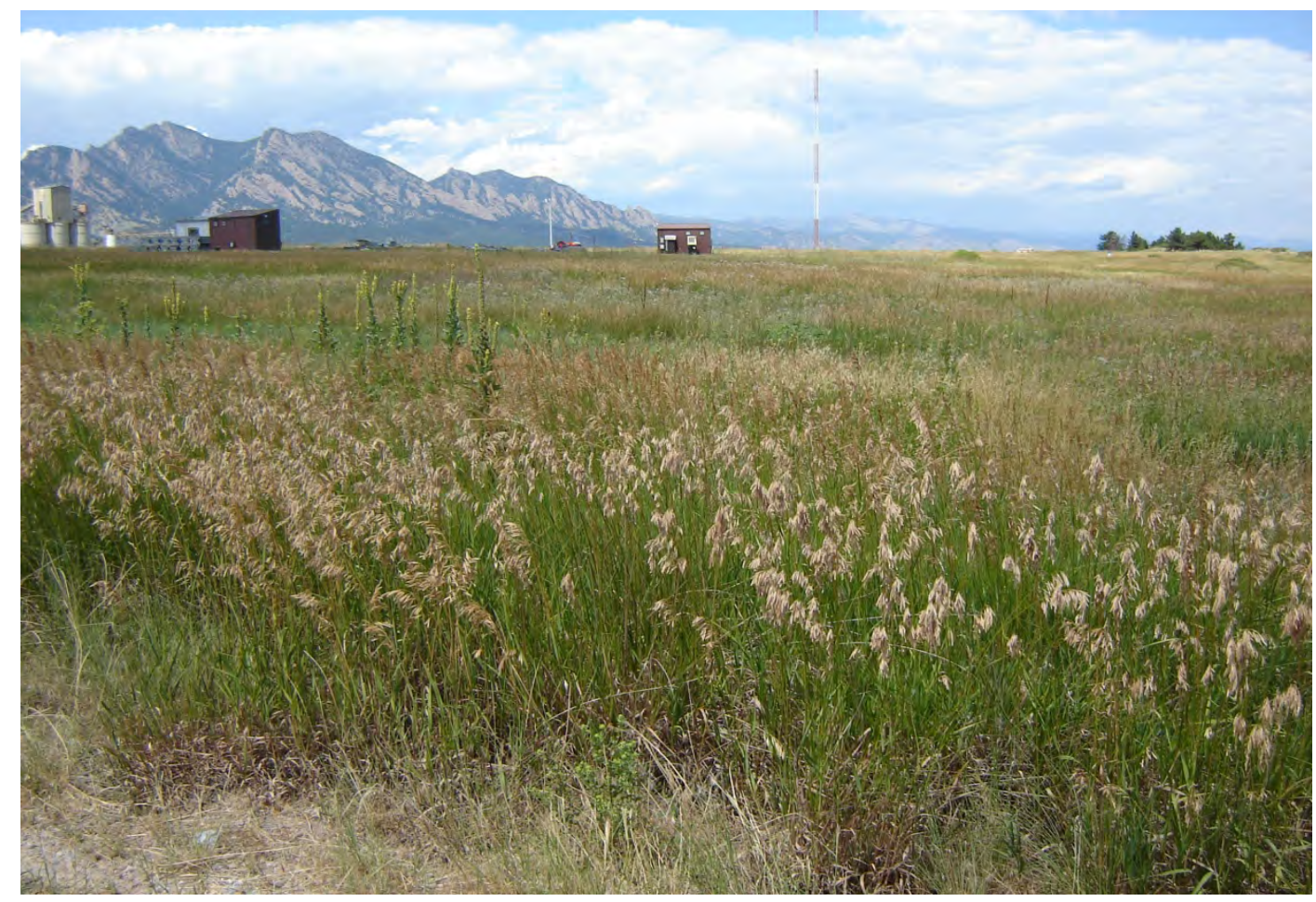

Photo 5. Looking northwest across PE-2. This area has experienced a general drying trend over the last decade. Dominants in this photo include smooth brome and mullein. Evidence of baltic rush can be found by combing through prior years' vegetation. Baltic rush can persist for years after a disturbance to it's water source. August 5, 2010.

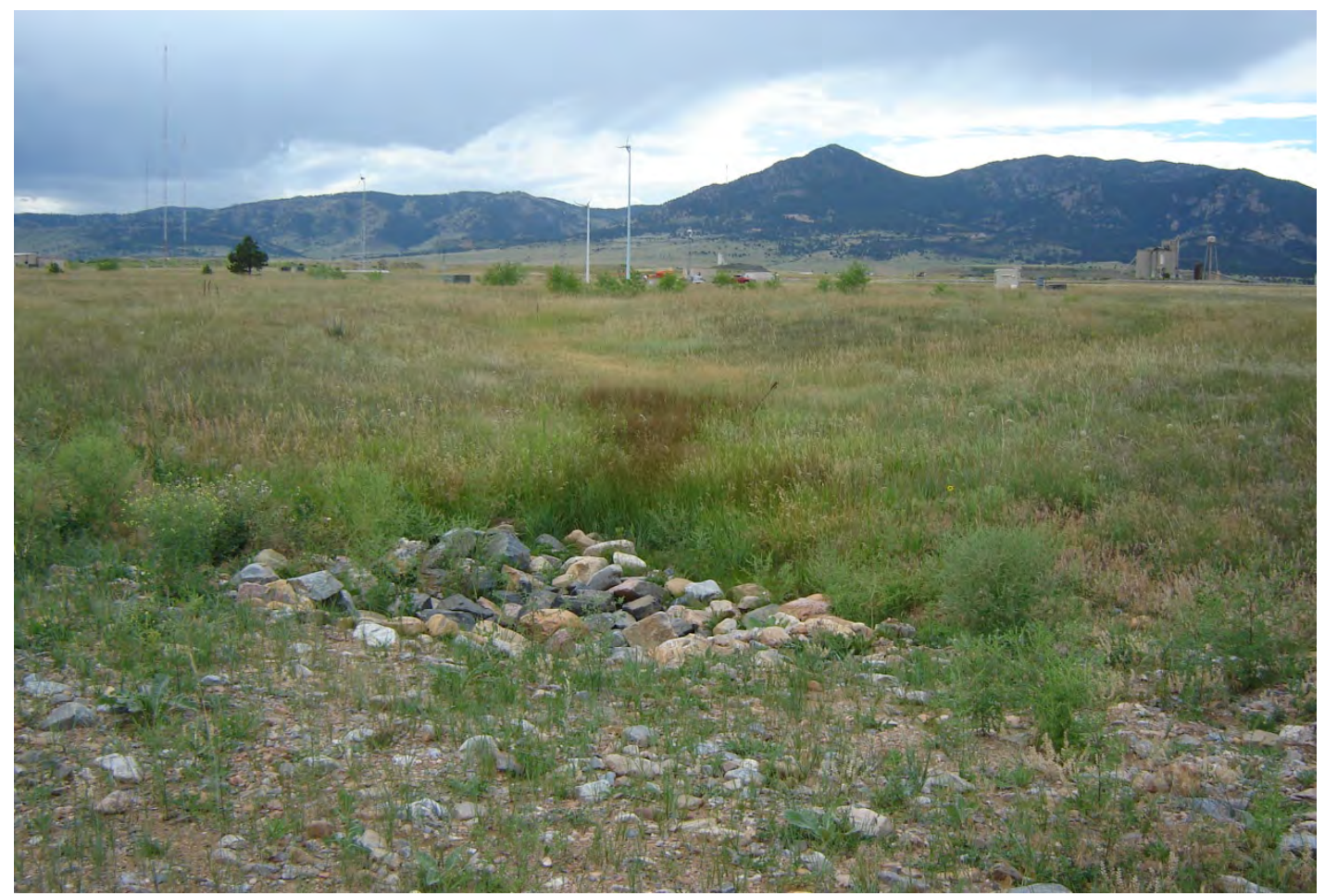

Photo 6. Looking west-northwest at the western end of RF-1 which consists of a shallow swale. August 5, 2010. 


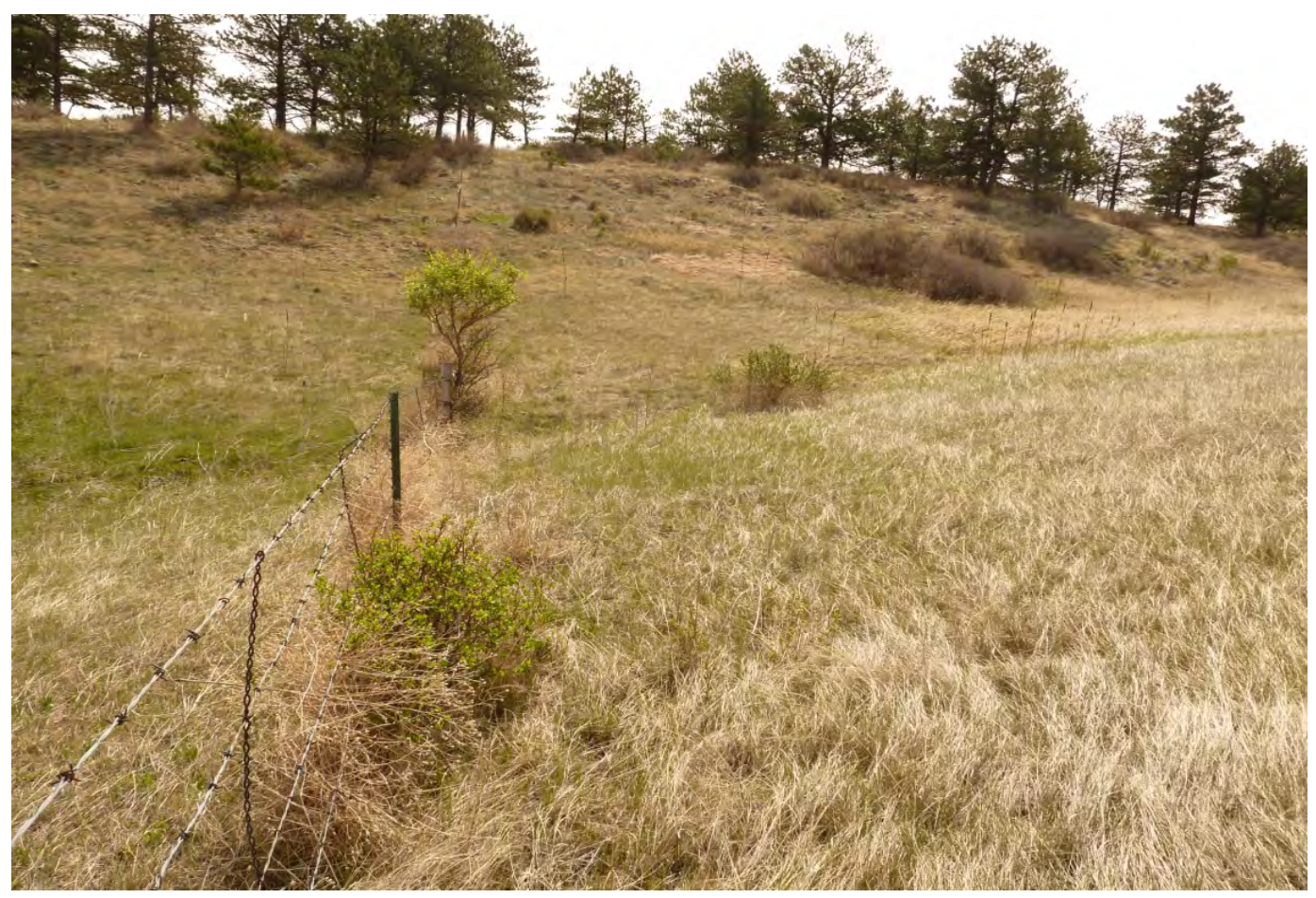

Photo 7. West of the ponderosa pine woodlands, looking east at the groundwater seep (GS-1) wetland in the distance. A hawthorn tree at it's south end grows along the property boundary fence. This area no longer supports cattails. May 9, 2011.

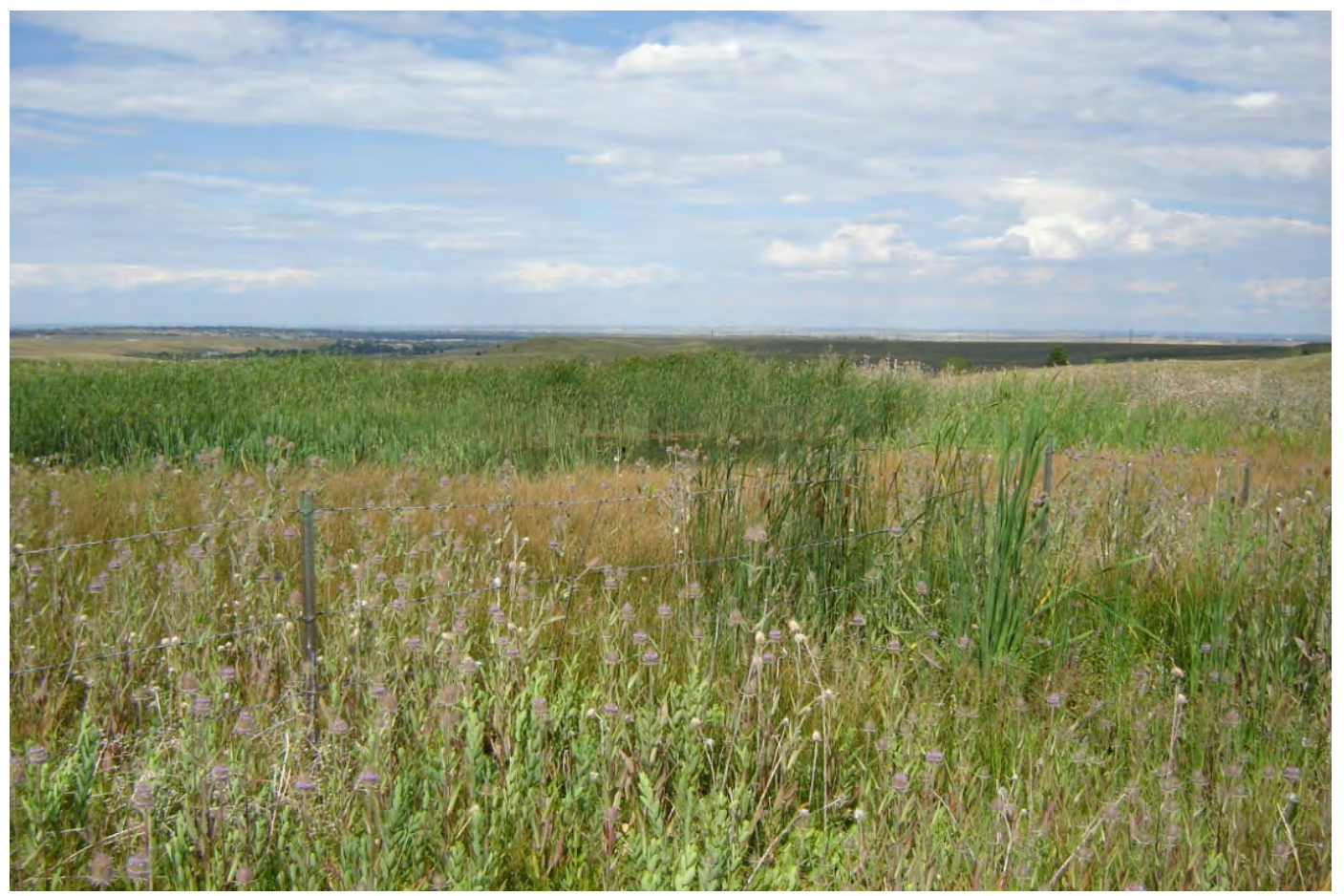

Photo 8. Looking at the northwest portion of the groundwater seep (GS-2) in the northeast portion of the site with common teasel in the foreground and cattails in the background. A pond beyond the northern site boundary is visible in the distance. August 5, 2010. 


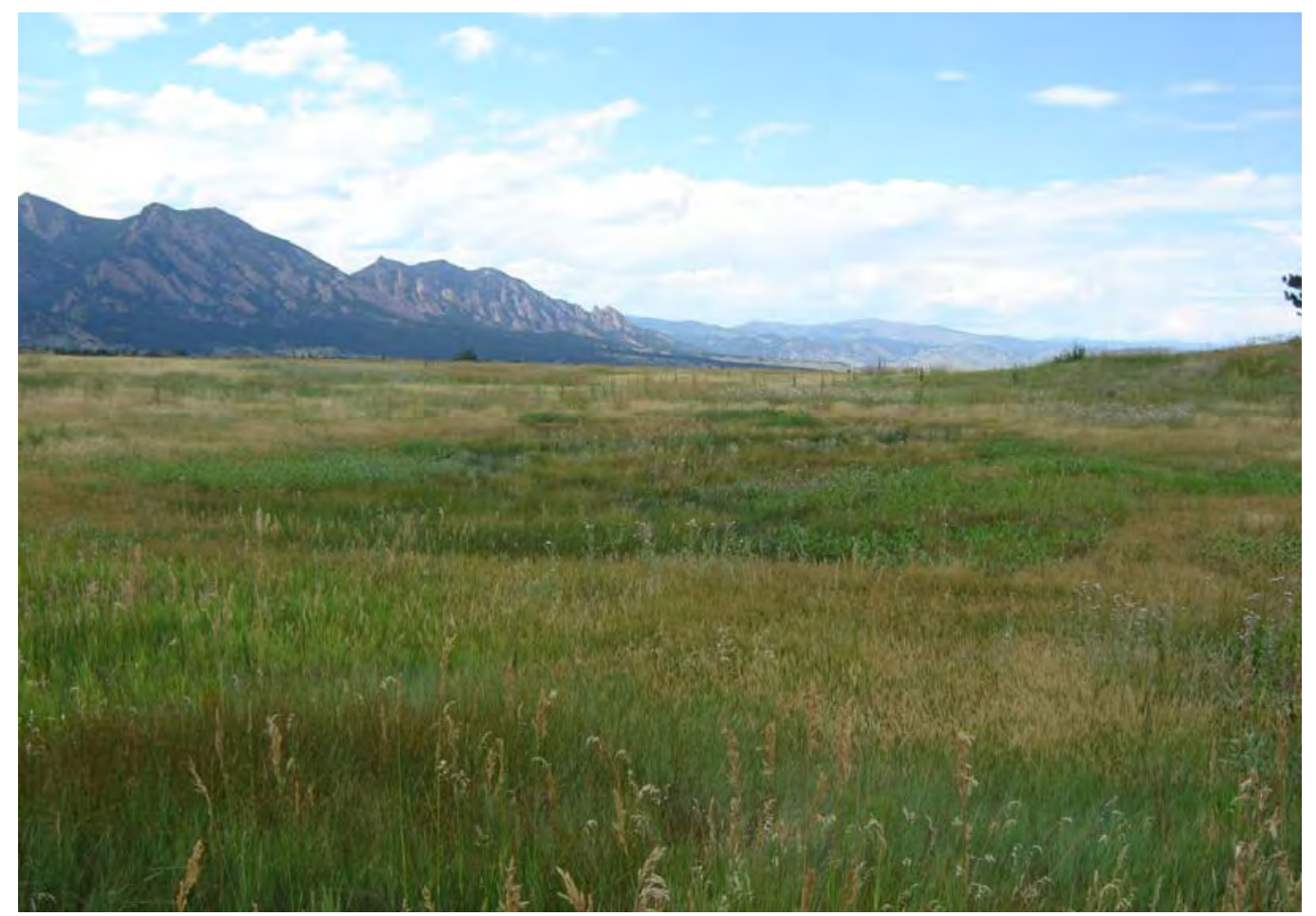

Photo 9. Looking northwest at the seasonal pond west of the ponderosa pine woodland. August 5, 2010.

\section{Other Photos}

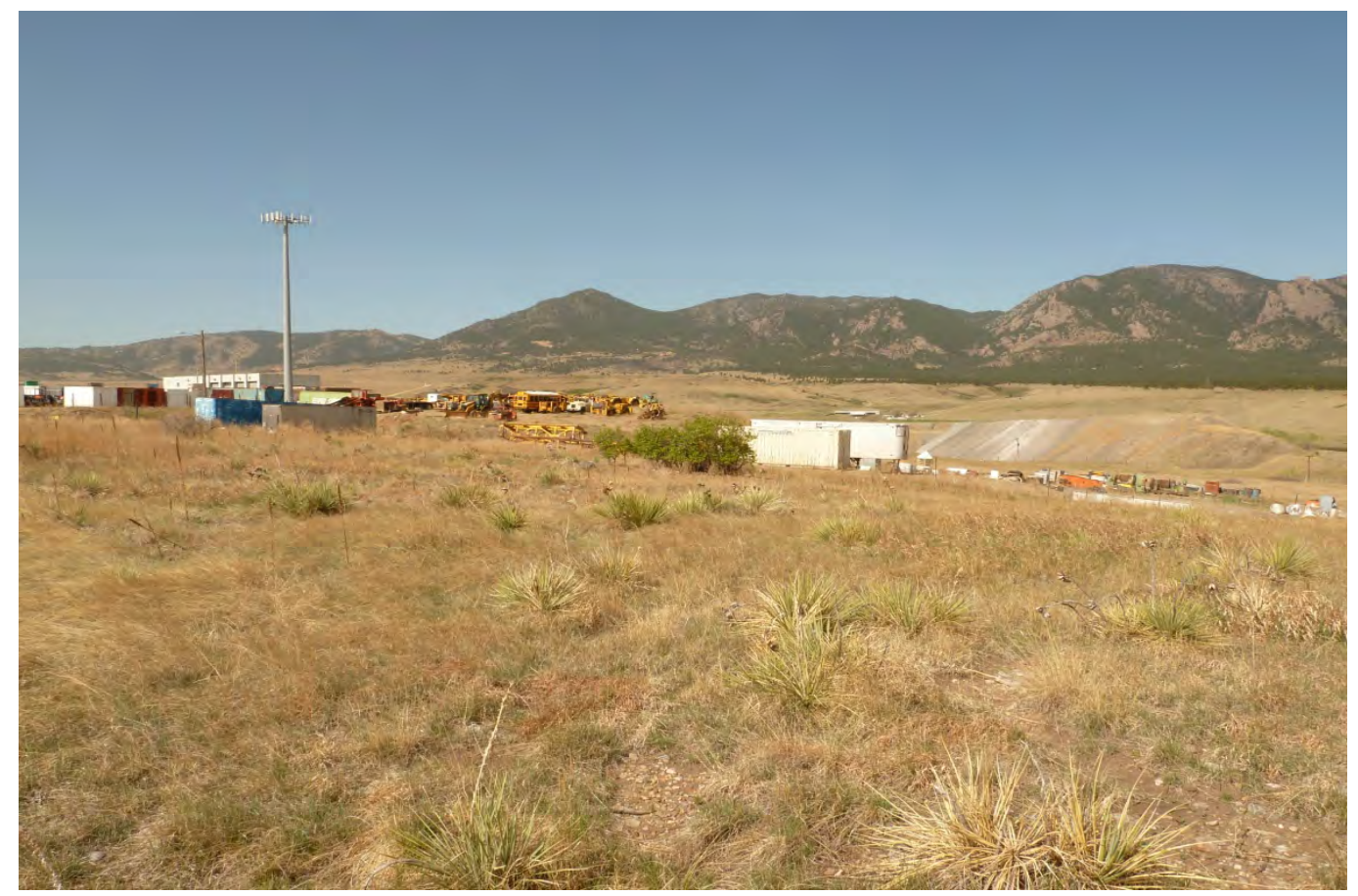

Photo 10. Looking southwest at an isolated group of hawthorn trees occurring along the western site boundary in the distance. May 9, 2011. 


\section{APPENDIX D}

Listing of Mammals, Reptiles, Amphibians, and Terrestrial Arthropods Observed During All Surveys Combined 
Appendix D. Listing of Mammals, Reptiles, Amphibians, and Terrestrial Arthropods Observed During All Surveys Combined, National Renewable Energy Laboratory National Wind Technology Center, $2010-2011$

\begin{tabular}{|c|c|c|}
\hline Common Name & Scientific Name & $\begin{array}{c}\text { Vegetation Community } \\
\text { Code* }\end{array}$ \\
\hline \multicolumn{3}{|c|}{ Mammals } \\
\hline $\begin{array}{l}\text { Thirteen-lined ground squirrel } \\
\text { (burrows only) }\end{array}$ & Spermophilus tridecemlineatus & XMG \\
\hline Deer Mouse & Peromyscus maniculatus & XMG, RFW, XMG/PPW \\
\hline Mexican Woodrat & Neotoma mexicana & XMG/PPW \\
\hline Prairie Vole & Microtus ochrogaster & RFW \\
\hline Meadow Vole & Microtus pennsylvanicus & RFW \\
\hline Western Harvest Mouse & Reithrodontomys megalotis & XMG \\
\hline Desert cottontail & Sylvilagus audubonii & BRS \\
\hline Masked Shrew & Sorex cinereus & RFW \\
\hline $\begin{array}{l}\text { Myotis bats }{ }^{\star \star} \text { (from acoustical } \\
\text { monitoring report, Appendix E) }\end{array}$ & Myotis sp. & XMG/PPW \\
\hline $\begin{array}{l}\text { Big brown bat (from acoustical } \\
\text { monitoring report, Appendix E) }\end{array}$ & Eptesicus fuscus & XMG/PPW \\
\hline $\begin{array}{l}\text { Fringed myotis (from acoustical } \\
\text { monitoring report, Appendix E) }\end{array}$ & Myotis thysanodes & XMG/PPW \\
\hline $\begin{array}{l}\text { Silver-haired bat (from acoustical } \\
\text { monitoring report, Appendix E) }\end{array}$ & Lasionycteris noctivagans & XMG/PPW \\
\hline $\begin{array}{l}\text { Hoary bat (from acoustical } \\
\text { monitoring report, Appendix E) }\end{array}$ & Lasiurus cinereus & XMG/PPW \\
\hline $\begin{array}{l}\text { Eastern red bat (from acoustical } \\
\text { monitoring report, Appendix E) }\end{array}$ & Lasiurus borealis & XMG/PPW \\
\hline Coyote (scat only) & Canis latrans & XMG \\
\hline American elk & Cervus canadensis & XMG \\
\hline Mule deer (beds) & Odocoileus hemionus & RFW \\
\hline \multicolumn{3}{|c|}{ Amphibians } \\
\hline Boreal chorus frog & Pseudacris maculata & RFW \\
\hline Woodhouse's toad (deceased) & Bufo woodhousii & XMG \\
\hline \multicolumn{3}{|c|}{ Reptiles } \\
\hline $\begin{array}{l}\text { Bull snake (observed on road } \\
\text { during orientation) }\end{array}$ & Pituophis catenifer & XMG \\
\hline \multicolumn{3}{|c|}{ Terrestrial Arthropods } \\
\hline Checkered white & Pontia protodice & RFW \\
\hline Western white & Pontia occidentalis & XMG \\
\hline Cabbage white & Pieris rapae & RFW \\
\hline
\end{tabular}




\begin{tabular}{|l|l|l|}
\hline \multicolumn{1}{|c|}{ Common Name } & \multicolumn{1}{|c|}{ Scientific Name } & \multicolumn{1}{c|}{$\begin{array}{c}\text { Vegetation Community } \\
\text { Code* }\end{array}$} \\
\hline Orange sulphur & Colias eurytheme & XMG \\
\hline Dainty sulphur & Nathalis iole & XMG \\
\hline Gray hairstreak & Strymon melinus & RFW \\
\hline Aphrodite fritillary & Speyeria aphrodite & RFW \\
\hline Common wood nymph & Cercyonis pegala & RFW \\
\hline
\end{tabular}

*Vegetation community code: $\mathrm{XMG}=$ Xeric mixed grassland, RFW=Riparian fringe wWetland, $\mathrm{PEW}=\mathrm{Palustrine}$ emergent wetland, BRS=Building/road/structure, $\mathrm{SP}=$ Seasonal pond, PPW=Ponderosa pine woodland.

**Included in this group may be one or more of the following species: western small-footed myotis, western longeared myotis, little brown myotis, and long-legged myotis. 


\section{APPENDIX E}

Bat Acoustical Surveys at the National Renewable Energy

Laboratory, National Wind Technology Center, Jefferson

County, Colorado, May 6, 2011 


\title{
Bat Acoustical Surveys at the National Renewable Energy Laboratory, National Wind Technology Center
}

\author{
Jefferson County, Colorado
}

May 5, 2011

Prepared for

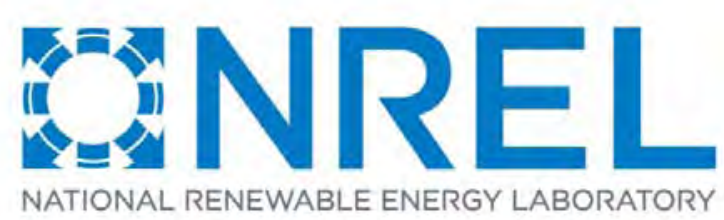

Prepared by

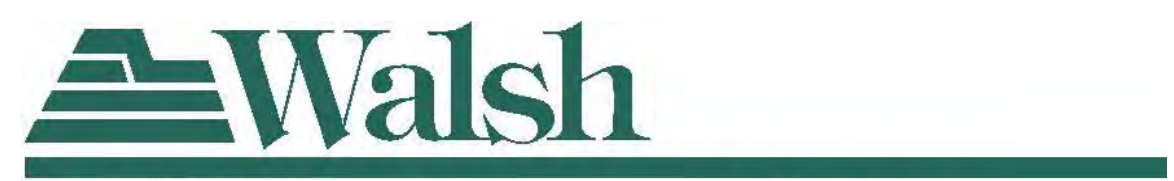

an ecology and environment company 


\section{TABLE OF CONTENTS}

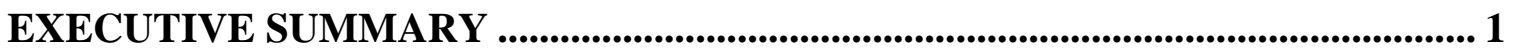

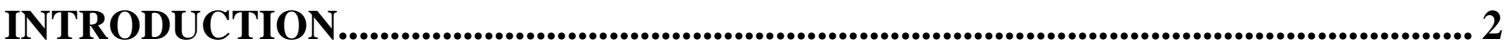

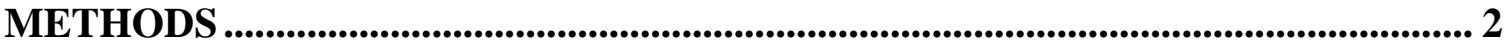

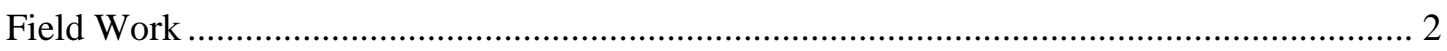

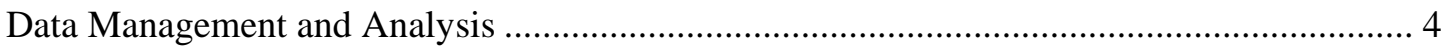

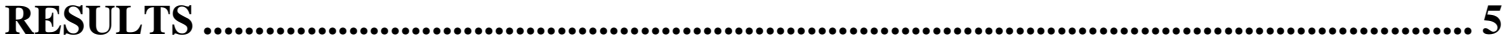

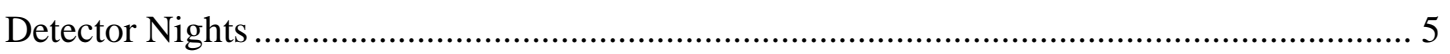

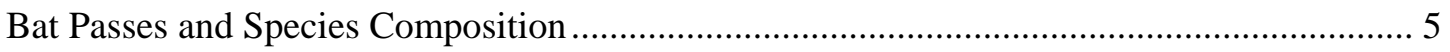

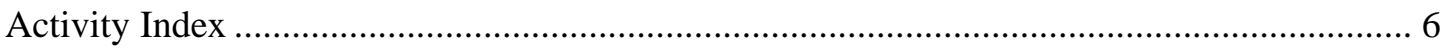

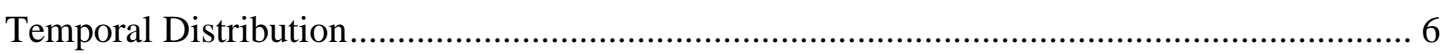

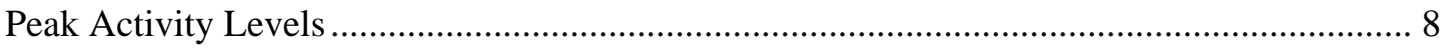

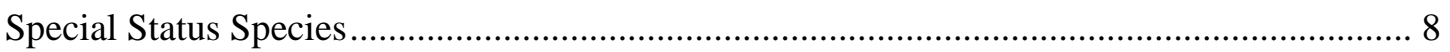

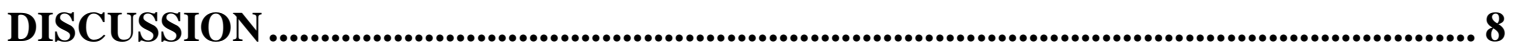

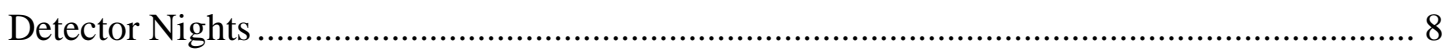

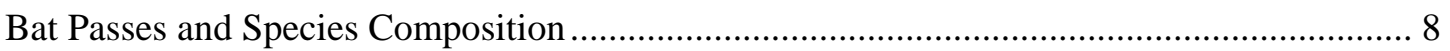

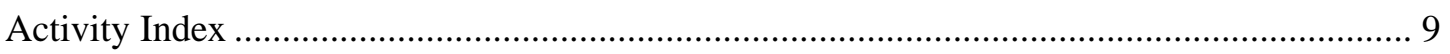

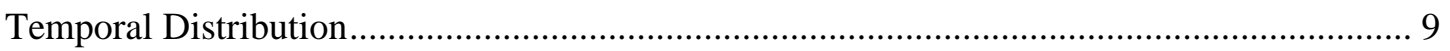

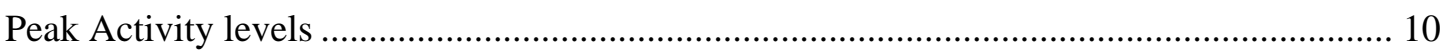

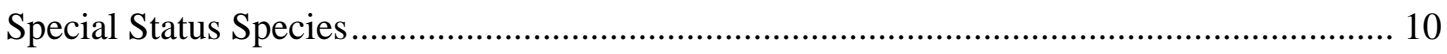

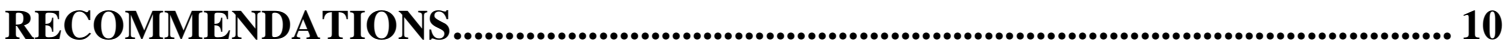

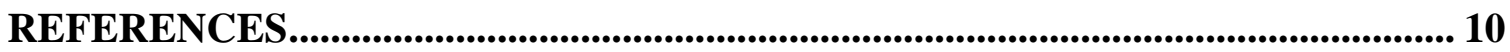




\section{TABLES}

Table 1. Detector Nights, NWTC, Jefferson County, Colorado 2010

Table 2. Identified Bat Passes and Index of Activity, NWTC, Jefferson County, Colorado 2010. 6

Table 3. Temporal Distribution of Bat Activity, NWTC, Jefferson County, Colorado 2010 ........ 7

Table 4. Baseline Bat Activity at NWTC Compared with Wind Energy Facilities.

\section{FIGURES}

Figure 1. AnaBat Detector Location, NWTC, Jefferson County, Colorado, 2010......................... 3

Figure 2. Bat Species Composition by Identified Bat Passes, NWTC, Jefferson County, Colorado 2010.

Figure 3. Index of Bat Activity by Month, NWTC, Jefferson County, Colorado 2010 ................. 7

Figure 4. Peak Activity Levels, by Total Bat Passes, NWTC, Jefferson County, Colorado, 2010. 8 


\section{LIST OF ACRONYMS}

CDOW Colorado Division of Wildlife

CF compact flash

NWTC

NREL's National Wind Technology Center

Mic microphone

Walsh

Walsh Environmental Scientists and Engineers 


\section{EXECUTIVE SUMMARY}

An acoustical bat use survey was conducted at the NWTC from July 6, 2010 to November 7, 2010, using a passive acoustical method with AnaBat Systems Bat Detectors (Titley Electronics). The purpose of this survey was to obtain information about use by bats within the Project area.

All data were collected from one bat detector was mounted on a fence post within the conservation easement in the northwest portion of the site. Bat activity was determined by the number of bat passes (number of echolocation calls recorded with $\geq 2$ chirps) per detector night. Species composition, temporal distribution (by month), and peak activity levels were analyzed.

A total of 12,425 bat passes was recorded during the survey period for an index of activity of 99.40 bat passes per detector night. Of the 12,425 total bat passes, 8,772 passes could be identified to species (70.18 identified bat passes per detector night).

Species identified included big brown bat, eastern red bat, fringed myotis, hoary bat, silver-haired bat, and Myotis bat group (which may include western small-footed myotis, western long-eared myotis, little brown myotis, and long-legged myotis).

Most bats were detected in July (3,952 total bat passes) and August (5,058 total bat passes). The Myotis bat group was most the most frequently detected (4,373 identified bat passes).

There were no peaks of activity during the monitoring period, but rather constant fluctuation.

No Federally- or state-listed threatened, endangered, or candidate species or species of special concern were identified during surveys (USFWS 2010, CDOW 2010). 


\section{INTRODUCTION}

Walsh Environmental Scientists and Engineers, LLC (Walsh) was retained by the National Renewable Energy Laboratory (NREL) to conduct acoustic bat surveys at the National Wind Technology Center (NWTC). This effort involved using passive acoustical detectors that recorded bat echolocation calls from July to November 2010. This report presents the results of these surveys.

NWTC is located on approximately 320 acres in Jefferson County, Colorado, on State Highway 128 between the cities of Boulder and Golden, Colorado adjacent to the eastern foothills of the Rocky Mountains. The legal description of the current boundary is: T2N, R70W, portions of Sections 3 and 4.

The site is largely composed of Xeric mixed grassland. The bat monitoring unit was located in a draw within a conservation easement in the western portion of the site. There is a small stand of ponderosa pines directly east of the unit, a small ephemeral pond a few hundred yards south, and a larger, long-lasting pond one-half mile south (Figure 1).

\section{METHODS}

\section{Field Work}

Bat echolocation calls were recorded from July 6 to November 7, 2010, using an AnaBat SD2 ultrasonic detector from Titley Electronics, Ballina, Australia. One AnaBat detector was installed on a fencepost within the conservation easement at roughly 0.5 meters above the ground. It is recognized that attenuation of bat calls occurs at roughly 30 meters from the unit, indicating that the detector was able to capture calls about 30 meters above the ground.

Data collection methods followed Kunz et al. (2007). Call recording was conducted during crepuscular and nocturnal hours (about one hour before sunset to one hour after sunrise) to capture peak times of bat activity (Reynolds 2006). All files recorded during the survey period were saved to 1 gigabyte compact flash (CF) cards that were collected at two- to three-week intervals and downloaded to a computer using Titley's CF card reader software. 


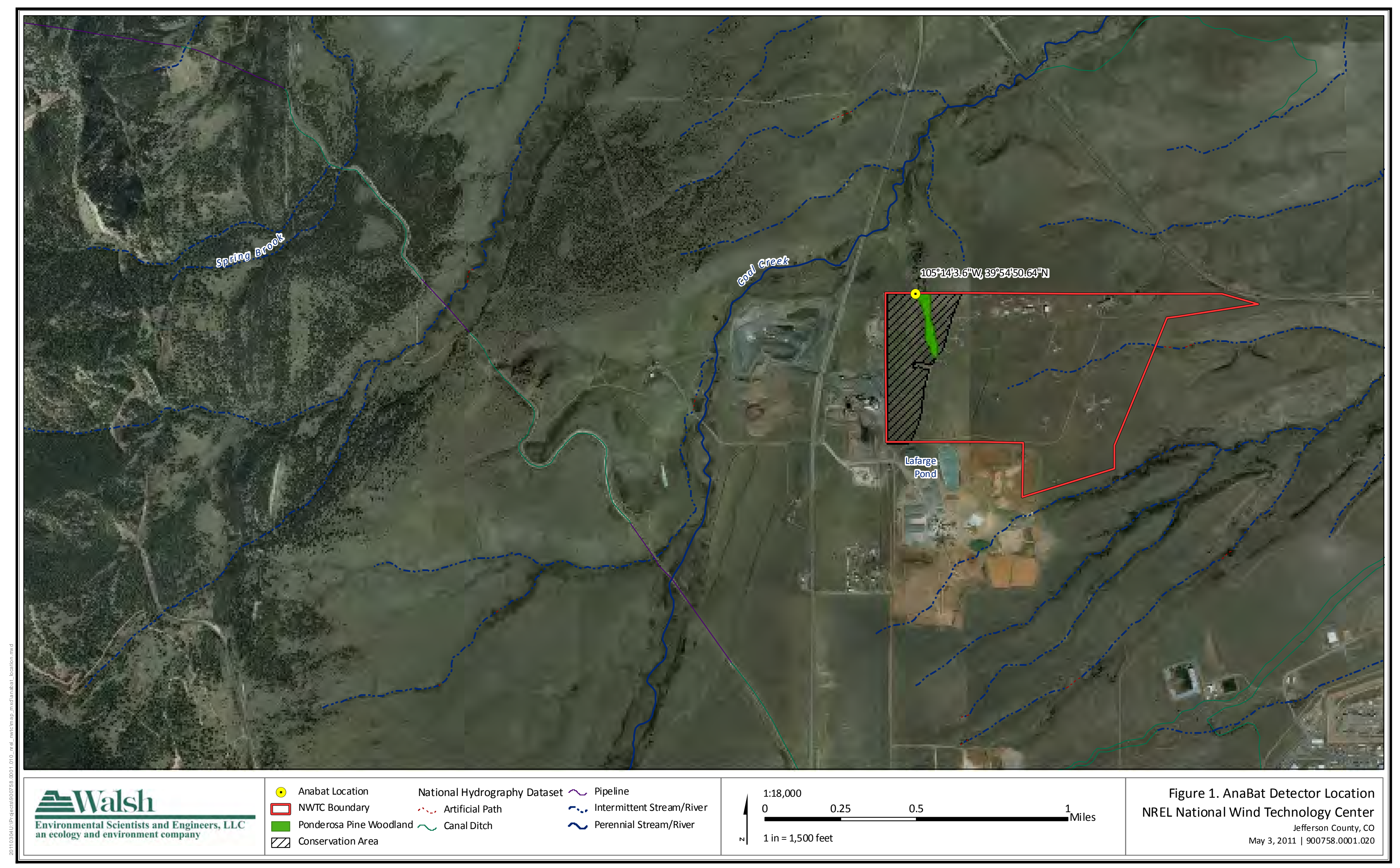




\section{Data Management and Analysis}

Data gathered from the AnaBat detector were analyzed using Analook software. A preliminary analysis was run to separate extraneous noise files (which may include noise created by weather, radio or microwaves, insects, birds, etc.) from bat echolocation call files. The number of bat calls could then be determined and reported using the metric "bat pass." A bat pass is an accepted measure of bat activity defined as an echolocation sequence of at least two echolocations pulses, or chirps, with a minimum pulse duration of 10 milliseconds within each sequence, separated by more than one second (Gannon et al. 2003, Kunz et al. 2007). Bat call files were further identified and segregated into species groups to show species composition of bats on the site. A number of calculated variables are derived from the bat pass data and are described below.

Bat passes were identified to species or species group when possible, and this subset of bat passes is termed "identified bat pass." Identified bat passes included all bat passes that had five or more clear echolocation calls, or chirps. Myotis bats are a group whose individual species' calls are difficult to distinguish. These calls are therefore lumped as Myotis bats, and may include one or more of the following species known to occur along the Front Range of Colorado: western smallfooted myotis (Myotis ciliolabrum), western long-eared myotis (Myotis evotis), little brown myotis (Myotis lucifugus), and long-legged myotis (Myotis volans). The fringed myotis (Myotis thysanodes) is an exception as its calls are distinct.

An index of relative bat activity, or activity index, was calculated as the number of bat passes per detector night (the number of nights the detector was recording data). Additionally, an activity index was determined per species by using the number of identified bat passes for each species per detector night. Other metrics calculated from the data include temporal distribution of bat activity by month and peak activity.

Two important assumptions are required for these data analyses that may not be completely supported:

1) Each bat pass accounts for a single bat recorded only once by the AnaBat detector. One bat pass may actually contain more than one individual bat echolocating, or alternatively, multiple bat passes may be the same bat circling around and echolocating. However, recognition of individuals cannot be determined using AnaBat detectors, so the analysis must be conducted with one bat pass equivalent to one bat.

2) All species are equally well detected by AnaBat detectors. Different species of bats echolocation calls attenuate at differing distances, with some species of bats whose calls attenuate at shorter distances being recorded less often than those whose calls carry further. For example, Townsend's big-eared bat (Corynorhinus townsendii) has a weak call that attenuates quickly and is not as readily detected as many other species (Piaggio 2005). Furthermore, behavioral differences may result in certain species being recorded more often than others. Since there is no appropriate way to correct for these differences, detection equality must be assumed (Gannon et al. 2003).

During data analysis, any special status species, i.e., Federally- or state-listed threatened, endangered, or candidate species, or species of special concern were noted (USFWS 2010, CDOW 2010). 


\section{RESULTS}

\section{Detector Nights}

One AnaBat detector recorded data for 125 detector nights, every night from July 6 to November 7, 2010 (Table 1).

Table 1. Detector Nights, NWTC, Jefferson County, Colorado 2010.

\begin{tabular}{|l|c|}
\hline Month & Detector Nights \\
\hline July & 26 \\
\hline August & 31 \\
\hline September & 30 \\
\hline October & 31 \\
\hline November & 7 \\
\hline Total & $\mathbf{1 2 5}$ \\
\hline
\end{tabular}

\section{Bat Passes and Species Composition}

A total of 12,425 bat passes were recorded during the survey period. Of those, 8,772 were identified to species. Species composition is summarized in Figure 2 and included 50 percent Myotis bats (Myotis sp.) (4,373 identified bat passes), 36 percent big brown bat (Eptesicus fuscus) (3,145 passes), 7 percent fringed myotis (592 passes) (Myotis thysanodes), 5 percent silver-haired bat (Lasionycteris noctivagans) (481 passes), 2 percent hoary bat (Lasiurus cinereus) (179 passes), and less than 1 percent eastern red bat (Lasiurus borealis) (2 passes).

\section{Figure 2. Bat Species Composition by Identified Bat Passes, NWTC,} Jefferson County, Colorado 2010.

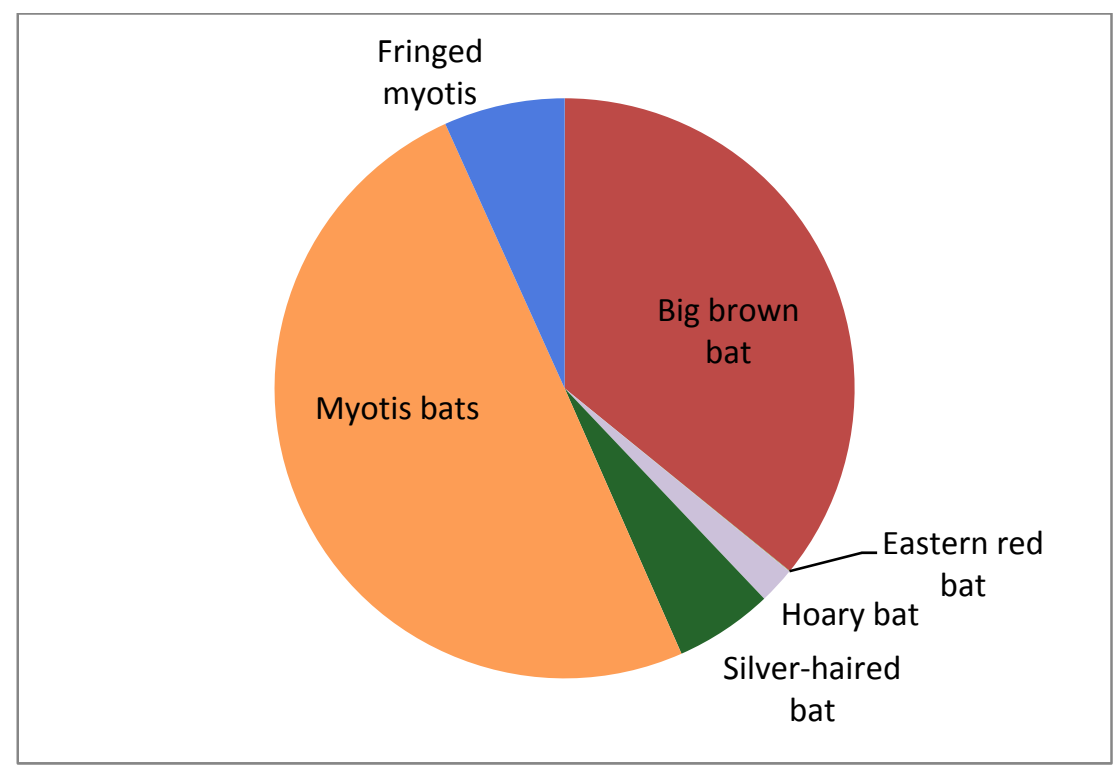




\section{Activity Index}

There are two indices of bat activity: total bat passes, which includes all echolocation calls with two or more chirps, and identified bat passes, which is limited to those with five or more chirps (see Methods). The overall activity index recorded at the AnaBat detector was 99.40 total bat passes per detector night and 70.18 identified bat passes per detector night (Table 1). The species of bat with the highest activity index is the Myotis bat group (34.98 bat passes per detector night). Big brown bat also had comparatively high levels of activity (25.15 bat passes per detector night). Fringed myotis, silver-haired bat, and hoary bat had comparatively moderate levels of activity, between 1.43 to 4.74 identified bat passes per detector night. Eastern red bat had a comparatively low level of activity (0.02 identified bat passes per detector night) (Table 2).

Table 2. Identified Bat Passes and Index of Activity, NWTC, Jefferson County, Colorado 2010.

\begin{tabular}{|l|c|c|c|}
\hline \multicolumn{1}{|c|}{ Common Name } & Scientific Name & $\begin{array}{c}\text { Number } \\
\text { Identified }\end{array}$ & $\begin{array}{c}\text { Index of Activity (Number } \\
\text { Identified/Detector Nights) }\end{array}$ \\
\hline Myotis bats* & Myotis sp. & 4,373 & 34.98 \\
\hline Big brown bat & Eptesicus fuscus & 3,145 & 25.15 \\
\hline Fringed myotis & Myotis thysanodes & 592 & 4.74 \\
\hline Silver-haired bat & $\begin{array}{c}\text { Lasionycteris } \\
\text { noctivagans }\end{array}$ & 481 & 3.85 \\
\hline Hoary bat & Lasiurus cinereus & 179 & $\mathbf{1 . 4 3}$ \\
\hline Eastern red bat & Lasiurus borealis & 2 & 0.02 \\
\hline Total Identified Bat Passes & & $\mathbf{8 , 7 7 2}$ & $\mathbf{7 0 . 1 8}$ \\
\hline Total Bat Passes & & $\mathbf{1 2 , 4 2 5}$ & $\mathbf{9 9 . 4 0}$ \\
\hline
\end{tabular}

*Included in this group may be one or more of the following species: western small-footed myotis, western long-eared myotis, little brown myotis, and long-legged myotis.

\section{Temporal Distribution}

Total bat activity was highest in July (3,952 bat passes) and August (5,058 bat passes) with an activity index of 152.04 and 163.16 total bat passes per detector night, respectively. September was also a month of high bat activity (3,221 bat passes) with an activity indices of 107.37 total bat passes per detector night. October and November had relatively low levels of bat activity (190 and 3 bat passes) with activity indices of 6.13 and 0.43 total bat passes per detector night, respectively (Figure 3, Table 3). 
Figure 3. Index of Bat Activity by Month, NWTC, Jefferson County, Colorado 2010.

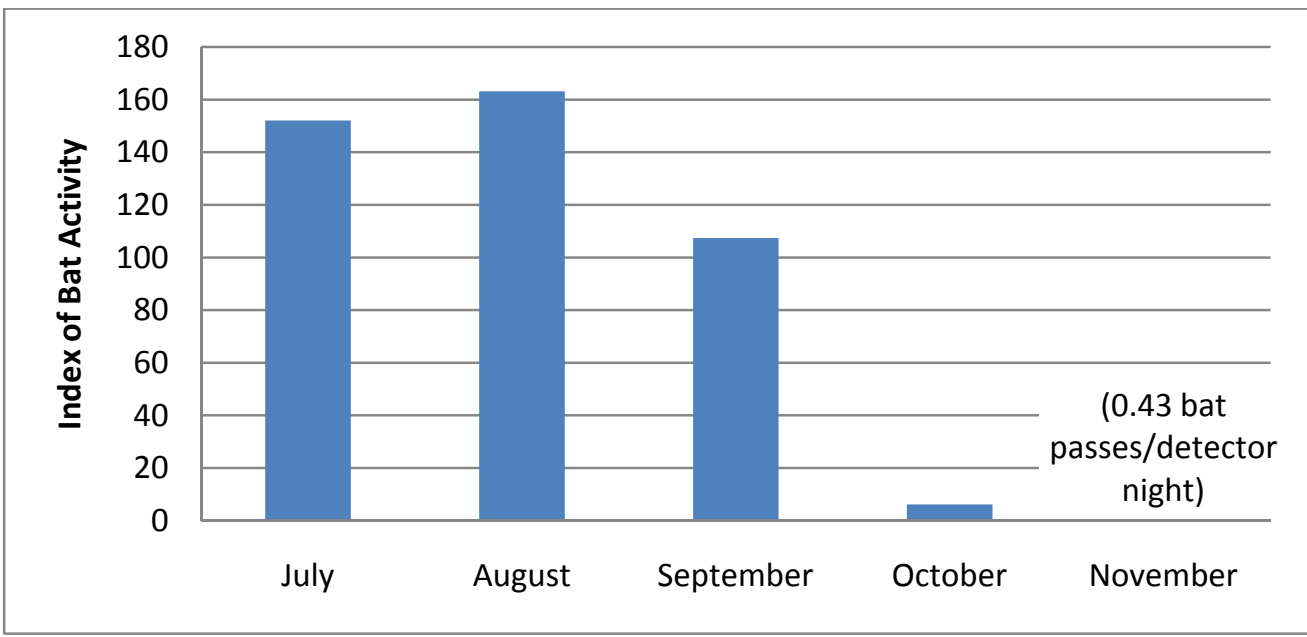

Note: Index of bat activity is determined by number of bat passes per detector night for that month; detector nights are shown in Table 1.

Identified bat passes were also highest in July (3162) and August (3,299 bat passes) with an activity index of 121.62 and 106.42 identified bat passes per detector night, respectively. Bat activity was moderate in September, lower in October, and very low in November.

Big brown bats, Myotis bats, and hoary bats experienced their highest activity in July and August (Table 3), with hoary bats active at much lower frequencies than the other two species/groups. Fringed myotis were active in July, August and September; silver-haired bats were most active in September but maintained a presence in July and August as well. Eastern red bats had very low activity, though were present in July and August.

Table 3. Temporal Distribution of Bat Activity, NWTC, Jefferson County, Colorado 2010.

\begin{tabular}{|l|c|c|c|c|c|}
\hline Species & July & Aug & Sept & Oct & Nov \\
\hline Big brown bat & 58.15 & 39.97 & 12.37 & 0.68 & 0.14 \\
\hline Eastern red bat & 0.04 & 0.03 & 0.00 & 0.00 & 0.00 \\
\hline Fringed myotis & 6.38 & 6.74 & 7.13 & 0.10 & 0.00 \\
\hline Hoary bat & 2.53 & 3.03 & 0.63 & 0.00 & 0.00 \\
\hline Myotis bats & 51.19 & 52.06 & 46.13 & 1.42 & 0.00 \\
\hline Silver-haired bat & 3.31 & 4.55 & 6.37 & 1.97 & 0.29 \\
\hline $\begin{array}{l}\text { Total Identified Bat } \\
\text { Passes }\end{array}$ & $\mathbf{1 2 1 . 6 2}$ & $\mathbf{1 0 6 . 4 1}$ & $\mathbf{7 2 . 6 3}$ & $\mathbf{4 . 1 6}$ & $\mathbf{0 . 4 3}$ \\
\hline Total Bat Passes & $\mathbf{1 5 2 . 0 4}$ & $\mathbf{1 6 3 . 1 6}$ & $\mathbf{1 0 7 . 1 6}$ & $\mathbf{6 . 1 3}$ & $\mathbf{0 . 4 3}$ \\
\hline
\end{tabular}

Note: Bat activity determined by number of identified bat passes per detector night for that month. 


\section{Peak Activity Levels}

The level of bat activity fluctuates consistently from the beginning of monitoring in July through the end of September, when levels drop off (Figure 4). Although there are no true peaks of activity, which would be indicated by a fairly steady rise to a high point in activity, there are several spikes in activity that can be seen on July 21 (315 bat passes), August 18 (390 bat passes), August 26 (370 bat passes), August 28 (309 bat passes) and September16 (322 bat passes).

\section{Figure 4. Peak Activity Levels, by Total Bat Passes, NWTC, Jefferson County, Colorado, 2010}

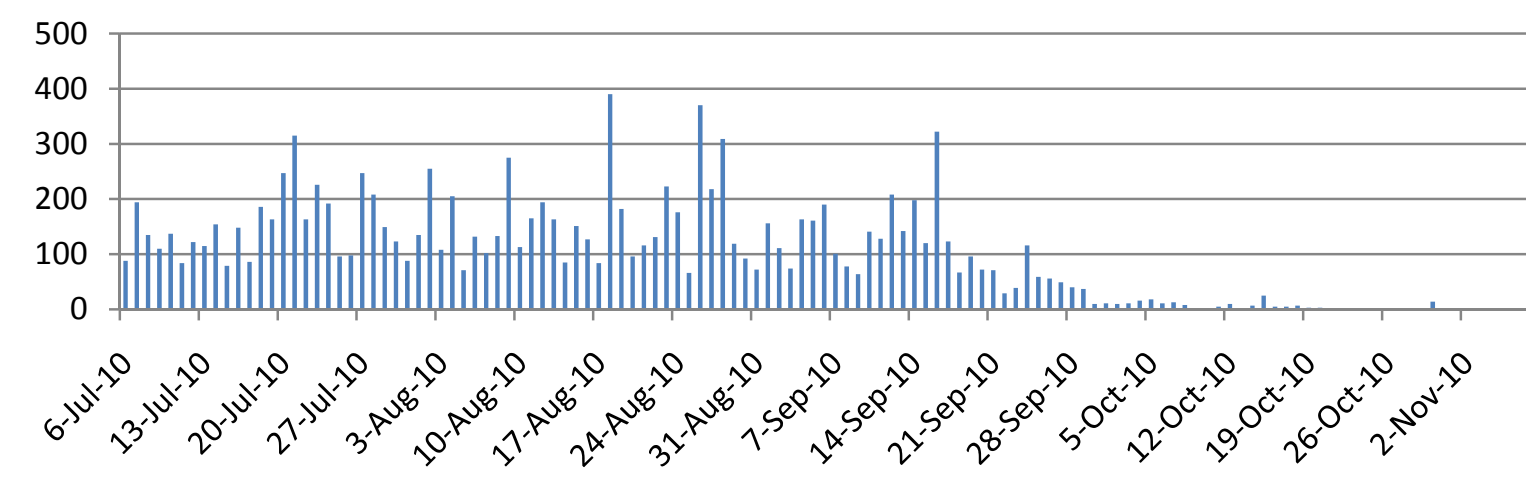

\section{Special Status Species}

No Federally-listed threatened, endangered or candidate bat species listed by the Endangered Species Act are known to occur in Colorado (USFWS 2010). No state-listed threatened or endangered species or species of special concern were identified during surveys (CDOW 2010).

\section{DISCUSSION}

\section{Detector Nights}

The AnaBat detector ran every night without obvious problems from July 6, 2010 to November 7, 2010.

\section{Bat Passes and Species Composition}

The Myotis bat group was the most commonly detected group during monitoring with 4,373 identified bat passes, or nearly half of all identified bats. Since it is very difficult to differentiate echolocation calls of the species in this group, they were not identified to species. The species of Myotis that are known to inhabit this region include western small-footed myotis, western longeared myotis, little brown myotis, and long-legged myotis. The Myotis group may be made up of any of these species. Since this group was detected throughout July, August, and September, they are most likely resident bats. Big brown bats were the second most commonly detected group with 3,144 identified bat passes. Their presence throughout July, August, and September also shows that they are most likely resident bats.

Of the 18 species of bats documented in Colorado (Armstrong et al. 1994; Fitzgerald et al. 1994), a minimum of 6 species and up to 9 species were identified on site (depending on how many Myotis species are present in the Myotis bat group). Several calls recorded may have been pallid bat calls (Antrozous pallidus), but due to the unlikely event that this species would occur along 
the foothills, and that aspects of pallid bat calls look very similar to either big brown bats or little brown myotis, these calls were not identified as pallid bats. Although Colorado bat populations and distribution have not been thoroughly studied, these results are consistent with what is generally known about the bat populations within the state (Adams 2003, Armstrong et al. 1994).

\section{Activity Index}

Total bat passes for the survey period was 99.40 per detector night. Although data may not be perfectly comparable with monitoring done at wind farms, this level of activity is much higher than what has been found for projects in this and other regions of the U.S (Table 4). It is not known why the levels of activity on this site are so high. Several hypotheses include:

1) The Ponderosa pines, shrubs, and grasses in the draw where the AnaBat unit was located provide good foraging for bats, as well as potential roosting sites in the trees;

2) The large pond on the Lafarge mining property (Spicer) 0.5 mile to the south of the AnaBat unit is the best quality and closest water source to bat roosts, and this water source is available through the summer, when smaller water sources will become dry;

3) The rocky ridgeline of the foothills, roughly two miles to the west, provides good roosting habitat, a limiting factor for bats; and

4) Vacant buildings on Lafarge's property may provide good roosting habitat for big and little brown bats.

\section{Table 4. Baseline Bat Activity at NWTC Compared with Wind Energy Facilities.}

\begin{tabular}{|l|l|l|}
\hline \multicolumn{1}{|c|}{ Wind Energy Facility } & \multicolumn{1}{|c|}{$\begin{array}{c}\text { Bat Activity } \\
\text { (total bat passes/detector } \\
\text { night) }\end{array}$} & \multicolumn{1}{|c|}{ Reference } \\
\hline Colorado Highlands, CO & 0.23 & Walsh 2010 \\
\hline Top of the World, WY & 0.58 & Rintz and Kimberly 2009 \\
\hline Dunlap Ranch, WY & 1.67 & Johnson et al. 2009 \\
\hline Campbell Hill, WY & 2.03 & Taylor et al. 2008 \\
\hline Buffalo Mountain, TN & 23.70 & Fiedler 2004 \\
\hline Mountaineer, WV & 38.30 & Arnett et al. 2005 \\
\hline NWTC, CO & 99.40 & This report \\
\hline
\end{tabular}

\section{Temporal Distribution}

For all species combined, the highest number of bat passes was recorded in July and August. This suggests that the majority of recorded bat passes are from local, resident bats. Bat passes recorded in late August, September, and October may be related to fall migration. This coincides with other studies that have found high levels of bat activity in the late summer and early fall (Erickson et al. 2002, Cryan 2003, Kunz et al. 2007). 
Big brown bats appear to be resident, as they are most active in July and August. Myotis bats, active July through September on site, may delay migration until later in September. Fringed myotis is also likely resident, with activity from July through September and their known presence in the general vicinity (Rick Adams, personal communication, March 11, 2011). Silverhaired bats show some resident activity with a presence in July and August; the higher activity in September is indicative of their migratory behavior. Hoary bats are solitary and seldom abundant, suitably reflected in their low abundance in July and August. The eastern red bat was present in July and August but very infrequently and is uncommon in Colorado.

\section{Peak Activity levels}

Bat activity fluctuated from July to September and then decreased until the end of the monitoring period with no true peaks of activity. This, again, suggests that most of the bat activity captured during the summer was of resident bats. The fluctuation of activity levels, as well as the spikes of activity, may be due to weather or other factors that influence the activity of bats.

\section{Special Status Species}

No special status species were identified during acoustical bat surveys. Townsend's big-eared bat, the only state-listed bat species, is known to occur near this area (Adams 2003). Maternity colonies have been identified and are protected at Harmon and Mallory caves on City of Boulder Open Space and Mountain Parks land roughly 5 miles to the north/northwest (http://www.bouldercolorado.gov/files/openspace/closure documents/MalloryHarmonCave Whit eNoseSyndrome.pdf).

\section{RECOMMENDATIONS}

Walsh recommends several additional surveys which will help to better understand bat movement and activity at NWTC.

- Continued passive acoustical monitoring of bats from April 1 to July 6 to complete a full year of monitoring.

- Continued monitoring in subsequent years to substantiate patterns seen in this study as well as provide year-to-year comparisons.

- Additional passive acoustical monitoring at different locations and heights to see the movement of bats through the site

- Mist netting surveys can better identify which species are using the site

- Putting radio-tags on some bats can show where they are roosting.

\section{REFERENCES}

Adams, R.A. 2003. Bats of the Rocky Mountain West: natural history, ecology, and conservation. University Press of Colorado, Boulder.

Armstrong, D.M., R.A. Adams, K.W. Navo, J. Freeman, and S.J. Bissell. 1994. Bats of Colorado: Shadows of the Night. Colorado Division of Wildlife, Denver, Colorado. 
Arnett, E.B., W.P. Erickson, J. Kerns, and J. Horn. 2005. Relationships between Bats and Wind Turbines in Pennsylvania and West Virginia: An Assessment of Fatality Search Protocols, Patterns of Fatality, and Behavioral Interactions with Wind Turbines. Prepared for the Bats and Wind Energy Cooperative.

Colorado Division of Wildlife (CDOW). 2010. Colorado Endangered, Threatened and Species of Special Concern.

http://wildlife.state.co.us/WildlifeSpecies/SpeciesOfConcern/Mammals/MammalsOfCon cern.htm

Cryan, P.M. 2003. Seasonal distribution of migratory tree bats (Lasiurus and Lasionycteris) in North America. Journal of Mammalogy. 84(2):579-593.

Erickson, W., G. Johnson, D. Young, D. Strickland, R. Good, M. Bourassa, K. Bay, and K. Sernka. (2002). Synthesis and comparison of baseline avian and bat use, raptor nesting and mortality information from proposed and existing wind developments. Western EcoSystems Technology, Inc. Prepared for Bonneville Power Administration.

Fiedler, J.K. 2004. Assessment of bat mortality and activity at Buffalo Mountain Windfarm, eastern Tennessee. M.S. Thesis, University of Tennessee, Knoxville.

Fitzgerald, J.P., C.A. Meaney, and D.M. Armstrong. 1994. Mammals of Colorado. University Press of Colorado, Niwot, and Denver Museum of Natural History, Denver.

Gannon, W.L., R.E. Sherwin, and S. Haymond. 2003. On the importance of articulating assumptions when conducting acoustic studies of bats. Wildlife Society Bulletin. 31:4561.

Johnson, D., K. Bay, J. Eddy. 2009. Final Report: Wildlife Baseline Studies for the Dunlap Ranch Wind Resource Area, Carbon County, Wyoming. Western EcoSystems Technology, Inc. Prepared for CH2MHill.

Kunz, T.H., E.B. Arnett, B.A. Cooper, W.P Erickson, R.P. Larkin, T.J. Mabee, M.L Morrison, M.D. Strickland, and J.M. Szewczak. 2007. Assessing impacts of wind-energy development on nocturnally active birds and bats. A guidance document. Journal of Wildlife Management. 71(8):2449-2486

Piaggio, A (Original account by Sherwin, R. 1998) 2005. Species Accounts: Townsend's bigeared bat. Western Bat Working Group. http://www.wbwg.org/speciesinfo/species_accounts/vespertilonidae/coto.pdf

Reynolds, D.S. 2006. Monitoring the potential impact of a wind development site on bats in the Northeast. Journal of Wildlife Management. 70:1219-1227.

Rintz, T. and Bay, K. 2009. Final Report: Wildlife Baseline Studies for the Top of the World Wind Resource Area, Converse County, Wyoming. Western EcoSystems Technology, Inc. Prepared for Duke Energy.

Taylor, K., J. Gruver, and K. Bay. 2008. Wildlife Studies for the Campbell Hill Wind Resource Area, Converse County, Wyoming. Western EcoSystems Technology, Inc. Prepared for Three Buttes Windpower, LLC and Duke Energy.

U.S. Fish and Wildlife Service (USFWS). 2010. Species Listed in Colorado. http://ecos.fws.gov/tess_public/pub/stateListingAndOccurrenceIndividual.jsp?state=CO\& $\underline{\text { s8fid }=112761032792 \& \text { s8fid }=112762573902 \& \text { s8fid }=24012906356871}$ 